LUCIANA DE PAULA

\title{
Narrativas e (Re)significações: uma via de humanização escolar
}

\author{
Versão Corrigida
}




\title{
Narrativas e (Re)significações: uma via de humanização escolar
}

\author{
Versão Corrigida
}

Dissertação apresentada ao Programa PROFLETRAS - Mestrado Profissional em Letras, da Faculdade de Filosofia, Letras e Ciências Humanas da Universidade de São Paulo, como exigência para obtenção do título de Mestra em Letras,

Área de Concentração: Formação de leitores

Orientadora: Prof. ${ }^{\text {a }}$ Dr. ${ }^{\text {a }}$ Maria Zilda da Cunha. 
Autorizo a reprodução e divulgação total ou parcial deste trabalho, por qualquer meio convencional ou eletrônico, para fins de estudo e pesquisa, desde que citada a fonte.

Catalogação na Publicação

Serviço de Biblioteca e Documentação

Faculdade de Filosofia, Letras e Ciências Humanas da Universidade de São Paulo

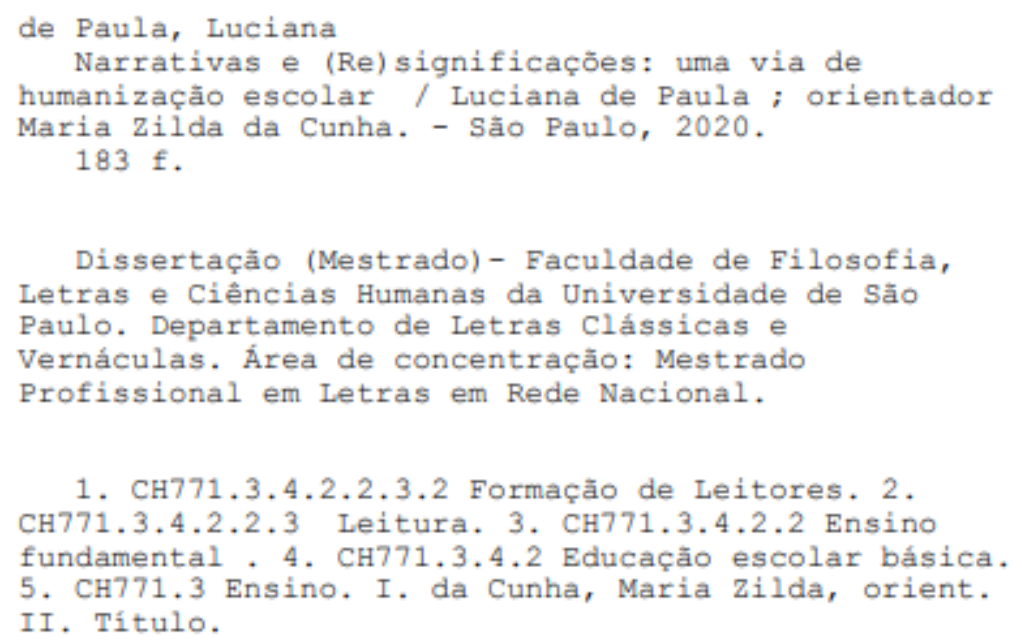

1. CH771.3.4.2.2.3.2 Formação de Leitores. 2 . CH771.3.4.2.2.3 Leitura. 3. CH771.3.4.2.2 Ensino fundamental. 4. CH771.3.4.2 Educaçăo escolar básica. 5. CH771.3 Ensino. I. da Cunha, Maria Zilda, orient. II. Título. 


\section{ENTREGA DO EXEMPLAR CORRIGIDO DA DISSERTAÇÃO/TESE}

\section{$\underline{\text { Termo de Ciência e Concordância do (a) orientador (a) }}$}

Nome do (a) aluno (a): Luciana de Paula

Data da defesa: 19/06/2020

Nome do Prof. (a) orientador (a): MARIA ZILDA DA CUNHA

Nos termos da legislação vigente, declaro ESTAR CIENTE do conteúdo deste EXEMPLAR CORRIGIDO elaborado em atenção às sugestões dos membros da comissão julgadora na sessão de defesa do trabalho, manifestando-me plenamente favorável ao seu encaminhamento e publicação no Portal Digital de Teses da USP.

São Paulo, 15/07/2020

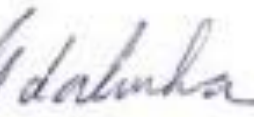


Autora: Luciana de Paula

Título: Narrativas e (Re)significações: uma via de humanização escolar

Orientadora: Prof. ${ }^{a}$ Dr. ${ }^{a}$ Maria Zilda da Cunha

Dissertação apresentada ao Programa PROFLETRAS - Mestrado Profissional em Letras do departamento de Letras Clássicas e Vernáculas da Faculdade de Filosofia, Letras e Ciências Humanas da Universidade de São Paulo, para obtenção do título de Mestra em Letras.

Aprovada em: 19 de junho de 2020

Banca Examinadora

Prof.(a) Dr.(a): Instituição:

Julgamento: Assinatura:

Prof.(a) Dr.(a): Instituição:

Julgamento: Assinatura:

Prof.(a) Dr.(a): Instituição:

Julgamento: Assinatura: 
Uma parte de mim

é só vertigem:

outra parte,

linguagem.

Traduzir-se uma parte

na outra parte

- que é uma questão

de vida ou morte -

será arte?

Ferreira Gullar

Para meus antípodas mais semelhantes Minha trindade estrelar

Do fundo do mar

Maria Helena de Melo de Paula Benedito Roberto de Paula Danilo Roberto de Paula 


\section{Agradecimentos}

Agradeço, imensamente, a toda equipe da E. E. Professora Maria Isabel dos Santos Mello, a família que tão calorosamente me acolheu e me guiou pelos percalços da infinita jornada que é "tornar-se" professora. Agradeço pela atenção na elaboração do horário, nas dispensas tão necessárias, na compreensão pelas minhas ausências e, sobretudo, pelo abraço amigo oferecido nos momentos mais difíceis. À Companhia de Dança Fabinho Vicente, por me fazer esquecer tudo enquanto danço e renovar minhas energias para voltar a encarar o computador. À minha psicóloga, Izabel, por me ajudar a apertar os parafusos de volta no lugar e estar comigo ao longo de minha luta contra a neurose cotidiana. À Rita, Aulus e Ju, minha família de viagens, o por do sol em São Tomé das Letras vai ficar pra sempre na memória. À toda turma PROFLETRAS 2018 pelas trocas valiosíssimas, pelo companheirismo e por todas as risadas. Um agradecimento especial à Viviane, minha companheira de mestrado. À professora Maria Zilda da Cunha, fada madrinha, obrigada pela liberdade. Ao professor Dante Gallian, que tão gentilmente me recebeu em sua Casa Arca quando o presente projeto era apenas um dilúvio de ideias. À tia Lili, tia Nazir e tio Hugo, pelas sonecas na praia, sob a brisa do verão. À família de Paula, pela distância tão necessária e pelo silêncio respeitoso. À minha avó Ana e minha madrinha Zilda, por todas as comidinhas gostosas. Ao meu tio Antônio por todos os cortes de cabelo adoráveis. E, calorosa, humana e narrativamente, a cada um dos meus alunos, sem os quais nada disso seria possível: "Somos do mesmo sangue tu e eu" - Rudyard Kipling.

Este trabalho contou com o apoio da CAPES, código de financiamento 001. 


\section{Resumo}

DE PAULA, Luciana. Narrativas e (Re)significações: uma via de humanização escolar. 2020. 183 f. Dissertação (PROFLETRAS - Mestrado Profissional em Letras) Faculdade de Filosofia, Letras e Ciências Humanas, Universidade de São Paulo, São Paulo, 2020.

O presente estudo tenciona perseguir e adaptar uma específica via metodológica, o LabLei, para o trato com o texto artístico literário narrativo na sala de aula, lançando bases para uma tentativa de implementação de um movimento de humanização no ambiente escolar. Por uma perspectiva mais objetiva, tenciona-se alargar os horizontes humanísticos dos alunos envolvidos através da realização de uma intervenção pedagógica que, além de um mero exercício intelectual, promova uma possibilidade de reflexão através do texto não como objeto escolarizado, mas como objeto artístico, em torno de questões humanas em suas dimensões afetivas, intelectivas e volitivas, contribuindo para o autoconhecimento e o conhecimento do outro. Ao final de todo um percurso pedagógico e reflexivo, pôde-se constatar que o uso da leitura literária de textos narrativos é eficaz para o trato com a humanização em suas perspectivas relativas à significação e/ou simbolização, memória, empatia, fruição, abertura valorativa, empoderamento, legitimação, etc. Em termos gerais, o presente estudo trata da investigação e estabelecimento de uma via, dentre muitas outras, para o tão necessário movimento de humanização da instituição escolar.

Palavras-chave: Formação de Leitores. Leitura Literária. Narrativa. Humanização. 


\begin{abstract}
DE PAULA, Luciana. Narratives and (Re)significations: a path to school humanization. 2020. 183 f. Dissertação (PROFLETRAS - Mestrado Profissional em Letras) - Faculdade de Filosofia, Letras e Ciências Humanas, Universidade de São Paulo, São Paulo, 2020.

This study intends to pursue and adapt a specific methodological approach, LabLei, to deal with the narrative literary artistic text in the classroom, laying the foundations for an attempt to implement a humanization movement in the school environment. From an objective perspective it is intended to broaden the humanistic horizons of the students involved through the realization of a pedagogical intervention that, besides a mere intellectual exercise, promotes a possibility of reflection through the text not as a schooled object, but as an artistic object, around human issues in their affective, intellectual and volitional dimensions, contributing to the self-knowledge and knowledge of the other. At the end of a pedagogical and reflective course, it was found that the use of literary reading of narrative texts is effective for dealing with humanization in its perspectives related to meaning and/or symbolization, memory, empathy, enjoyment, openness of value, empowerment, legitimation, etc. In general terms, this study deals with the investigation and establishment of a path, among many others, for the much needed humanization movement of the school institution.
\end{abstract}

Keywords: Reader Training. Literary reading. Narrative. Humanization. 


\section{Lista de Tabelas}

Tabela 1 - Ideias dos alunos acerca do personagem Gigante.

81

Tabela 2 - Cronograma de aplicação das etapas da intervenção pedagógica.

Tabela 3 - Manifestação dos alunos nas Histórias de Leitura para serem usadas no Itinerário de Discussão.

Tabela 4 - Ideias dos alunos acerca do personagem Gigante (em construção).

Tabela 5 - Ideias dos alunos acerca do personagem Gigante (completa).

Tabela 6 - Estudo de síntese lexical acerca da intervenção pedagógica aplicada..... 105 


\section{Sumário}

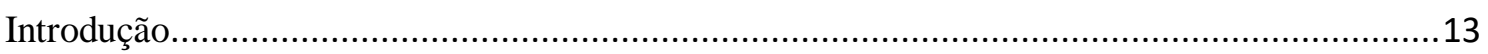

1. Algumas Considerações Iniciais Sobre a Narrativa .............................................................16

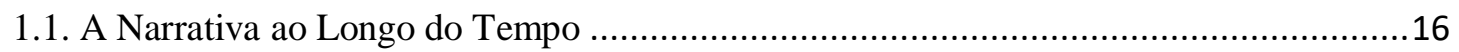

1.1.1. A Era Clássica, os Poemas Épicos e as Fábulas ....................................................16

1.1.2. A Épica do Povo Hebreu e as Narrativas Bíblicas.................................................22

1.1.3. A Idade Média e a Narrativa Medieval Tradicional ..............................................27

1.1.4. A Pos-Medievalidade e o Romance ...................................................................... 31

1.1.5. A Narrativa na Contemporaneidade ……............................................................. 36

1.2. A Narrativa, Seus Elementos Constitutivos e Suas Relações ...........................................43

1.2.1. Aspectos Estruturais Iniciais ………………..................................................... 43

1.2.2. A Narratividade como Forma de Pensamento .........................................................45

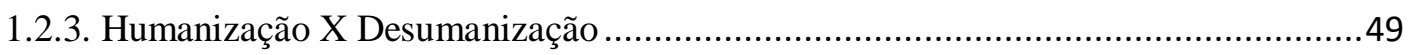

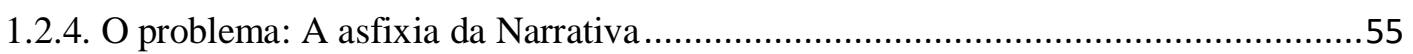

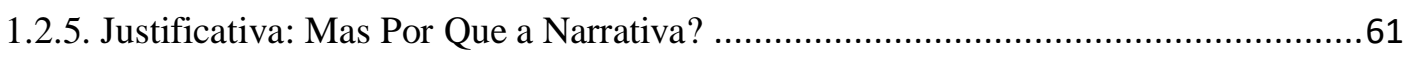

2. Metodologia e Proposta de Intervenção Pedagógica...........................................................66

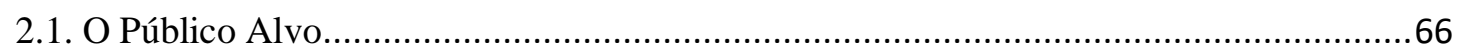

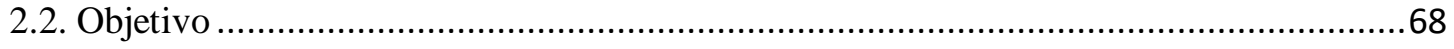

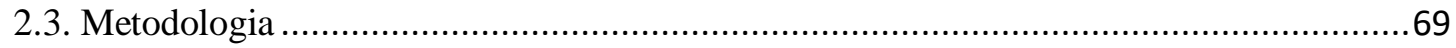

2.3.1. A Reunião de Apresentação ................................................................................69

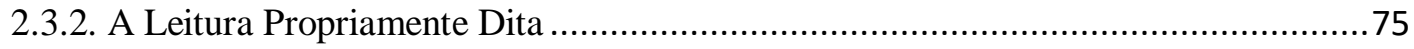

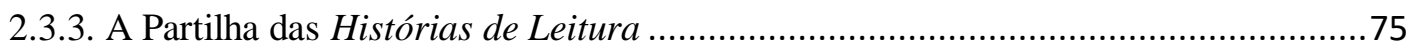

2.3.4. A Realização do Itinerário de Discussão............................................................76

2.3.5. A Partilha das Histórias de Convivência ...............................................................77

2.3.6. Método LabLei sem o clássico, seria possível? .................................................... 78

2.4. Proposta de Intervenção Pedagógica ......................................................................... 85

2.4.1. $1^{\text {a }}$ Etapa: Apresentação da Atividade …………...................................................... 85

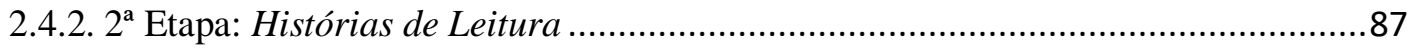

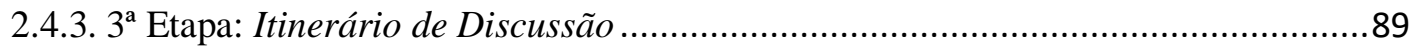

2.4.4. $4^{\mathrm{a}}$ Etapa: Histórias de Convivência ..................................................................90 
2.4.5. Cronograma de realização

3. Descrição das Etapas de Intervenção Pedagógica Desenvolvidas e Análise dos Resultados ..92

3.1. 1. . Etapa: Apresentação da Atividade. .92

3.2. $2^{\text {a }}$ Etapa: Histórias de Leitura …..............................................................................93

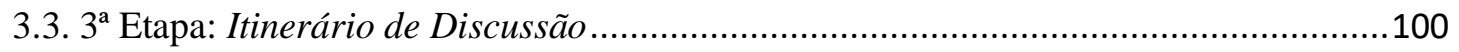

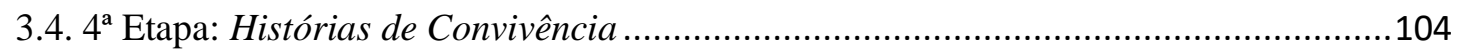

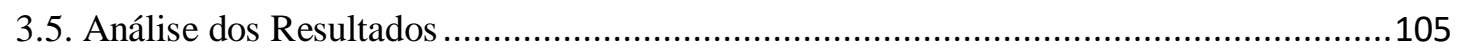

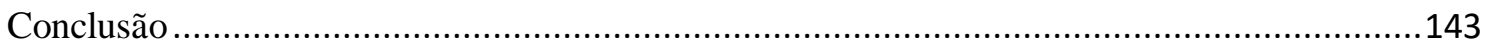

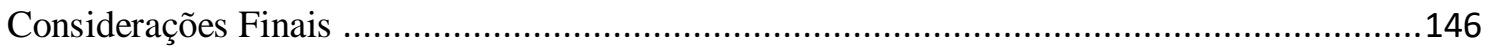

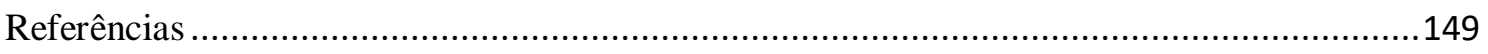

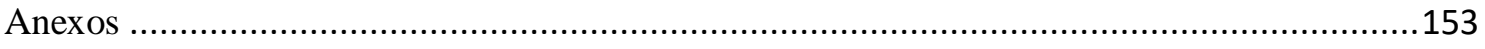

Anexo A - Conto utilizado na intervenção....................................................................153

Anexo B - Diários de Leitura selecionados para análise...................................................157 


\section{Introdução}

Narrativas. Talvez o gênero mais direto a capturar o fluxo de tempo concedido a nós, humanos, no qual agimos, erramos, aprendemos, amadurecemos, mudamos. A narrativa registra e resgata humanidade em movimento, em vida. Narrar é reviver, é repensar, imaginar, é ordenar a vida passada em pontos de ancoragem sobre os quais nos apoiamos para projetarmo-nos em direção ao futuro. Diremos com Guimarães Rosa, assim como a vida, narrativas são travessia.

Nas vias de fluxo dos gêneros narrativos, dois traços, dentre muitos outros, se farão notar com maior labor no presente estudo: o aspecto figurativo e a narratividade.

Figurar, como se verá com maior propriedade a seguir, é a possibilidade que possui a narrativa de tratar de elementos abstratos de forma mais concreta, através de um acontecimento ou um ato. $\mathrm{O}$ discurso figurativo atribui maior tangibilidade a grandezas que, por alguma aresta cognitiva, ainda nos escapam, necessitando de um processo e/ou uma vivência para serem compreendidas de forma um pouco mais efetiva.

A narratividade é a forma cognoscente através da qual o discurso figurativo se apresenta. Trata-se da estrutura equilíbrio-instabilidade-(r)equilíbrio que busca abarcar o processo vivido que, por sua vez, trará à tona a grandeza abstrata a ser considerada.

A associação do caráter figurativo com a narratividade permite ao gênero narrativo infinitas possibilidades temáticas, conjugando extremos desde a grandiosa abstração mais complexa até a menor das vivências que condensam em si, fractalmente, a proporção infinita.

Para além das riquíssimas possibilidades temáticas e da magia ao transpor o abstrato ao concreto e o pequeno ao grandioso, a narrativa possui ainda a capacidade humana por excelência de "nomear" ${ }^{1}$, de atribuir corpo significativo àquilo que se sente ou se pensa, em outras palavras, a narrativa é capaz de significar.

Reunindo, assim, os atributos de nomeação, figuração e narratividade, a narrativa mostra-se como uma via importante quando a questão é a humanização. Entendida não como conceito estático, mas como processo, a humanização também contempla em si, de forma constitutiva, o fluxo abarcado pela narratividade, a figuração e a nomeação.

\footnotetext{
${ }^{1}$ A princípio, será usada a palavra "nomear" para se tratar da tradução de um elemento humano em expressão. Com o desenvolvimento do estudo, observar-se-á que esse "nomear" é algo que vai além do ato de dar nome a algo, ele implica um desenvolvimento narrativo, uma transformação ao longo do tempo.
} 
Não é por uma grande coincidência que cada um dos povos que se organizou sobre a face da Terra teve, como baluarte de sua identidade e de sua condição enquanto ser humano, uma narrativa fundadora.

A observação do uso das narrativas como elementos constitutivos da representação humana ao longo do tempo é assunto do primeiro capítulo do presente estudo que, através de um breve panorama histórico, busca perseguir a trilha da tradução da condição humana na organização das narrativas mais representativas para a cultura ocidental em cada período.

Da milenar aliança firmada entre a humanização e os gêneros narrativos, passemos aos nossos tempos. A contemporaneidade, por uma série de elementos seus constitutivos tais como a sinergia do tecnológico com o arcaico e a retomada visceral da informação e do neotribalismo, tem colocado, de forma cada vez mais frequente e preocupante, a questão do vazio de significação e, por consequência, da desumanização. O campo de observação central de tal condição para o presente estudo é a realidade escolar tanto mais vazia e ineficaz quanto desumana e violenta.

Considerando a instituição escolar como um ambiente de desumanização e entendendo o contato com a narrativa como uma possível via de humanização, a hipótese inicial sobre a qual se orienta o presente estudo é a de que a aproximação apropriada do gênero em questão pode proporcionar algo como um início de busca, uma inquietação que alerte o interlocutor do processo, os alunos no caso, para a importância do desenvolvimento humano, ou seja, da humanização.

A hipótese elaborada conduz, invariavelmente, à busca por um método, uma maneira de apresentar a narrativa de forma diferenciada, que desperte no aluno a inquietação almejada. Surge então a pergunta: como utilizar a narrativa para a ampliação do horizonte interpretativo, criativo e fruitivo, alavancando as possibilidades de formação emocional, social e humana no ambiente escolar?

Parte da resposta veio com a metodologia desenvolvida pelo professor doutor Dante Gallian: o LabLei. Trata-se de uma metodologia desenvolvida ao longo de quinze anos com os alunos da Escola Paulista de Medicina - UNIFESP e trabalhadores do meio corporativo empresarial, cujo objetivo principal era proporcionar algo como um "curso de humanização" através da leitura de obras literárias clássicas.

Toda a descrição do método LabLei, sua adaptação para os alunos de nono ano da escola estadual e a elaboração de uma intervenção pedagógica a ser aplicada é objeto de registro e reflexão do segundo capítulo. 
Com a adaptação do método e a elaboração da intervenção pedagógica realizadas, delineou-se com maior clareza o objetivo específico do presente estudo. Por mais que, por uma perspectiva um pouco mais geral, fosse claro, desde o princípio, que o presente estudo tenciona perseguir e adaptar uma específica via metodológica para o trato com o texto artístico literário, lançando bases para uma tentativa de implementação de um movimento de humanização no ambiente escolar, faltava algo mais imediato. Foi apenas com a adaptação do método que se chegou ao objetivo mais específico que busca alargar os horizontes humanísticos dos alunos envolvidos através da realização de uma intervenção pedagógica que, além de um mero exercício intelectual, promova uma possibilidade de reflexão através do texto não como objeto escolarizado, mas como objeto artístico, em torno de questões humanas em suas dimensões afetivas, intelectivas e volitivas, contribuindo para o autoconhecimento e o conhecimento do outro, condições fundamentais para a construção de uma sociedade mais respeitosa e humana frente aos desafios impostos pelo discurso do ódio, pela segregação e pela polarização.

Com os objetivos bem delineados e a intervenção pedagógica elaborada, partimos para o campo de pesquisa: a sala de aula. Os planos iniciais foram sendo aplicados e cada uma das etapas foi descrita no terceiro capítulo. Além dessa descrição da intervenção realizada, o terceiro capítulo também conta com uma análise que busca evidenciar o alcance e a profundidade das possibilidades oferecidas pelo trato da humanização através da leitura e da partilha das experiências de leitura no ambiente escolar. A análise teve o seu ponto de partida em um corpus formado pelos Diários de Leitura, anotações de cunho subjetivo, elaboradas pelos alunos envolvidos em cada uma das etapas organizadas na intervenção.

Repletos de uma atmosfera emotivo-reflexiva, os Diários vieram não penas servir de objeto de observação, mas, sobretudo, atribuíram ao presente estudo um veio sanguíneo quente e vivo, conduzindo vida ao trabalho que respira orgânica e subliminarmente à leitura. Os Diários constantes nessa dissertação são o traço humano da presença de cada um dos meus alunos, sem os quais nada disso seria possível. 


\section{Algumas Considerações Iniciais Sobre a Narrativa}

Iniciemos o presente estudo acerca da narrativa perseguindo dois caminhos principais: uma via histórica e uma via constitutiva.

A via histórica busca construir um entendimento inicial acerca da origem de características de nossos tempos presentes, dado que o presente é a culminância última de causas enraizadas no passado. Além disso, o olhar histórico proporciona uma interessante situação especular na medida em que estabelece uma perspectiva narrativa sobre a própria narrativa.

De modo complementar, a via constitutiva busca lançar um entendimento inicial sobre algumas características da narrativa enquanto gênero, estrutura cognoscente e meio de humanização, refletindo acerca do fenômeno da perda da capacidade de significar através da asfixia da narrativa.

\subsection{A Narrativa ao Longo do Tempo}

[...] é bom que, por humildade, saibamos voltar ao "húmus" a partir do qual se moldou o que é "humano".

Michel Maffesoli

$\mathrm{Na}$ tentativa de abarcar as vias de fluxo através das quais o homem ocidental traduziu a sua essência, o seu vir a ser, em formato narrativo, iniciemos o presente percurso histórico, focalizando, mesmo que de modo inicial, a história da narrativa, seus meandros ao longo do tempo e suas especificações.

\subsubsection{A Era Clássica, os Poemas Épicos e as Fábulas}

Ao focalizar a civilização grega antiga, observa-se que esta, dentre tantas outras, também se valeu do gênero épico narrativo para o registro de seus valores e dos grandes feitos de suas ilustres personalidades. O grande arcabouço que conserva tais valores até 
os dias atuais são os grandiosos poemas narrativos reunidos sobre a autoria de Homero: Ilíada e Odisseia.

Embora organizados sob a autoria de Homero, tais cantos representam, na realidade, a reunião de grande parte da memória grega antiga, fruto da composição de um número desconhecido de poetas-cantores: os aedos. Estes compunham cantos com ritmo e métrica bem definidos. No caso da poesia épica grega, o formato característico é o hexâmetro dactílico, geralmente acompanhado por instrumentos tais como a lira, o fórminx e a cítara. $\mathrm{O}$ hexâmetro dactílico é fundamental não apenas para assinalar a identidade específica da poesia épica grega, mas também para ajudar na memorização para a reprodução dos poemas em um contexto de tradição oral, no qual o aedo realiza seu canto na presença de seus interlocutores, ou seja, no mesmo espaço físico e temporal.

O registro e a passagem dos valores gregos da época foram realizados, não através de um conjunto de técnicas, recomendações ou prescrições, mas através dos poemas épicos e, sobretudo, através do forte e basilar eixo narrativo empreendido em tais poemas. É através do acompanhamento dos atos de Aquiles, Odisseu e outros, no desenvolvimento cronológico do poema, que se compreende e se absorve os valores propostos. Jaeger afirma que “[...] a história da educação grega coincide substancialmente com a da literatura. Esta é, no sentido originário que lhe deram seus criadores, a expressão do processo de autoformação do homem grego" (JAEGER, 1995, p. 19).

Considerando a formação, o homem clássico perseguia dois ideais principais: a arete e o ethos.

A arete tratava-se da conjugação entre a ação e a nobreza de espírito, a realização de grandes feitos que testemunha a honra e o heroísmo do homem clássico. Esses grandes feitos estão sempre associados à semântica guerreira, são os atos de coragem e de desprendimento de si diante da situação de conflito que vão construir a grandiosa imagem de honra sobre a qual se busca edificar a imagem de si. De acordo com Jaeger, "[...] o velho conceito de arete [...] trazia uma nova imagem do Homem perfeito, para qual ao lado da ação estava a nobreza do espírito, e só na união de ambas se encontrava o verdadeiro objetivo." (JAEGER, 1995, p. 30).

A arete conservava em si algo de cavalheiresco, relativo à nobreza e aos seus feitos em tempos de guerra. Com a chegada de tempos mais pacíficos, o valor associado 
aos grandes feitos nas guerras sede espaço à nobreza exercida em tempos de paz: o ethos.

O ethos consistia em um refino primoroso nas relações interpessoais, uma cortesia sem precedentes, que refletia a grandiosidade do homem grego. Segundo Jaeger, "Nobres ou plebeus, todos os membros desta sociedade conservam o distintivo comum do decoro em todas as situações" (JAEGER, 1995, p. 43).

Vê-se então que, sob o ponto de vista da narrativa, Ilíada versa sobre o ideal do homem grego em situação de guerra, enquanto Odisseia trata do mesmo ideal em tempos de paz. Jaeger, em relação ao contexto sobre o qual versa a Ilíada, afirma:

O mais antigo dos dois poemas mostra-nos o predomínio absoluto do estado de guerra, tal como deveria ser no tempo das grandes migrações gregas. A Ilíada fala-nos de um mundo situado num tempo em que domina exclusivamente o espírito heroico da arete, e corporifica este ideal em todos os seus heróis. Junta numa unidade ideal indissolúvel a imagem tradicional dos antigos heróis, transmitidas pelas sagas e incorporadas aos cantos, e as tradições vivas da aristocracia do seu tempo, que já conhece a vida organizada da cidade, como provam principalmente as pinturas de Heitor e dos Troianos (JAEGER, 1995, p. 40).

Além do contexto de guerra, a Ilíada também traz aspectos urbanos bastante evidentes na descrição de Troia, o que dificulta a datação da obra. Ao mesmo tempo em que se pode situar o poema no período das grandes migrações, pode-se também atribuirlhe algo posterior, relativo ao estabelecimento da polis grega.

Ao retratar a guerra e elementos referentes a polis, pode-se considerar que o poema retrata a conduta do homem grego ideal no ambiente público, em suas realizações diante do outro no ambiente comum, na ágora da polis ou no campo de batalha.

Sobre o cenário no qual se desenrola a Odisseia, o mesmo autor considera:

A Odisseia oferece-nos outro quadro. O motivo do regresso do herói, o
nostos, que se liga de modo tão natural à guerra de Tróia, conduz à
representação intuitiva e à terna descrição da sua vida na paz. Estes cantos
são, em si, antiquíssimos. Contudo, era para o lado humano da vida dos
heróis que se dirigia, de preferência, o interesse de uma época posterior, cujo
sentir se alheava das descrições sangrentas de batalhas e experimentava a
necessidade de refletir a sua própria vida nos destinos e nas personagens das
velhas sagas (JAEGER, 1995, p. 41).

Muito embora também seja possível considerar a Odisseia como retratando a conduta do homem grego ideal no ambiente público, na sua jornada de volta para a casa 
ao fim da guerra, a Odisseia introduz um elemento que, posteriormente, vai alterar profundamente o enfoque sobre a situação na qual se dá o encontro do interlocutor com a obra: a casa, o ambiente privado. Não se pode dizer que, na Odisseia, o trato referente à casa já demonstre uma tendência à fragmentação do indivíduo de sua comunidade e seu refúgio na realidade privada como se apresentará na pós-medievalidade, pois toda a formação do homem grego é orientada para o serviço da comunidade:

Todo o futuro humanismo deve estar essencialmente orientado para o fato fundamental de toda a educação grega, a saber: que a humanidade, o "ser do Homem" se encontrava essencialmente vinculado às características do Homem como ser político. O fato de os homens mais importantes da Grécia se considerarem sempre a serviço da comunidade é índice da íntima conexão que com ela tem a vida espiritual criadora (JAEGER, 1995, p. 17, grifo nosso).

É justamente o tempo de paz que orientou o homem grego à reflexão, à tarefa contemplativa que vai culminar com o aparecimento da filosofia que, por mais que se dê através de um processo de pensamento individual, realizava-se na ágora através do gênero diálogo, ou seja, implicava o encontro com o interlocutor no ambiente público.

Mesmo reconhecendo o valor da filosofia, Jaeger (1995) observa algo como certa supremacia formadora da narrativa sobre a filosofia tanto por um viés temporal quanto por sua acessibilidade, validade universal e plenitude imediata e viva. Nas palavras de Jaeger:

[...] os valores mais elevados ganham, em geral, por meio da expressão artística, significado permanente e força emocional capaz de mover os homens. A arte (narrativa) tem um poder ilimitado de conversão espiritual. É o que os gregos chamam de psicagogia. Só ela possui ao mesmo tempo a validade universal e a plenitude imediata e viva, que são as condições mais importantes da ação educativa. Pela união dessas duas modalidades de ação espiritual, ela supera ao mesmo tempo a vida real e a reflexão filosófica. A vida possui a plenitude de sentido, mas as suas experiências carecem de valor universal [...]. A filosofia e a reflexão atingem a universalidade e penetram na essência das coisas. Mas atuam somente naqueles cujos pensamentos chegam a adquirir a intensidade de uma vivência pessoal. Daqui resulta que a poesia tem vantagem sobre qualquer ensino intelectual e verdade racional, assim como sobre as meras experiências acidentais da vida do indivíduo. É mais filosófica que a vida real (se nos é lícito ampliar o sentido de uma conhecida frase de Aristóteles), mas é, ao mesmo tempo, pela concentração de sua realidade espiritual, mais vital que o conhecimento filosófico (JAEGER, 1995, p. 63. Grifo nosso)

Além de conservar em si os valores basilares à concepção do ideal de homem grego, a narrativa possui ainda certa magia, um caráter anímico capaz de desencadear 
um fascínio e de mover seu interlocutor no sentido de ir à busca de determinada imagem, conduta e concepções ideais. Aí está o maior valor da narrativa, o que Jaeger defende como exercendo certa superação quando contraposta à reflexão filosófica, meramente contemplativa, reflexiva e abstrata, o que, sem dúvida, acaba por afastar vasta gama de interlocutores para quem isto não é o suficiente para atingir o cerne da essência humana, a profundeza dos desejos e das paixões. Nesse sentido, a narrativa é bem mais atraente e vital, falando ao âmago da alma humana e despertando sonhos.

Esse feroz potencial anímico, próprio e fundamentalmente característico da narrativa, emprenha todos os seus elementos de uma vida irresistível. Daí o seu fortíssimo caráter exemplar. Cada um dos personagens é investido de uma aura encantadora, produzindo, no interlocutor da obra, uma atração inevitável que resulta na incorporação do paradigma. Jaeger considera que:

\footnotetext{
"A tradição das antigas sagas oferece-nos exemplos vivos desta educação; não apenas figuras de vigor e esforço, mas também homens em cujo sangue passa a corrente viva da experiência, cada vez mais profunda, de uma antiga dignidade renovada dia a dia" (JAEGER, 1995, p. 52).
}

Muito embora o interlocutor maior de toda essa possibilidade formativa relativa aos poemas homéricos sejam os integrantes da nobreza, o poema épico de Hesíodo, Os trabalhos e os dias, apresenta como interlocutor mais comum os trabalhadores camponeses, a base da sociedade grega de então, afirmando que nem só de glórias em campo de batalha ou de cortesia vivia a sociedade grega.

Sob o ponto de vista de sua temática, Os trabalhos e os dias, concentra um apanhado de recomendações práticas para a realização do trabalho camponês seja na agricultura, seja em alto mar. Sua primeira parte traz as narrativas míticas de Prometeu, Pandora e a fábula $O$ gavião e o rouxinol com o intuito de justificar sua segunda parte, a qual traz conselhos práticos, calendários para o trato com o plantio, a colheita e as marés.

Mesmo reconhecendo Os trabalhos e os dias como um conjunto de narrativas fundamentais para entender a maior parte da sociedade grega clássica, ele não tem o mesmo vulto que Ilíada e Odisseia para a compreensão da cultura ocidental contemporânea. No entanto, algo nele é importante de ser mencionado: a fábula.

A fábula se disseminava através da modalidade falada, não contando com a forma fixa do hexâmetro dactílico nem com o ritmo dos cantos da epopeia. A fábula se 
constitui em forma de prosa, a qual cada um modificava ao sabor do momento em que se contava.

Fábula e epopeia conservam em comum o valor no sentido de disseminar um caráter formativo; no entanto, a fábula está mais associada a elementos cotidianos, relacionados à rotina campesina, sem a grandiosidade e pompa dada ao trato com os valores das camadas mais abastadas.

Além do tom bem mais comedido, o que há de fundamental na fábula é um elemento novo, também com intenções instrutivas: a moral, uma máxima que buscava sintetizar toda a narrativa em algo como uma lição central. Tal lição funcionava como rédea interpretativa que orientava e delimitava as possibilidades de reflexão do interlocutor em torno do enredo desenvolvido.

É interessante observar que os cantos épicos, que tinham como interlocutores a elite de então, eram livres para serem explorados em seu potencial interpretativo ${ }^{2}$, em suas possibilidades verticais de consideração, já a fábula parece exercer certa pressão ideológica sobre os trabalhadores camponeses ao vir com uma interpretação pronta. Estaria, desde a idade clássica, a possibilidade de reflexão em torno da forma artística narrativa reservada à elite?

Assim sendo, observa-se que a era clássica foi prodigiosa na utilização de gêneros narrativos orais em seu caráter formativo. De acordo com Jaeger, o gênero épico foi o gênero que mais se adequou às necessidades comunicativas desse período da história humana uma vez que o eixo narrativo proporcionava um aspecto figurativo e exemplar no trato de valores abstratos, o tom magnânimo atribuía a grandiosidade e o esplendor necessários aos valores e aos feitos tratados, a métrica, o ritmo e o desenvolvimento de ações numa cronologia mais ou menos linear ajudavam na realização oral e na memorização em um momento em que a escrita não era do domínio da maioria das pessoas. Observou-se também a importância da oralidade na realização dessas narrativas no sentido de aproximar as pessoas em um mesmo espaço físico e temporal. Todas essas características relativas à narrativa épica vinham envoltas por uma atmosfera anímica mágica que seduzia o interlocutor no sentido de buscar e incorporar

\footnotetext{
${ }^{2}$ Mesmo com o empecilho da interpretação imediata e do exercício de possíveis conduções interpretativas realizadas pelo aedo na realização dos cantos (como será mencionado mais adiante, no trato com a escrita), Ilíada e Odisseia não apresentam nenhum elemento que conduza à reflexão da obra de forma tão incisiva quanto a moral das fábulas.
} 
os valores expressos. A fábula, embora também se trate de uma organização narrativa destinada à função instrutiva, não conta com os aspectos formais e rítmicos da poesia épica. A fábula vinha sempre acompanhada pela moral, uma máxima de valor instrutivo que concentra em si um ensinamento com pretensões de significado central e total da narrativa.

\subsubsection{A Épica do Povo Hebreu e as Narrativas Bíblicas}

Conjuntamente e em igual importância à influência grega, outro domínio cultural atuou sobre o nascimento da era contemporânea: o discurso bíblico.

O conjunto de narrativas que formou a Torá, o livro sagrado dos hebreus, e o Antigo Testamento Bíblico teve sua origem no Pentateuco, do grego "cinco rolos". Tratava-se do registro escrito dos livros do Gênesis, Êxodo, Levíticos, Números e Deuteronômio.

Muito embora trate-se do Pentateuco como um registro escrito, sua origem é devida à tradição oral, é somente a partir de 1200 a. C. que ele passa a ser transcrito. Dados mais específicos sobre a escrita e a disseminação de tais textos são extremamente escassos e duvidosos. Alguns, como os membros da religião judaica e os cristãos, atribuem a autoria ao próprio Moises, outros, como o estudioso bíblico Julius Wellhausen em sua obra Prolegomena to the History of Israel (1883), consideram a possibilidade de que outros tenham registrado a tradição hebraica nas narrativas do Pentateuco. De qualquer forma, é esse o momento histórico no qual a escrita aparece de forma determinante.

O aparecimento das religiões monoteístas está fortemente atrelado ao uso da escrita, tanto que aos povos monoteístas é dada a alcunha de Povos do Livro. Por mais que a poesia oralizada tenha sobre a prosa uma supremacia cronológica, ela depende da presença dos interlocutores em um mesmo espaço físico e temporal. A interação face a face proporciona o maior grau de interação possível entre interlocutores, no entanto, embora a escrita tenha resultado certo distanciamento, ela trouxe grandes vantagens:

Na mídia da transmissão oral repousa a memória cultural da sociedade e da forma segura da repetição, nos ritos e festas da atualização coletiva do extra cotidiano; na mídia da escrita a memória cultural se emancipa das obrigações da repetição e da expectativa coletiva e abre-se ao novo e ao indivíduo. O específico da literatura não repousa nas formas da língua, no formal, na beleza da linguagem e da fundamentação linguística formal: tudo isto é meio 
do qual se serve a memória para estabilização e transmissão. O específico da literatura repousa antes de tudo na inovação, no individual, na emancipação. Para isto ela precisa da escritura: para fazer ir além do que é dado e fazer valer o individual, o não-coletivo, o não-ouvido (MAGALHÃES, 2008, p. 04, grifo nosso).

A revolucionária instituição da escrita para o registro das narrativas permitiu a independência do leitor sobre o autor da obra, não apenas no sentido de entrar em contato com a obra no mesmo espaço físico e temporal do autor ou daquele que a executa, mas também no sentido de que, ao entrar em contato com a obra sozinho, o leitor ganha a autonomia de refletir sobre ela sem possíveis conduções realizadas pelo autor na interação face a face. Agora, as obras estão livres da supremacia de seus autores e/ou aedos e se transmutam em uma realidade de infinitas interpretações resultantes do contato com cada um de seus leitores. Obviamente, essa não é uma realidade total, haja vista o fato de que a escrita era um processo extremamente caro e a grande maioria da população ainda não dominava o código do aramaico, hebraico ou do grego para a leitura. Mesmo reconhecendo, no momento observado, o início de uma revolução, ela é ainda bastante incipiente, sendo encerrada nos domínios religiosos das sinagogas.

Embora a escrita represente certa ruptura com a interação face a face, o maior grau de interação possível, a autonomia trazida por ela é algo extremamente emancipatório e produtivo, que responde singularmente a tal desvantagem. No entanto, a leitura do Pentateuco, embora servisse para o estudo individual dos sacerdotes, tinha seu uso mais comum através da realização oral, no culto realizado nas sinagogas, onde o sacerdote lia alguma passagem aos presentes e explicava-as, com base numa interpretação canônica, advinda da instituição mosaica. Observe que, por mais que já seja possível especular em torno de uma revolução empreendida pelo uso da escrita, através da emancipação individual diante da leitura e reflexão autônomas, essa revolução é extremamente incipiente, o contexto mais comum de realização da escrita ainda conserva características mais próximas à realização oral dos aedos gregos e assim continuará ao longo de toda a idade média. A promissora revolução da leitura só chegará a tomar contornos reais na modernidade, com o advento da imprensa, e, ainda assim, não chegará a se consumir como uma realidade total. Se julgarmos o atual panorama educacional brasileiro e os níveis de analfabetismo, pode-se afirmar, sem exagero, que a emancipação individual diante da leitura ainda não aconteceu para grande parte das camadas populares, sobretudo em regiões de elevada carestia. 
Da independência proporcionada pela escrita no processo de reflexão intelectual advém ainda o uso proclamativo, algo como uma brecha interativa para que o leitor atribua novos sentidos à narrativa sucintamente desenvolvida com o intuito de conjugar a narrativa com sentidos resultantes da experiência prévia do leitor, exercendo assim maior identidade entre a própria vida e o enredo apreciado. No uso proclamativo, "a vida humana se torna a aventura aberta do pensamento e da narrativa" (MAGALHÃES, 2008, p. 04)

Ainda acerca do uso proclamativo e, na esteira de Northrop Frye, Magalhães irá refletir:

\begin{abstract}
A divisão estabelecida por Frye, teórico literário, sobre os usos da linguagem, o uso poético, o uso alegórico e o descritivo, defende que na Bíblia temos um novo uso: o proclamativo, o que caracterizaria a intensidade das tramas e personagens, tendo como objetivo incluir o leitor nos temas, nas opções das personagens, em seus dilemas éticos. O texto seria, portanto, sucinto porque caracterizado por um grande apelo a que o leitor crie a sua própria história a partir da história contada. (MAGALHÃES, 2008, p. 03).
\end{abstract}

A união do uso proclamativo com o caráter anímico, próprio da narrativa épica hebraica, confere, à narrativa bíblica, um poder de formação e reflexão sem precedentes. Além da energia vital, a narrativa bíblica ainda conta com um espaço para que tal energia traga à luz elaborações individuais, conduzindo a estratégia formadora da narrativa ao patamar da ação, da realização intelectual do leitor. Há uma passagem determinante do interlocutor grego, que recebia uma formação advinda de uma narrativa pronta, para o leitor hebreu que, além de receber a formação, tinha espaço para a interpretação que poderia vir a dar a luz um novo sentido, um novo significado. Eis aí, no conceito de uso proclamativo, as bases para o desenvolvimento dos conceitos de polifonia da leitura e de ressignificação no trato com a narrativa ${ }^{3}$.

Mesmo com essa abertura interpretativa em relação ao uso proclamativo, a instituição dos códices, a substituição do rolo pelo bloco de folhas de pergaminho costuradas, acabou por colocar algumas limitações, resultantes da necessidade de organização da escrita. Tais limitações consistem na instituição de homogeneidade e linearidade do espaço e do tempo, além de lançar bases para o surgimento de uma gramática resultante do uso visual de um alfabeto fonético.

\footnotetext{
${ }^{3}$ Os conceitos de polifonia da leitura e de ressignificação serão definidos a seguir, no subtítulo Narratividade como forma de pensamento.
} 
Por uma perspectiva temática, a narrativa épica hebraica e, por extensão, os códices narrativos que compõem o Antigo Testamento Bíblico, são extremamente ricos. Porém, em meio a essa riqueza, algo é central: o repúdio à idolatria. Surge, diante do panteão grego e de outras culturas politeístas, a afirmação de um único Deus, soberano de toda a criação, o alfa e o ômega, o princípio e o fim de toda a existência. Um Deus que não pode ser representado em imagem e não admite o culto a nenhum tipo de representação feita por mãos humanas. O debate em torno da significação e da interdição ao uso de representações é extenso e acalorado, porém, Hans-Peter Schmidt ${ }^{4}$, em citação de Antônio Magalhães, afirma que "vê o sentido de proibição de imagem não na frase: 'Não deves fazer imagem para ti', porque nos é impossível uma verdade sem imagens, mas no sentido, 'tu não deves ver o quadro como a coisa em si", (SCHMIDT apud MAGALHÃES, 2008, p. 05).

Ao entender que não se deve considerar o quadro, a representação, como o algo em si, observa-se a relação existente na representação que o significante faz do significado, como é próprio do signo linguístico e, portanto, da escrita. As narrativas hebraicas são a gênese de uma narrativa que conserva em si, de maneira especular, o domínio da representação, seja na concepção de Deus, seja no uso da escrita, um sistema de representação complexo que encerra o mistério do signo que não é, em si, a totalidade do objeto, da ideia que representa.

Além da complexidade da representação sígnica e/ou simbólica, a concepção de um Deus único trouxe uma série de implicações sobre o pensamento de então. A principal delas é, sem dúvida, o desenvolvimento de uma tendência na qual Deus representa o bem supremo e, a negação de Deus, o mal absoluto. Mesmo que tal maniqueísmo perdure até os dias atuais e já tenha sido usado para justificar episódios terríveis da história da humanidade, esse constructo tende a desaparecer diante das narrativas fundadoras presentes no Novo Testamento.

O Antigo Testamento, além dos já mencionados cinco livros do Pentateuco, é formado ainda pelos dezesseis Livros Históricos, que conservam a história dos hebreus em busca das terras de Canaã, a formação do povo judeu e do atual estado de Israel; os sete Livros Poéticos e Sapienciais, que, com um forte caráter formativo, apresentam o que os hebreus cultuavam em termos de valores morais e éticos; e os dezoito Livros

\footnotetext{
${ }^{4}$ SCHMIDT, H. P. Schicksal - Gott - Fiktion. Die Bibel als literarisches Meisterwerk. Paderborn: Schöningh, 2005.
} 
Proféticos, que tratam do anúncio da palavra dos profetas, uma palavra inspirada pelo próprio Deus.

É possível notar, ao longo de livros de todos os arranjos do Antigo Testamento, o anúncio da vinda de um messias responsável pela libertação do povo hebreu de toda a dificuldade, opressão e perseguição. Muito embora os hebreus, hoje judeus, acreditem que o messias ainda esteja por vir, há vastíssima tradição em torno da crença no fato de que esse messias já tenha feito sua vinda à Terra na pessoa de Jesus de Nazaré.

A vida e os ensinamentos de Jesus de Nazaré estão registrados em narrativas nomeadas como Evangelhos que, juntamente com o livro Atos dos apóstolos, Apocalipse e uma série de compilações epistolares formam o Novo Testamento.

São quatro os evangelhos canônicos ${ }^{5}$, Mateus, Marcos, Lucas e João, cada um com uma estratégia de escrita apropriada ao interlocutor de uma época determinada.

Sob o ponto de vista narrativo, além de registrar a vida de Jesus de Nazaré, os evangelhos ainda trazem narrativas instrucionais, menores somente sob a perspectiva da extensão textual que, muito embora possam ser reconhecidas desde a literatura clássica grega de acordo com Marco Antônio Domingues Sant'Anna (2010), constituem-se como gênero literário mais definido, apenas, no Novo Testamento: as parábolas.

Sant'Anna afirma que o gênero parábola, aplicado em textos religiosos é:

[...] um símile ou uma metáfora. Em uma análise mais generalizada, pode-se dizer que em toda parábola acontece um processo de comparação. Algo que não é bem conhecido - ou ao menos prontamente reconhecido - é comparado a outra coisa que é de domínio do ouvinte/leitor. Esse processo, com ou sem a partícula comparativa, produz um insight e um entendimento que não poderiam ser reduzidos para nossa maneira convencional analítica de comunicar. Quando dois elementos diferentes são confrontados, as convenções da linguagem são temporariamente colocadas de lado a fim de acionar a imaginação em direção a uma total compreensão da realidade. Uma parábola opera em nossa imaginação por meio de um processo de símile ou metáfora. (SANT'ANNA, 2010. p. 147 -148)

Parábolas são pequenas narrativas construídas em torno de uma metáfora, cujo objetivo maior é figurar elementos abstratos de um novo conjunto de valores. São parábolas bem conhecidas a do Grão de mostarda, na qual o Reino dos Céus é equiparado à menor das sementes que, no entanto, é capaz de trazer à vida a maior das

\footnotetext{
5 Além dos quatro evangelhos canônicos, reconhecidos como livros sagrados pelas religiões bíblicas, há inúmeros outros registros que focalizam a vida de Jesus de Nazaré. Estes receberam o nome de evangelhos apócrifos e, embora não sejam reconhecidos pelas religiões bíblicas como livros sagrados, possuem inegável valor histórico e literário.
} 
árvores; e do Bom Samaritano que afirma a necessidade do exercício da compaixão sem distinção de classe, nacionalidade ou o que quer que seja.

Se na antiguidade grega, os valores disseminados eram a arete e ethos, e, no Antigo Testamento, havia um bem supremo na representação de Deus e o mal absoluto em Sua ausência, os valores bíblicos passam a afirmar um desprendimento pessoal em relação ao serviço ao outro, ao semelhante. No cristianismo, a intensidade da vida está no desapego de si e na entrega ao serviço comum, o que ficou conhecido como ágape. O maior símbolo de tal valor é a cruz, onde o próprio Jesus de Nazaré entregou sua vida por cada um dos seres humanos, sem distinção.

Após essa breve observação do desenrolar da tradição hebraica e da tradição bíbilica pela perspectiva da narrativa, foi possível refletir em torno do fato de que as narrativas fundadoras hebraicas constituíram um momento determinante para a introdução da escrita no registro das memórias de uma tradição. De maneira especular, observou-se que a representação sígnica e a representação simbólica agem sobre a temática das narrativas hebraicas, na medida em que figura, no monoteísmo, um Deus supremo que, a semelhança da representação escrita, não admite que as representações sejam entendidas como a coisa em si. Ainda por uma perspectiva temática, observou-se que à dinâmica bem x mal, estabelecida no Antigo Testamento, sucedeu-se o ágape, o desprendimento de si em favor do serviço à comunidade e ao semelhante.

\subsubsection{A Idade Média e a Narrativa Medieval Tradicional}

Tendo em vista a época medieval, quando o registro escrito ainda não atingia as camadas populares, conforme o observado no estudo das narrativas hebraicas e bíblicas, todo o intercâmbio, aprendizagem, troca de experiências e/ou relação social se dava através da fala, o aprendiz recebia os ensinamentos para desenvolver as técnicas de seu ofício através do contato com o seu mestre que, antes de se fixar em uma oficina, já havia viajado e entrado em contato com outros que realizavam o mesmo ofício. De acordo com Walter Benjamin, na obra $O$ narrador - considerações sobre a obra de Nikolay Leskov:

O sistema corporativo medieval contribuiu especialmente para essa interpenetração. O mestre sedentário e os aprendizes migrantes trabalhavam juntos na mesma oficina; cada mestre tinha sido um aprendiz ambulante antes de se fixar em sua pátria ou no estrangeiro. Se os camponeses e os marujos 
foram os primeiros mestres na arte de narrar, foram os artífices que a aperfeiçoaram. No sistema corporativo, associava-se o saber das terras distantes, trazidos para casa pelos migrantes, com o saber do passado, recolhido pelo trabalhador sedentário (BENJAMIN, 1994, p. 199).

Benjamin sinaliza a importância de dois atores sociais na disseminação dos conhecimentos através da fala: o marinheiro viajante e o camponês sedentário. "Quem viaja tem muito que contar" (BENJAMIN, 1994, p. 198), o marinheiro, aquele que empreendia viagens, ao se submeter a uma série de experiências e aventuras, acumulava vasta gama de conhecimentos e, assim, passava a ter muito a dizer, muito a compartilhar com aqueles com quem entrava em contato. Além da autoridade advinda da experiência, daquele que viveu realmente o que diz, o marinheiro também é investido da autoridade do saber que vem de longe. Tendo estado, o marinheiro, em lugares onde a maioria de seus conterrâneos nunca esteve, sua fala é investida de uma autoridade inquestionável. O camponês sedentário, "o homem que ganhou honestamente sua vida sem sair do seu país e que conhece suas histórias e tradições” (BENJAMIN, 1994, p. 198), o velho ancião, o sábio da aldeia, aquele que conserva em si o maior número de aprendizagens baseadas tanto na própria experiência como no acúmulo de experiências passadas através da fala, este também se mostra como alguém que tem muito a dizer.

Assim como a oralidade na Grécia Antiga e no contexto bíblico, a fala na idade média é uma realidade que aproxima os interlocutores, que coloca as pessoas em contato direto. A diferença reside unicamente no fato de que a fala não tem um preparo anterior, trata-se da simples repetição de uma narrativa ouvida anteriormente, através da fala de outrem, já a oralidade dos cantos gregos tem todo um preparo prévio, uma técnica própria ao aedo na qual ele entra em contato com o poema épico ou com o canto antes de sua apresentação, quando o canto não era de sua autoria, e incorpora a métrica e o ritmo. O canto era um texto de elementos estruturais e de realização bem definidos, que deveriam ser executados de acordo. $\mathrm{O}$ mesmo se dava com a oralidade em contexto hebraico, o sacerdote se preparava, entrava em contato com o texto antes de sua leitura e explanações na sinagoga.

Ainda segundo Benjamin, no momento da transferência do conhecimento através da fala, um gênero se faz essencial: novamente, a narrativa.

A narrativa tradicional medieval tinha como situação de enunciação a esfera pública, um ambiente comum no qual as pessoas se encontravam para a troca de experiências, para receber conselhos, conhecimentos fruto da tradição ou para a 
aprendizagem de determinado ofício. É interessante observar que a narrativa, na esfera pública medieval, possui um caráter utilitário incisivo. De acordo com Benjamin:

O senso prático é uma das características de muitos narradores natos. [...] Ela (a narrativa) tem sempre em si, às vezes de forma latente, uma dimensão utilitária. Essa utilidade pode consistir seja num ensinamento moral, seja numa sugestão prática, seja num provérbio ou numa norma de vida - de qualquer maneira, o narrador é um homem que sabe dar conselhos (BENJAMIN, 1994, p. 200).

De modo um pouco diverso das narrativas gregas e das narrativas bíblicas, a narrativa tradicional medieval, além de estar atrelada à instrução moral, também trazia em si um caráter prático bastante evidente, geralmente relacionado ao desenvolvimento e à aprendizagem de um ofício.

Mesmo investida de um forte caráter utilitário, a narrativa medieval não era limitada à aprendizagem e à realização de determinada função. Se, ao contrário do "ambiente público diurno", considerarmos os ambientes medievais noturnos, as tabernas e os bosques dos rituais pagãos, observa-se que outro campo bastante contemplado pelas formas narrativas eram as esferas do miraculoso e do extraordinário.

O extraordinário e o miraculoso são narrados com a maior exatidão, mas o contexto psicológico da ação não é imposto ao leitor. Ele é livre para interpretar a história como quiser, e com isso o episódio narrado atinge uma amplitude que não existe na informação (BENJAMIN, 1994, p. 2003).

Observe que, na narrativa medieval, há espaço para a reflexão e para a interpretação realizada por aquele que entra em contato com o enredo. Ao contrário das fábulas, que orientam e delimitam a interpretação com base na moral, apresentada ao final da narrativa e, ao contrário da informação, como se verá adiante, a narrativa medieval proporciona a seus receptores vasto horizonte interpretativo.

Quanto ao interlocutor submetido às possibilidades de tal discurso, Benjamin apresentou, como o já observado, o marinheiro e o camponês sedentário, no entanto, por uma perspectiva um pouco mais generalista, pode-se situar esses interactantes como elementos pertencentes à plebe, à base do sistema feudal. São trabalhadores, camponeses e artesãos, são aqueles que necessitam desenvolver um ofício, geralmente manual, para sobreviver, são os que dependem de conhecimentos da tradição para se curarem de uma doença e voltarem ao trabalho. São aqueles que recorrem à sabedoria dos anciãos para resolver suas questões existenciais, sociais, afetivas, familiares etc. $\mathrm{O}$ 
reconhecimento dos interlocutores do gênero narrativo como trabalhadores manuais é importante para compreender mais um elemento pertencente ao gênero narrativo: o ritmo do andamento.

\footnotetext{
Contar história sempre foi a arte de contá-las de novo, e ela se perde quando as histórias não são mais conservadas. Ela se perde porque ninguém mais fia ou tece enquanto ouve a história. Quanto mais o ouvinte se esquece de si mesmo, mais profundamente se grava nele o que é ouvido. Quando o ritmo do trabalho se apodera dele, ele escuta as histórias de tal maneira que adquire espontaneamente o dom de narrá-las. Assim se teceu a rede em que está guardado o dom narrativo (BENJAMIN, 1994, p. 205).
}

Observe a profunda relação entre a narrativa e o trabalho manual. A situação de trabalho manual proporciona o ambiente de realização propício ao uso, ao exercício do gênero narrativo. Não é nenhum exagero inferir que, o desaparecimento da relação de trabalho medieval implicaria certa asfixia da narrativa. Mais uma vez, observa-se como é forte a identidade de um tempo, de uma época e a utilização mais frequente de determinado gênero.

Paralelamente a essa progressão empreendida pela narrativa tradicional medieval, havia também todo um desenvolvimento filosófico com origem nos valores bíblicos. Com seus maiores expoentes nas obras escritas de Tomás de Aquino e Agostinho de Hipona, a filosofia medieval ficava encerrada nos mosteiros católicos e estava mais voltada a um prosseguimento temático, abstrato, próprio das reflexões argumentativas teóricas.

Com base na observação do uso da narrativa durante a idade média, é importante destacar que esta circulava através da fala, em ambientes públicos, entre os trabalhadores camponeses. Ela exercia, além de um caráter formador moral e ético, um forte veio instrutivo prático atrelado a exposição de sugestões, provérbios e conselhos. A narrativa contava ainda com o ritmo do trabalho manual camponês, proporcionando identidade e aproximação entre os camponeses em seu ofício diário. Além disso, o gênero narrativo oferece o molde e o ritmo perfeitos para o trato dos temas da realidade campesina. Mais do que isto, a narrativa é a forma através da qual o trabalhador medieval adquire voz diante do ambiente público, é a forma através da qual ele se pronuncia, toma parte na cadeia de enunciados de seu tempo, na qual ele constrói sua identidade e exerce sua postura diante de sua realidade. 


\subsubsection{A Pos-Medievalidade e o Romance}

Com a ascensão da burguesia como detentora dos meios de produção industriais a partir do século XV, a estrutura social medieval e suas formas de produção e organização do trabalho começam a desaparecer.

A velocidade de produção de bens se intensifica, assim como a necessidade de se instalar uma dinâmica de consumo que circule os bens produzidos, gerando acúmulo de divisas para a burguesia. A carga valorativa depositada, até a medievalidade, na experiência de vida acumulada pelo viajante ou pelo ancião, migra para aquele que acumula o maior número de bens e/ou de capital, para aquele mais intensamente inserido na dinâmica do acúmulo. Surge, assim, a supremacia do "ter" sobre o "ser".

Como o objetivo passa a ser o acúmulo, é necessário que se reserve espaço e tempo para a interação do consumidor com seus objetos de consumo. Aquilo que antes era tempo dispendido com o outro, em presença, no ambiente público, na apreciação de narrativas, começa, paulatinamente, a ser investido em uma realidade mais reservada. Inicia-se a organização um pouco mais significativa da vida privada, na qual o sujeito se retira do ambiente público, distanciando-se do outro, estabelecendo novos eixos de reflexão, novas questões e experimentando novos sentimentos. Sobre essa migração do foco de atenção da esfera pública para a realidade privada e suas consequências, Michel Maffesoli, na esteira de Norbert Elias, Michel Foucault, Max Weber e Émile Durkheim, sintetiza o seguinte:

Os trabalhos de Norbert Elias, do próprio Michel Foucault, ou os de inspiração foucaultiana esclarecem bem o lento processo de "curialização" ou de domesticação dos costumes que levou à constituição "do" social, isto é, de um estar-juntos singularmente mecanizado, perfeitamente previsível e essencialmente racionalizado. "Racionalização generalizada da vida", disse Max Weber. Tendenciosa com certeza. De qualquer modo, foi justamente esse processo que regeu o nascimento de uma família cristalizada em sua estrutura nuclear, que favoreceu a "implementação do trabalho" e gerou as grandes instituições de ensino e do trabalho social, sem esquecer as de saúde e os diversos tipos de "confinamento" em que os séculos XIX e XX não foram nada avaros. Corrigindo, na medida em que isso era possível, os malefícios do devir econômico do mundo e do produtivismo que lhe era inerente, esse "social" trouxe uma segurança inegável para a grande maioria. Mas, ao mesmo tempo, e no sentido estrito do termo, "enervou" o corpo comunitário, transferindo para instâncias longínquas e abstratas a tarefa de gerir o bem comum e os liames coletivos. Tudo isso me levou a dizer que, em muitos aspectos, assistimos à instauração de uma "violência totalitária" que, invertendo a terminologia durkheimiana, permitiu o deslizamento de uma "sociedade orgânica", mais próxima do cotidiano, para uma "solidariedade mecânica" promovida por uma estrutura técnica 
que se autoproclamava avalista do bom funcionamento da vida social. (MAFFESOLI, 2004. p. 14 - 15. Grifo nosso.)

O confinamento privado lançou bases para o início de uma redução da esfera de presença e de atuação do ser humano. O abandono da atuação do homem moderno sobre a esfera pública, sobretudo, em relação ao bem comum, acabou relegado este a uma instância demasiada abstrata, cuja definição e normas de atuação eram desconhecidas. O que antes era de todos passou a ser de ninguém. Consequentemente, alterou-se a estrutura das instituições sociais de ensino, saúde e trabalho.

Retomando a íntima relação, existente na medievalidade, entre o trabalho manual e a narrativa e observando a alteração da estrutura de trabalho de uma realidade manual para o ritmo industrial, constata-se que a ocasião de encontro entre dois seres humanos em torno da narrativa foi substituída por um objeto de consumo: o romance no formato de livro impresso. De acordo com Walter Benjamin:

\begin{abstract}
O romance, cujos primórdios remontam à Antiguidade, precisou de centenas de anos para encontrar na burguesia ascendente, os elementos favoráveis a seu florescimento. Quando esses elementos surgiram, a narrativa começou pouco a pouco a tornar-se arcaica; sem dúvida, ela se apropriou de múltiplas formas, do novo conteúdo, mas não foi determinada verdadeiramente por ele. (BENJAMIN, 1994, p. 202).
\end{abstract}

Por mais que se tentasse abarcar a nova temática e a nova forma, a narrativa medieval tradicional não comportou mais as necessidades do homem moderno, cujo recolhimento na realidade privada fez curvar o olhar sobre si mesmo, tornando suas considerações e reflexões mais subjetivas e introspectivas, descobrindo o universo de símbolos e representações que há em cada um. A substituição do encontro com o outro, na narrativa falada, por um objeto capaz de ser possuído e desfrutado no refúgio da realidade privada fez com que o valor da contribuição do outro, da tradição, da experiência que constitui autoridade, do conselho advindo da vivência do outro evanescesse diante da autonomia, da possibilidade de construção de sentido independente. Ainda, de acordo com Benjamin:

O que separa o romance da narrativa (e da epopeia no sentido estrito) é que ele está essencialmente vinculado ao livro. A difusão do romance só se torna possível com a invenção da imprensa. A tradição oral, patrimônio da poesia épica, tem uma natureza fundamentalmente distinta da que caracteriza o romance. O que distingue o romance de todas as outras formas de prosa contos de fada, lendas e mesmo novelas - é que ele nem procede da tradição oral nem a alimenta. Ele se distingue, especialmente, da narrativa. 
O narrador retira da experiência o que ele conta: sua própria experiência ou a relatada pelos outros. E incorpora as coisas narradas à experiência de seus ouvintes. O romancista segrega-se. A origem do romance é o indivíduo isolado, que não pode mais falar exemplarmente de suas preocupações mais importantes e que não recebe conselhos e não sabe dá-los. (BENJAMIN, 1994, p. 201. Grifo nosso.)

Embora a emancipação do leitor em relação ao autor do romance represente um movimento libertário interessante na possibilidade de edificação de novas leituras e novos sentidos, concretizando a polifonia da leitura, há, nessa transição, uma migração irreversível de um momento de encontro entre narrador e ouvinte para uma segregação entre autor e leitor, a importância não recai na realização da narrativa pelo narrador e na condução deste acerca do fato narrado, mas na experiência reclusa da leitura sozinho, no ambiente privado, no manejo significativo de simbologias pessoais e de experiências em caráter íntimo. Por uma perspectiva um pouco mais generalista, é possível observar o leitor do romance em uma situação de cisão entre duas realidades: o mundo real e o seu universo introspectivo-reflexivo, que mais se aproxima da atitude filosófica do que da força anímica presente na narrativa. Georg Lukács, em A teoria do romance, expressa a aproximação entre romance e pensamento filosófico com maior propriedade:

[...] a filosofia, tanto como forma de vida como quanto a determinante da forma e a doadora de conteúdo da criação literária (no caso do romance), é sempre um sintoma da cisão entre interior e exterior, um índice da diferença essencial entre eu e mundo, da incongruência entre alma e ação. (LUKÁCS, 2000. p. 25)

Por essa perspectiva mais filosófica, o que resulta da experiência do outro, o conselho e a tradição perdem a importância. O que aparece com maior relevância é a construção subjetiva de sentidos, a perplexidade da dimensão introspectiva, na qual a companhia se dá exclusivamente no contato entre o leitor e a obra lida. Até mesmo a intensão do autor na escrita do romance é colocada em um patamar menor diante da experimentação reclusa que se dá entre leitor moderno e a obra lida. A possessão entre leitor e livro é singular.

$\mathrm{Na}$ tentativa de dar corpo discursivo a essa passagem experimentada pelo homem moderno da concretude da narrativa tradicional para a abstração reflexiva do romance, a transição da escrita em verso para a prosa é fatal. Para Lukács "o verso" no caso da poesia épica "não é um constituinte último, mas antes um sintoma profundo, um divisor de águas que lhes traz à luz a verdadeira essência da maneira mais autêntica e 
apropriada” (LUKÁCS, 2000. p. 55). Ainda acerca do verso épico, o filósofo húngaro afirma:

\begin{abstract}
A feliz totalidade existente da vida está subordinada ao verso épico segundo uma harmonia preestabelecida: o próprio processo pré-literário de uma abrangência mitológica de toda a vida purificou a existência de qualquer fardo trivial, e nos versos de Homero, os botões dessa primavera já prestes a florescer não fazem mais que desabrochar. O verso, porém, só pode dar um ligeiro impulso a essa floração e cingir com a guirlanda da liberdade somente o que se desprendeu de todas as peias. (LUKÁCS, 2000. p. 57)
\end{abstract}

Diferentemente, em relação à prosa, Lukács irá ponderar:

\begin{abstract}
Nos tempos em que essa leveza não é mais dada, o verso é banido da grande épica [...]. Somente a prosa pode então abraçar com igual vigor as lamúria e os lauréis, o combate e a coroação, o caminho e a consagração; somente sua desenvolta ductibilidade e sua coesão livre de ritmo captam com igual força os liames e a liberdade, o peso dado e a leveza conquistada ao mundo, que passa então a irradiar com imanência o sentido descoberto [...] no verso tudo o que está oculto torna-se manifesto, e a distância, que o passo cauteloso da prosa transpõe com arte por meio do sentido que se insinua pouco a pouco, vem a lume em toda a sua nudez, escarnecida, espezinhada ou como sonho esquecido na rápida carreira dos versos. (LUKÁCS, 2000. p. 58.)
\end{abstract}

O marco instituído pela alteração de concepções é tamanho que exigiu uma nova forma, uma nova maneira discursiva que abarque as novas orientações reflexivas. $\mathrm{O}$ verso épico, mais harmônico e relativo à totalidade experimentada pelo homem antigo, que se percebe na intensidade de suas ações sobre um mundo concreto, cede espaço à escrita em prosa, livre da geometria sonora, extremamente amorfa, volátil e, portanto, hábil na maleabilidade de penetrar às profundezas dos abismos reflexivos-especulativos, nos quais o ser humano se converteu com o advento da modernidade.

Muito embora possuidor de uma realidade própria, de um universo de simbologias e representações, o homem moderno observa a impossibilidade de se viver sob a égide de tal realidade. A redução da vida moderna ao ciclo de produção e consumo, a busca por possuir bens e capital, além da relação de si consigo mesmo na esfera privada acabaram por determinar uma realidade fria, vazia de maiores realizações. Surge uma tristeza reflexiva profunda, uma melancolia pensativa diante da qual o romance aparece como um apaziguador, um consolo, um suspiro de magia ante uma realidade insípida.

O romance não é significativo por descrever pedagogicamente um destino alheio, mas porque esse destino alheio, graças à chama que o consome, pode dar-nos o calor que não podemos encontrar em nosso próprio destino. O que 
seduz o leitor no romance é a esperança de aquecer sua vida gelada com a morte descrita no livro. (BENJAMIN, 1994. p. 214)

Muito além de forma maior da expressão de uma realidade determinada, o romance é, fundamentalmente, sobretudo por uma perspectiva temática, a tábua de salvação para o vazio da vida burguesa que busca, nas reflexões filosóficas em relação ao destino alheio, um resquício de esperança para a própria vida. Daí a frequente utilização dos temas da vida privada: o amor conjugal, a traição, os vícios, a solidão, a efemeridade, o acúmulo, a inveja, a vingança, entre muitos outros, porém, sempre temperados com uma observação ou uma reflexão mais aprofundada diante da qual a pequenez se converte em algo mais substancial, capaz de tornar a existência um pouco mais significativa e, portanto, tolerável. O caráter exemplar, observado desde a antiguidade, aparece no romance, mas com contornos bem mais dramáticos: o que, na Grécia Antiga, tendia a reservar e perpetuar valores tais como arete e ethos, na modernidade, passa a inebriar, a realizar um distanciamento do leitor em relação à sua realidade vazia, garantindo, na identificação entre leitor e herói, um espaço de satisfação, um momento de calor ante à realidade gelada do refúgio privado.

Em termos gerais, foi possível observar que a modernidade efetivou vasta gama de alterações na forma como o homem compreendia a sua realidade. Inicialmente, a alteração das formas de produção trouxe um ritmo mais acelerado além de uma valoração muito mais pautada sobre o acúmulo de bens e de divisas. Essa alteração valorativa terminou por relegar a esfera pública aos domínios de uma imprecisa instância abstrata, e por refugiar o homem moderno nos domínios da esfera privada, onde este curvou o olhar sobre si mesmo, descobrindo-se como o detentor de um universo de relações simbólicas reflexivas próprias. Tal descoberta aproximou o homem moderno da atitude filosófica, iniciando por relegar o caráter anímico, presente nas narrativas épicas e medievais, à obsolescência. Para dar conta da passagem de uma concepção mais figurativa para algo mais reflexivo-subjetivo, a forma mais determinada das narrativas, concebidas através do verso metrificado e com rimas, cedeu espaço à prosa, em sua concepção bem mais volátil, capaz de capturar e compreender em palavras a elaboração abstrata perseguida no romance. Finalmente, observou-se que a convergência de fatores tais como $\mathrm{o}$ isolamento na realidade privada e o aprofundamento de um pensamento abstrato-reflexivo resultaram em uma realidade fria, diante da qual o romance aparece não apenas como tradução de uma época, mas, 
sobretudo, como fonte de calor, mantendo a pulsão de vida em um cenário frio e melancólico.

\subsubsection{A Narrativa na Contemporaneidade}

Tratar da narrativa na contemporaneidade é, antes de tudo, um grande desafio. $\mathrm{Na}$ realidade, tratar de qualquer que seja a instância em termos de contemporaneidade é consideravelmente dificultoso, pois falta a distância histórica capaz de proporcionar foco à vista, de realçar aos olhos aquilo que realmente é característico de uma época. Tudo é tão intensamente próximo e intimamente constitutivo que produz uma série de pontos cegos. As questões nos são fundadoras e, portanto, não resolvidas, talvez, até mesmo, ainda não nomeadas. Há um não saber definir, um obscurantismo. Agamben irá defender que "[...] contemporâneo é aquele que mantém fixo o olhar no seu tempo, para nele perceber não as luzes, mas o escuro.” (AGAMBEN, 2009. p. 62). Mais adiante, o filósofo italiano irá concluir:

[...] o contemporâneo não é apenas aquele que, percebendo o escuro do presente, nele apreende a resoluta luz; é também aquele que, dividindo e interpolando o tempo, está à altura de transformá-lo e de colocá-lo em relação com os outros tempos, de nele ler de modo inédito a história, de "citála" segundo uma necessidade que não provém de maneira nenhuma do seu arbítrio, mas de uma exigência a qual ele não pode responder. (AGAMBEN, 2009. p. 72)

Mais do que uma alteração entre luz e escuro, Agamben trata da oscilação de um presente em si e um presente resultante de um passado, que retoma suas origens. Mesmo observando a dificuldade de se tratar da contemporaneidade, a reflexão de Agamben ajuda a delinear uma dinâmica oscilante, espiralada, não apenas considerando o movimento entre a luz e as trevas, mas também no sentido de quem retoma o passado para elaborar um movimento no presente, como alguém que olha para trás antes de dar um passo à diante. A constatação dessa dinâmica espiralada é confirmada por Maffesoli:

Para sermos mais exatos, não se trata de um "eterno retorno" do mesmo, e sim, como indicou em sua época o filósofo Nicolau de Cusa, de um crescimento que assume a forma de espiral. Para dizê-lo com clareza ainda maior, se fosse preciso dar uma definição, ela poderia ser: "A sinergia de fenômenos arcaicos com o desenvolvimento tecnológico”. [...] é bom que, por humildade, saibamos voltar ao "húmus" a partir do qual se moldou o que é "humano". (MAFFESOLI, 2004. p. 21. Itálicos do autor.) 
É possível que essa sinergia entre o arcaico e o tecnológico, mencionada por Maffesoli, seja o que há de mais preciso, até o momento, no sentido de produzir uma síntese da era contemporânea. Muito embora o advento da tecnologia proporcione vastíssima gama de possibilidades de acesso ao conhecimento, variadíssimas linguagens através das quais se pode elaborar, expressar e comunicar novas ideias, o pensamento humano parece trazer à tona o que há de mais "arcaico"'. A supervalorização da informação evidencia bem esse amalgama entre o tecnológico e o arcaico. De acordo com Benjamin:

[...] com a consolidação da burguesia - da qual a imprensa, no alto capitalismo, é um dos instrumentos mais importantes - destacou-se uma forma de comunicação que, por mais antiga que fossem suas origens, nunca havia influenciado decisivamente a forma épica. Agora ela exerce essa influência. Ela é tão estranha à narrativa como o romance, mas é mais ameaçadora e, de resto, provoca uma crise no próprio romance. Essa nova forma de comunicação é a informação. (BENJAMIN, 1994. p. 202. Grifo nosso.)

Por mais que Benjamin esteja se referindo ao início da expansão da informação na modernidade, pode-se afirmar que a informação perpetuou o seu império ao longo da contemporaneidade, evidenciando a sinergia entre o arcaico e o tecnológico não apenas por ser uma forma, cujas origens remetem a um tempo antigo, exaltada pela tecnologia da informação em rede, mas por sua condição de imediatismo, desrazão e narcisismo que apontam para uma condição anterior ao amadurecimento da razão, não apenas em sua dimensão lógico-objetiva, mas também, e sobretudo, em relação à inteligência afetiva, no sentido humano. Benjamin continua:

\footnotetext{
Villemessant, o fundador do Figaro, caracterizou a essência da informação com uma fórmula famosa. "Para meus leitores", costumava dizer, "o incêndio num sótão do Quartier Latin é mais importante que uma revolução em Madrid." Essa fórmula lapidar mostra claramente que o saber que vem de longe encontra hoje menos ouvintes que a informação sobre acontecimentos próximos. (BENJAMIN, 1994. p. 202)
}

Além da ressalva de Benjamin acerca da valorização narcísica, pela informação, do que é próximo em relação ao que vem de longe, o contrário, portanto, da dinâmica de valorização da narrativa medieval tradicional, baseada sobre o conhecimento que vem

\footnotetext{
${ }^{6}$ A palavra "arcaico" utilizada aqui, embora expresse um significado pejorativo, não tenciona estabelecer nenhum tipo de reflexão valorativa, ela é usada, apenas, para retomar o termo utilizado por Maffesoli.
} 
de longe, a informação também conta com um caráter imediato e uma necessidade de plausibilidade que vão contra o exercício reflexivo ou mesmo racional.

Em relação à sua imediatez, é importante observar que a própria necessidade de velocidade na divulgação da informação faz dela um elemento avesso à reflexão na medida em que reflexão, ponderação, pensamento demandam tempo, um tempo destinado à elaboração de lembranças, associações, aproximações, estabelecimentos de paralelos, de uma ordem cronológica, entre muitos outros processos. Em suma, pensar demanda tempo, um tempo do qual a informação não dispõe. Quando se elabora um desenvolvimento acerca de uma determinada informação, esta já se dissipou, já foi substituída por inúmeras outras, com implicações diversas sobre o pensamento estabelecido. O ritmo imposto pela informação aliena, a velocidade implica obsolescência do pensamento.

Além da imediatez, outro traço forte da informação que vai contra a dinâmica reflexiva é a plausibilidade. Enquanto a narrativa propõe uma ocasião de pensamento, um mistério que se evanesce diante da explicação, a informação, ao contrário, necessita de um percurso dado, diante do qual o interlocutor, apenas, efetiva um acompanhamento e, ao final, aceita. Não há necessidade de uma elaboração paralela ou da consideração por uma perspectiva variada, apenas a compreensão e a tácita aceitação da elaboração exposta como verdadeira. Para Benjamin:

\footnotetext{
A informação só tem valor no momento em que é nova. Ela só vive nesse momento, precisa entregar-se inteiramente a ele e sem perda de tempo tem que se explicar nele. Muito diferente é a narrativa. Ela não se entrega. Ela conserva suas forças e depois de muito tempo ainda é capaz de se desenvolver. (BENJAMIN, 1994. p. 204)
}

Obviamente que o caráter imediato e a plausibilidade exigidos pela informação são importantes em determinados meios, não se pode tomar uma série de decisões sem levar em conta certo número de informações, no entanto, o presente estudo trata dos gêneros em relação à humanização, sobretudo, em relação à aproximação e ao isolamento entre pessoas, ao estímulo reflexivo-fruitivo diante da leitura de textos literários entendidos como obras de arte e, sob essa perspectiva, a informação, em sua plausibilidade e imediatez, acaba indo contra traços fundamentais da condição humana tais como a reflexão e a degustação artística-simbólica. Tal esvaziamento, em níveis mais elevados, acaba por retirar do ser humano a capacidade de atribuir significância, de 
traduzir em palavras a própria experiência, abandonando-o no vazio da não percepção da própria vida. De acordo com Agamben:

É essa incapacidade de traduzir-se em experiência que torna hoje insuportável - como em momento algum do passado - a existência cotidiana, e não uma pretensa má qualidade ou insignificância da vida contemporânea confrontada com a dor do passado (aliás, talvez jamais como hoje a existência cotidiana tenha sido tão rica de eventos significativos). (AGAMBEN, 2005. p. 22)

Há, conforme Agamben, uma atrofia da capacidade de se narrar, da capacidade de significar a própria experiência, o que resulta de um processo de alienação da narratividade como forma de pensamento ${ }^{7}$. Não se trata da afirmação de um saudosismo ingênuo, muito pelo contrário, Agamben defende que nunca, como hoje, as experiências foram tão significativas, o problema reside no fato de que o ser humano está perdendo a capacidade de perceber tais vivências de forma efetiva.

Retomando a dinâmica sinérgica entre o "arcaico" e o tecnológico, por uma perspectiva social, observa-se que a contemporaneidade apresenta uma movimentação neotribalista cuja função é a mesma da época dos grupos humanos nômades entre as mais variadas paisagens terrestres:

De fato, as instituições sociais, havendo-se tornado cada vez mais abstratas e
desencarnadas, já não parecem estar em contato com a exigência reafirmada
de proximidade. Daí a emergência de um neotribalismo pós-moderno que se
assenta na necessidade - sempre e mais uma vez - de solidariedade e
proteção que caracteriza todos os grupos sociais. Nas selvas de pedra que são
as megalópoles contemporâneas a tribo desempenha o papel que lhe competia
na selva stricto sensu. (MAFFESOLI, 2004. p. 23)

A desmoralização da esfera pública e a entrega do bem comum a instituições cada vez mais abstratas, de orientação extremamente duvidosa, conforme o observado na modernidade, terminou por justificar a união de seres humanos em grupos cuja função maior é proporcionar proteção em meio à selva de pedra. A tribo, o pequeno grupo organizado em torno de semelhanças étnicas, sociais, culturais e/ou de cunho ético valorativo, promoveu um forte movimento de fragmentação e heterogeneização dado que, diante das tribos “A verdade absoluta, que é preciso esperar, fragmenta-se em verdades parciais que convém viver [...]. Daí a babelização potencial que, comumente,

\footnotetext{
${ }^{7}$ Haverá maior cuidado com a descrição da narratividade como forma de pensamento a seguir, no subtítulo A narratividade como forma de pensamento.
} 
as pessoas se empenham em negar, invocando o espectro da globalização" (MAFFESOLI, 2004. p. 25).

Há, na descrição de Mafesoli acerca da ação humana através da tribo, um movimento de retomada do ambiente público, porém, não por uma perspectiva espontânea, mas por uma perspectiva fundamentada na "verdade absoluta" cultuada por cada tribo. Não é o ser humano em si que encontra outro ser humano, é o ser humano, frequentemente, sob a proteção de uma máscara social, de uma identidade forjada no sentido de sustentar a tribo. Nesse sentido, a "[...] identidade se fragiliza. As identificações múltiplas, ao contrário, multiplicam-se. As grandes aglomerações musicais, esportivas, ou de consumo são um testemunho disso. Em cada um desses casos, trata-se de um perder-se no outro." (MAFFESOLI, 2004. p. 26).

Esse "outro", diante do qual há a dissolução de si, é definido por Maffesoli como sendo:

[...] busca da fusão. Cada um só existe no e pelo olhar do outro. E isso, quer o outro seja o da tribo afim, quer seja a alteridade da natureza ou o grande Outro que é a divindade [...]. Em suma, já não há mais autonomia - sou a minha própria lei que prevalece - mas heteronomia: minha lei é o outro. (MAFFESOLI, 2004. p. 27).

No desejo de atender ao outro como lei, de se identificar como pertencente à tribo e gozar de sua solidariedade e proteção, a imagem aparece valorizada a níveis histriônicos. De modo muito frequente, todo esse simulacro de si mesmo é falso e conduz o ser humano à fragmentação profunda na medida em que ele se constata distante da imagem criada, sem conseguir perceber e/ou nomear a intensidade contida em suas experiências autênticas. Retomando a questão da perda da capacidade de traduzir-se em experiência, conforme a citação de Agamben (2005), tudo se converte em vazio. A partir daí, a concepção da depressão como o mal do século XXI e o aumento das taxas de suicídio é mera consequência. No império da vastidão das linguagens, o ser humano adoece por não saber nomear, não atribuir a significação e/ou a significância devidas à realidade experimentada. Negando, assim, o que há de fundamental e definitivo na condição humana, o ser despenca nas profundezas abissais de um vazio aterrador: o vazio da não significação.

Mesmo a tribo representando essa união de seres humanos em torno de interesses ou identidades aproximadas, sejam elas reais ou não, o elo que justifica tal união é convertido em consumo, seja ele físico ou virtual. Aumentam as vendas e as buscas por atender esses consumidores. O que, na modernidade, estava mais restrito ao romance no 
formato de livro impresso, físico, agora, recebe uma explosão de gêneros constituídos sobre as mais variadas linguagens, nas mais variadas modalidades e mídias. Os serviços de streaming se multiplicam e possibilitam o acesso e a divulgação de material de um vastíssimo número de autores.

Especificamente em relação à narrativa, observa-se, entre os anos 1970 e 1980, uma verdadeira virada, baseada na valorização dos gêneros narrativos em suas mais variadas esferas: o narrative turnning. Trata-se de uma verdadeira explosão do uso da narrativa descaracterizando-a como um objeto estético artístico, capaz de prover uma experiência fruitiva, e transformando-a em um instrumento para este ou aquele fim. $\mathrm{O}$ storytelling é um exemplo cabal no qual o desenvolvimento narrativo é utilizado com o objetivo de conquistar consumidores, efetivar um maior número de vendas etc. De acordo com Michèle Petit, na obra $A$ arte de ler ou como resistir à adversidade:

\footnotetext{
Hoje nós estaríamos em uma "nova ordem narrativa", na era do storytelling. No começo dos anos 1990, nos Estados Unidos, em resposta à crise do modelo empresarial, os dirigentes econômicos teriam redescoberto a importância das narrativas para atrair seus trabalhadores nas redes de uma ficção comum. Os políticos teriam igualmente apostado nas narrações para mobilizar e instrumentalizar as emoções, para ganhar o poder e mantê-lo. Da mesma forma, eles mudaram a maneira de se expressar e passaram a contar histórias. "Os novos relatos" que nos propõe Christian Salmon, "evidentemente não exploram as condições de uma experiência possível, mas as modalidades de submissão". É por isso que, segundo ele, "a luta dos homens por sua emancipação não poderia ser satisfeita por esses novos poderes; ela passa pela reconquista de seus meios de expressão e de narração". (PETIT, 2009. p. 137 - 138. Grifo nosso.)
}

Com a perda da concepção da narrativa como um objeto artístico e a sua utilização como meio de manipulação e submissão, surge uma primeira necessidade em relação à narrativa: a retomada de seu caráter artístico na elaboração linguística formal de uma experiência em termos significativos.

Trabalhando no sentido de retomar a narrativa como forma artística significativa e buscando sistematizar, por um viés pedagógico, os setores de produção de linguagem contemporâneos, Maria Zilda da Cunha, incorporando as teorias de Pierce e Santaella, elaborou três paradigmas: “[...] teríamos as narrativas primordiais derivadas das manifestações orais, no primeiro paradigma; as formas híbridas de literatura [...], no segundo; e as recentes produções infográficas, no terceiro" (CUNHA, 2009. p. 22). 
Tanto as narrativas primordiais retomadas nas modalidades das mídias da tecnologia em rede como as formas híbridas e as produções infográficas trazem em si uma nova linguagem revolucionária: a hipermídia. De acordo com Cunha:

\begin{abstract}
Trata-se, de fato, de uma linguagem inaugural em um novo ambiente de informação no qual ler, perceber, escrever, pensar e sentir passam a adquirir características inéditas. $\mathrm{O}$ grande poder definidor da hipermídia está no confluir das matrizes de linguagem e pensamento, na hibridização de mídias que ela aciona, e, consequentemente, na mistura de sentidos receptores e na sinestesia reverberante conforme o receptor interage, co-operando na sua realização. Sendo assim, é uma nova linguagem que necessita de sintaxes, ou melhor, de hiper-sintaxes que sejam capazes de refuncionalizar linguagens, retecendo-as e recombinando-as em uma mesma malha multidirecional. (CUNHA, 2009. p. 181).
\end{abstract}

Em meio a toda essa explosão de objetos narrativos e retomando a dinâmica sinérgica característica da contemporaneidade, garantem o seu espaço entre as produções atuais e hipermidiáticas o teor épico das narrativas gregas antigas e as narrativas tradicionais medievais tanto em termos de produções contemporâneas que recuperam essas configurações, as Metal Operas por exemplo, como a retomada das obras antigas e medievais, haja vista as inúmeras reedições e adaptações de Ilíada e Odisséia nas mais variadas mídias. Considerando a forma dos gêneros, a hipermídia, em seu caráter confluente das matrizes de linguagem e pensamento, acaba trazendo à tona uma série de elementos relativos às formas narrativas "arcaicas", revisitando, na medida do possível, a ocasião de interação face a face, através das lives, e possibilitando espaço de preservação da narrativa oral, fundadas sobre a experiência, em uma vasta gama de canais, sobretudo da plataforma YouTube, especializados na disseminação de narrativas sobre os mais diversos eixos temáticos.

Espaço para a realização e circulação dos mais variados objetos narrativos, certamente, não é mais o maior dos problemas. O desafio maior reside sobre a busca e o desenvolvimento de novas sintaxes, novas perspectivas de leitura e compreensão desses novos objetos tão sinestésicos, simultâneos e sinérgicos, na tentativa de retomar e/ou refinar a apreciação simbólica fruitiva. Nas palavras de Maria Zilda da Cunha: "Em um ambiente como a hipermídia, não apenas técnico, mas vital, os artistas desbravam territórios tendo em vista a interação e trânsito de nossos sentidos, da nossa inteligência e a regeneração da sensibilidade humana" (CUNHA, 2009. p. 182).

Compreendendo a dificuldade de se tratar de qualquer que seja a instância na contemporaneidade, observou-se que é próprio desta a imersão em uma oscilação entre 
pontos claros e pontos mais obscuros. A própria dinâmica entre a luminosidade e o obscurantismo revelou algo que pode ser característico e definidor de nossa contemporaneidade: a sinergia entre o tecnológico e o "arcaico". Essa sinergia foi observada na valorização da informação, em seu caráter imediato e em sua plausibilidade, assim como na retomada do neotribalismo. $\mathrm{O}$ elo que justifica a união dos seres viventes em torno de uma tribo orientada por interesses ou identidades aproximadas, sejam elas reais ou não, é convertido em consumo, seja ele físico ou virtual. A partir daí, explodem as mais variadas produções, nos mais variados formatos. A hipermídia passa a orientar uma verdadeira revolução não apenas retomando o "arcaico", mas devorando-o, no sentido antropofágico, para trazer à luz o novo. O desafio atual não reside mais no acesso ou na circulação dos objetos narrativos, mas no desenvolvimento de novas sintaxes, novas formas de leitura capazes de proporcionar um refino da capacidade simbólica humana.

\subsection{A Narrativa, Seus Elementos Constitutivos e Suas Relações}

Partindo desse breve panorama histórico, passemos à consideração de alguns elementos característicos da narrativa. Iniciaremos sob a perspectiva de sua estrutura, passaremos à consideração da narratividade enquanto forma cognoscente e observaremos as relações da narrativa com os processos de humanização e desumanização na medida em se constata a capacidade de narrar como algo em vias de asfixia.

\subsubsection{Aspectos Estruturais Iniciais}

O texto narrativo possui algumas características basilares. De acordo com José Luis Fiorin (1994), tais características são: a) focalizar transformações que se pressupõem umas às outras; b) possuir um discurso figurativo; c) utilizar tempos verbais perfectivos; d) manter uma relação de anterioridade e posterioridade que não pode ser alterada sem afetar a compreensão do texto.

De acordo com Fiorin (1994), os gêneros narrativos, invariavelmente, versarão acerca de uma transformação. Haverá um estado inicial de equilíbrio que passará por 
alguma instabilidade e voltará ao estado de equilíbrio através de alguma mudança. O fluxo da dinâmica equilíbrio-instabilidade-(r)equilíbrio ao longo do tempo do enredo é o que se entende por narratividade, que pode ser empregada uma única vez ou diversas vezes dentro do enredo, de forma que quanto mais ela se repete, mais complexa tende a ser a narrativa.

O discurso figurativo é uma propriedade narrativa que tende a tratar de elementos abstratos através do acontecimento de um ato concreto. Nas palavras de Fiorin, “[...] o discurso figurativo tem a finalidade de criar um simulacro do mundo, representando-o no interior da linguagem [...]" (FIORIN, 1994. p. 63). Daí a excelência da narrativa no desenvolvimento formativo e o seu forte caráter exemplar, pois nada poderia ser melhor para materializar valores e condutas do que a narração de um ato concreto sobre o mundo, um feito verossímil que retrate tais elementos.

Os tempos verbais perfectivos não apenas corroboram o caráter figurativo da narrativa, afirmando certa conclusibilidade e concretude à ação narrada, como também preservam o texto de alterações no desenvolvimento das ações ao longo do tempo determinado pelo enredo. "Essas ações que se pressupõem são apresentadas como uma sucessão no tempo. Por isso, ganha relevo na narração a relação de anterioridade e posterioridade. Por essa razão, os tempos centrais da narração são os perfectivos" (FIORIN, 1994. p. 68). Os tempos verbais perfectivos, por seu caráter fluídico, operam de maneira fundamental na efetivação da já mencionada narratividade.

Embora haja inúmeras formas de se organizar os fatos em uma narrativa alterando a sua apresentação através do emprego de mecanismos como a medias res ou o flashback, os acontecimentos devem obedecer a uma lógica cronológica determinada, elementos posteriores não podem ter sua realização antes de elementos anteriores, e vice-versa, sem alterar a compreensão do recorte narrado.

Além do que é específico e definidor em relação à narrativa, é importante reservar a ela certa flexibilidade e espaço. Régine Delamotte-Legrand, partindo do estipulado por Frédéric François, afirma que:

Frédéric François pensa que propor um modo de falar da narrativa com o qual todo o mundo concordaria leva a formular generalidades muito vagas (ou evidências) e impede de formular questionamentos necessários ao debate. Aqueles que lhe são próprios dizem respeito à tensão entre a permanênciaestabilidade do gênero narrativo e a diversidade de suas realizações, assim como a amplitude da variação interindividual [...] Trata-se do risco de estabelecer regras e normas linguageiras a partir do momento em que se trata das realidades mais vastas do que a frase e, portanto, da dificuldade 
transmitida pelos modelos que deixam possíveis aberturas para o inédito, a criatividade. Daí a necessidade, portanto, se quisermos nos proteger de uma reprodução estereotipada, de relativizar os modelos estruturais dos gêneros de discurso, da narrativa, em particular (DELAMOTTE-LEGRAND, 2009 p. 17).

Diante do vastíssimo horizonte de representação narrativo é importante conceder às formas narrativas certa flexibilidade, pois é aí que agirá a criatividade, inovando a maneira de se transmitir fatos ocorridos ou imaginados. É essa flexibilidade, tanto em termos temáticos como composicionais, que estabelece a narrativa como antípoda da informação dado que esta, como o já colocado por Benjamin (1994), por sua imediatez e plausibilidade, necessita entregar-se inteiramente ao momento e explicar-se nele, enquanto a narrativa evanesce diante das limitações de uma explicação com pretensões de "significado oficial" ou ainda diante de uma fórmula definitiva em termos de composição.

Textos narrativos estão entre as formas mais ricas de representação humana, ditar um conjunto de prescrições para a determinação do texto narrativo acabaria não só por empobrecer as possibilidades de expressão como também destituiria de valor a maneira mais comum de comunicação entre pessoas, povos e épocas. Cercar a narrativa com normas seria o mesmo que retirar a voz de identidades, tradições e culturas desenvolvidas ao longo dos séculos, seria calar a vida simbólica que floresceu entre os seres humanos. A forma narrativa necessita, imperativamente, de um espaço definidor aberto no qual decante e se conserve o cerne identitário-cultural das organizações humanas ao redor do mundo e ao longo dos tempos.

\subsubsection{A Narratividade como Forma de Pensamento}

Com base no brevíssimo retrospecto histórico compreendido anteriormente, foi possível constatar que as narrativas gregas antigas, as narrativas fundadoras da tradição bíblica e as narrativas medievais tradicionais sustentavam-se sobre três pilares principais: forte caráter figurativo, formativo e exemplar; eixo cronológico mais ou menos linear; modalidade de realização através da oralidade ou da fala.

Muito mais forte do que os mencionados três pilares, existe, nas narrativas observadas, uma atmosfera anímica mágica extremamente sedutora, o que distancia a narrativa da filosofia, muito mais abstrata. 
Em termos um pouco mais concretos, essa força anímica da qual a narrativa é imbuída trata da possibilidade de produzir um impacto afetivo de tal forma que o interlocutor se sinta desequilibrado. Tal desequilíbrio faz com que o interlocutor invista considerável quantidade de energia em uma ação reflexiva restauradora, no intuito de recuperar o seu estado de equilíbrio anterior. Ao se reestabelecer o equilíbrio, observase que, de maneira alguma, esse novo equilíbrio é o mesmo estado de equilíbrio inicial, houve uma aprendizagem e, portanto, uma alteração no interlocutor da narrativa, este nunca mais será como antes. Em outras palavras, o caráter anímico da narrativa é o que coloca em funcionamento a narratividade, um processo de pensamento e, portanto, de aprendizagem, que reproduz a estrutura narrativa, e coloca o ser vivente no exercício de sua própria vida, não apenas como fluxo concreto de ações sobre o mundo, mas, sobretudo, como forma de pensamento e aprendizagem.

Essa reflexão e aprendizagem resultante da narratividade é o que Lev Semyonovich Vygotsky define como perejivânia.

De acordo com Toassa e Souza (2010), a palavra do português que mais se aproxima da síntese vygotskyana perejivânia é a palavra "vivência" na medida em que perejivânia mantém uma relação etimológica com os verbos russos “пережйть” (perejit) е “жить” (jit) que significam "viver". Para Toassa e Souza, “a vivência é campo de conflitos, entreposto do funcionamento psíquico concreto, linguagem do impacto vital do entorno no sujeito." (TOASSA; SOUZA, 2010. p.771). Por essa perspectiva, trata-se de uma ocasião experimentada no exterior do sujeito, no seu meio, que provoca um impacto vital com implicações afetivas, um conflito intelecto-emotivo que resulta em uma mudança interior significativa, que, por sua vez, coloca o sujeito em processo de reflexão até que o mencionado impacto e a mudança, resultante deste, sejam traduzidos em linguagem.

$\mathrm{O}$ ato final dessa aprendizagem por uma perspectiva narrativa, a tradução linguística, a síntese de todo o processo em significação linguística, ou seja, em uma nomeação, é o que se define aqui como ressignificação. É importante destacar que essa ressignificação, esse ato de nomear não se trata, apenas, de uma ocorrência lexical. A ressignificação, assim como a perejivânia, resulta de um processo dado ao longo do tempo, ou seja, resulta de um desenvolvimento narrativo, seja ele uma rememoração, uma releitura, uma reestruturação de um fato vivido ou a pura especulação, ordenada cronologicamente em torno de algo que se busca compreender. Embora a precisão lexical seja fundamental, ela é o início ou o fim do processo, aquilo que desperta para a 
reflexão narrativa ou aquilo que sintetiza todo o processo em forma racional e consciente.

Vale a consideração acerca do fato de que todo esse movimento narrativo, partindo de uma nomeação ou a ela chegando através de um esforço de síntese, é apenas parte do grandioso universo que observamos sob o nome de humanidade. O esforço humano na busca por uma vivência profunda e a sua tradução em termos racionais não implica a não existência do inominável. O ser humano é muito mais do que se pode nomear. Há vastíssimo horizonte de ação humana que extrapola o que se pode delinear em termos racionais. Existe, dentro de cada um dos seres viventes, um universo inaudito, do qual não trataremos no presente estudo ${ }^{8}$, mas que é forçoso mencionar dada a sua importância para a consideração da questão humana. O inominável traz para a constituição do humano a humildade característica daquele que não é senhor absoluto dos próprios atos. Esse universo é o que a psicanálise nomeou como inconsciente, é o solo fértil sobre o qual florescem os desejos, os sonhos, os medos, as manifestações artísticas, as alegrias, as angústias etc. É através dessa dimensão inominável que podemos sentir o impacto afetivo proveniente da força anímica da narrativa e que nos coloca em movimento, seja de forma especulativa, seja na experiência da vida, em busca de sínteses linguísticas, de nomeação e/ou (re)significação.

Conjuntamente a esse caráter anímico, a narrativa hebraica trouxe à luz o uso ploclamativo, a possibilidade de certa interatividade entre o interlocutor e a obra lida na qual o interlocutor preenche as "lacunas" deixadas no enredo com elementos referentes à sua própria experiência prévia, a própria vida do interlocutor toma parte na narrativa. O uso proclamativo inaugura, assim, a possibilidade de certa polifonia no entendimento da narrativa. Orlandi (2008) vai explorar as variadas possibilidades de compreensão que um leitor pode construir diante de determinado texto tendo como pontos de ancoragem para a construção dos sentidos na leitura a sua experiência de vida, suas leituras de mundo, a construção de um aparato teórico metodológico para a realização da leitura propriamente etc. Rouxel (2012) trabalha no mesmo sentido ao afirmar a polissemia da leitura em relação às leituras pessoais, à necessidade de acolher os sentimentos dos leitores em relação à leitura. Na medida em que nenhum ser humano possui o mesmo repertório prévio, as "lacunas" deixadas podem ser preenchidas com os elementos mais diversos, produzindo compreensões e interpretações as mais diversificadas. Quanto

\footnotetext{
${ }^{8}$ A questão do inominável em relação à humanização será objeto de estudos futuros.
} 
mais o interlocutor da narrativa interage com esta, inserindo elementos relativos à própria experiência, mais ele se identifica, mais a narrativa fala à sua essência e, portanto, maior proporção toma o caráter anímico.

Além do uso proclamantivo, a narrativa hebraica ainda revelou, de maneira extremamente insipiente, algumas possibilidades em torno do registro escrito que pode libertar o interlocutor das limitações interpretativas resultantes de uma realização oral imediata e conduzida pelo falante. Essa libertação em termos interpretativos acaba por potencializar a polifonia.

Vale ainda a importante observação de que as narrativas gregas antigas, as narrativas fundadoras da tradição bíblica e as narrativas medievais tradicionais, por sua realização nas modalidades oral ou falada, incentivavam o encontro dos interlocutores no mesmo local e em um mesmo tempo, garantindo o espaço de presença e atuação.

$\mathrm{Na}$ pós-medievalidade, a alteração do modo de produção artesanal para o industrial resultou, como visto anteriormente, no refúgio do ser humano na realidade privada, o que acabou por reduzir a esfera da presença e da atuação do ser humano e, consequentemente, por evidenciar uma dimensão reflexiva introspectiva mais profunda. O homem entra em estado de cisão entre o seu universo especulativo interior e a dimensão mais concreta de atuação sobre o mundo exterior. Inaugura-se um período no qual a narratividade, tanto como ação sobre o mundo concreto quanto como processo de pensamento, é paulatinamente substituída por outros processos especulativos mais abstratos $^{9}$. Do desequilíbrio entre a esfera da vivência, em termos vygotskyanos, e o da especulação mais abstrata surge algo como um processo de asfixia da narratividade, de suspensão do aspecto fluídico, do movimento que caracteriza a vida humana em seu pleno exercício.

A contemporaneidade vem coroar a asfixia da narratividade com a retomada sinérgica da informação e do neotribalismo. A informação, completamente avessa à narratividade por seu caráter imediato e por sua necessidade de plausibilidade, acaba reduzindo o tempo necessário à ponderação em relação ao que é informado. $O$ neotribalismo, por reunir indivíduos sob os mais variados interesses, acaba por justificar o narrative turnning, uma explosão, sobretudo em termos de consumo e submissão, do uso da narrativa de maneira descaracterizada, não como um objeto artístico, dotado de

\footnotetext{
${ }^{9}$ A observação da "concorrência" e/ou da instalação e desenvolvimento de determinada substituição entre os mencionados processos especulativos mais estáticos e o pensamento com base na narratividade será objeto de estudos posteriores.
} 
seu poder anímico, capaz de dar início aos processos implicados na perejivânia, mas como um procedimento manipulador.

Por outro lado, a mesma conectividade que proporciona o aumento do ritmo necessário à imediatez da informação e a explosão do narrative turnning também proporciona um enriquecimento das formas de linguagem. A hipermídia, associada à sinergia contemporânea, não apenas retoma as formas antigas da narrativa como as traduz e as atualiza através de novas linguagens. Conforme Cunha (2009), o desafio, agora, é a descoberta e a elaboração de novas sintaxes, novas maneiras de leitura capazes de chegar ao aprimoramento da capacidade simbólica humana.

Não se trata, absolutamente, de afirmar uma supremacia da narratividade como forma de pensamento e como exercício absoluto das possíveis formas de vida, trata-se de observar um desequilíbrio entre as formas de pensamento e de experiência que acabaram relegando a narratividade a níveis inapropriados, de maneira que se perde, como o defendido por Agamben, a capacidade de narrar, o reconhecimento da experiência de vida de forma significativa em nome de uma fixação estática, esvaziadora e mórbida.

\subsubsection{Humanização X Desumanização}

Tanto o conceito de humanização como o de desumanização são grandezas consideravelmente difíceis de serem tratadas tanto pela complexidade do que abarcam como pela falta de definição específica acerca dos termos. Nas palavras de Gallian, Ponde e Ruiz:

[...] o que chama atenção em tudo isto é, de maneira geral, a ausência de fundamentos teóricos - históricos e filosóficos, principalmente - nos diversos discursos e «práticas» de humanização. Quase sempre, considera-se como óbvio que o que se entende por humanização seja o desenvolvimento de ações e atitudes que redundem numa melhoria das relações dos profissionais da saúde entre si e destes com seus pacientes, o que implica em maior respeito, consideração, atenção, enfim, uma maior humanidade. (GALLIAN; PONDE; RUIZ, 2012. p. 8)

De acordo com essa primeira colocação de Gallian, Ponde e Ruiz, observa-se que é difícil tratar da humanização por falta de elaborações mais pontuais, geralmente, a humanização é encarada como algo trivial, óbvio, para usar o termo dos autores mencionados. Essa concepção inicial acaba por limitar os estudos acerca da 
humanização a definições mais imediatas, que apenas elencam itens. Observe a definição de Candido, constante em $O$ direito à literatura acerca do termo em exame:

\begin{abstract}
Entendo aqui por humanização (já que tenho falado tanto nela) o processo que confirma no homem aqueles traços que reputamos essenciais como o exercício da reflexão, a aquisição do saber, a boa disposição para com o próximo, o afinamento das emoções, a capacidade de penetrar nos problemas da vida, o senso da beleza, a percepção da complexidade do mundo e dos seres, o cultivo do humor. A literatura desenvolve em nós a quota de humanidade na medida em que nos torna mais compreensivos e abertos para a natureza, a sociedade, o semelhante. (CANDIDO, 1995. p. 180. Grifo nosso)
\end{abstract}

Muito embora Candido mencione um processo, e ele reconheça a literatura como uma via para o desenvolvimento de tal processo, a definição, a síntese em relação ao que seja a humanização mantém seu centro em condutas e qualificativos resultantes desse processo. O foco se mantém no objetivo e perde-se o andamento, perde-se, justamente, o "como" se chegar a tais objetivos. Muito mais do que um rol de características e condutas, a humanização implica, em si mesma, um processo narrativo, a humanização implica, invariavelmente, ação, movimento, fluxo no tempo.

Contudo, a afirmação anterior, acerca do foco nos elementos finais do processo, é verdadeira apenas se considerarmos a síntese, a definição do termo "humanização" desenvolvida por Candido. Um pouco antes, no mesmo $O$ direito à literatura, Candido afirma:

Toda obra literária é antes de mais nada uma espécie de objeto, de objeto construído; e é grande o poder humanizador desta construção, enquanto construção. De fato, quando elaboram uma estrutura, o poeta ou o narrador nos propõem um modelo de coerência, gerado pela força da palavra organizada. Se fosse possível abstrair o sentido e pensar nas palavras como tijolos de uma construção, eu diria que esses tijolos representam um modo de organizar a matéria, e que enquanto organização eles exercem papel ordenador sobre a nossa mente. Quer percebamos claramente ou não, o caráter de coisa organizada da obra literária torna-se um fator que nos deixa mais capazes de ordenar a nossa própria mente e sentimentos; e, em consequência, mais capazes de organizar a visão que temos do mundo. Por isso, um poema hermético, de entendimento difícil, sem nenhuma alusão tangível à realidade do espírito ou do mundo, pode funcionar neste sentido, pelo fato de ser um tipo de ordem sugerindo um modelo de superação do caos. A produção literária tira as palavras do nada e as dispõe como todo articulado, Este é o primeiro nível humanizador, ao contrário do que geralmente se pensa. A organização da palavra comunica-se ao nosso espírito e o leva, primeiro, a se organizar; em seguida, a organizar o mundo. Isto ocorre desde as formas mais simples, como a quadrinha, provérbio, a história de bichos, que sintetizam a experiência e a reduzem a sugestão, norma, conselho ou simples espetáculo mental. (CANDIDO, 1995. p. 177.Grifo do autor) 
De modo bem diverso, no trecho acima, Candido estabelece uma elaboração em relação ao processo de humanização, destacando a obra literária, seja ela narrativa ou lírica, como um elemento ordenador ${ }^{10}$, organizando o leitor em suas reflexões e, posteriormente, a visão desse leitor em relação ao mundo que o cerca. Observe o destaque de Candido para o poder humanizador da obra literária "enquanto construção" (CANDIDO, 1995. p. 177): a forma constitutiva da obra literária, como modelo de coerência, empresta as ligações de sua estrutura para a ordenação reflexiva do leitor e de sua visão de mundo, assim como o mencionado na narratividade como forma de pensamento e na perejivânia de Vygotsky.

Assim, um ponto de partida possível para a concepção do que seja a humanização é, novamente, a perspectiva histórica, a observação da dinâmica narrativa do termo ao longo do tempo, de forma que se possa procurar, em tal arranjo estruturante, uma ordenação, mesmo que inicial, para o termo.

O termo humanização, como a descrição do processo de tornar-se humano, relaciona-se com o termo humanidades que, por sua vez, tem sua origem na palavra latina humanitas que nomeava os princípios orientadores da formação latina. Assim como arete e ethos norteavam a formação do homem grego antigo em torno de valores tais como a nobreza de espírito, a valorização de grandes feitos e a cortesia sem precedentes, humanitas concentrava em si valores tais como a polidez de costumes e a civilização. No renascimento, estudiosos buscaram recuperar o conjunto de valores reunidos sob o conceito de humanitas. A esses estudiosos coube o qualificativo de humanistas. Era, então, um humanista aquele que, por alguma forma, buscava resgatar a humanitas latina antiga. Num primeiro momento, essa retomada deu origem a um movimento reflexivo que considerava os mais variados campos de produção humana: arte, ciência, filosofia, teologia entre outros. É apenas em meados do século XVII que os humanistas passam a se especializar em cada um dos campos que tratavam.

Será, entretanto, apenas nos inícios do século XIX, quando do grande
processo de reestruturação das universidades europeias, que o termo
humanidades iria aparecer para designar o conjunto de saberes e disciplinas
que se arregimentavam fora do campo das ciências. Porém, num contexto
de progressivo crescimento do prestígio da visão científica do mundo e do
homem, as humanidades, enquanto «salvaguarda» de um «outro» saber,

\footnotetext{
${ }^{10}$ No subtítulo Justificativa: Mas Por Que a Narrativa?, haverá uma consideração um pouco mais detida acerca das possibilidades de humanização em relação a outros gêneros e a comparação destes com a narrativa.
} 
relacionado com a intuição e a tradição e não tanto com a razão e a experiência empírica, vão, rapidamente, como bem aponta Ortega y Gasset, em ensaio sobre A Missão da Universidade (1999), desaparecendo do horizonte da educação, até reduzirem-se, nos currículos universitários, a disciplinas de «cultura geral», «último e triste resíduo de alguma coisa maior e mais importante». (GALLIAN; PONDE; RUIZ, 2012. p. 9 - 10. Grifo nosso)

Observa-se, assim, o percurso do termo humanidades iniciando com um movimento de resgate da humanitas latina e o seu declínio por um desajuste de seus métodos de observação e reflexão diante do método científico em voga. Com esse declínio, surgem as ciências humanas e sociais, uma tentativa de versar acerca dos temas tratados pelas humanidades, porém, pela perspectiva cartesiana de observação e experimentação do mundo. Enquanto as ciências humanas e sociais se rendem ao método científico das ciências exatas e biológicas, as humanidades ficam, então, relegadas ao entretenimento e ao devaneio.

[...] as Humanidades identificam-se agora muito mais com exercícios e vôos da imaginação do que com saber efetivo, seguro, prático e socialmente útil. $\mathrm{Na}$ nova divisão hierárquica das práticas e saberes humanos imposta pela Modernidade, coube às Humanidades o «território da cultura», entendida aqui fundamentalmente como «entretenimento», «diversão», complemento ou verniz estético — útil apenas na medida em que pode ser transformado em mercadoria e ser consumido num mercado, cada vez mais ávido de compensações sensoriais, emocionais e oníricas-. Conhecimento prático e útil é fruto das Ciências; das Humanidades espera-se apenas devaneio ou reflexão, indispensáveis sem dúvida para a existência humana, porém num grau muito menos importante do que o conhecimento científico-tecnológico. (GALLIAN; PONDE; RUIZ, 2012. p. 10)

Para além dessa perspectiva que considera as humanidades como uma esfera de satisfação sensorial, emotiva e onírica, o movimento de resgate da humanitas no renascimento também levou a outra compreensão do termo humanidades, uma compreensão algo mais filosófica que trouxe à luz o conceito de perfectibilidade, ideia que afirma a:

[...] suficiência e autonomia da natureza humana, materializadas numa razão e vontade perfectíveis. Desdobra-se daí a ideia de que a natureza humana contém em si todos os elementos necessários e suficientes para realizar sua vida em movimento de autoaperfeiçoamento contínuo e crescente (nos campos moral, político, técnico e epistêmico). (GALLIAN; PONDE; RUIZ, 2012. p. 10). 
Eis aí, a fonte inicial do racionalismo. Uma série de grandes pensadores opôs-se ao desenvolvimento do pensamento ancorado sobre a ideia da perfectibilidade, no entanto, há certo desentendimento entre os adeptos da perfectibilidade e seus críticos, pois aqueles parecem entender que a não afirmação da perfectibilidade acaba impedido o potencial humano de desenvolvimento e aprendizagem:

\begin{abstract}
A importância que ganhou a «tese da perfectibilidade» para o imaginário moderno foi tão grande que as críticas consistentes a ela feitas desde o século XVI não receberam a devida atenção enquanto críticas à perfectibilidade em si mesma. Assim, tal movimento termina por causar uma espécie de mentira antropológica de fundo: criticar a perfectibilidade significaria ferir a autoestima do ser humano, e por isso seria necessário calar sobre as hipóteses críticas que a filosofia (teologia e literatura) produziu desde então. Tal perspectiva se apropriou do conceito de humanismo, normatizando o seu uso e referenciando o discurso moderno da humanização. (GALLIAN; PONDE; RUIZ, 2012. p. 11. Grifo nosso.)
\end{abstract}

A partir de então, o humanismo passa a se relacionar de forma tão intensa com a perfectibilidade, que muito dificilmente podem ser considerados separadamente. A sólida e equivocada conjunção entre humanismo e perfectibilidade acabou lançando bases para a edificação da desumanização na medida em que a perfectibilidade afirma total e completa confiança na edificação do progresso sobre as bases das ciências exatas e naturais, do método cartesiano, do racionalismo e da retidão moral humana.

O tempo passa e, atualmente, constata-se, pelos olhos da tecnologia da informação, que toda a confiança da perfectibilidade depositada nas potencialidades dos seres humanos não foi capaz de conduzir a humanidade a um mundo mais igualitário e justo. Pelo contrário, o homem, em sua imperfectibilidade, acabou lançando mão de seu racionalismo e das ciências para concentrar recursos, tecnologias e confortos em torno de si, construindo o "império do eu" diante da miséria do outro. O desmoronamento da crença na perfectibilidade do humanismo acabou gerando frustração, decepção e fatalismo em escala mundial. Se toda a esperança colocada nas capacidades e nas potencialidades dos seres humanos "falharam" o que poderia, então, dar certo? Ao tentar descrever tal angústia, Izabel Cristina Rios, em Caminhos da humanização na saúde: prática e reflexão, afirma:

Desabaram os ideais utópicos, políticos, éticos e estéticos da modernidade que creditavam ao projeto iluminista a construção de um mundo melhor, movido pela razão humana. As pessoas, cada vez mais descrentes da política e das ideias revolucionárias que, na prática, deram poder a governos corruptos e incapazes de promover o bem da nação, não buscaram mais 
seus referenciais de identificação nos grandes coletivos sociais, mas sim em si mesmas. Para certos autores, essa é uma das principais características do que eles chamam de época hipermoderna ou supermoderna: a figura do excesso e da deformação notadamente no que se refere ao "eu". (RIOS, 2009. p. 8. Grifo nosso)

A partir do momento em que o ser humano se desilude das realizações através da ação dos "coletivos" como menciona Rios, e passa a investir, de forma extremamente narcísica, sua energia apenas em si mesmo, em suas realizações individuais, pessoais, e subjetivas, a vida se reduz para muito além do esvaziamento da experiência como o proposto por Agamben, o sujeito se afasta do contato com outros através da experiência e está edificada a fonte maior para o desenvolvimento da desumanização.

Por mais que essa perspectiva histórica fundamente uma elaboração em torno dos processos de humanização e desumanização, falta um conceito para o humano em si. Nesse sentido, Fabiana Carelli, seguindo a trilha da narratividade, vai à busca de uma possível sistematização do termo humano sobre as bases do homo narrativus. Para Carelli:

\footnotetext{
Assim compreendido o ser humano não é fictus, mas essencialmente narrativus: ser $\underline{n o}$ tempo que, ao descobrir sentidos e imaginar possibilidades cria um mundo e, assim, cria a si próprio - exercício da existência que é sempre possibilitado e potencializado pela prática de, concreta e ficcionalmente, contar(-se). (CARELLI, 2016. p. 46. Itálicos e sublinhado da autora)
}

Note que tanto o termo humanização quanto a concepção do homo narrativus estão fortemente embasadas sobre o solo semântico da narratividade. Ambos pulsam um desejo de fluxo, há uma força que conduz ao movimento, à ação ao longo do tempo. É possível que a dificuldade de definição esteja justamente aí: ao tentar capturar, em um conceito estático, o que seria a humanização e/ou o humano, perde-se a sua essência definidora que está, fractalmente, solidificada sobre a fluidez da ação, sobre a dinâmica da narratividade. A humanização é algo que não se pode conceber em termos estáticos e que evanesce diante de qualquer tentativa de asfixia conceitual. Em outras palavras, a humanização deve ser, não definida, mas narrada, narrada nas palavras de cada um dos seres viventes que a experimentam, que a vivenciam. Há tantos processos de humanização quanto há seres humanos que refletem acerca de suas trajetórias e se mostram dispostos a contá-las. Humanização é o reconhecimento, no próprio ser, do desenvolvimento da vida tanto em dimensões reflexivas quanto ativas. 
Até aqui, foi possível observar a aproximação da essência do termo humano e, por extensão, da humanização com o fluxo, o movimento da narratividade não apenas em termos de experiência concreta sobre o mundo, mas, sobretudo, em termos de pensamento, no reconhecimento da experiência como forma narrativa, do contar(-se). Já a desumanização tende à asfixia da ação e à perda de espaço de presença e atuação do ser vivente, seja pelo recolhimento do homem moderno em sua realidade privada, seja pela alteração do ritmo de produção imposto a partir da modernidade (como o visto anteriormente), ou ainda, pelo colapso da confiança na ideia da perfectibilidade e, posteriormente, nos coletivos de ação. Trata-se de uma experiência muito mais pautada sobre a inércia, a paralisia que impede o reconhecimento da experiência de forma significativa por um viés narrativo ${ }^{11}$. As coisas não se sucedem, os fatos não fluem, instaura-se uma fixação mórbida, estabelecida sobre ciclos tediosos em torno de pontos de aderência que esvaziam a significação e o sentimento de vida.

\subsubsection{O problema: A asfixia da Narrativa}

Conforme se instaurou o recolhimento do ser humano na esfera privada, iniciou-se por perder o espaço de atuação e de presença do ser humano no ambiente público assim como a confiança na ação dos coletivos. A narratividade, tanto como processo de ação concreta sobre o mundo como quanto processo reflexivo, acaba perdendo terreno. Paulatinamente, o ser humano foi perdendo a capacidade de ressignificar, ou seja, de nomear, através de signos, as próprias vivências.

Dante Gallian, em A literatura como remédio: os clássicos e a saúde da alma, na esteira de Antoine Compagnon, afirma que a incapacidade de nomear invade a realidade humana como uma doença diante da qual, o melhor antídoto é a literatura:

[...] na perspectiva iluminista e romântica a literatura se apresenta como remédio e antídoto contra a fragmentação da experiência subjetiva provocada pelo desenraizamento e pela divisão do trabalho na sociedade industrial, na perspectiva moderna ou modernista, como coloca Compagnon, a literatura aparece como remédio contra "os defeitos da linguagem". Isto é, num mundo em que a cultura vai se tonando cada vez mais técnica e instrumental, a linguagem tende a se tornar pobre, utilitária e massificada. Ela deixa de dar conta, por exemplo, de realidades mais amplas e profundas, como a da dimensão dos sentimentos, das intuições, do sublime. Neste sentido, desde

${ }^{11}$ É necessária uma elaboração mais aprofundada acerca de humano, humanização e desumanização, sobretudo, no estabelecimento de uma relação mais íntima entre os termos, o que será objeto de um estudo futuro. 
Mallarmé e Bergson, a literatura se concebe como um remédio não mais para os males da sociedade, mas, essencialmente, para a inadequação da língua. (GALLIAN, 2017. p. 73)

De acordo com Gallian, o vazio deixado pela narrativa implica um vazio na possibilidade de se tratar de sentimentos, de intuições e do sublime. Na incapacidade de se tratar de tais aspectos através da língua, é como se tais elementos passassem a não existir, pois o homem não toma consciência daquilo que ele não nomeia. Muito embora já se tenha mencionado aqui a importância da grandeza inaudita para a constituição do ser humano, tal grandeza é de uma natureza diversa da perda da capacidade de nomear e, portanto, da perda da capacidade de se tratar, de forma consciente e racional, da experiência humana. É justamente essa dimensão inominável que irá se manifestar, de forma dolorosa e angustiante, diante da perda da capacidade de significar, de perceber racionalmente a intensidade da experiência, da vida. Com tal perda, é como se, paulatinamente, fôssemos perdendo a capacidade de ter sentimentos quando paramos de nos referir a eles, de refletir sobre eles e, por fim, de senti-los. A dimensão utilitária e tecnocrata à qual nos submetemos é, de fato, tão poderosa, que terminou por possibilitar, ao menosprezarmos os caracteres humanos, que estes fossem, lentamente, asfixiados e mortos dentro de nós. Na impossibilidade de se tratar de suas angústias, na impossibilidade de se manifestar e refletir sobre aquilo que incomoda ou faz falta, nosso mundo se entregou à frieza das questões utilitárias cartesianas.

Ao perceber que a ausência de uma formação humanística já tinha evoluído a tal patamar, muitas tentativas foram sendo empreendidas, em várias esferas de atuação institucional, no sentido de empreender um resgate da humanidade. No Brasil, no ano de 2003, instituiu-se a Política Nacional de Humanização - PNH, uma política pública nacional através da qual se busca humanizar o atendimento dos profissionais da saúde do Sistema Único de Saúde - SUS. De acordo com o site oficial do programa os objetivos principais são:

- Contagiar trabalhadores, gestores e usuários do SUS com os princípios e as diretrizes da humanização;

- Fortalecer iniciativas de humanização existentes;

- Desenvolver tecnologias relacionais e de compartilhamento das práticas de gestão e de atenção;

- Aprimorar, ofertar e divulgar estratégias e metodologias de apoio a mudanças sustentáveis dos modelos de atenção e de gestão; 
- Implementar processos de acompanhamento e avaliação, ressaltando saberes gerados no SUS e experiências coletivas bem-sucedidas. (HUMANIZA SUS, 2003)

Por uma via semelhante, as Diretrizes Curriculares Nacionais do Curso de Graduação em Medicina, Resolução CNE/CES no 4, de 7 de novembro de 2001, defendem a necessidade de implementação de uma formação humanística ante a esses futuros profissionais. Em seu artigo $3^{\circ}$, as diretrizes apresentam um perfil do profissional formado em medicina que inclui uma formação humanística:

Art. $3^{\circ}$ O Curso de Graduação em Medicina tem como perfil do formando egresso/profissional o médico, com formação generalista, humanista, crítica e reflexiva, capacitado a atuar, pautado em princípios éticos, no processo de saúde-doença em seus diferentes níveis de atenção, com ações de promoção, prevenção, recuperação e reabilitação à saúde, na perspectiva da integralidade da assistência, com senso de responsabilidade social e compromisso com a cidadania, como promotor da saúde integral do ser humano. (MEC, 2001. p. 1. Grifo nosso)

O mesmo documento, em seu artigo $6^{\circ}$, inciso IV, trata da necessidade de considerar aspectos humanísticos na relação médico-paciente:

IV - compreensão e domínio da propedêutica médica - capacidade de realizar história clínica, exame físico, conhecimento fisiopatológico dos sinais e sintomas; capacidade reflexiva e compreensão ética, psicológica e humanística da relação médico-paciente; (MEC, 2001. p. 3. Grifo nosso)

Mais do que definir características para um aluno egresso e pontuar a necessidade de considerar a compreensão ética, psicológica e humanística na relação médicopaciente, o documento afirma, ainda, a necessidade dos próprios cursos de formação em medicina assumirem a responsabilidade de fornecer, a seus alunos, a formação humanística tão almejada. É o que defende o inciso III, artigo $12^{\circ}$ da mesma diretriz: “A estrutura do Curso de Graduação em Medicina deve: [...] III - incluir dimensões éticas e humanísticas, desenvolvendo no aluno atitudes e valores orientados para a cidadania" (MEC, 2001. p. 5).

Diante da necessidade legal de prover, aos alunos de medicina, uma formação humanística capaz de melhorar as relações do profissional da saúde com seu público, faculdades e institutos de formação passaram a elaborar cursos de humanização baseados em uma perspectiva prescritiva, ou seja, na exposição de um rol de condutas e atitudes que devem ser executadas diante do paciente. Dante Gallian, Luiz Felipe Ponde e Rafael Ruiz ao analisarem a iniciativa dos "cursos de humanização prescritivos", em 
seu estudo As patologias da modernidade e os remédios das humanidades: investigação e experimentação, concluiram que:

\begin{abstract}
Ao se analisar, entretanto, os resultados de tais abordagens ou programas, levando-se em consideração as opiniões e sentimentos dos que estão sendo treinados ou "educados", percebe-se claramente a sua ineficácia. Havendo perdido o élan com os fundamentos filosóficos e culturais humanísticos, essas novas propostas educacionais, nascidas no seio de uma cultura científico-tecnicista, pretendem "ensinar" ou "incutir" humanismo ou humanidade da mesma forma como ensina e incute habilidades cognitivas e técnicas. Os educandos, por sua vez, encaram todo esse processo como mais um conjunto de conteúdos e técnicas que precisam ser incorporadas, num pacote de "competências" e "habilidades" já demasiadamente pesado e exigente, que, mais do que nada, incrementa a angústia e a ansiedade. Em suma, havendo descuidado o que é ser humano para além das competências e habilidades cognitivas e técnicas, a educação contemporânea, no intuito de humanizar, acaba muitas vezes e paradoxalmente, por contribuir para a desumanização. (GALLIAN; PONDÉ; RUIZ, 2012. p. 8 -9. Grifo nosso.)
\end{abstract}

Ao mesmo tempo em que tais autores observavam a grande controvérsia e fatal ineficácia em se tratar de elementos essencialmente humanos como técnica, Dante Gallian passou a constatar um potencial efetivamente humanizador junto ao seu Laboratório de Humanidades - LabHum, uma iniciativa resultante do sucesso das discussões de textos narrativos ficcionais no curso de formação em medicina da Universidade Federal de São Paulo - UNIFESP.

Diante do sucesso da experiência de Gallian ao levar uma formação humanística baseada na leitura e reflexão de narrativas ficcionais ante aos alunos de medicina, outras instituições demonstraram interesse em relação ao experimento.

Duas experiências, entretanto, foram decisivas para que este experimento humanizador transcendesse os campos estritamente acadêmicos e da saúde e começasse a se desenvolver tanto no cenário do mundo corporativo quanto no da sociedade de forma mais ampla. A primeira experiência se deu graças ao interesse que a proposta do LabHum suscitou num diretor da área de recursos humanos de uma grande empresa de cosméticos: a Natura. [...] A segunda decisiva experiência se deu no âmbito da difusão cultural junto à sociedade em geral. Sendo eu convidado a ministrar ocasionalmente cursos da área de humanidades na Casa do Saber em São Paulo [...] (GALLIAN, 2017. p. 53 - 54)

O interesse corporativo pela experiência da formação humanística revela a importância e a necessidade das organizações em relação ao desenvolvimento de aspectos humanos tanto no trato do profissional com sua clientela, como também entre os profissionais nas relações interiores às companhias. 
Se o emprego da narrativa tem se mostrado tão bem vindo e bem sucedido no interior das empresas e da faculdade de medicina, por que não observar e adaptar o emprego da formação humanística através da narrativa no meio escolar? A escola, assim como qualquer outra instituição, padece com a falta de um programa de formação humanística de qualidade, especialmente concebido a seus integrantes e que forneça, já no princípio da vida escolar, um desenvolvimento humano, um processo de humanização realmente sólido, sobre os quais o aluno pode desenvolver seus valores e posturas, tornando-se um adulto bem preparado sob a perspectiva humana.

A narrativa sempre esteve presente nos currículos e no meio escolar propriamente, desde a educação infantil até o ensino médio. No entanto, alunos egressos do ensino fundamental e médio, que vão para o mercado de trabalho, para o funcionalismo público, para as empresas privadas ou para as universidades, demonstram não possuir a formação humanística necessária para o desempenho de suas funções com o devido respeito à concepção humana de seus clientes ou pacientes. Se assim não fosse, instituições de ensino superior e as grandes empresas não deveriam estar preocupadas com o desenvolvimento de programas e experiências que proporcionem a tão necessária formação humanística.

O problema é que a escola, como instituição inserida na realidade tecnicista, acaba por converter a narrativa em um conteúdo raso, reduzido a um objeto que deve ser encarado somente pela perspectiva escolar: deve-se buscar pelo tempo no qual ela se desenvolve, o foco narrativo, os personagens, a definição do problema, seu desenvolvimento até o momento clímax e o desfecho do enredo. Mesmo sem se dar conta, a escola acaba por negligenciar as profundidades interpretativas, a dimensão dos afetos, a esfera propriamente humana presente nas narrativas. Por mais que os documentos oficiais, tais como o Currículo Paulista, o Currículo do Estado de São Paulo, a Base Nacional Comum Curricular e as Diretrizes Básicas da Educação, versem acerca da importância da leitura como fruição, da interpretação em sua profundidade, da inferência e da transposição de significados e sentidos empregados nas metáforas e nas alegorias, tudo isso é negligenciado, seja por dificuldades dos próprios professores em relação à realização de uma leitura mais verticalizada, seja por dificuldade de instalar a possibilidade interpretativa diante dos alunos. Estes estão tão extremamente distanciados das possibilidades de contato e relação mais íntima com a narrativa literária que qualquer interpretação mais profunda diante de um texto é taxada, invariavelmente, como "viagem", como algo aleatório e desprovido de lógica ou coerência. Para os 
alunos, a leitura não é um universo de exploração e de experimentação de sentidos, vivências, reflexões e prazeres, a leitura é uma realidade pronta e interditada, hermeticamente isolada de suas realidades e possibilidades. Caio Meira ${ }^{12}$ em apresentação à edição brasileira do estudo Literatura em perigo de Tzvetan Todorov, afirma:

\begin{abstract}
O perigo mencionado por Todorov não está, portanto, na escassez de bons poetas ou ficcionistas, no esgotamento da produção ou da criação poética, mas na forma como a literatura tem sido oferecida aos jovens, desde a escola primaria até a faculdade: o perigo está no fato de que, por uma estranha inversão, o estudante não entra em contato com a literatura mediante a leitura dos textos literários propriamente ditos, mas com alguma forma de critica, de teoria ou de história literária. Isto é, seu acesso à literatura é mediado pela forma "disciplinar" e institucional. Para esse jovem, literatura passa a ser então muito mais uma matéria escolar a ser aprendida em sua periodização do que um agente de conhecimento sobre o mundo, os homens, as paixões, enfim, sobre sua vida intima e pública. (MEIRA apud TODOROV, 2009. p. 10. Grifo nosso.)
\end{abstract}

As mesmas tendências tecnocratas que fizeram com que os cursos de medicina buscassem ensinar humanização através de métodos prescritivos também empurra a instituição escolar à redução do potencial interpretativo das narrativas em um objeto curricular delimitado e determinado. Nas palavras de Cunha há uma "crença de que o jovem receptor é alguém que sempre necessita da condução protetora do adulto para ser ensinado a criar, a pensar como adulto, a agir como tal [...]. Desse modo, a criação, como possibilidade de orientar a percepção é postergada." (CUNHA, 2009. p. 29).

Por que não oferecer aos alunos o contato direto com narrativas que respeitem as suas possibilidades de interpretação e as experiências de vida já acumuladas por esses alunos? Por que não saborear junto deles todas as possibilidades interpretativas que eles, alunos, podem trazer à luz? Por que não oferecer as narrativas como possibilidades e não como objetos acabados? Por que não explorar a fruição artística ao invés de decorar elementos de uma interpretação pronta, até mesmo artificial para muitos dos alunos, tendo em vista suas realidades e experiências prévias?

São inúmeros os questionamentos que delimitam o problema central do trato com a narrativa e a formação humana na escola, no entanto, o principal deles para o presente estudo é: como utilizar a narrativa para a ampliação dos horizontes interpretativo, criativo e fruitivo, alavancando as possibilidades de formação emocional, social e humana no ambiente escolar?

\footnotetext{
${ }^{12}$ MEIRA, C. Apresentaçao à Ediçao Brasileira. Rio de Janeiro: DIFEL, 2009.
} 


\title{
1.2.5. Justificativa: Mas Por Que a Narrativa?
}

A grande maioria dos povos que espalharam sua existência sobre a Terra registrou o mistério de sua origem e os grandes feitos de seus personagens através de narrativas épicas: os povos indianos conservam os grandiosos poemas Mahabharata e Ramayana; os povos germânicos possuem a Edda; os romanos valeram-se da Eneida; os finlandeses deram origem à Kalevala; povos do sudeste asiático, sobretudo os que habitam, hoje, a região do Vietnam, trouxeram à luz o Conto de Kieu; o tibetanos confabulavam em torno de Rei Gesar; os persas registram seus mitos na Shahnameh; os chineses, no Shi Jing; os hebreus, no Gênesis, no Exodo, em todo o Pentateuco; entre muitos e muitos outros. Mas, por que a épica narrativa?

Theodore W. Adorno (2003) afirma que a forma artística, o gênero através do qual se dá a realização de uma obra literária, nada mais é do que conteúdo sócio-histórico decantado. Não basta apenas ter o que dizer, é necessário dar corpo discursivo a esse algo a ser dito, ou seja, conferir ao que é dito um formato de realização concreto que seja inteligível ao interlocutor. Eis aí o conceito bakhtiniano de "gênero discursivo". De acordo com Bakhtin, “[...] cada campo de utilização da língua elabora seus tipos relativamente estáveis de enunciados, os quais denominamos como gêneros discursivos" (BAKHTIN, 2003, p. 262. Itálicos do autor). Mais adiante, o mesmo autor continua:

\begin{abstract}
Nós aprendemos a moldar nosso discurso em formas de gênero e, quando ouvimos o discurso alheio, já adivinhamos o seu gênero pelas primeiras palavras, adivinhamos um determinado volume (isto é, uma extensão aproximada do conjunto do discurso), uma determinada construção composicional, prevemos o fim, isto é, desde o início temos a sensação do conjunto do discurso que em seguida apenas se diferencia no processo de fala. Se os gêneros do discurso não existissem e nós não os dominássemos, se tivéssemos de criá-los pela primeira vez no processo do discurso, de construir livremente e pela primeira vez cada enunciado, a comunicação discursiva seria quase impossível [...] a diversidade dos gêneros do discurso é muito grande [...] A diversidade desses gêneros é determinada pelo fato de que eles são diferentes em função da situação, da posição social e das relações sociais de reciprocidade entre os participantes da comunicação (BAKHTIN, 2003, p. 283).
\end{abstract}

Têm-se, então, a definição de gênero como uma forma concreta pronta de realização linguística, como uma forma que molda as ideias em algo inteligível ao interlocutor. De acordo com Adorno, observa-se que nesse processo de moldagem, a 
forma do gênero acaba atribuindo às ideias a serem transmitidas algo de sua propriedade como uma determinada extensão, estrutura além de certo tom de formalidade que busca acertar a manifestação das ideias à determinada situação de enunciação. É exatamente isto que vai proporcionar ao gênero vastíssima diversidade, atribuindo, assim, uma série de qualificações às ideias a serem transmitidas. Vale a ressalva acerca do caráter relativamente estável do gênero. Mesmo que a forma atribua certos caracteres ao que é dito, tais caracteres não devem ser tomados como o eixo definidor de determinado gênero, dado que eles se flexibilizam, se atenuam, ou mesmo desaparecem diante das exigências da modalidade de realização, da temática abordada, da situação de enunciação e do interlocutor.

É essa narrativa enquanto gênero, enquanto forma, que cede seu arranjo estrutural ao pensamento humano como elemento organizador de uma realidade. É a estrutura narrativa presente nas obras literárias, sobretudo nas formas narrativas, que converte o real em algo inteligível, cognoscente e, portanto, perceptível à reflexão humana (sem desconsiderar a faceta inominável da condição humana, conforme o já observado anteriormente). Sobre esse empréstimo da forma cognoscente, Candido irá refletir:

\footnotetext{
Hoje sabemos que a integridade da obra não permite adotar nenhuma dessas visões dissociadas; e que só a podemos entender fundindo texto e contexto numa interpretação dialeticamente íntegra, em que tanto o velho ponto de vista que explicava pelos fatores externos, quanto o outro, norteado pela convicção de que a estrutura é virtualmente independente, se combinam como momentos necessários do processo interpretativo. Sabemos, ainda, que o externo [...] importa, não como causa, nem como significado, mas como elemento que desempenha um certo papel na constituição da estrutura, tornando-se, portanto, interno. (CANDIDO, 2010, p. 13-14. Grifo nosso)
}

Considerando, assim, a narrativa como gênero, enquanto forma cognoscente para os processos de humanização, passemos a observá-la sob a perspectiva da modalidade de realização e da temática por ela abarcada, buscando refletir em torno das vantagens da narrativa como gênero fundamental para o empreendimento inicial do processo de humanização.

Em relação à modalidade de realização, observou-se que, a princípio, a narrativa estava associada à realização oral, necessitando da interação face a face entre enunciador e interlocutor. Com o advento da escrita, a narrativa pôde se emancipar do discurso e da condução de um enunciador e alçar voos no vasto horizonte das possibilidades de leitura realizadas por um interlocutor que lê e constrói seus sentidos sozinho. Tal movimento, por mais que possa representar um distanciamento entre 
enunciador e interlocutor, acabou possibilitando maior liberdade ao interlocutor que pode projetar suas experiências na leitura, através do uso proclamativo, e criar um espaço íntimo e legítimo de reflexão sobre a obra lida.

Em relação à temática, pode-se dizer que a narrativa possui um conjunto infinito de itens abordáveis. Tudo o que acontece, que implica ação, pode ser representado através de uma narrativa. Na tentativa de estabelecer um eixo delimitador para a temática narrativa, pode-se dizer que, como o afirmado por Fiorin anteriormente, os temas abordados em narrativas devem oferecer uma transformação: há um estado inicial, um desequilíbrio seguido por um novo equilíbrio, porém, não como o equilíbrio inicial, um equilíbrio revisitado, portador de uma experiência e/ou uma aprendizagem nova, construída em face da instabilidade apresentada e sua resolução (ou não). O tema trabalhado através da ação dos personagens figura um corpo concreto sobre o qual se desenvolve o esquema equilíbrio $\rightarrow$ instabilidade $\rightarrow$ novo equilíbrio, a dinâmica da narratividade que pode ser tanto o reconhecimento de uma forma de agir sobre o mundo quanto uma forma de pensamento e aprendizagem.

A poderosa associação entre desequilíbrio, enfrentamento e resolução (ou não) de uma instabilidade com a concretude figurativa da narrativa faz dela o gênero inicial por excelência para a instalação do processo de humanização, dado que a própria humanização é entendida como uma dinâmica narrativa, como processos reflexivos fundamentados sobre a narratividade. É a narrativa que empresta a sua forma para o desenvolvimento e a organização da humanização, dado que esta tem em si o desenvolvimento de um percurso narrativo. Assim foi como o visto com a ressignificação, a perejivânia vygotskyana e assim é com o conceito, algo mais existencial, de resiliência humana, cunhado por Fabiana Prando em sua dissertação de mestrado intitulada como Narrativa e Resiliência: a invenção de si.

O conceito de resiliência narrativa pressupõe uma configuração narrativa da vida, um olhar que elabore e reelabore os sentidos da existência por meio de uma organização análoga aos padrões ficcionais. A capacidade de ler, configurar e reconfigurar as experiências vividas pelos modelos da literatura favorece sobremaneira essa prática. [...] A resiliência narrativa é a capacidade de fazer sentido a partir da falta de sentido. Ao cunhar o conceito de "resiliência narrativa", ousamos propor um diálogo entre a resiliência de Cyrulnik e o imbricamento concebido por Paul Ricoeur entre mundo do texto e experiência de vida. Concebemos a resiliência narrativa como a capacidade de, pela via narrativa (criando, lendo ou adaptando histórias), construir sentido a partir da falta de sentido. (PRANDO, 2019. p. 33 - 34. Grifo nosso) 
A narrativa humaniza, sobretudo, pela oportunidade de construir sentido, de introduzir na mente humana grandezas e formas que passam a compor a rede de relações de pensamento, proporcionando um refino deste, através do qual se concebe panoramas interpretativos cada vez mais complexo e liberta de uma visão simplista e imediata. A instauração desse processo de refino do pensamento é, ainda, prazerosa, confluindo aspectos lúdicos, a experimentação estética e o potencial anímico.

Considerando a experimentação estética e o potencial anímico, presentes na narrativa, como uma fonte de energia a impulsionar o leitor aos processos de reflexão individual e tomada de decisão, é importante ressaltar o aspecto ativo da experimentação estética. De acordo com Maria Zilda da Cunha, mencionando Lucia Santaella:

\footnotetext{
A contemplação estética, como já esclarecido, não é uma contemplação passiva, pelo contrário, é uma contemplação ativa há um fisgamento e um entendimento que nos atraem e nos cativam. Há uma razão que borbulha com o sentimento. A suspensão do policiamento da racionalidade, a pura inocência dos sentidos é fundamental para o estado mental estético, "mas isso não significa que a razão criativa não entre também em operação para compreender o sentimento". (CUNHA, 2009. p. 52)
}

A vivência do sentimento estético implica, invariavelmente, um percurso ativo, um desenvolvimento que, cada vez mais, se vê relegado a uma importância secundária. O não desenvolvimento desse percurso acaba abandonando o ser humano a um desenvolvimento racional cada vez mais frágil. $\mathrm{O}$ aluno em tal situação cresce e se torna um adulto com uma capacidade reflexiva demasiada simplista e ingênua, não sendo capaz de acompanhar um raciocínio um pouco mais complexo, enxergar um pouco mais além de consequências mais imediatas. $\mathrm{O}$ adulto em tal situação acaba por formar suas opiniões e tomar suas atitudes baseando-se sobre fundamentos extremamente parcos e escassos, sem poder antecipar consequências mais graves de seus próprios atos, apoiando discursos extremistas, justificando atos violentos entre outras graves consequências.

Embora compreenda-se a supremacia cronológica da narrativa no empreendimento do processo de humanização, e a força de tal gênero no sentido de acionar processos reflexivos racionais ativos, desenvolvendo a capacidade intelectual reflexiva, despertando o leitor para um olhar mais apurado, complexo e abrangente, isso não retira de outros gêneros a possibilidade de humanizar. Afirma-se a supremacia da narrativa por uma perspectiva cronológica, pela importância das narrativas de fundação 
presentes em todas as civilizações e pela concretude de seu caráter figurativo capaz de dar início ao fluxo de energia que conduz à experimentação estética e aos processos reflexivos; por seu caráter anímico e por sua semelhança com o processo de pensamento e aprendizagem significativos da perejivânia. Deve-se estudar as possibilidades de humanização associadas a outros gêneros, de forma que os textos literários produzidos por mãos humanas assegurem nossa essência humana e o resgate de capacidade de nossos caracteres basilares fundamentais, como a capacidade de sensibilização diante do processo de desumanização.

Compreendendo, assim, a instalação de um ambiente íntimo e legítimo de reflexão no leitor, associado à concretude figurativa e à transformação presentes no gênero narrativo, constata-se a supremacia inicial do gênero narrativo para a introdução do leitor no processo de humanização, sem excluir, obviamente, a possibilidade de humanização advinda de outros gêneros. 


\section{Metodologia e Proposta de Intervenção Pedagógica}

Partindo da proposta de Dante Gallian para a realização do Laboratório de Leitura - LabLei, levando em consideração as premissas por ele colocadas no intuito de realizar uma adaptação destas para o contexto escolar e considerando também todo o percurso histórico traçado no presente estudo, evidenciando a importância da narrativa no processo de humanização, elaborou-se uma proposta de atividade a ser desenvolvida diante de uma sala de nono ano do Ensino Fundamental II, em uma escola estadual situada na periferia da cidade de Mogi das Cruzes, no distrito de Jundiapeba: a Escola Estadual Professora Maria Isabel dos Santos Mello.

\subsection{O Público Alvo}

O distrito de Jundiapeba destaca-se por ser uma localidade de carência bastante evidente. Embora a região seja atendida por instrumentos institucionais públicos tais como escolas e postos de saúde ainda falta muito no sentido de atender a população local. Crianças e jovens, após o período em que estão na escola, ficam entregues ao ócio, não há investimentos no sentido de proporcionar uma atividade esportiva, cursos para formação complementar ou qualquer tipo de atividade extraescolar. Entregues ao ócio, as crianças se tornam um alvo fácil para a ação do crime organizado.

Excetuando esses alunos que ficam o período da tarde entregues ao ócio, há, na sala em questão, um outro perfil de alunos que, desde muito cedo, são solicitados a ajudar na renda familiar. Essas crianças trabalham como coletores de material para um ferro-velho da região ou em hortas familiares, no plantio, cultivo e colheita de itens alimentícios a serem vendidos na feira do bairro.

Sob o ponto de vista familiar, muitos dos alunos do nono ano observado pertencem a famílias muito humildes. A maioria das mães são donas de casa, diaristas em casas na região central da cidade ou vendedoras em pequenos estabelecimentos de comércio local (bombonieres, bares e pequenas lojas de revenda de roupas adquiridas na região central de São Paulo). Os pais são operários na indústria de papel e celulose da região, prestadores de serviços gerais, pedreiros, caminhoneiros ou encontram-se desempregados. Há ainda considerável parcela dos alunos cujos pais trabalham na zona rural do distrito e na feira, que se realiza três vezes por semana. Sobre o nível de escolarização dos pais, pode-se afirmar que a maioria não possui o ensino fundamental 
completo, alguns poucos pais buscam terminar os estudos frequentando a Educação de Jovens e Adultos, oferecida pela mesma unidade escolar em questão.

A maioria dessas famílias não oferecem às suas crianças o acesso, nem mesmo o contato com elementos da cultura letrada tais como livros, revistas, jornais ou qualquer outro material escrito. O contato inicial dessas crianças como as mídias impressas se realiza a partir da educação infantil nas escolas municipais da região ${ }^{13}$ através dos CEDIC's - Centro de Divulgação e Construção do Conhecimento, trata-se de uma biblioteca multimídia na qual os alunos não apenas manuseiam variados materiais de mídia impressa como também têm acesso à outras mídias como CD's musicais, DVD's infanto-juvenis, brinquedos e jogos. Muito embora o CEDIC tenha uma parte organizada com livros destinados ao público adulto (abordando temas como educação, filosofia, psicologia, literatura, tecnologia entre muitos outros) e o espaço seja destinado ao uso da comunidade em geral, não há divulgação dessa possibilidade entre a comunidade e, mesmo se houvesse, acredita-se que a comunidade não faria uso do espaço dado os altos índices de analfabetismo e a cultura distanciada da palavra impressa. Além desses CEDIC's presentes nas escolas municipais, a carência do bairro em relação a centros culturais e bibliotecas é absoluta.

A consciência acerca da exposição ao crime organizado, o baixo nível de escolaridade dos pais e o trabalho duro e sacrificante ao qual a família é submetida, promovem, entre os alunos dos nonos anos em questão, um interesse grande em aprender e a refletir acerca das questões que circulam a desigualdade social. Muito embora os alunos tenham essa inclinação para a reflexão crítica acerca de sua situação social, falta ainda um refino no sentido de enriquecer as bases reflexivas dessas crianças para que elas possam compreender as questões sociopolíticas sobre as quais elas refletem de forma um pouco mais elaborada, retirando-as assim de um criticismo imaturo e imediato, que aponta problemas, mas não é capaz de compreender um processo maior por trás desses problemas.

Mesmo observando a inclinação reflexiva desses alunos ainda em estado inicial, é importante ressaltar que tal inclinação resulta num rendimento muito bom da sala diante das propostas de ensino aprendizagem executadas, na valorização do estudo e do conhecimento como possibilidade de uma vida melhor, no respeito e valorização em relação ao professor e numa postura crítica argumentativa inicial, porém, interessante.

\footnotetext{
${ }^{13}$ Nas quais estive presente como professora da educação infantil
} 
Em termos gerais, o nono ano no qual será aplicada a intervenção pedagógica referente ao presente estudo se constitui de alunos de baixo poder aquisitivo, que valorizam o estudo como uma oportunidade de vida melhor e têm grande interesse pelas questões sociopolíticas de seu tempo.

\subsection{Objetivo}

Conforme o já mencionado na Introdução, o presente estudo tem como marco inicial a hipótese de que a aproximação apropriada de gêneros narrativos pode proporcionar algo como um início de busca, uma inquietação que alerte o interlocutor do processo, os alunos no caso, para a importância da humanização.

Partindo da hipótese colocada, elaborou-se todo um estudo e uma adaptação do método LabLei para o ensino fundamental II da escola pública estadual, de modo a tratar da leitura do texto artístico literário em sala de aula, lançando bases para uma tentativa de implementação de um movimento de humanização no ambiente escolar.

Por uma perspectiva mais específica, o presente estudo busca alargar os horizontes humanísticos dos alunos envolvidos através da realização de uma intervenção pedagógica que, além de um mero exercício intelectual, promova a reflexão pelo contato com o texto não como objeto escolarizado, mas como objeto artístico, em torno de questões humanas em suas dimensões afetivas, intelectivas e volitivas, contribuindo para o autoconhecimento e o conhecimento do outro, condições fundamentais para a construção de uma sociedade mais respeitosa e humana, frente aos desafios impostos pelo discurso do ódio, pela segregação e pela polarização.

É importante o destaque para a compreensão do texto não como objeto escolarizado, mas como objeto artístico, como fonte de prazer estético, no qual, de acordo com Maria Zilda da Cunha:

[...] atenta-se para uma qualidade de sentimento total, uma espécie de simpatia intelectual, na sensação que dali emana há um sentimento que quer ser compreendido, um sentimento razoável. Um sentimento que reclama pela razão, irrecusável ao intelecto. (CUNHA, 2009. p. 28)

Assim, passemos ao estudo da metodologia mencionada, o LabLei e, na sequência, a uma tentativa de adaptação do método e elaboração da intervenção pedagógica a ser aplicada. 


\subsection{Metodologia}

Dante Gallian, idealizador do LabHum e do LabLei, desenvolveu uma metodologia através da qual se utiliza a literatura narrativa como meio para a vivência de uma experiência estético-afetiva que, por sua vez, busca implementar um resgate da humanização. Porém, a metodologia descrita por Gallian tem como público alvo alunos de nível superior, da Escola Paulista de Medicina da Universidade Federal de São Paulo - EPM-UNIFESP; e trabalhadores executivos do meio empresarial. O desafio está na adaptação dessa metodologia à realidade de crianças em idade escolar, mais especificamente, do $9^{\circ}$ ano de uma escola estadual pertencente à realidade de carestia supramencionada. Assim sendo, o presente estudo passará a observar cada uma das premissas metodológicas, colocadas por Gallian, e adaptá-las ao contexto dos alunos em questão.

A princípio, a metodologia do LabLei está organizada em cinco momentos:

- A reunião de apresentação.

- A leitura propriamente dita.

- A partilha das "Histórias de Leitura".

• A realização do "Itinerário de Discussão".

- A partilha das "Histórias de Convivência".

Cada um dos quais se passará a observar de forma um pouco mais detida a seguir.

\subsubsection{A Reunião de Apresentação}

A reunião de apresentação conta com a condução de um proponente/coordenador que irá apresentar a obra a ser lida, especificar algumas premissas sobre a qual se dará a leitura e marcar a data do próximo encontro. Em relação ao proponente/coordenador, é 
importante que ele mantenha uma relação emotiva intensa com a obra através da qual se tenciona produzir, em outros, a experiência estético-afetiva. De acordo com Gallian:

[...] a condição essencial para a proposição de um grupo de LabLei é o amor, a paixão e a conviç̧ão de seu proponente/coordenador. Ter experimentado o poder mobilizador da literatura no contexto da dinâmica do Laboratório e estar convicto dele é o primeiro passo para convencer, estimular e envolver a outros nessa aventura." (GALLIAN, 2017, p. 96).

É interessante observar que, para trazer a experiência estético-afetiva à tona em outros é preciso tê-la experimentado, tê-la vivenciado para conhecer os caminhos traçados entre a leitura de uma obra de arte e o sentimento estético dela derivado. Uma pessoa para quem a literatura nunca pôde despertar tal experiência, fatalmente, não poderá conduzir outros a esse sentimento. Mais do que conhecer tal experiência e confiar em sua força anímica, é preciso amá-la, é preciso que a fala desse proponente/coordenador seja investida de sentimento pela obra de arte narrativoliterária, que suas palavras se inflamem em um desejo intenso de dividir a experiência estética com outros, atribuindo à experiência estética toda a vibração e a grandiosidade digna do aspecto anímico da narrativa.

Essa relação afetiva do proponente/coordenador com a obra a ser explorada na ocasião do LabLei, por mais que se coloque como uma prerrogativa fundamental para o bom andamento do processo acaba por se configurar como uma dificuldade para o professor do Ensino Fundamental II. É obvio que a identificação subjetiva e emotiva do professor com a obra a ser trabalhada na escola potencializa os efeitos do trabalho docente, do ensinar, mas a organização burocrática curricular acaba por dificultar o estabelecimento de tal condição. Um ambiente escolar solidificado em torno de um currículo inflexível e do enrijecimento conteudístico oferece um considerável obstáculo à primeira premissa colocada por Gallian para o uso da narrativa literária como via para uma experiência estética. É difícil despertar sentimentos nos alunos através de trechos previamente selecionados, disponíveis em material didático, trechos arbitrariamente recortados, por uma perspectiva escolarizada, com o intuito de servir de suporte para a observação de determinado tópico gramatical ou determinado elemento textual. No caso de se implementar uma sessão visando o oferecimento de uma experiência estética, é importante que o professor tenha a oportunidade de trabalhar uma obra que, em primeiro lugar, seja capaz de produzir nele, professor, a grandiosidade anímica da experiência estético-afetiva. Forçar um professor de literatura a trabalhar com obras 
selecionadas por outrem impede que ele ofereça, a seus alunos, a grandiosidade da fruição pretendida.

Além de atrapalhar o trabalho do professor, a falta de espaço para o trabalho docente constitui uma grande contradição, pois documentos como o Currículo Paulista e o Currículo do Estado de São Paulo: Linguagens, Códigos e suas Tecnologias mencionam, por inúmeras vezes, a fruição.

O Currículo Paulista (2019) traz como uma de suas dez competências específicas de língua portuguesa para o Ensino Fundamental o seguinte:

\begin{abstract}
Envolver-se em práticas de leitura literária que possibilitem o desenvolvimento do senso estético para fruição, valorizando a literatura e outras manifestações artístico-culturais como formas de acesso às dimensões lúdicas, de imaginário e encantamento, reconhecendo o potencial transformador e humanizador da experiência com a literatura. (Currículo Paulista, 2019.)
\end{abstract}

Já o Currículo do Estado de São Paulo: Linguagens, Códigos e suas Tecnologias traz como uma de suas habilidades o ato de "Fruir esteticamente objetos culturais" ${ }^{14}$. Para isso, figura, em primeiro lugar, o espaço para a possibilidade de o professor poder escolher a obra literária que lhe promove tal experiência para que ele passe essa vivência, em sua intensidade, a seus alunos.

Além da necessidade de identificação e experimentação da energia estético-afetiva pelo proponente/coordenador, é importante que este coloque algumas instruções para o andamento da sessão. São elas:

- A postura do "leitor feliz".

- A instalação de uma atmosfera acolhedora que facilite manifestações simples e espontâneas por parte dos participantes.

- O tratamento preferencial de obras literárias em sua íntegra, não em fragmentos.

\footnotetext{
${ }^{14}$ Mais especificamente, o documento supramencionado, em relação ao ensino fundamental II, menciona, no item "Conteúdo de leitura, escrita e oralidade", a importância da fruição onze vezes, nas páginas 44, 48, 50, 56, 58, 60, 62, 64, 66, 72 e 74. Já a habilidade "Fruir esteticamente objetos culturais" é mencionada sete vezes, nas páginas $53,55,57,59,69,71,73$ e 75 .
} 
Gallian afirma que é necessário “[...] convidar o participante a assumir a postura do "leitor feliz"' (GALLIAN, 2017, p. 96, 97) mencionada por Gaston Bachelard na obra A poética do espaço. Trata-se de encarar a leitura de uma obra literária como algo prazeroso, como uma brincadeira ou como uma aventura em alguma outra dimensão, na qual se abandonam as amarras das regras e das convenções cotidianas. De acordo com Gallian:

\footnotetext{
Neste momento da experiência da dinâmica do Laboratório é preciso que o proponente/coordenador incentive o participante a partir desarmado e relaxado para a leitura do livro proposto, instruindo-o que o que se exigirá dele não será o que ele, eventualmente, esteve sempre a ser cobrado ao longo de sua vida escolar e universitária: uma visão técnica, "objetiva", histórica, que the permita identificar qual o "foco narrativo" do texto, quais as características mais marcantes e a qual fase ou período da história da literatura ele se insere (romantismo, realismo, regionalismo, etc). $\mathrm{O}$ proponente/coordenador deve, ao contrário, incentivar e preparar o participante para a experiência da "leitura feliz", informando-o claramente que o que se exigirá dele, num primeiro momento, é, simplesmente, o que ele sentiu, pensou e achou do livro proposto, sem se preocupar em formular teses, encontrar questões (ainda que estas, certamente, podem vir a emergir de forma espontânea, o que é absolutamente válido)" (GALLIAN, 2017, p. 97, 98. Grifo nosso).
}

Ao ser transposta para a realidade escolar, a postura do leitor feliz pode levar a duas situações diversas: a paralização dos alunos diante da dificuldade de compreensão do que seria essa leitura feliz por falta de referência e a resistência dos alunos, demasiadamente habituados às leituras enrijecidas pelos formalismos escolares. Porém, tais questões não significam a impossibilidade de realização da situação de aprendizagem, pois, assim que alguns alunos, ou mesmo o professor, iniciarem a manifestação de suas impressões e sentimentos, os paralisados ou resistentes tendem a compreender e a adquirir o processo como algo próprio, repetindo-o.

A única ressalva que faço em relação ao trabalho com a postura do leitor feliz em sala de aula seria a alteração do termo para leitor livre, pois a leitura literária não vai conduzir obrigatoriamente a sensações de alegria, é muito provável que o medo e a tristeza também apareçam. É óbvio que Bachelard, ao cunhar o termo, não estava mantendo seu referencial nas sensações despertadas pelo texto, mas na alegria de poder entrar em contato com suas sensações na leitura, de se refugiar onde os sentimentos, sejam eles de alegria ou tristeza, tenham seu espaço, porém, em se tratando de sala de aula, e considerando a possibilidade de leitura de um conto que verse sobre algum tema mais existencial, denso e reflexivo, é possível até mesmo ouvir alunos dizendo "Credo, 
professora, a senhora não disse que ia ser uma leitura feliz?”. De posse de tal observação, entende-se que o termo leitura livre ou leitor livre seja mais apropriado, uma vez que se almeja que os alunos, durante a leitura, compreendam-se livres de amarras ou convenções, livres para dar espaço aos seus sentimentos mais íntimos e confusos, sem juízos de valor ou julgamentos, distanciados do desconforto resultante da submissão a uma situação de apreciação formal coercitiva, própria ao ambiente escolar.

A postura do leitor feliz ou leitor livre deve ser acompanhada pela atitude da não cobrança de formalismos. Em momento algum se deve exigir uma exposição técnica sobre a obra lida, as manifestações devem ser simples e espontâneas, sem maiores elaborações ou reflexões. Gallian afirma que os participantes das sessões "apontam a agradável surpresa de encontrarem a possibilidade de se manifestarem com simplicidade, franqueza e sinceridade" (GALLIAN, 2017, p. 107). Um participante de um grupo desenvolvido em uma escola de negócios afirma:

[...] não precisamos 'elaborar' nossa fala para adaptá-la àquilo que supostamente o 'professor' ou coordenador quer ou gostaria de ouvir [...] você inclusive pode dizer, sem vergonha ou medo de represálias, de que não gostou ou não entendeu direito o livro. É claro que rápido a gente percebe que o problema em geral está conosco e não com o livro, mas o fato de poder dizer isso logo de início, nas Histórias de Leitura, é um excelente começo [...] (GALLIAN, 2017, p. 107)

É necessária a instalação de uma atmosfera acolhedora, receptiva e confortável, sem julgamentos ou juízos de valor, de forma que os participantes adotem a permissividade necessária para a real e sincera exposição de seus sentimentos e sua subjetividade. Na realidade, é essa a atmosfera esperada em qualquer ambiente de ensino, no entanto, é difícil encontrar uma sala de aula na qual semelhante ambiente se instale, na maioria das vezes a sala de aula se configura muito mais como um lugar hostil, no qual professores e alunos se encontram em conflito. Talvez seja esse o maior desafio ao tentar adaptar a realidade do Laboratório de Leitura à sala de aula: a instalação de uma atmosfera acolhedora que transmita, ao aluno, a segurança necessária para a exposição de emoções tão subjetivas. Na realidade, essa premissa deveria representar uma verdadeira revolução em cada uma das escolas brasileiras. Professores deveriam ser instruídos a abandonar qualquer postura autoritária de detentor supremo do saber e desenvolver uma sabedoria para a instalação de uma atmosfera acolhedora, que desarme seus alunos de suas posturas defensivas e os liberte da agressividade que tantos levam à sala de aula. É muito provável que isso leve tempo e que as estratégias para a 
instalação desse clima acolhedor variem de sala para sala, no entanto, é importante observar que a simples libertação das amarras linguísticas da norma culta ${ }^{15}$ já configura um passo importante na direção almejada. $O$ fato de se perceber livre para se manifestar na sua variedade linguística de maior conforto e o fato de ver seus colegas se manifestando de forma um pouco mais flexível e informal já configura um convite à manifestação mais confortável pelo aluno.

Por fim, há referência ao fato de que, seja qual for a obra a ser tratada, ela deve, preferencialmente, ser lida em sua totalidade, não em fragmentos, como costumam ser organizadas as atividades de leitura escolar. De acordo com Gallian:

\begin{abstract}
Quanto mais abrangente e profunda for a leitura da obra proposta, maior a amplitude da experiência estética que o participante vivenciará e assim, teoricamente, melhor será sua História de Leitura . Como vimos, na metodologia do LabLei, insiste-se para que cada participante leia a obra proposta completa antes do primeiro encontro. Isso não apenas para que ele possa ter uma impressão do todo, como também possa ter a oportunidade de reler a obra ao longo das semanas em que se desenvolverá o Itinerário de Discussão. (GALLIAN, 2017, p. 111 e 112)
\end{abstract}

Talvez, alguns alunos, especialmente os mais jovens ou os que tenham pouco contato com a cultura letrada, possam oferecer, a princípio, alguma resistência à leitura de um longo romance em sua totalidade. Por isso, seria interessante iniciar as sessões abordando algo um pouco mais breve, contos, por exemplo, e, o encantamento adquirido na experiência estética vivenciada através do conto, sem dúvida, constituir-seá no impulso inicial do aluno em direção a obras mais extensas. Vale a ressalva de que as obras devam ser "preferencialmente" lidas em sua totalidade, caso não haja a possibilidade de uma leitura completa, isso não é condição para a inviabilidade da aula, pelo contrário, o contato do aluno que não realizou a leitura completamente ou mesmo que não iniciou a leitura com as impressões dos outros colegas tende a despertar no primeiro um desejo maior em relação à retomada ou mesmo na iniciação da leitura. Segundo Gallian:

\footnotetext{
Ainda que, sem dúvida, a leitura completa da obra antes do início dos encontros seja ideal - e por isso altamente recomendada - ela nunca é imposta como obrigatória [...] uma atitude inflexível neste quesito, não apenas acabaria por limitar seriamente o número de participantes nos grupos como ainda inviabilizaria algo que, com o tempo, mostrou ser muito frequente na experiência: o de despertar o prazer de ler os clássicos e o de formar novos leitores. (GALLIAN, 2017, p. 113)
}

\footnotetext{
${ }^{15} \mathrm{O}$ que não significa o abandono dessa forma de ensino.
} 
Após essas recomendações, o proponente/coordenador apresenta a obra a ser lida e marca a data do próximo encontro.

Estando assim bem definidas as premissas iniciais sobre as quais se dão as orientações da reunião de apresentação e suas alterações no sentido de realizar uma adaptação entre a proposição de Gallian e a situação de sala de aula do ensino fundamental II, segue-se para a próxima etapa do LabLei: o momento da leitura.

\subsubsection{A Leitura Propriamente Dita}

De acordo com as recomendações do LabLei, a leitura deve se dar não coletivamente, junto ao grupo, mas de forma um pouco mais reservada, em casa ou em qualquer outro lugar onde os participantes do grupo tenham tempo livre e a concentração necessária para a realização da leitura.

A leitura reservada é de importância central para o andamento da atividade e para a instalação da experiência estético-afetiva. No contexto escolar, essa etapa poderia ser proposta como uma tarefa de casa, porém, já esperando pela possibilidade de que alguns alunos não leiam o texto proposto, principalmente, pela necessidade dos alunos de trabalharem para ajudar na renda familiar, seria interessante que, antes da exposição de suas impressões sobre a leitura, a professora realize uma leitura em voz alta, buscando incluir os alunos que não leram o texto em casa na atividade de socialização de seus sentimentos diante da obra.

\subsubsection{A Partilha das Histórias de Leitura}

O encontro de Histórias de Leitura compreende um momento no qual os participantes vão partilhar as suas reações diante da leitura do conto proposto. Basicamente, a palavra é atribuída a cada um dos participantes para que estes exponham o que mais lhe chamou a atenção ao longo do processo de leitura estabelecido. Nas palavras de Gallian, o objetivo principal do encontro de Histórias de Leitura é “[...] fomentar a expressão e compartilhamento da experiência estética pessoal, subjetiva de cada leitor participante [...] dar a oportunidade de que esses leitores contem, de maneira simples, franca, aberta as histórias de suas leituras" (GALLIAN, 2017. p. 100). 
As manifestações a serem colocadas durante o encontro de Histórias de Leitura devem versar sobre os afetos, os sentimentos, as lembranças, sobre grandezas mais subjetivas. Elaborações mais teóricas ou intelectualistas devem ser reservadas para o momento seguinte, o Itinerário de Discussão. Por isso, é importante que, para garantir o andamento do encontro, o proponente/coordenador tenha uma relação de perguntas disparadoras, que auxiliem os participantes a colocarem suas impressões subjetivas. Perguntas tais como "Como foi a leitura para você?", "Você gostou?", "Do que você mais gostou?", "O que foi mais difícil?" podem ajudar na elaboração das exposições realizadas pelos participantes. Obviamente que os participantes devem estar à vontade para expressarem o que lhes aprouver, no entanto, no caso de maiores dificuldades e "fugas" para colocações mais teóricas, as perguntas podem ser utilizadas. O intuito é observar o ser humano por um viés mais simples e espontâneo, menos científico e sistemático.

Além da partilha acerca da leitura do texto proposto em sua íntegra, podem aparecer também exposições relacionadas apenas a partes do texto proposto para leitura, caso o participante não tenha tido a oportunidade de ler o texto em sua completude. De acordo com Gallian:

\footnotetext{
Ainda que, sem dúvida, a leitura completa da obra antes dos encontros seja o ideal - e por isso altamente recomendada - ela nunca é imposta como obrigatória no LabLei [...] uma atitude inflexível nesse quesito, não apenas acabaria por limitar seriamente o número de participantes nos grupos [...] Não só Histórias de Leitura plenas são aceitas, mas também as que com o tempo foram ganhando o nome de História de meia Leitura, História de Leitura recém começada, ou até mesmo História de desejo de Leitura... (GALLIAN, 2017. p. 114)
}

Assim, observa-se que o momento de Histórias de Leitura deve ter como objetivo principal a partilha de experiências subjetivas de leitura em um ambiente simples e espontâneo, sem maiores preocupações teóricas sobre o texto lido. Embora o ideal seja a partilha de Histórias de Leitura com base na leitura em sua íntegra, também são aceitas exposições acerca de leituras que não abarquem o texto proposto em sua totalidade.

\subsubsection{A Realização do Itinerário de Discussão}

O Itinerário de Discussão trata de um momento um pouco mais teórico acerca do texto proposto, um momento no qual a dinâmica afetiva dá espaço à reflexão buscando resolver as questões colocadas durante as Histórias de Leitura. Nas palavras de Gallian: 
Reconhecendo que toda proposta efetivamente humanizadora deve partir da dimensão mais primária e essencial da vivência humana que é a dos afetos, o Laboratório privilegia, como ponto de partida, a experiência estética. Entretanto, reconhecendo também que a dinâmica do ser humano em seu caminho para se tornar cada vez mais humano - ou seja, de humanização não pode se limitar à dimensão afetiva, mas que, partindo do afeto, demanda necessariamente a participação da inteligência e da razão, a dinâmica do Laboratório permite e promove um segundo e indispensável nível de experiência, que é o da reflexão. (GALLIAN, 2017. p. 117, 118)

Observa-se que a dinâmica do LabLei elabora suas etapas de realização com base nas etapas do próprio processo definido aqui como processo de humanização. De modo semelhante à perejivânia vygotskyana, há, primeiramente, um momento de exploração do caráter anímico da narrativa em relação à sensibilização, na abordagem da dimensão afetiva e da experiência estética do leitor em contato com o texto; depois, um momento de reflexão, no qual, através da consideração um pouco mais racional acerca do texto, chega-se às respostas das perguntas apresentadas ao longo do momento de sensibilização.

Vale mencionar que o Itinerário de Discussão, invariavelmente, necessita de uma leveza e de uma delicadeza singulares, dado que ele deve ser colocado como um momento de apresentação e/ou de elaboração de mais uma leitura apenas, sem retirar, absolutamente, a legitimidade das leituras trazidas pelos alunos nas Histórias de Leitura. O Itinerário de Discussão, em hipótese alguma, busca colocar uma leitura oficial acabada, trata-se, somente, da exploração de mais uma perspectiva sobre a obra lida, exaltando sempre a riqueza de possibilidades e as profundezas abissais oferecidas pelo caráter vertical da leitura literária.

\subsubsection{A Partilha das Histórias de Convivência}

Fechando a sequência, chega o momento das Histórias de Convivência. Estas aparecem como um momento de avaliação acerca de todo o processo empreendido. Nas reuniões de Histórias de Convivência, há espaço para que cada um dos participantes partilhe aquilo que acharam do processo como um todo, quais foram as mudanças mais evidentes e marcantes para cada um. As Histórias de Convivência são a oportunidade de expor aquilo que, a partir daí, poderá orientar uma mudança de atitude, constituem a conclusão (ou o início, dado que a nova vida se origina ancorada sobre a mudança 
realizada) do processo empreendido com a atividade proposta no LabLei. Para Gallian, trata-se de uma oportunidade de:

[...] ampliar a reflexão, de concretizar e de possibilitar que toda a experiência estética e reflexiva influa na dimensão ética e prática da vida [...] possibilitam a culminação do processo reflexivo que se opera ao longo de todo o ciclo e que acaba por impactar no âmbito das atitudes e ações; ou seja, na dimensão da vontade. (GALLIAN, 2017. p. 135, 136)

As Histórias de Convivência trazem para as reuniões um elemento conclusivo, uma consideração final que busca relacionar as mudanças propostas através de uma síntese, um balanço, uma avaliação que encerra um ciclo e dá espaço para a realização de outros.

\subsubsection{Método LabLei sem o clássico, seria possível?}

Muito embora, o método LabLei trate de proporcionar uma experiência mais intensa de leitura através de obras clássicas, optou-se, no desenvolvimento do presente estudo, pela utilização de um conto da literatura marginal para oferecer aos alunos envolvidos na leitura, uma experiência estética capaz de transportá-los de uma concepção mais imediata a concepções mais universais em termos humanos. Para tanto, o conto selecionado foi Um novo brinquedo, de Rodrigo Ciríaco, um conto classificado como pertencente à literatura marginal, que se encontra publicado no livro Eu sou favela organizado por Paula Anacaona. Mas, antes de seguir elucidando as razões para a escolha de tal conto é importante pontuar o significado do termo literatura marginal e, para tanto, nada melhor do que recuperar a palavra de Reginaldo Ferreira da Silva, mais conhecido como Capão Pecado de Ferréz ${ }^{16}$, grande nome da literatura marginal, autor de Cidade de Deus e Manual Prático do Ódio.

Por marginal, Ferréz entende a busca de um lugar na série literária para aqueles que vêm da margem. E explica melhor: "Literatura marginal é aquela feita por marginais mesmo, até por cara que já roubou, aqueles que derivam de partes da sociedade que não têm espaço”. (FERRÉZ, 2005. apud HOLLANDA, 2018)

\footnotetext{
${ }^{16}$ FERRÉZ. Literatura marginal: talentos da escrita periférica. São Paulo: Agir, 2005.
} 
Em um primeiro momento, é importante verificar que o conto selecionado oferece uma oportunidade de identificação interessante, na medida em que ele recupera a voz dos excluídos, daqueles que não tem espaço social de manifestação. Os alunos pertencentes ao nono ano em questão percebem, desde muito cedo, as dificuldades representadas por suas condições diante da competitividade existente para a conquista de uma vaga na escola técnica da cidade, ou mesmo para a conquista de um emprego fixo por seus pais. É interessante oferecer a esses alunos realizações de pessoas que enfrentaram as mesmas dificuldades, ou contextos até mesmo mais excludentes. A literatura marginal, ao dar voz a pessoas marginalizadas pela organização do sistema socioeconômico vigente, afirma a possibilidade não apenas do exercício de manifestação através da literatura, da arte, mas também, por uma perspectiva um pouco mais generalista, defende a garantia de um espaço de inclusão da experiência de vida do indivíduo economicamente desfavorecido, morador da periferia, estudante da escola pública, em esferas maiores de consideração pública. Ao chegar às prateleiras das livrarias, aos meios digitais e até mesmo ao cinema, a literatura marginal, coloca a perspectiva do morador da periferia, suas dificuldades e conquistas, sua realidade, através de sua própria voz, sem intermediários, para o grande público. Saber-se digno de voz com tamanho alcance traz para o ambiente escolar algo de uma autoestima, da elaboração de novos horizontes, uma injeção de energia diante do fatalismo com o qual são tratadas essas crianças por muitas afirmações do senso comum. Ao contrário dos alunos da Escola Paulista de Medicina, dos trabalhadores executivos do meio empresarial e dos integrantes da classe média frequentadores dos encontros domiciliares do LabLei, que, de alguma forma, já se sentem inseridos na realidade social, os alunos de Jundiapeba precisam, imperativamente, de elementos que afirmem a possibilidade de inserção social, que alimentem o sonho da conquista de melhores condições de vida através de caminhos lícitos, mantendo-os longe do crime e da violência, de forma que a escola se coloque como uma instituição capaz de oferecer novas possibilidades de realização tanto sociais como pessoais.

Esse movimento que evidencia a possibilidade de manifestação através da literatura e garante espaço de inclusão em esferas maiores de consideração pública se dá, no conto em questão, através do retrato de uma ocasião bem específica na vida de Bryan, um menino de onze anos, estudante da escola pública, que se vê aflito com a mudança de horário na escola. Bryan, que sofreu complicações no momento de seu nascimento, acabou ficando mais baixo do que seu irmão gêmeo e recebeu, 
ironicamente, o apelido de Gigante. Agora, Bryan está preocupado por estudar pela manhã, junto com os alunos do ensino médio, que ficam "tirando onda" pelo seu tamanho. Como todo garoto que estuda pela manhã, Bryan fica atrasando a função "soneca" de seu celular, enrolando antes de ir para a escola, até que sua mãe liga e ele sai correndo, desesperado para não se atrasar, ele sabe que se perder o benefício do "Programa Bolsa Família" sua mãe iria endoidar. Até esse ponto da narrativa, há uma série de elementos que promovem a identificação dos alunos leitores com Bryan: o medo dos alunos maiores, a preguiça e a vontade de ficar mais tempo na cama, a preocupação ao saber que a família depende do auxílio governamental, porém, ainda não há o reconhecimento do fato de uma rotina tal como a de Bryan ser digna de representação literária, e mais, não há a menor consideração acerca de se refletir sobre essa realidade para se chegar a domínios mais universais, e será justamente sobre isso que o conto irá trabalhar.

A narrativa continua, Bryan corre para a escola com medo de perder a primeira aula e resolve pular um muro para cortar caminho. Ao cair sentado do outro lado do muro, Bryan encontra um brinquedo e fica encantado. A partir daí, Ciríaco inicia todo um trabalho de linguagem ao tratar do brinquedo de forma que o leitor crie a hipótese de que seu personagem, na realidade, tinha encontrado uma arma e que seria capaz de usar essa arma contra os "grandões" do ensino médio que tiravam sarro dele, ou contra ele próprio, retirando a própria vida. O jogo linguístico fica mais interessante na medida em que se percebe que há uma ideia preconcebida muito forte no leitor que ratifica o fato de que Bryan se entregaria à violência: o fato de se tratar de um garoto pobre. A cena final é dramática: após sofrer as brincadeiras dos alunos maiores, Bryan finge que passa mal para poder esperar o sinal da saída no portão. Ao soar do sinal, Bryan corre para casa para poder ficar algum tempo sozinho com o brinquedo. Ao chegar, ele se senta entre as camas, no quarto, retira o brinquedo da mochila, alisa o cano, mantém o dedo no gatilho e aproxima o cano do olho. Nesse momento, seu irmão chega e, com um grito, dá um susto em Bryan que, por acidente, aciona o gatilho do brinquedo. É apenas nesse momento que o leitor percebe que o brinquedo, na realidade, se trata de um caminhãozinho de bombeiro, que ainda tinha água em seu reservatório. Gigante fica com o rosto todo molhado, mas não briga com o irmão, dado o seu encantamento com a saga do brinquedo que acaba de achar: salvar vidas. Ao invés de brigarem, Gigante e o irmão vão para a rua brincarem juntos com o novo brinquedo. 
Primeiramente, é importante notar a astúcia do labor linguístico de Ciríaco nas escolhas lexicais que levam o leitor a pensar que o brinquedo em questão se trata de uma arma. Em um exame um pouco mais apurado, observa-se que muito embora haja mais motivos para acreditar que Bryan não se entregaria à violência, o leitor acaba escolhendo acreditar no pior.

\begin{tabular}{|c|c|}
\hline $\begin{array}{l}\text { Fez-me pensar que o "brinquedo" era uma } \\
\text { arma: }\end{array}$ & O Gigante... \\
\hline $\begin{array}{l}\text { o substantivo "cano" } \\
\text { o substantivo "gatilho", }\end{array}$ & $\begin{array}{l}\text { é preguiçoso, pois fica atrasando o soneca } \\
\text { do celular para não levantar e ir para a } \\
\text { escola. }\end{array}$ \\
\hline o verbo "sacar" & $\begin{array}{l}\text { é responsável, pois, mesmo atrasado e } \\
\text { com preguiça, foi correndo para a escola. } \\
\text { é esforçado, pois correu para não chegar } \\
\text { atrasado e conseguiu chegar antes do } \\
\text { início da primeira aula. } \\
\text { é obediente, pois obedeceu prontamente à } \\
\text { ordem (bronca) da mãe. } \\
\text { é sábio, pois, mesmo tendo um celular, } \\
\text { soube entender o valor de um } \\
\text { caminhãozinho de bombeiro. } \\
\text { é humilde, pois ficou muito feliz com um } \\
\text { brinquedo usado. } \\
\text { é sonhador, pois se encanta com a sina do } \\
\text { brinquedo: salvar vidas }\end{array}$ \\
\hline
\end{tabular}




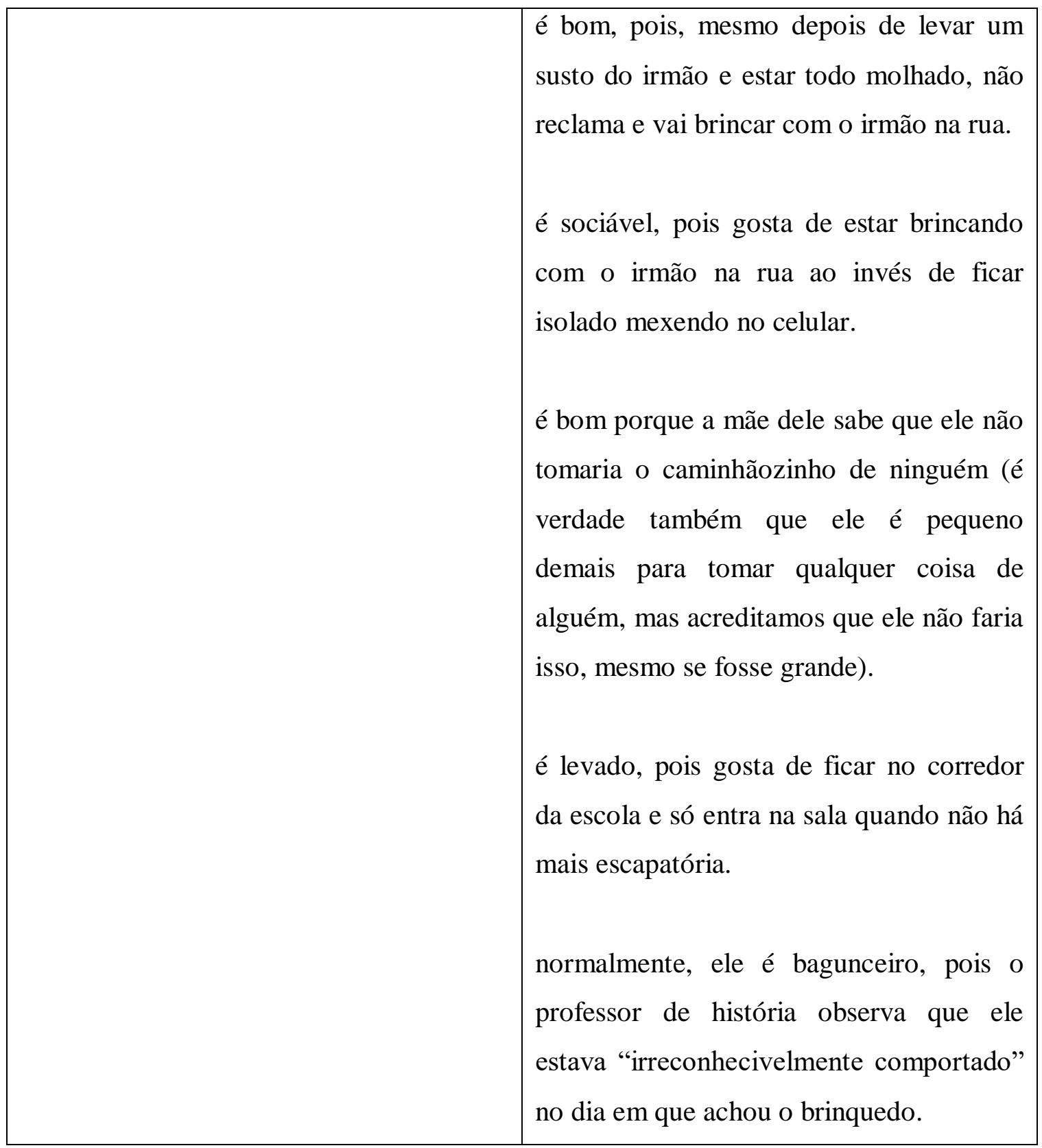

Ideias dos alunos acerca do personagem Gigante.

O quadro acima foi organizado no Itinerário de Discussão, junto dos alunos na aula. O quadro evidencia bem o fato de que, no conto há muito mais motivos para acreditar que Gigante não pegaria e levaria uma arma para a escola. Mas, mesmo constatando isso, grande parte dos alunos alegou pensar que o brinquedo era mesmo uma arma. Ao colocar a questão acerca dos motivos que levaram os alunos a tal constatação, muitos alegaram terem realizado tal julgamento por saberem que Gigante era uma criança pobre e negra, por pensar que gigante era um menino revoltado com sua situação, muito embora essas características não sejam colocadas pelo texto. 
Assim, observa-se que o conto traz uma oportunidade importante para a reflexão em torno dos processos através dos quais se dão alguns julgamentos, sobre as possibilidades de influência de ideias preconcebidas e a força de condução dessas ideias sobre a reflexão, na medida em que elas brotaram do próprio leitor, sem que o texto mencionasse, absolutamente, nada sobre elas.

Para além da reflexão em torno do astuto jogo linguístico elaborado por Ciríaco, observa-se também que o autor mantém o registro do conto no nível da fala dos alunos, o que volta a trabalhar no sentido de afirmar a realidade da periferia como digna de representação artística legítima. Essa identificação inicial, tanto em níveis de linguagem como em relação à temática abordada é importante por levar o aluno a considerar a literatura como algo mais próximo, possível de ser experimentado e compreendido, ao contrário dos academicismos que tendem a afirmar certo caráter elitista na apreciação artística literária.

Ao focalizar a vida da periferia pela perspectiva artística, as realizações narradas tomam uma dimensão maior, o eixo vertical de representação de certos símbolos toma proporções universais em sentidos variados. O próprio caminhãozinho de bombeiro aparece aos olhos do leitor, a princípio, com certo questionamento: um singelo caminhãozinho de plástico, com escada, reservatório e mangueira, o que poderia representar esse brinquedo tão simples diante do vasto horizonte oferecido pelos aparelhos eletrônicos? É interessante observar que, muito embora, Gigante possua um aparelho celular, essa realidade não o atrai como o caminhãozinho o faz. Os colegas da escola chamam Gigante para ver novos aplicativos, mas ele não vai. Mesmo gostando de ficar nos corredores, ele prefere ficar na sala, junto de sua mochila que porta o brinquedo. O fascínio de Gigante e seu irmão com o brinquedo traz para a composição do conto o sentimento de heroísmo que transforma o brinquedo de algo singelo em algo grandioso:

Só parou quando viu o quanto da hora era o brinquedo. Tinha sirene, buzina e até uma escada Magirus, igualzinho ao caminhão de verdade que eles viram quando eram bem pequenos e, na sintonia que só os gêmeos possuem ficaram ambos hipnotizados com o caminhão e sua potência, o barulho que fazia ao trafegar e a sua saga: salvar pessoas. (CIRÍACO In: ANACAONA, 2015. p. 25)

Para além da grandiosidade da saga de salvar vidas, o caminhãozinho ainda evoca a magia das experiências marcantes da infância. De acordo com o trecho reproduzido 
acima, Gigante e o irmão já haviam tido a experiência de ver um caminhão de bombeiros de verdade quando eram bem pequenos. As experiências da infância, quando evocadas, aparecem sempre dotadas de uma força impressionante, de uma magia que apenas os olhos de uma criança podem enxergar e compreender. $\mathrm{O}$ caminhãozinho simboliza não apenas o heroísmo em sua saga de salvar vidas, mas também tem seu heroísmo potencializado pela magia advinda do olhar de uma criança, cujos sonhos, ainda não contaminados pelas frustrações comuns à experiência da vida, conservam um idealismo puro e grandioso.

O caminhãozinho conserva em si, simultaneamente, a grandiosidade do heroísmo sob a perspectiva do olhar da criança e a singeleza de um brinquedo de plástico diante de tantos outros brinquedos, dotados de uma interatividade que somente a tecnologia pode conceder. Atualmente, jogos de smartphones ou de videogames parecem sobressair de maneira inquestionável diante de um simples caminhãozinho, porém, não ao entendimento de Gigante que compreende a grandiosidade, paradoxalmente, envolvida nas estruturas plásticas do caminhãozinho. Gigante não tem nas mãos apenas um brinquedo de plástico, ele não apenas sabe, mas age de forma a evidenciar o reconhecimento do valor que há no brinquedo. Gigante, mesmo sendo menor que um anão de jardim, se mostra grandioso ao constatar, sabiamente, a simbólica do heroísmo e da magia plasmada no singelo brinquedo. Gigante tem o poder de perceber a grandiosidade presente em coisas pequenas, o que o liberta das constatações fatais do senso comum e abrem a ele um fascinante mundo onde o pouco que ele possui representa muito mais do que olhos viciados na realidade consumista tecnocrata do senso comum podem ver.

Mais do que isso, o caminhãozinho ainda representa o encontro com o outro. Em uma contemporaneidade na qual o ser humano se refugia na realidade privada e as tecnologias de comunicação constroem relações intermediadas pelos aparelhos eletrônicos, o caminhãozinho representa também o encontro dos irmãos que vão juntos brincar na rua, realizando um movimento na contramão do isolamento comum à atividade lúdica eletrônica. O caminhãozinho representa o estar junto, o brincar junto, o calor das relações em presença real, no mesmo tempo e no mesmo espaço, que se dá na rua, no espaço público.

Após esse breve exame do conto Um novo brinquedo, conclui-se que, muito embora o conto ainda não tenha sido agraciado com o qualificativo de clássico, ele se apresenta como uma interessante escolha para o trabalho com a humanização diante da 
sala de nono ano em exame, já que ele afirma a possibilidade da vida na periferia e da linguagem dos próprios alunos como objeto digno de representação literária artística; coloca um interessante trabalho formal no labor linguístico do autor ao representar o brinquedo, o que dá margem para o aparecimento de ideias preconcebidas no momento de julgamento do personagem; trabalha com o símbolo do caminhãozinho de bombeiros explorando questões universais tais como o heroísmo, a magia das experiências vividas na infância, a sabedoria de enxergar a grandiosidade nas coisas pequenas e o encontro com o outro em uma sociedade na qual se tem produzido, cada vez mais, isolamento.

\subsection{Proposta de Intervenção Pedagógica}

De posse da metodologia elucidada por Gallian e com o cuidado de colocar em prática uma adaptação dessas premissas para o contexto da sala de aula, como o estipulado anteriormente, o presente estudo propõe uma atividade de leitura ao modelo LabLei, que se daria em um total de oito aulas, organizadas em quatro etapas a serem realizadas entre os dias 05 e 12 de novembro de 2018.

\subsection{1. $1^{\text {a }}$ Etapa: Apresentação da Atividade}

O momento de apresentação da intervenção pedagógica elaborada consiste na proposição, pela professora, de uma atividade de leitura. Tal leitura não deve ser entendida como algo escolarizado, com objetivos instrutivos, ela deve ser apresentada aos alunos como a oportunidade de imersão em uma nova experiência, sem a fixação racional na observação deste ou daquele conceito estudado. Os alunos devem compreender a proposta de leitura por uma perspectiva muito mais lúdica e prazerosa, como a visitação a uma nova realidade na qual a observação dos personagens e o desenrolar dos fatos dependam do seu entendimento, de uma construção advinda de suas emoções e sensações, de suas recordações, suas experiências mais marcantes. O cerne da proposição está não na objetividade ou na formalidade do caráter instrutivo, mas na liberdade de construção de sentidos em torno das impressões despertadas, no caráter fruitivo do contato do aluno com a obra literária e na possibilidade de tradução da experiência estética diante de um objeto artístico. A instalação de tal atmosfera é o que se denomina como leitura livre, uma leitura distanciada do medo ou do desconforto 
resultante da submissão a uma situação de apreciação formal coercitiva tão comum no ambiente escolar.

Logo após a experimentação da leitura livre, os alunos serão instruídos a produzirem algum tipo de manifestação gráfica possível de ser realizada em papel: um texto, um desenho, uma colagem etc. que traduza em significação a experiência vivida. Essa manifestação gráfica será fixada em folhas de caderno e deverá ser reservada para a elaboração do Diário de Leitura. Este contará com quatro partes: a Leitura Livre, a partilha das Histórias de Leitura, o Itinerário de Discussão e as Histórias de Convivência. Após a elaboração das mencionadas quatro partes, os alunos serão orientados a confeccionar uma capa para o Diário, que deve sintetizar em uma imagem aquilo que, para eles, foi mais significativo ao longo de todo o processo.

É importante que, desde o princípio da atividade, esteja claro para os alunos envolvidos que em nenhum momento haverá a avaliação formal dos registros feitos no diário, cada um deles terá liberdade para manifestar suas impressões e sentimentos, suas emoções e lembranças da maneira como melhor lhe aprouver. Deve-se pontuar, de forma incisiva, que esse não é o momento de avaliações referentes ao uso da norma culta, pelo contrário, haverá espaço para a expressão através da variação de maior conforto, aceitando-se gírias e até mesmo outras linguagens tais como o poema, o rap, o desenho, o grafite, a montagem a colagem etc. É grandiosa a importância do aceite e do incentivo à exploração de novas linguagens, tanto para o enriquecimento das formas de expressão dos alunos implicados como para a inclusão de alunos especiais ${ }^{17}$. A real avaliação diante dos Diários deve tomar como objeto de observação a capacidade e o nível de reflexão, identificação e expressão desenvolvidas ao longo da experiência vivenciada. Trata-se de observar a tradução de um percurso no qual o aluno tem a possibilidade de entrar em contato consigo mesmo através da reflexão em torno da própria subjetividade, ressignificando fatos vividos através do contato com o texto como objeto artístico.

Também é importante deixar claro, desde o início da intervenção pedagógica, que existe a possibilidade de a leitura, a princípio, não proporcionar nenhuma sensação tão intensa. Vivemos em um cenário tão massificado que não há o costume de observar, com a atenção e a profundidade necessárias, as minúcias de nossas profundezas mais

\footnotetext{
${ }^{17}$ É importante que haja maiores estudos acerca das possibilidades do trato com a linguagem através do LabLei diante de alunos portadores de necessidades especiais, sobretudo aqueles com dificuldades de ordem intelectual.
} 
subjetivas. Assim, é importante que o aluno saiba que o registro de sua experiência de leitura pode vir a ser algo extremamente sutil, que exija maior concentração na busca de qualquer pequena ocorrência, qualquer pensamento que, normalmente, seria negligenciado. Mesmo no caso de o aluno alegar a si mesmo, durante a leitura, que não está vivenciando absolutamente nada, o "nada" em questão deve ser observado na tentativa de ser traduzido em palavras e expresso. O tal "nada" pode vir à tona através de alguma dúvida, da explicitação de algum trecho do conto que não tenha ficado claro ou, até mesmo, de sugestões acerca do andamento do enredo diante das quais o aluno expresse alguma emoção que o conduza a uma busca inicial pela elaboração da própria subjetividade.

Logo após todas essas explicações acerca da experiência de leitura a ser vivenciada, a professora entrega o conto a ser lido e avisa que haverá, na aula seguinte, uma roda de conversa na qual os alunos irão partilhar dos registros elaborados nesse primeiro momento.

Como o mencionado anteriormente, o conto selecionado para a realização da sequência foi Um novo brinquedo de Rodrigo Ciríaco, disponível no item Anexos do presente estudo.

\subsection{2. $2^{\mathrm{a}}$ Etapa: Histórias de Leitura}

A aula a seguir apresenta-se como ocasião para a partilha das experiências vivenciadas com a leitura livre. Inicialmente, a aula conta com dois momentos distintos: no primeiro momento os alunos serão organizados em grupos menores para um debate inicial acerca das experiências traduzidas; no segundo, haverá uma grande roda de conversa, na qual os alunos tomarão a palavra diante dos colegas no sentido de expor as suas impressões e de considerarem a exposição do outro.

O primeiro momento, o encontro dos alunos em grupos menores, é uma tentativa de proporcionar mais uma chance àqueles que, por algum motivo, não realizaram a tarefa. É importante que esse aluno seja integrado ao momento seguinte, que tenha alguma elaboração a expor na roda de conversa maior mesmo que seja apenas de forma falada, mesmo que seja uma colocação em relação à experiência do colega. Além dessa nova oportunidade oferecida aos alunos que não tenham feito a tarefa, o momento da organização em grupos menores também é importante por realizar um encontro dos 
alunos entre aqueles colegas com quem eles mantêm maior contato e afinidade, de forma que a exposição das ideias registradas no Diário sejam, primeiramente, expostas em um ambiente mais confortável. Caso o aluno sinta que ele não deseja expor suas ideias no momento da roda de conversa entre todos os alunos da sala, ele pode colocar uma observação ou uma reflexão sobre o registro de algum colega, com o qual ele manteve contato anterior.

Concluída essa etapa inicial, com os grupos menores, passa-se à organização da roda de conversa maior. Nesse momento, cabe à professora o papel de mediadora, organizando a atividade e orientando a troca dos turnos de fala entre os alunos envolvidos. É possível que os alunos apresentem alguma resistência em relação à exposição proposta, para isso, é importante que a professora traga consigo uma lista de perguntas que auxiliem os alunos em dificuldades no momento de sua exposição. Perguntas como "Você gostou do conto lido?", "Que parte você gostou mais?", "Por quê?", “O que mais chamou sua atenção no conto ou em determinada parte?", "O que você sentiu ou pensou lendo o conto ou determinada parte?" podem ser valiosas no momento de contornar uma eventual situação de desconforto ou para incentivar o uso da palavra por algum aluno.

Enquanto os alunos vão fazendo uso da palavra no desenrolar da roda de conversa, é importante que a professora vá tomando nota dos temas mais frequentemente mencionados, das dúvidas, de qualquer elemento que julgar importante ser retomado no momento seguinte, o Itinerário de Discussão.

A ocasião das Histórias de Leitura é uma oportunidade de compartilhamento da experiência de leitura vivenciada de forma simples e espontânea, da exposição dos alunos acerca daquilo que eles encontraram de mais humano dentro de si mesmos e da troca desse poderoso achado, o que deve acontecer sem interferências por parte da professora, esta se coloca diante da atividade apenas como mediadora dos turnos de fala.

É importante ainda a ressalva acerca da possibilidade de que os alunos venham para o encontro de Histórias de Leitura sem terem realizado a leitura do conto. Caso se observe tal ocorrência, a professora pode realizar uma leitura do conto em sala de aula antes da organização dos alunos nos grupos menores. Nesses grupos, os alunos teriam mais um momento para realizar um debate sobre o conto e mais uma oportunidade para efetivar o registro de suas impressões de leitura nos Diários. Mesmo que isso aconteça e haja a necessidade de uma leitura em sala de aula, observa-se que esse procedimento 
não é o ideal dado que, assim os alunos perdem a oportunidade de se observarem em uma experiência retirada, entregue às próprias sensações e reflexões, distanciada de uma leitura que pode ser conduzida de alguma forma pela realização de terceiros.

\subsection{3. $3^{\text {a }}$ Etapa: Itinerário de Discussão}

Nessa terceira etapa, o objetivo maior é incentivar a reflexão e debate acerca de alguns dos temas mais frequentemente mencionados ao longo das Histórias de Leitura.

De posse de suas anotações realizadas ao longo do último encontro, a professora deve, primeiramente, de acordo com a elaboração de Gallian, estabelecer pontos de partida e de chegada para cada um dos temas a serem explorados ao longo do Itinerário de Discussão, sem, obviamente, interferir na espontaneidade dos alunos. A organização da condução do Itinerário e o estabelecimento de pontos de partida e de chegada são importantes no sentido de evitar que o momento redunde em discussões polarizadas, na demasiada digressão ou mesmo dispersão em relação ao assunto proposto. É recomendável que a condução e seus pontos de partida e de chegada também estejam registrados e ao alcance da professora no momento da realização da atividade. Assim como as Histórias de Leitura contavam com um conjunto de perguntas disparadoras, o Itinerário também deve contar com a organização da condução, uma série de perguntas disparadoras e, até mesmo, com uma paráfrase do conto em questão. Mesmo sabendo que, no momento da reflexão, o protagonismo é do aluno, é importante ter um planejamento ao qual recorrer caso as falas dos alunos se esgotem. É também importante deixar claro que esse planejamento não visa a condução inflexível da atividade, ele é apenas uma elaboração de alternativas, caso o debate conflua para os domínios da polarização ou da digressão exacerbada.

Com esse planejamento de condução entre os pontos de chegada e de partida, a professora deve organizar uma nova roda de conversa, sugerir os temas, retomar algumas colocações feitas ao longo das Histórias de Leitura e propor a reflexão.

A professora pode dispender de um número maior de aulas para propor as reflexões do Itinerário ou ser mais concisa. Não há problema caso não seja possível esgotar todos os temas elaborados para a reflexão, um único tema, abordado em sua profundidade, é suficiente para despertar nos alunos o movimento de busca no sentido 
de reproduzir a experiência estética e o tratamento dos sentimentos através de uma reflexão um pouco mais detida.

O uso dos Diários de Leitura para o registro de qualquer que seja a reflexão que o aluno observe como algo interessante ao longo do Itinerário de Discussão é extremamente recomendável e deve ser estimulado pela professora.

Ao final da aula abordando o Itinerário de Discussão, a professora orientaria seus alunos a realizarem uma avaliação da sequência empreendida até então e registrassem em seus Diários aquilo que, para eles, foi mais marcante, mais forte e que seria capaz de levá-los a algum tipo de mudança interior.

\subsection{4. $4^{\mathrm{a}}$ Etapa: Histórias de Convivência}

O momento das Histórias de Convivência busca colocar um desfecho à sequência trabalhada, de forma que seja realizado, por parte dos alunos, um balanço acerca do que aprenderam, do que mais os marcaram, do que mais trouxe inquietação ao longo da experiência de leitura apresentada.

$\mathrm{Na}$ ocasião, mais uma vez os alunos são organizados em uma roda de conversa e fariam uso da palavra colocando aquilo que, para cada um deles, foi mais significativo ao longo da intervenção experimentada. Todos eles poderiam fazer uso de suas anotações nos Diários para expressarem melhor seus pontos de vista.

Com a conclusão da atividade após esse momento avaliativo, pode-se propor um novo ciclo da atividade, apresentando uma nova obra a ser lida e repetindo os procedimentos da reunião de apresentação. Esta seria mais rápida, pois os alunos já estariam familiarizados com a Leitura Livre.

\subsubsection{Cronograma de realização}

A seguir, o cronograma com a distribuição das etapas elaboradas para a intervenção didática: 


\begin{tabular}{|c|c|c|c|c|}
\hline & $\begin{array}{c}05 \mathrm{de} \\
\text { Novembro }\end{array}$ & $\begin{array}{c}06 \mathrm{de} \\
\text { Novembro }\end{array}$ & $\begin{array}{c}08 \mathrm{de} \\
\text { Novembro }\end{array}$ & $\begin{array}{c}12 \mathrm{de} \\
\text { Novembro }\end{array}$ \\
\hline $\begin{array}{c}\text { Apresentação da } \\
\text { Atividade }\end{array}$ & $\begin{array}{l}\text { Duas aulas } \\
\quad \text { (cem } \\
\text { minutos) }\end{array}$ & & & \\
\hline $\begin{array}{c}\text { "Histórias de } \\
\text { Leitura" }\end{array}$ & & $\begin{array}{l}\text { Duas aulas } \\
\text { (cem } \\
\text { minutos) }\end{array}$ & & \\
\hline $\begin{array}{l}\text { "Itinerário de } \\
\text { Discussão" }\end{array}$ & & & $\begin{array}{c}\text { Duas aulas } \\
\text { (cem } \\
\text { minutos) }\end{array}$ & \\
\hline $\begin{array}{l}\text { "Histórias de } \\
\text { Convivência", }\end{array}$ & & & & $\begin{array}{l}\text { Duas aulas } \\
\quad \text { (cem } \\
\text { minutos) }\end{array}$ \\
\hline
\end{tabular}

Cronograma de aplicação das etapas da intervenção pedagógica 


\section{Descrição das Etapas de Intervenção Pedagógica Desenvolvidas e Análise dos Resultados}

Quanto à descrição da intervenção pedagógica, há de se mencionar que esta será organizada através das etapas previamente adaptadas. Logo após a descrição da aplicação, virá a análise que toma como objeto de observação os Diários de Leitura produzidos pelos alunos. À semelhança da descrição da intervenção, a análise também se apresentará organizada através das etapas adaptadas, dado que cada uma das etapas orientam a escrita de um item do Diário de Leitura.

\subsection{1. ${ }^{a}$ Etapa: Apresentação da Atividade}

Conforme o estipulado na Proposta de Intervenção Pedagógica, foi apresentada, aos alunos, uma atividade de leitura na qual o foco estaria na observação dos seus sentimentos e emoções diante do exercício da Leitura Livre.

Essa leitura deve orientar uma produção escrita, o Diário de Leitura, no desenvolvimento do qual o aluno recebeu total liberdade para o uso das mais variadas linguagens em sua expressão.

Os alunos responderam à apresentação da atividade de forma bastante positiva, afirmaram grande entusiasmo tanto por se tratar de algo diferente para eles como por se sentirem desafiados. Houve também manifestações positivas em relação à possibilidade de tratar dos próprios sentimentos, tanto pelo desejo de compartilhar o que se sente como pela expectativa em ouvir os outros.

Diante do entusiasmo dos alunos em relação à atividade apresentada, a professora decidiu por provocar certo mistério em relação ao conto a ser lido. A professora se dirigiu aos alunos com as cópias do conto nas mãos e disse apenas que ela faria a entrega, mas nenhum aluno deveria olhar para o conto, pois se tratava de um "conto secreto", que se converteria em uma surpresa apenas quando cada um dos alunos chegassem em casa, arrumasse um lugar tranquilo e, de preferência, onde estivessem sozinhos para ler e fazer as anotações no Diário, apenas após o registro das impressões de leitura é que eles poderiam compartilhar o conto com outros. Muitos alunos demostraram gostar da brincadeira do "conto secreto", eles recebiam o conto, o dobravam e colocavam dentro do caderno com os olhos fechados. 
Já nesse momento, muitos alunos afirmaram estarem sentindo curiosidade e até mesmo uma pequena ansiedade pelo desejo de saber do que se trataria o "conto secreto".

\section{2. $2^{\text {a }}$ Etapa: Histórias de Leitura}

A aula seguinte tratou do encontro de partilha, no qual cada um dos alunos colocaria, diante dos colegas, algo em relação à sua experiência de Leitura Livre. Em termos gerais, a aula se desenrolou na seguinte proporção cronológica: havia um total de cem minutos dos quais os primeiros vinte minutos foram utilizados para colocar a sala em ordem, em realizar a chamada e em expor algumas informações acerca do andamento da aula. Outros vinte minutos foram utilizados na leitura em voz alta do conto, na partilha em grupos menores e na organização da roda de conversa.

Mesmo com a manifestação inicial, por parte dos alunos, de certo entusiasmo e curiosidade, oito alunos não leram o conto e não realizaram os registros no Diário. Assim, a professora achou necessário realizar uma leitura em voz alta do conto em questão diante da sala, conforme o previsto no subitem Histórias de Leitura da Proposta de Intervenção Pedagógica.

Após a leitura, a professora separou os alunos em oito grupos, de forma que cada um dos alunos, que não haviam feito a tarefa, tivesse a oportunidade, com base na leitura realizada pela professora e no contato com os colegas do grupo, de realizar as anotações em seus Diários de Leitura.

Após esse momento em grupo, todos os alunos da sala estavam com seus Diários escritos e prontos para a roda de conversa, na qual haveria a partilha das sensações vividas na leitura com todos os presentes.

A professora orientou a organização da sala, as mesas foram afastadas e um círculo foi formado com as cadeiras. Cada um dos alunos e a professora tomou seu lugar no círculo e, com seus Diários em mãos, tiveram início as Histórias de Leitura. Nesse momento, a professora contava ainda com um total de cinquenta minutos de aula.

Cada um dos alunos na roda teve a oportunidade de fazer uso da palavra de forma que as falas se iniciaram com o aluno que estava à direita da professora e se seguiu até o aluno à esquerda da professora. 
Foi muito importante a ação da professora na organização dos turnos de fala, pois, assim que um aluno colocava algum sentimento, os outros respondiam com grande alegria por terem sentido o mesmo e o grande entusiasmo diante de algumas manifestações acabou por atrapalhar um pouco a ordem da atividade. Assim, a professora orientou os seus trinta e sete alunos presentes, sentados em roda, que se contivessem, levantassem a mão e que aguardassem a professora lhes passar a palavra, de forma que o aluno que inicialmente estivesse colocando seus sentimentos não fosse interrompido. Surgiu então a seguinte regra para a realização da roda de partilha: deixe o colega terminar de falar, caso você queira fazer algum comentário sobre a fala do colega, aguarde com a mão levantada até que a professora lhe passe a palavra.

Depois da colocação dessa regra, trinta e seis dos trinta e sete alunos presentes conseguiram se manifestar sobre a sua experiência de Leitura Livre, apenas um ficou para se colocar na próxima aula, pois o sinal do intervalo já havia soado.

$\mathrm{Na}$ aula seguinte, no dia seis de novembro, a roda foi organizada novamente, a professora realizou uma retomada da atividade desenvolvida na aula anterior, relembrando algumas falas e passou a palavra para o aluno que não havia se manifestado. Ele se colocou e, assim como na aula anterior, os alunos teceram alguns comentários acerca de suas colocações.

Ao longo de todo o período destinado à partilha das experiências de leitura, a professora realizou uma série de anotações não apenas para retomar a atividade na aula seguinte, mas também para colher elementos a serem utilizados na próxima etapa da sequência, o Itinerário de Discussão.

Os dois alunos que faltaram na aula anterior estavam presentes nessa aula e não tinham realizado a leitura do conto. Embora não houvessem lido, eles estavam com a cópia entregue na apresentação da atividade, assim, a professora orientou-os para que realizassem uma leitura silenciosa do texto ali mesmo, em sala de aula e observassem o que sentem ao longo da leitura, para poderem participar da próxima atividade. Com a inclusão dos faltosos no processo, a aula seguiu para o Itinerário de Discussão.

Vale mencionar que todo o processo referente às Histórias de Leitura foi realizado com grande entusiasmo por parte dos alunos, nenhum dos alunos presentes ofereceu resistência ao fato de se manifestar diante do outro, muito pelo contrário, o único aluno que não pôde falar, por ter se esgotado o tempo da aula, e mostrou muito frustrado por querer falar e não poder, por ter de esperar a aula seguinte para se colocar. 
Em relação às manifestações dos alunos, algumas delas tornaram-se dignas de nota: o terceiro aluno a fazer uso da palavra estava relatando que ele havia se identificado muito com o protagonista do conto pelo fato do aluno também ter um irmão gêmeo e também ter sido o segundo a nascer. Por ter demorado a nascer, o aluno, assim como o personagem, passou por maiores complicações e teve de ficar algum tempo na UTI neonatal. O aluno relatou que, um de seus parentes, ao indagar o médico acerca das possibilidades de sobrevivência do bebê, recebeu a seguinte resposta: "Ah! Isso aí é igual passarinho, na mesma hora que está vivo, está morto". A sala recebeu a partilha com risos. Após os risos a professora interrompeu a sequência de partilhas e perguntou aos alunos quem ali tinha irmão mais novo e viu a mãe passar pela gravidez. Catorze alunos levantaram a mão. A professora, então, pediu para que esses alunos falassem sobre o que eles tinham achado da gravidez que acompanharam. Três alunos se colocaram dizendo que, mesmo sendo algo bom, por gerar vida, a gravidez também era algo muito difícil. Esses três alunos que se pronunciaram viram a mãe passar por uma gravidez difícil e um deles viu a mãe perder o bebê. Eles narraram com detalhes os sofrimentos aos quais suas mães foram sujeitas. A professora disse para que cada um dos alunos presentes imaginasse a sua mãe ou até mesmo a si mesmo passando por uma situação semelhante, ter o seu bebê em perigo de vida e ouvir do médico o que o parente do colega havia ouvido. A sala ficou em silêncio. A professora orientou a sala a tomar cuidado com o riso, pois o riso é extremamente revelador, o riso mostra o quanto podemos ser cruéis e o quanto nos falta em empatia. A professora anotou a palavra "empatia" na lousa e voltou para o seu lugar na roda. Um aluno perguntou o que era empatia. A professora respondeu apenas que era aquilo que eles estavam sentindo naquele momento e que, depois, explicaria melhor o significado da palavra anotada na lousa. O silêncio se perpetuou até que, um aluno levantou a mão e pediu para que todos os que tivessem dado risada que pedissem desculpas ao colega que havia partilhado a lembrança de seu nascimento. Todos pediram perdão e, orientados pela professora, agradeceram a oportunidade de aprender com a partilha feita. Outro aluno pediu para dar um abraço no colega. A professora consentiu. Houve um abraço e uma salva de palmas.

Muito embora as intervenções maiores sejam objeto do Itinerário de Discussão, a intervenção realizada foi de extrema importância não apenas para chamar a atenção dos alunos em relação a uma conduta não desejável, mas também para garantir o andamento respeitoso da atividade. A partir daí ficou evidente a instalação de uma atmosfera de 
respeito, receptividade e compreensão entre os alunos, resultante do reconhecimento do outro como um ser humano, semelhante a cada um deles. Assim, alunos que já haviam partilhado passaram a se sentir mais seguros e pediam a palavra novamente para colocarem mais sentimentos e lembranças que tiveram em relação à leitura.

A atmosfera de respeito instalada abriu caminho para mais uma ocorrência interessante. Uma das alunas estava oferecendo muita resistência não apenas para participar da atividade em questão, mas ao longo de todo o ano letivo, chamaremos essa aluna pelo pseudônimo de Bárbara. Bem no início do ano, Bárbara se mostrava ser uma boa aluna, tinha muitas amigas e tudo ia bem, mas depois de algumas semanas de aula Bárbara havia se afastado das colegas, parou de fazer as lições, começou a faltar muito e apresentava uma conduta estranha, sendo capaz de destruir uma carteira e uma cortina da sala de aula. Ao ser estimulada a se colocar diante da sala pela professora, Bárbara começou a chorar e não dizia nada. Os colegas, então, começaram a estimulála dizendo que eles gostariam de ouvi-la e que ninguém ali iria julgá-la. A aluna continuou calada e chorando quando, outra aluna, nomeada aqui como Antônia, também começou a chorar e pediu a palavra. Antônia disse que estava muito triste por ver Bárbara naquela situação, sem levar a sério a escola e quebrando as coisas na sala, disse também que se sentia muito culpada porque sabia que Bárbara estava fazendo tudo aquilo por ter ficado isolada. Resumidamente, as duas haviam brigado no início do ano e Antônia havia convencido todas as outras meninas da sala a isolarem Bárbara, como resultado do isolamento, Bárbara passou a ter uma conduta inapropriada. A professora se dirigiu à Bárbara e perguntou se tudo aquilo era verdade. Bárbara respondeu que sim. Antônia pediu novamente a palavra e disse que gostaria de pedir perdão para Bárbara. Bárbara aceitou o pedido de perdão e deu um abraço, entre muitas lágrimas, em Antônia. Houve nova salva de palmas e alguns alunos afirmaram: "Nunca pensei que essa atividade fosse tão forte".

A exposição se seguiu por mais alguns alunos até que chegou a vez da aluna, nomeada aqui com o pseudônimo de Camila. Esta disse estar muito emocionada com o conto porque ela tinha achado muito bonito o fato do protagonista ter se encantado com um caminhãozinho de bombeiro. Ela disse que tem um priminho que é muito fechado pelos pais, muito trancado em casa e que não tem acesso a brincadeiras ao ar livre, passeios e a convivência com amigos. Num dia, Camila levou esse priminho para tomar um milk shake. Ao receber o copo de milk shake, o garotinho perguntou como se fazia para tomar, Camila disse que ele deveria colocar o canudinho na boca e chupar e 
mostrou com o próprio milk shake. O priminho, então, fez como Camila o havia ensinado e teve uma alegria muito intensa ao ver que o sorvete chegava à sua boca pelo canudinho. Ao ver a alegria do priminho com o milk shake, Camila disse:

\begin{abstract}
Professora, eu não sei o nome desse sentimento que eu tive quando eu vi meu priminho naquela alegria toda com o milk shake dele, mas foi o mesmo sentimento que eu tive ao ver o personagem do conto com o caminhão de bombeiro. É bonito de ver como algumas pessoas conseguem ser feliz com tão pouco. É como se esse pouco fosse muito, só que a maioria das pessoas não sabem ver. Ao mesmo tempo que eu vi isso, eu me senti um pouco culpada, porque eu tenho muitas coisas, meus pais me levam para passear, eu não passo necessidade não, mas eu não sei valorizar as coisas como o meu priminho $^{18}$. (informação verbal)
\end{abstract}

Diante dessa colocação, a professora achou importante aproveitar a oportunidade para nomear o sentimento que estava sendo vivenciado. A professora, então, perguntou à sala se mais alguém ali compreendia o que Camila estava sentindo. Toda a sala levantou a mão em resposta afirmativa. Assim, a professora perguntou aos alunos como eles nomeariam esse sentimento. Dentre todas as respostas que apareceram, a que eles mais gostaram, que acharam que nomeava melhor o sentimento foi "sentir a grandeza das coisas pequenas".

Após mais algumas colocações, chegou o momento da aluna Antígona se colocar, a exposição dela foi um pouco diferente das feitas até então, pois Antígona pegou um único elemento da narrativa e, através dele, realizou uma viagem em suas lembranças. Antígona disse que, ao descobrir que o protagonista do conto tinha encontrado um caminhãozinho de bombeiro, ela se recordou de seu avô, pai de seu padrasto, que, quando ela era muito pequena, havia levado ela e o primo para visitar o corpo de bombeiros da cidade. Ela disse que tinha gostado muito do passeio e que o seu avô era uma pessoa muito amorosa, mas que, conforme Antígona foi crescendo ela passou a se distanciar de seu avô, em suas palavras, Antígona afirmou até mesmo desprezá-lo. Esse avô faleceu, e Antígona afirmou passar por uma dificuldade muito grande diante da culpa por ter se distanciado, por ter desprezado, por não ter dado espaço para que os dois passassem mais tempo juntos. Antígona chorou muito em seu relato e, entre lágrimas, mostrou o retrato do avô colado no Diário e disse que agora só restou o passeio no corpo de bombeiros em sua memória. Muitos outros alunos começaram a chorar diante da exposição de Antígona e alguns outros afirmaram viver com o mesmo

\footnotetext{
${ }_{18}$ Aluna Camila em manifestação oral na ocasião da aula de Histórias de Leitura, 06 de Novembro de 2018.
} 
sentimento de culpa por terem se distanciado de alguém que hoje é falecido. Foi interessante observar que surgiu aí um movimento de acolhimento, os alunos que afirmaram ter o mesmo sentimento de Antígona passaram a se colocar dizendo o que eles fazem ou pensam para lidar com a culpa. Antígona, diante do acolhimento e da partilha dos colegas que sentiam o mesmo, se sentiu melhor, parou de chorar, agradeceu o apoio dos colegas e disse: "Nossa, de repente a gente ficou tão amigo, seria tão bom se fosse sempre assim." (aluna Antígona na ocasião da aula de Histórias de Leitura, 06 de Novembro de 2018). A fala foi seguida pelo riso de todos.

Além das colocações registradas, a grande maioria das outras manifestações falavam sobre sofrimento, revolta e raiva dos alunos em relação ao bullying que, tanto eles como o protagonista do conto passaram; a tristeza advinda de outros sofrimentos passados por eles ou por conhecidos em partos; lembranças alegres e tristes associadas a elementos do conto como o caminhãozinho de bombeiro e a tristeza ao constatar que, assim como o personagem, muitos deles também dependem do Programa Bolsa Família.

Assim, nas anotações da professora para a realização do Itinerário de Discussão constaram os seguintes itens:

\begin{tabular}{|l|l|}
\hline \multicolumn{1}{|c|}{ Sentimento/emoção } & \multicolumn{1}{c|}{ Parte do conto } \\
\hline $\begin{array}{l}\text { Raiva, revolta, remorso (através da } \\
\text { manifestação de lembranças). }\end{array}$ & $\begin{array}{l}\text { Momento em que o protagonista sofre } \\
\text { Bullying. }\end{array}$ \\
\hline $\begin{array}{l}\text { Tristeza, identificação (através da } \\
\text { manifestação de lembranças) }\end{array}$ & $\begin{array}{l}\text { Pelo protagonista ter passado por } \\
\text { complicações na parto. }\end{array}$ \\
\hline $\begin{array}{l}\text { Estranhamento. } \\
\text { Medo, susto, culpa. }\end{array}$ & $\begin{array}{l}\text { Pelo conto utilizar-se de linguagem não } \\
\text { padrão. }\end{array}$ \\
\hline Identificação, tristeza, remorso. & $\begin{array}{l}\text { Por pensar que o protagonista iria praticar } \\
\text { suicídio ou iria atirar em seus colegas na } \\
\text { escola. }\end{array}$ \\
\hline Surpresa, alívio, alegria, vontade de & $\begin{array}{l}\text { Pelo protagonista se preocupar em não } \\
\text { faltar para não perder o auxílio do } \\
\text { Programa Bolsa Família. }\end{array}$ \\
\hline
\end{tabular}




\begin{tabular}{|c|c|}
\hline $\begin{array}{l}\text { chorar de emoção, coração apertado, nó na } \\
\text { garganta. }\end{array}$ & $\begin{array}{l}\text { tratava de uma arma, mas de um } \\
\text { caminhãozinho de bombeiro. }\end{array}$ \\
\hline $\begin{array}{l}\text { Curiosidade, ansiedade, suspense, dúvida, } \\
\text { preocupação. }\end{array}$ & $\begin{array}{l}\text { Por querer saber se o brinquedo era } \\
\text { mesmo uma arma ou se era outra coisa. }\end{array}$ \\
\hline $\begin{array}{l}\text { Confusão, sentimento de ter sido } \\
\text { enganado. }\end{array}$ & $\begin{array}{l}\text { Por ter certeza que o protagonista tinha } \\
\text { achado uma arma ao invés do } \\
\text { caminhãozinho de bombeiro }\end{array}$ \\
\hline Identificação. & $\begin{array}{l}\text { Pela rotina do personagem e por sua } \\
\text { realidade socioeconômica. }\end{array}$ \\
\hline $\begin{array}{l}\text { Saudosismo/saudade, culpa, egoísmo (por } \\
\text { se lembrar de um ente querido que já } \\
\text { faleceu ou por observar alguém em uma } \\
\text { situação difícil). }\end{array}$ & $\begin{array}{l}\text { Por pensar em coisas associadas a algum } \\
\text { elemento do conto como o caminhãozinho } \\
\text { de bombeiro. }\end{array}$ \\
\hline Felicidade. & Pelo conto ser engraçado e descontraído \\
\hline Vergonha & $\begin{array}{l}\text { Por pensar que o protagonista seria capaz } \\
\text { de cometer suicídio ou matar os colegas, } \\
\text { por pensar que o protagonista tinha } \\
\text { achado uma arma e que usaria essa arma } \\
\text { só porque ele é pobre. Por notar como eu } \\
\text { sou preconceituoso. }\end{array}$ \\
\hline Admiração, confusão, decepção. & $\begin{array}{l}\text { Ao ver que o personagem ficou tão } \\
\text { encantado por causa de um } \\
\text { caminhãozinho de bombeiro. }\end{array}$ \\
\hline Encantamento & $\begin{array}{l}\text { Por pensar no que o caminhãozinho de } \\
\text { bombeiro significava para Gigante. }\end{array}$ \\
\hline Vontade de ler de novo & $\begin{array}{l}\text { Para ver se eu observo aquilo que os meus } \\
\text { colegas falaram e eu não notei. }\end{array}$ \\
\hline
\end{tabular}

Manifestação dos alunos nas Histórias de Leitura para serem usadas no Itinerário de Discussão

De posse dessas anotações, a professora e seus alunos seguiram para o Itinerário de Discussão. 


\section{3. $3^{\text {a }}$ Etapa: Itinerário de Discussão}

Em termos de organização para um estudo textual um pouco mais teórico e reconhecendo a questão central da dificuldade de nomear para o processo de humanização, a professora decidiu iniciar o estudo do texto por uma perspectiva lexical.

Tudo teve início com um convide da professora para que os alunos elencassem os elementos presentes no texto que os fizeram pensar que o "brinquedo" achado por Gigante era uma arma. A princípio, os itens mencionados foram os substantivos "cano", "gatilho" e o verbo "sacar". Ao perguntar aos alunos se havia mais alguma coisa, um aluno respondeu que o fato do personagem Gigante sofrer bullying fez com que ele pensasse que era uma arma mesmo e que o protagonista iria atirar nos colegas que praticavam bullying contra ele. Assim, professora foi até a lousa e fez a seguinte anotação:

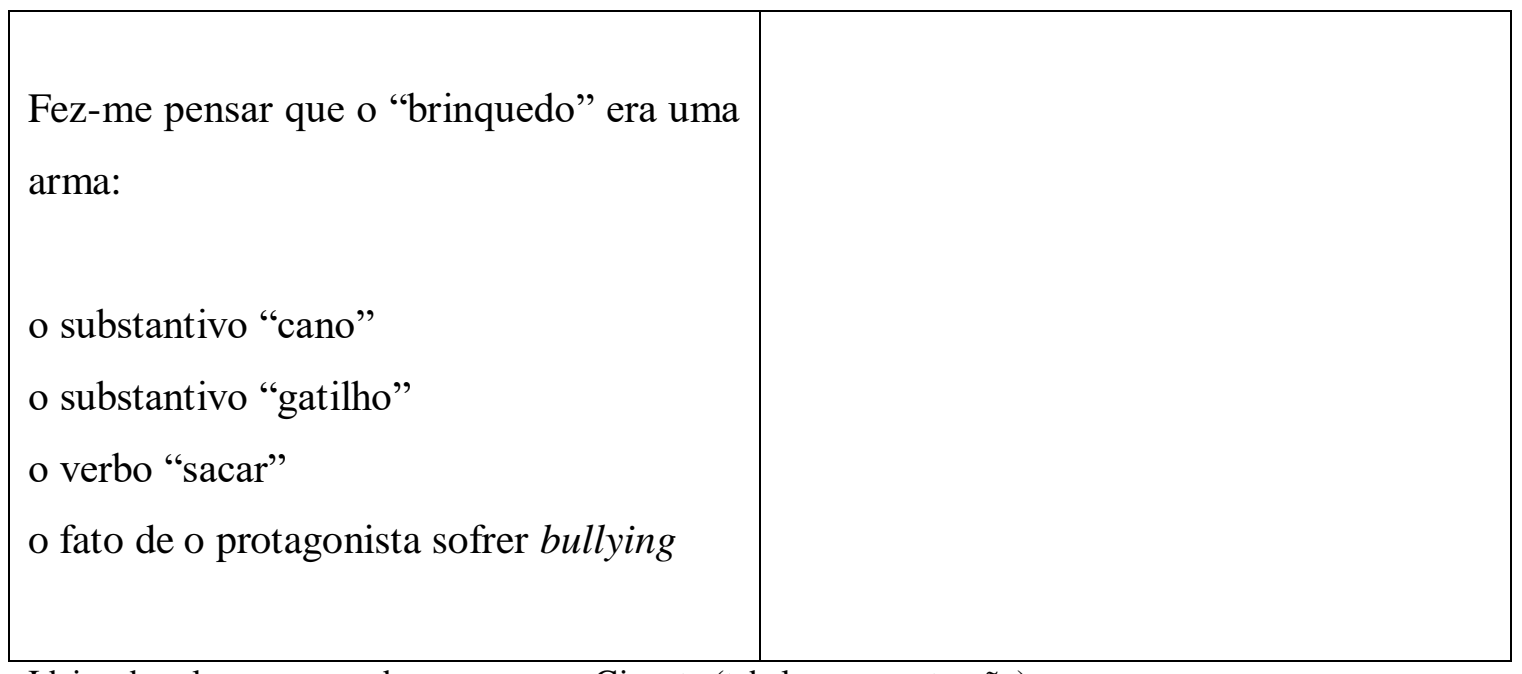

Ideias dos alunos acerca do personagem Gigante (tabela em construção)

Com essas anotações, a professora passou a perguntar pelo motivo que estabelecia a relação entre as palavras elencadas e a arma. Os alunos responderam que as palavras "cano" e "gatilho" os fizeram pensar na arma por se tratarem de palavras que são empregadas para nomear as partes de uma arma. Já o verbo "sacar" é comumente utilizado junto do substantivo "arma". A professora então entregou alguns dicionários e pediu que os alunos encontrassem o sentido das palavras elencadas. Os sentidos elencados foram: 
Cano: sm. 1. Construção tubular para condução de água, gáz etc. 2. Tubo de armas de fogo. 3. Parte tubular de bota ou luva.

Gatilho: sm. Peça dos fechos de arma de fogo que, puxada, efetua o disparo.

Sacar: v.t.d. 1. Tirar para fora à força, a puxões, com violência. 2. Emitir (cheque). 3. Retirar (dinheiro) de instituição financeira. 4. Gír. Entender, compreender. T.i. 5. Sacar (1). Int. 6. Bras. Pop. Mentir. 7. Esport. Dar saque ou ter o direito de dá-lo. (FERREIRA, 2004. p. 206, 429 e 720)

Depois de lidas essas definições, a professora perguntou à turma se todas essas palavras estavam realmente ligadas ao significado da palavra arma. Todos os alunos responderam afirmativamente. Alguns alunos observaram, ainda, que, embora a palavra “arma” não apareça na definição do verbo "sacar", eles já conheciam a construção "sacar uma arma" e que, na definição, quando se diz "Tirar para fora à força, a puxões, com violência", muito comumente, o objeto em questão se trata de uma arma.

Assim, a professora passou a considerar o fato de o protagonista sofrer bullying. A professora pediu aos alunos que levantassem a mão aqueles que já haviam sofrido bullying. A grande maioria da sala levantou a mão. A professora perguntou se, dentre aqueles que já haviam sofrido bullying, se alguém já havia pensado em atirar nos colegas que faziam o bullying. Nenhuma das mãos se levantou. A professora, então, perguntou se o fato de passar pelo bullying leva a ações violentas tais como atirar nos outros. Os alunos responderam que normalmente não, pois se cada um que passasse pelo bullying atirasse em quem o pratica não haveria mais crianças na escola. Disseram ainda que embora eles conheçam casos de atentados violentos contra escolas resultantes do bullying, tais ocorrências são ínfimas perto da grande ocorrência de bullying que se verifica na realidade escolar. Os próprios alunos sugeriram que a professora apagasse a anotação sobre o bullying da lousa.

A seguir, a professora perguntou o que havia de bom no personagem Gigante que foi observado durante as Histórias de Leitura. Os alunos foram nomeando as características do protagonista e a professora foi registrando na lousa, de forma que, ao final, a anotação ficou conforme a tabela a seguir: 


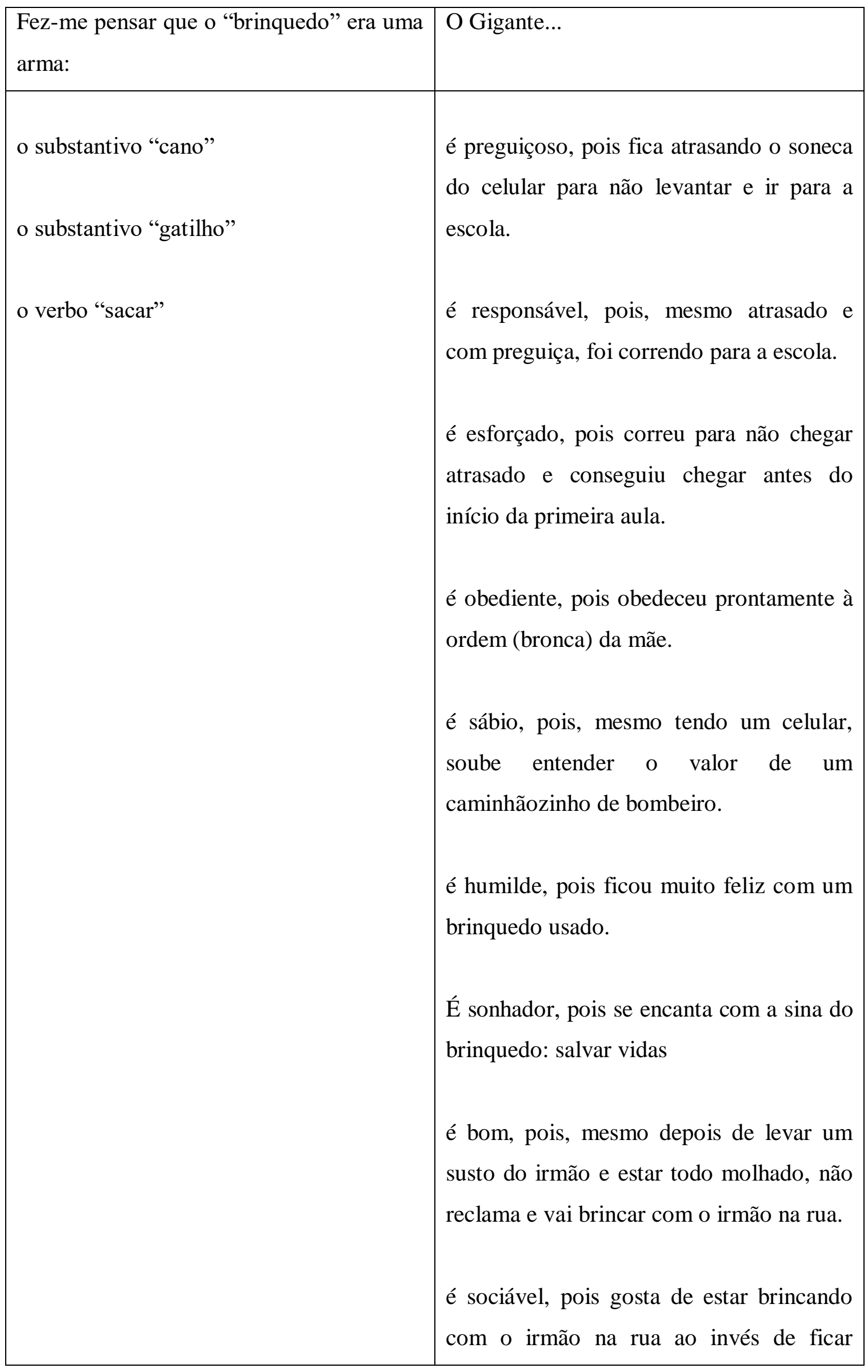




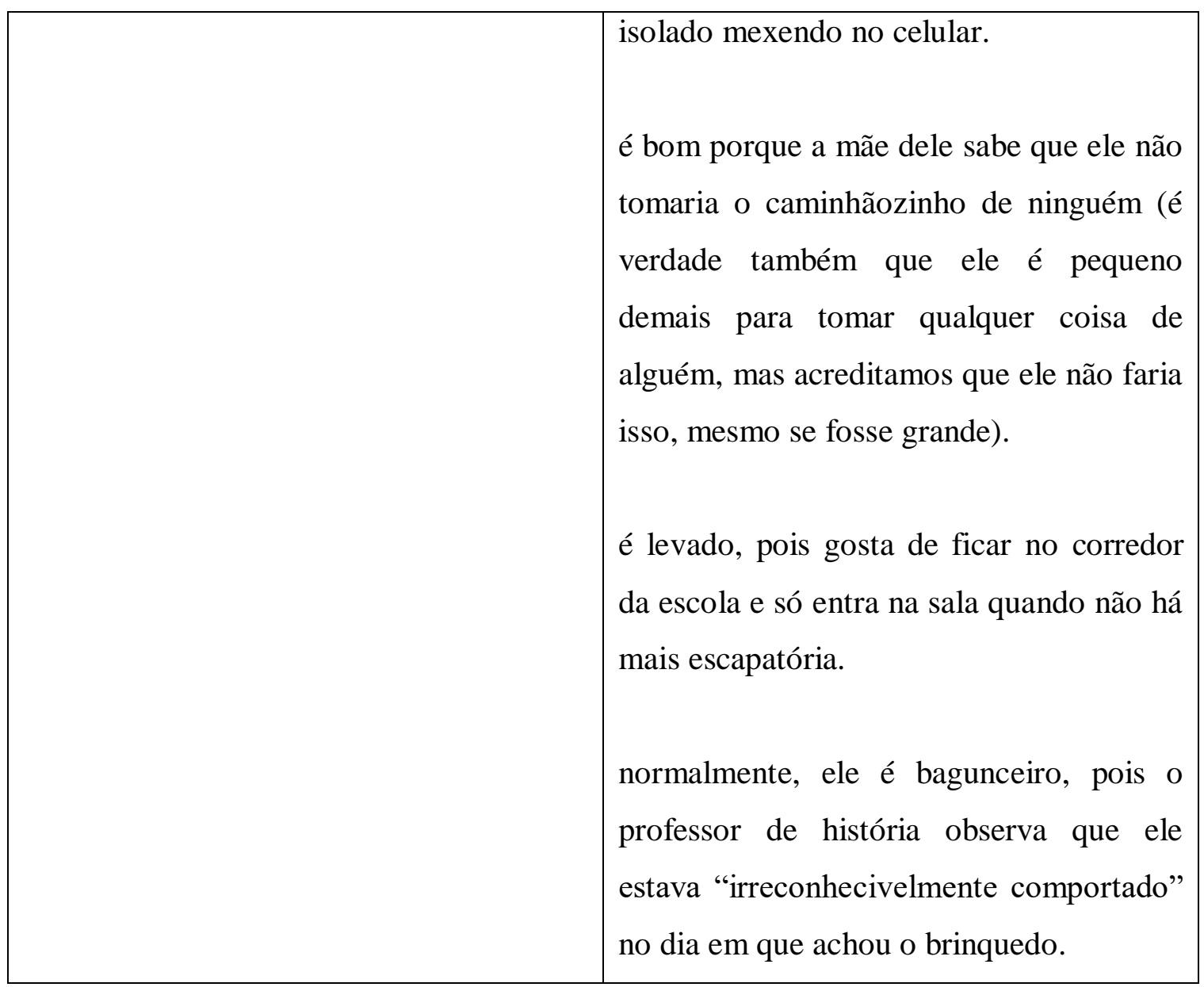

Ideias dos alunos acerca do personagem Gigante (tabela completa).

Depois de todas essas observações elencadas pelos alunos, a professora perguntou o que eles achavam do Gigante. A sala toda respondeu que achava o personagem um menino normal, nem bom, nem ruim. O aluno, nomeado aqui como Edilson, fez a seguinte observação:

Professora, eu achei o Gigante um menino bem real, ele não é essas coisas perfeitas de filme de princesa, não, ele é bem ser humano real, igual a gente. Às vezes faz umas coisas boas, às vezes pisa na bola. Que nem eu, eu? Eu só não, todo mundo aqui fica atrasando o soneca depois vem correndo que nem um louco gritando pra tia não fechar o portão. E isso, esses... alguns errinhos assim não faz da gente pessoas capazes de atirar nos outros ${ }^{19}$. (informação verbal)

Logo após essa manifestação, outro aluno, nomeado aqui como Fábio, disse:

Não, e, tipo, olha só quantas coisas a gente tinha para pensar que o Gigante não atiraria em ninguém nem nele mesmo, que ele não pegaria uma arma ou, se pegasse, entregaria a algum adulto. E só tem três coisas, não é nem três

\footnotetext{
${ }^{19}$ Aluno Edilson em manifestação oral na aula do dia 08 de novembro de 2018.
} 
coisas, três palavras, que fazem a gente pensar que o Gigante ia cometer uma tragédia e, mesmo assim, a gente acredita na tragédia ${ }^{20}$. (informação verbal)

Nesse momento, outro aluno, nomeado aqui como Gustavo pede a palavra e complementa:

\begin{abstract}
Não é só a gente não, tipo, é todo mundo. Tem um milhão de coisa boa e uma coisa ruim só, todo mundo presta mais atenção na coisa ruim e nem vê as coisas boas. Professora, lá em casa, tá todo mundo de bucho cheio e tá todo mundo reclamando. A senhora lembra que desocuparam os barraquinhos que tinha lá perto das torre de alta tensão? Então, eu fiquei pensando, caramba podia ser a minha família. Eu tinha uns amigo que morava lá, né? E, tipo, os cara vinha pra escola pra comer a merenda, o camarada meu fazia aquele prato monstro, todo mundo ficava zoando, mas, tipo, ele sabia que se ele não comece bem aqui na escola, que que ia ser dele o resto dia professora? Eu nunca passei fome, professora, já passei muita vontade das coisa, mas fome, fome mesmo, nunca passei não, e assim, eu agradeço a Deus por isso, e lá em casa, todo mundo, de bucho cheio, fazendo fofoca, reclamando, enchendo o saco, "cê é loco", em vez de prestar atenção na coisas boas da vida, fica ligando pra umas coisa nada a ver ${ }^{21}$. (informação verbal)
\end{abstract}

O debate seguiu por longo tempo, as colocações dos alunos a partir de então, passaram a versar sobre como, tanto eles como os seus familiares e conhecidos, acabam emitindo julgamentos equivocados dada a tendência de se focalizar muito mais nas coisas ruins do que nas boas.

\title{
3.4. $4^{\mathrm{a}}$ Etapa: Histórias de Convivência
}

Seguiu-se, então, para o encontro de avaliação da sequência proposta. Novamente, formou-se a roda de conversa e a palavra foi dada a cada um dos trinta e cinco alunos presentes. Antes do início da partilha das avaliações, a professora orientou que cada um dos alunos a se manifestar deveria iniciar a sua fala com uma única palavra ou expressão que, para cada um deles, representasse o processo como um todo. Depois da escolha da palavra ou expressão, o aluno poderia explicar melhor a escolha da palavra e o seu ponto de vista em relação ao processo. Novamente, pontuar o início do processo por uma perspectiva lexical é importante por tentar trabalhar a questão da dificuldade de nomear. Além disso, a escolha de uma única palavra ou expressão é importante para realizar no aluno um esforço de síntese, um movimento de reordenação e conclusão de um processo, tendo em vista o objetivo central das Histórias de Convivência que é o

\footnotetext{
${ }^{20}$ Aluno Fábio em manifestação na aula do dia 08 de novembro de 2018.

${ }^{21}$ Aluno Gustavo em manifestação na aula do dia 08 de novembro de 2018.
} 
balanço final e o desfecho de uma sequência de reuniões pautadas sobre uma determinada obra literária.

Cada vez que um aluno colocava a sua palavra ou expressão síntese, a professora fazia uma anotação na lousa, de forma que, ao final das avaliações, o quadro se apresentou como a seguir:

\begin{tabular}{|c|c|c|}
\hline Espetacular & Abertura & Gigante(sco) \\
Especial & Incrível & Modificador \\
União & Empolgante & Revolucionário \\
Libertador & Inesquecível & Iluminador \\
Legal & Sentimental & Calmante \\
Diferente & Difícil & Confortante \\
Importante & Desafiador & Inquietante \\
Interessante & Necessário & Assustador \\
Ótimo & Profundo & Descoberta \\
& & \\
\hline
\end{tabular}

Estudo de síntese lexical acerca da intervenção pedagógica aplicada

Muito embora houvesse trinta e cinco alunos presentes no dia, oito alunos repetiram palavras já mencionadas pelos colegas que se manifestaram anteriormente, de forma que no elenco das palavras apresentadas, aparecem apenas vinte e sete manifestações.

Em sua totalidade, as avaliações realizadas pelos alunos foram bastante positivas, revelando não apenas a importância pedagógica do processo, mas também a sua contribuição em um processo formativo humano, de investigação, descoberta e fascínio em relação a uma vida interior.

\subsection{Análise dos Resultados}

Inicialmente, é importante observar o fato de que a análise que a seguir se apresenta é apenas uma elaboração inicial, sem nenhuma pretensão conclusiva a não ser o fato de iniciar um diálogo, uma reflexão passível de erros e acertos, absolutamente aberta a novas considerações. Nas palavras de Cunha (2009): 
Saber que estamos na posição de interpretante dinâmico significa ter a humildade de reconhecer que toda e qualquer interpretação singular é sempre incompleta e falível. No entanto, é a consciência dessa falibilidade que nos mune de energia e empenho para a análise cuidadosa do objeto de estudo, para o conhecimento dos conceitos e sua operacionalidade. (CUNHA, 2009. p. $24-25)$

Com a mesma humildade, reconheço, no presente trabalho, toda a problemática existente em torno da questão do eu testimonial formulada por Clifford Geertz, observada em relação ao fato da analista ver a si mesma inserida, diretamente, no objeto a ser analisado. Em relação ao trabalho etnográfico, Geertz irá dizer:

[...] as representações da pesquisa de campo do etnógrafo, concebida como uma experiência pessoal, uma concepção do eu através do desvio pelo outro, são situadas no centro da autor-ização. [...] O dilema da sinceridade está à espreita de todos os que passam por esse caminho. (GEERTZ, 2005. p. 131)

Finalmente, buscando eliminar a confusão resultante da substituição do nome real dos alunos produtores dos Diários por letras e na tentativa de tornar a análise algo mais humanizada, tomou-se o cuidado de atribuir, a cada um dos alunos, um pseudônimo mitológico e/ou literário, baseado naquilo que eles próprios apresentaram de mais significativo (aos olhos da analista) em seus registros.

- Diário de Leitura No 1, aluna Antígona (Disponível no anexo B)

Sobre a Leitura Livre

Em relação à Leitura Livre, observa-se que Antígona elabora sua expressão escrita com base no registro de três lembranças: a primeira referindo-se a um filme que ela assistiu, a segunda retomando a fala de seu irmão e a terceira mencionando um passeio no qual seu "avô", pai de seu padrasto, levou-a para conhecer a base do corpo de bombeiros:

Quando eu comecei a ler, me lembrei do filme "Extraordinário", por ele ter nascido com dificuldades de desenvolvimento assim como Auggie, o personagem do filme, então eu imaginei o gigante como o Auggie. [...] me lembrei de quando meu irmão disse que preferia um caminhão de bombeiro do que um vídeo game [...] me fez lembrar também do "meu avô", não era de sangue, mas era de coração e, caramba mano, que saudade, me lembrei dele porque teve uma vez que ele levou eu e meu primo no lugar onde os 
bombeiros ficam, treinam... e foi muito louco esse dia $[\ldots]^{22}$. (informação verbal)

A leitura que traz à tona um movimento de lembrança de fatos vividos é bastante importante para a humanização na medida em que se reconhece o ser humano vivente como alguém que acumula experiências e reflete acerca dessas experiências, extraindo delas significação. Ao retomar suas lembranças e significá-las e/ou ressignificá-las, está-se empreendendo uma via na contramão do angustiante esvaziamento da experiência proposto por Agamben (2005).

É importante observar que a leitura que traz à tona lembranças vai ao encontro com a própria vida do leitor, fazendo com que ele encare o arquivo de suas vivências passadas a partir de uma nova perspectiva, construindo significados onde antes não havia, sob a perspectiva da resiliência humana, ou ressignificando-os. A leitura promove o encontro do leitor consigo mesmo, num tempo passado, quando ele agia conforme um conjunto de valores e pressupostos que, talvez tenha mudado, talvez não. O fato é que ao promover tal encontro, o leitor encontra-se consigo mesmo como que diante de um espelho e se torna capaz de estabelecer um movimento reflexivo sobre quem se é, sobre aquilo que já se viveu e, consequentemente, sobre quem se deseja ser.

Após essa observação de si mesmo num tempo passado, o leitor passa a elaborar suas lembranças em palavras para colocá-las no Diário, tal como o feito por Antígona, o que implica uma reelaboração, uma tradução em novas palavras, uma nova reflexão diante do fato vivido. De acordo com Ecléa Bosi, na obra Memória e sociedade lembranças de velhos:

Na maior parte das vezes, lembrar não é reviver, mas refazer, reconstruir, repensar, com imagens e ideias de hoje, as experiências do passado. A memória não é sonho, é trabalho. Se assim é, deve-se duvidar da sobrevivência do passado, "tal como foi", e que se daria no inconsciente de cada sujeito. A lembrança é uma imagem construída pelos materiais que estão, agora, à nossa disposição, no conjunto de representações que povoam nossa consciência atual. Por mais nítida que nos pareça a lembrança de um fato antigo, ela não é a mesma imagem que experimentamos na infância, porque nós não somos os mesmos de então e porque nossa percepção alterouse e, com ela, nossas ideias, nossos juízos de realidade e de valor. O simples fato de lembrar o passado, no presente, exclui a identidade entre as imagens de um e de outro, e propõe a sua diferença em termos de ponto de vista. (BOSI, 1994. p. 55)

\footnotetext{
${ }^{22}$ Aluna Antígona, Diário de Leitura, Leitura Livre.
} 
Observe que, além de um trabalho de renomeação e, portanto, de ressignificação, o encontro com as memórias lança bases sobre as quais se dão a sustentação de fortes elementos identitários, o que é fundamental para a humanização. É ancorado sobre o fluxo de reflexão e entendimento em relação àquilo que se viveu, e as representações pessoais que se constroem a partir dessa experiência, que se concebe quem se é. Obviamente, nenhum ser humano é algo acabado, estamos todos em constante processo de construção, de entendimento acerca de nossas experiências e, portanto, em curso de mudança e a reflexão sobre aquilo que se viveu é de fundamental importância para a fluídica concepção de quem se é em cada momento. Assim, ter um momento para a reflexão diante das lembranças e as representações construídas a partir destas é capital para a compreensão e para a aprendizagem sobre quem se é e quem se deseja ser. É importante constatar que o movimento de recuperação de Antígona, diante de suas memórias, leva suas considerações a um movimento de culpa e saudade que sinaliza um intenso desejo de mudança, o que ficará nítido no exame de suas colocações no encontro de Histórias de Leitura, considerado a seguir.

Mesmo constatando a importância de movimentos reflexivos em torno da retomada de memórias e de lembranças para a formação e a aprendizagem do ser humano sobre si mesmo e acerca do ser humano que se deseja ser, a escola reserva muito pouco, em seu currículo ou em sua prática, para o trabalho com a reflexão em torno das vivências passadas. Em termos curriculares, há apenas a consideração das memórias e das lembranças, de forma muito fragmentada, no sétimo ano quando é proposto o estudo do gênero relato de experiência. Diante disto, o método LabLei promove um encontro com a lembrança e a reflexão em torno da lembrança de forma mais frequente e integrada a qualquer que seja a temática abordada nas aulas, indo contra a dinâmica de fragmentação de conteúdos colocada pela realidade curricular.

Antes de passar para a consideração das Histórias de Leitura, há mais uma observação a ser feita sobre o registro da aluna acerca da Leitura Livre: a sua identificação como o personagem do conto.

[...] então eu li essa parte de novo onde dizia que ele havia encontrado o brinquedo, e entendi o porque de tanta euforia, pois me lembrei que também sou assim, sempre que encontro, ganho, compro etc. alguma coisa, a ansiedade toma conta de mim e a vontade de contar para todos ${ }^{23}$. (informação verbal)

\footnotetext{
${ }^{23}$ Aluna Antígona, Diário de Leitura, Leitura Livre
} 
Ao contrário do movimento de reflexão em torno das memórias que nos colocam diante de um espelho cuja observação recai sobre si mesmo em um momento passado, a identificação do leitor com o personagem do conto proporciona um olhar sobre si mesmo através da consideração do outro. Esse movimento de identificação com o personagem vai diretamente ao encontro do forte caráter exemplar presente nas narrativas desde as narrativas épicas da Grécia Antiga.

Observe que a aluna reconhece um aspecto de si ao observar o mesmo no personagem da trama e, muito embora essa identificação não esteja relacionada a aspectos sociais, ela pode perceber que alguém que tem algo como ela foi digno de representação artística literária, o que traz para o leitor certa valorização. Eis aí a importância do contato do aluno da escola pública com a literatura marginal. Esta, ao garantir um espaço de voz e reconhecimento social das realidades periféricas, coloca o aluno da escola pública, das periferias urbanas, como personagem de obras literárias, legitimando sua realidade por uma perspectiva artística e afirmando a possibilidade do aluno ter voz acerca de si mesmo. Sobre essa possibilidade de a leitura promover semelhante inclusão e valorização, Michèle Petit afirma:

Compreendemos que por meio da leitura, mesmo esporádica, podem estar mais preparados para resistir aos processos de marginalização. Compreendemos que ela os ajuda a se construir, a imaginar outras possibilidades, a sonhar. A encontrar um sentido. A encontrar mobilidade no tabuleiro social. A encontrar a distância que dá sentido ao humor. E a pensar, nesses tempos em que o pensamento se faz raro. (PETIT, 2009. p. 19)

O sentimento de dignidade é importante não apenas por ser a força motriz da ação humana em busca de melhores condições de vida, mas também, mostra-se como uma das premissas maiores para a humanização na medida em que o ser vivente só irá à busca de humanização no momento em que se entender digno dela. A quase totalidade da história escolar está fortemente enraizada sobre objetos de ensino derivados de uma visão hegemônica branca, masculina e bem servida financeiramente. Diante dessa grandiosa fonte de nulidade, a maioria da população brasileira não se vê representada nas esferas discursivas apresentadas pela escola e, portanto, se vê apartada da possibilidade de viver uma experiência artística fruitiva quando em contato com a obra literária, principalmente em um momento em que o leitor está em formação. Para os alunos envolvidos na intervenção pedagógica em análise, a reflexão sobre o clássico será uma possibilidade assim que eles se entenderem dignos de tal e, para tanto, a 
passagem pela identificação com personagens mais próximos à sua realidade é um passo importante. Ver a si mesmo em Gigante é um exercício interessante para, a seguir, ver a si em Raskolnikóv, Dante ou Riobaldo.

Com base nas observações tecidas até o presente momento, considera-se que, no item Leitura Livre do Diário de Leitura em análise, Antígona realizou um interessante movimento de encontro com suas lembranças, na medida em que sua reflexão, nomeação e ressignificação foram contra o esvaziamento da experiência e intensificaram suas vivências a favor da humanização. No mesmo sentido, a sua identificação com o personagem foi um acontecimento capaz de colocá-la em posição de enxergar-se através do outro e entender-se digna de representação literária artística.

\title{
Sobre as Histórias de Leitura
}

Em relação às Histórias de Leitura, pode-se observar que Antígona, ao empreender reflexão e ressiginificação em torno de suas lembranças, acabou por manifestar um desejo de mudança de atitude orientado por um forte senso ético e afetivo. Observe a sua contribuição oral no encontro de Histórias de Leitura:

\begin{abstract}
Então né, tipo, quando eu tava lendo, o que mais me tocou na leitura, foi esse negócio de bombeiro, porque quando eu era pequena, (a aluna começa a falar com a voz embargada) meu vô de coração, o pai do meu padrasto, ele levou eu e o meu primo pra conhecer (a aluna suspende a fala a chora, logo retoma o seu discurso chorando) o lugar dos bombeiros. A gente foi pra conhecer lá, pra ver o canil, mas o canil não deu pra gente ver. Daí, foi mó legal conhecer lá, e ficou a promessa de ir ver o canil, mas não deu porque o meu vô morreu antes de rolar o rolê. Mas lembrá disso é muito difícil pra mim, falar sobre isso é difícil, mas eu sinto que eu preciso, porque eu era distante do meu vô, eu não deixava ele chegar em mim, mas aí, agora ele morreu, faz tempo já, mas eu queria ter vivido mais com ele, ter conversado mais, ter ouvido as histórias dele, sabe? E eu sinto muita saudade, mas o que mata é a culpa de não ter deixado ele se aproximar ${ }^{24}$. (informação verbal)
\end{abstract}

No caso da contribuição oral da aluna Antígona, reproduzida acima, observa-se que a questão essencial da experiência humana considerada é a culpa e a saudade que, no caso da aluna em observação, apareceu diante do fato de ter se negado uma aproximação maior em relação ao avô e da constatação da impossibilidade dessa aproximação agora. Ao contrário da Antígona mitológica, que fica ao lado de seu pai, Édipo, acompanhando-o em sua decadência até o momento de sua morte, a Antígona

\footnotetext{
${ }^{24}$ Aluna Antígona, manifestação oral em sala de aula no encontro de Histórias de Leitura, 6 de novembro de 2018 .
} 
escolar se afastou de sua figura paterna e vive o arrependimento de sua indiferença. Retomando o conceito vygotskyano de perejivânia, o qual implica uma ressignificação a partir de uma experiência impactante, sobretudo, sob o ponto de vista afetivo, toda a dor e a saudade derivadas do sentimento de culpa impactam sobre Antígona de forma a fazê-la considerar a importância de uma mudança, talvez não uma mudança afetiva. Observe a continuação de sua fala:

\begin{abstract}
A culpa é o que mata, nossa! Essa fita aí, que aconteceu me faz pensar que, tipo, às vezes a única coisa que a gente tem com as pessoas que a gente ama é o momento, e nossa, quantos momentos eu podia ter curtido com o meu vô e não curti e, tipo assim, agora já era, não volta mais, não volta mais. A gente tem que aproveitar mais os momentos com as pessoas que a gente ama porque depois que a morte vem, já era, não adianta mais ${ }^{25}$. (informação verbal)
\end{abstract}

Como se verá a seguir, na análise do Diário de Leitura da aluna Alice, a colaboração de Antígona apresentou-se como uma contribuição valiosíssima para os colegas que passaram a considerar suas vivências a partir da vivência colocada por ela. Assim como se observou a construção de identificação entre Antígona e o personagem Gigante, no momento das Histórias de Leitura, Antígona, com seu discurso, assumiu a posição de fonte de outros movimentos identificatórios, o que conduz a análise ao estabelecimento da humanização através da abertura para si e para o outro, um dos efeitos do método LabLei, estabelecidos por Gallian. Contudo, aprofundar-se-á a análise sobre esse efeito na análise no Diário da aluna Alice. O que interessa observar agora é que, ao colocar para os colegas a sua experiência de leitura, Antígona acabou trazendo para a aula uma perspectiva, de alguma forma, relacionada com o conto lido, que não tinha sido alvo das considerações dos outros, mas que, por sua colocação, passou a ser. Instalou-se uma atmosfera de aprendizagem entre iguais. Em seu Diário, Antígona registra:

\footnotetext{
No encontro de história de leitura, o que mais me chamou a atenção foi ... na verdade duas coisas, a parte da saudade, claro, ver que meus colegas de classe sentiram o mesmo sentimento igual o meu no caso a saudade, e também a parte do perdão, que é algo muito importante, percebi também que devemos praticar a arte de perdoar as pessoas ${ }^{26}$. (informação verbal)
}

\footnotetext{
${ }^{25}$ Aluna Antígona, manifestação oral em sala de aula no encontro de Histórias de Leitura , 6 de novembro de 2018.

${ }^{26}$ Aluna Antígona, Diário de Leitura, Histórias de Leitura.
} 
Observe que a própria Antígona reconhece que os colegas não apenas consideraram a contribuição dela, mas também sentiram a saudade que ela revela na forma com a qual ela se colocou. Mais do que a oportunidade de oferecer algo aos colegas, Antígona afirma ter aprendido com as colocações dos outros quando ela menciona a importância do perdão. A escola perde muito no momento em que priva o aluno da possibilidade de manifestação dos seus pontos de vista sobre os objetos propostos. Normalmente, em uma aula centrada na análise do conto Um novo brinquedo, as manifestações de Antígona sobre a saudade de seu avô seriam muito rapidamente cerceadas na medida em que elas não mantêm, com o conto lido, uma relação direta e objetiva. No método LabLei, no momento da Leitura Livre e das Histórias de Leitura, há a possibilidade de uma aproximação com a obra narrativa de forma um pouco mais subjetiva e humana, valorizando a relação pessoal do leitor com o texto, explorando a experiência de leitura sincera. Há espaço para a polifonia das mais variadas leituras, como o colocado por Orlandi (2008) e Rouxel (2012).

Ao reconhecer e valorizar essa perspectiva de leitura, a escola ganharia em dois pontos principais: o primeiro em relação à construção de um leitor que sabe de suas possibilidades de leitura, que não tem medo de elaborar suas próprias colocações sobre a obra literária observada e que não entende a obra como uma realidade distanciada da sua; o segundo em relação à expansão dos horizontes de aprendizagem, uma vez que as colocações dos alunos trazem para a realidade escolar aquilo que eles consideram como questões dignas de reflexão, questões e angústias dignas do tempo e da realidade deles, o que liberta das amarras curriculares inflexíveis, da consideração do texto como um objeto de ensino e aprendizagem estático, além de promover uma injeção de interesse e entusiasmo nas aulas.

Assim, observa-se que o momento de Histórias de Leitura é uma oportunidade riquíssima de expansão do horizonte reflexivo oferecida aos alunos, baseada nas colocações dos próprios alunos em relação ao processo de leitura realizado. Ao considerar as colocações dos alunos, não apenas se instala uma atmosfera de aprendizado entre iguais, como também se coloca em evidência questões relativas à realidade deles, legitima-se a leitura feita, afirmando as possibilidades oferecidas pela polissemia da leitura e se nega a concepção curricular do texto como objeto de leitura estático, definido e limitado. 


\section{Sobre o Itinerário de Discussão}

Nessa altura da intervenção pedagógica, após um primeiro momento de relação mais subjetiva do leitor com o conto, passa-se a uma visão mais objetiva. Agora, o conto toma uma dimensão um pouco mais sólida, o que, absolutamente, não diminui o valor ou nega a legitimidade das exposições mais subjetivas feitas sobre ele anteriormente, no momento das Histórias de Leitura.

O Itinerário de Discussão é um momento mais orientado pelas questões colocadas pela professora acerca do texto. Os alunos procuram responder a tais questões com base nas informações contidas no texto, de forma explícita ou implícita.

Após a orientação oferecida pelas perguntas da professora e as colaborações dos alunos, Antígona registrou em seu Diário:

Eu concordo em tudo que a (nome de aluno) disse, e acho que foi muito bom ter essa parte da explicação da (nome de aluno) porque com isso eu consegui enxergar o texto com mais clareza, coisas que antes não tinha percebido, como, por exemplo, julgar o Gigante de forma errada pelas palavras do narrador e não pelas atitudes do personagem ${ }^{27}$. (informação verbal)

Observe que, novamente, o efeito estabelecimento da humanização através da abertura para si e para o outro aparece na abertura de Antígona em relação às considerações dos colegas sobre as perguntas colocadas pela professora. É interessante observar que, mesmo contando com uma parte inicial um pouco mais subjetiva, o método LabLei não negligencia as questões mais objetivas do conto, pelo contrário, ao conceder um espaço inicial de expressão da leitura pessoal, e ao colocar a leitura mais objetiva não como a leitura correta e absoluta, mas apenas como mais uma leitura possível, as guardas se desarmam e os alunos tendem a receber tal leitura de forma mais serena e tranquila. É grande a diferença que a aceitação das leituras pessoais pode oferecer: ao chegar com a imposição incisiva de uma "leitura oficial", geralmente distanciada das possibilidades de compreensão dos alunos, afirma-se uma incompetência leitora patente e, o que deveria ser uma experiência prazerosa, se torna afirmação absoluta da impossibilidade e incompetência do aluno em realizar a leitura esperada, a "leitura correta". Ao contrário, quando, primeiro, há um movimento de legitimação da leitura realizada pelo aluno e, logo após, a apresentação da leitura um pouco mais "objetiva" como mais uma possibilidade de leitura, os alunos tendem a não

\footnotetext{
${ }^{27}$ Aluna Antígona, Diário de Leitura, Itinerário de Discussão.
} 
apenas entenderem-se leitores eficientes, mas também tendem a compreender a leitura mais objetiva como mais uma possibilidade que, embora não tenha sido percebida por eles anteriormente, não anula a leitura realizada por eles. Assim, Antígona continua o seu registro no diário afirmando o prazer que teve ao descobrir uma nova possibilidade de leitura:

\footnotetext{
Acho que a terceira parte do diário foi uma das melhores, porque mesmo eu e meus colegas lendo o texto, só com a palavra da (nome de aluno) que eu consegui ver as coisas nítidas que até então eu não tinha percebido ${ }^{28}$ (informação verbal. Grifo nosso)
}

Assim, observa-se que o movimento de iniciar a sequência com a aceitação das leituras pessoais, elaboradas pelos alunos, e apresentar a leitura um pouco mais objetiva como apenas mais uma possibilidade de leitura, acaba por ir contra o movimento cruel e silencioso que afirma um distanciamento entre seres humano, a incapacidade, a impossibilidade do aluno leitor desenvolver as suas capacidades leitoras e, um dia, ou talvez, agora mesmo, chegar à apreciação artística da experiência da leitura de uma obra mais complexa como o clássico.

Sobre as Histórias de Convivência

As Histórias de Convivência apresentam-se como um momento de balanço, de avaliação de toda a intervenção experimentada pelos alunos. Em relação à avaliação realizada por Antígona, tem-se o seguinte:

Eu gostei muito da atividade pelo fato de eu conseguir falar com meus colegas coisas que não consigo com meus pais, como por exemplo o assunto do "meu avô", é muito delicado lá em casa, então prefiro nem tocar no assunto. Mas na sala eu consegui me abrir e falar tudo o que tinha vontade ${ }^{29}$. (informação verbal)

Observe que Antígona afirma ter tido uma experiência bastante positiva com a intervenção por, em primeiro lugar, ter encontrado um espaço propício para expressar aquilo que ela tinha vontade de dizer, mas que nunca havia encontrado situação apropriada. Nesse momento de fala de Antígona, no qual ela consegue expor, consegue traduzir em palavras aquilo que tem vontade de dizer, nomear aquilo que a angustia, seu

\footnotetext{
${ }^{28}$ Aluna Antígona, Diário de Leitura, Itinerário de Discussão.

${ }^{29}$ Aluna Antígona, Diário de Leitura, Histórias de Convivência.
} 
desabafo é recebido com respeito e carinho pelos colegas, como ela mesma mencionou anteriormente "ver que meus colegas de classe sentiram o mesmo sentimento igual o meu no caso a saudade" (Aluna Antígona, Diário de Leitura, Histórias de Leitura), tudo isso configura mais um efeito do LabLei: o efeito terapêtico. Sobre esse efeito, Gallian irá dizer que "[...] é próprio do terapêutico também repertoriar aquele que busca a cura com novos remédios, que no caso da experiência do LabLei são as próprias palavras, as próprias histórias que têm um poder mágico e libertador" (GALLIAN, 2017. p. 197).

No mesmo sentido, Petit afirma, acerca dos leitores observados por ela:

\begin{abstract}
Estão em busca de palavras que permitam domesticar seus medos e respostas às questões que os atormentam. Exploram em diferentes direções, sem levar em conta rubricas e linhas de divisão entre obras mais ou menos legítimas. E encontram às vezes o apoio de um saber, ou, em um testemunho, em um relato, um romance, um poema, o apoio de uma frase escrita, de uma estruturação. Ao poder dar um nome aos estados que atravessam, podem encontrar pontos de referência, apaziguá-los, compartilhá-los. E compreendem que esses desejos ou esses temores que acreditavam serem os únicos a conhecer, foram experimentados por outros, que lhes deram voz. [...] Ele está à espreita, à caça de palavras: trata-se, talvez, antes de tudo, de uma busca de simbolização. (PETIT, 2013. p. 44, 45)
\end{abstract}

Ao nomear, ao conceber aquilo que afligia em palavras, surge, inquestionavelmente, um alívio, a sensação de que não se está sozinho em sua angústia, que isso existe mesmo, que outras pessoas já passaram por isso antes e que é possível falar sobre isso com outras pessoas, pesquisar, conhecer mais e encontrar uma maneira de lidar com a questão. A possibilidade de nomear é extremamente calmante e terapêutica, mas, mais do que isso, ela é humanizadora na medida em que permite o exercício de uma capacidade que só o ser humano possui: o fato de atribuir a determinado objeto real ou a determinada experiência um signo, uma representação. É por isso que Maria Zilda Cunha defende a importância de se incorporar uma visão semiótica $^{30}$ nos estudos das elaborações de nível simbólico e do pensamento lógico dedutivo. De acordo com a autora:

\footnotetext{
${ }^{30}$ A teoria peirceana, por exemplo, perscruta semioses - ou a dinâmica viva, evolutiva e multiplicadora que engendra processos criativos e intelectivos. Tal horizonte teórico leva-nos a valorar positivamente a multiplicidade e a diversidade crescentes como as formas artísticas vêm se apresentando, bem como a entender que desse modo estamos mais dispostos ao poder sensório, perturbador e também cognitivamente transformador da arte. Complementando esse raciocínio, parece-nos importante assinalar como a articulação entre as áreas do saber, como a psicologia do desenvolvimento, as ciências cognitivas, as ciências da computação e o estudo das vidas artificiais e da robótica motivaram relações outras aos estudos de ensino e aprendizado. Ao retomar a preocupação com fatores fundamentais da cognição humana em inteligências artificiais, acabam por entender ligações indissociáveis entre mente e corpo e
} 
Qualquer uma dessas abordagens teria a ganhar com uma teoria semiótica como a de Pierce, cujo grau de abrangência, abstração e generalização permite inter-relacionar conhecimentos, formas de representação icônicas, indiciais e simbólicas, sendo que estas últimas compreendem representações proposicionais e inferenciais, nas suas variedades abdutivas, dedutivas e indutivas (CUNHA, 2009, p. 23)

Além dessa busca por nomeação, acrescenta-se, ainda, a importância de encontrar, na escola e na vida contemporânea como um todo, um lugar e uma ocasião adequados para se tratar de tais questões. A falta de espaço e de tempo para tratar das questões que necessitam de nomeação talvez seja tão preocupante quanto a própria necessidade de nomeação. A escola perde imensamente no momento em que não oferece espaços propícios para a simbolização e retira a voz do aluno, que o cala em nome da aprendizagem, que quase nunca se concretiza, de um objeto de ensino ideal estático, recortado da realidade vivida pelos alunos. Ao se retirar a possibilidade de manifestação dos alunos acerca de suas vivências e emoções, de seus afetos e sonhos, de suas realizações verbais, traduções de suas elaborações mentais, abandona-se não apenas o aluno, mas toda a humanidade, egressa da experiência escolar, ao abismo da ausência de significação, ao abismo da desumanização.

É obvio que Petit (2013) trata de uma realidade na qual o pensamento se faz tão raro. O contato com o outro e/ou com obras literárias para a semeadura de novas palavras no solo fértil da mente humana para a frutificação de novas significações e novas simbolizações é cada vez mais difícil. Não apenas na escola, mas em toda a organização social contemporânea, o tempo para a leitura e para a reflexão é cada vez mais investido em tarefas rasas, sem um aprofundamento simbólico digno da ânsia humana por uma vida intensa. A mente se esvazia, atrofia e definha não sem antes suplicar por sua vida simbólica através das crises de angústia, de ansiedade, dos ataques de pânico e, através da depressão, tão frequente em nossos dias. Nossos jovens sinalizam esse perigo através de rebeldia, vandalismo, automutilação, tentativas de suicídio e, quando nada disso surte efeito, partem para um ato extremo como o atentado realizado contra a escola Raul Brasil, no município de Suzano, em treze de Março de 2019.

por afastar a certeza das concepções estritamente racionalistas. A razão engendra sensibilidades. Estas inevitavelmente engendram os processos intelectivos (CUNHA, 2017, p. 191). 
A distância existente entre o ser humano contemporâneo e sua capacidade de simbolização é tamanha que qualquer pequena investida nesse sentido surte efeitos importantes. Em seu registro, a aluna Antígona observa que, até mesmo alunos desinteressados, que já desistiram da vida escolar e se negam a realizar as suas tarefas, se interessaram e fizeram seus Diários:

Foi muito boa essa experiência, acho que os professores deviam sim passar isso para os alunos. Porque vi "pessoas desinteressadas" fazendo e gostando da atividade. Então acho que foi muito bom não só para nós, mas, para a professora também ${ }^{31}$. (informação verbal)

Não apenas para os alunos, mas a aluna Antígona observa e registra que, até mesmo para a professora a atividade foi positiva. Ela não especifica o aspecto sobre o qual a atividade foi boa para a professora, mas é possível que ao constatar o efeito terapêutico, a humanização em seus alunos, a professora tenha se alegrado, mesmo estando na atividade apenas como mediadora. É possível considerar que, além do alívio terapêutico, a humanização apresente também um caráter contagioso irresistível.

Assim, considera-se que, para a aluna Antígona, a atividade se mostrou bastante positiva, por ter proporcionado uma oportunidade de simbolização e, portanto, de humanização, pela constatação do interesse dos alunos envolvidos e pela observação, até mesmo, de aspectos positivos da atividade incidindo sobre a professora, que atuava na atividade apenas como mediadora.

- Diário de Leitura $\mathrm{N}^{\circ}$ 2, aluna Alice (Disponível no anexo B)

\section{Sobre a Leitura Livre}

De modo semelhante à Antígona, autora do Diário analisado anteriormente, a aluna Alice também realiza movimentos de identificação e de lembrança, no entanto, a identificação experimentada por Antígona diz respeito à semelhança observada entre um traço de personalidade do personagem Gigante e um traço de personalidade dela: ambos são ansiosos. Diferentemente, a identificação experimentada por Alice se dá por uma perspectiva narrativa, na medida em que tanto Gigante quanto ela passaram por "chacotas" dada determinada condição física: "No primeiro parágrafo eu me identifiquei

\footnotetext{
${ }^{31}$ Aluna Antígona, Diário de Leitura, Histórias de Convivência.
} 
com o Gigante, porque na minha infância, no fundamental I, eu sofria chacotas por ser baixinha e gordinha"32 (informação verbal).

Embora a identificação de Antígona se concretize pelo reconhecimento de traços de personalidade semelhantes e a identificação de Alice resulte da vivência de algo parecido, a identificação de Alice também atribui legitimação à sua realidade na medida em que alguém, que viveu algo semelhante ao que ela viveu, fora digno de representação literária. Através do registro de Alice, houve oportunidade para uma reflexão acerca da oposição entre o valor estereotipado, tão incisivamente afirmado pelo senso comum de que tudo o que aparece nos livros e nos meios de comunicação deve ser grandioso, ostensivo e/ou extremo, e a possibilidade e a sensibilidade implicadas na ocasião em que se passa a compreender a grandiosidade intensamente condensada em pequenos feitos, na consideração da vida cotidiana simples, semelhante à experiência de vida dos alunos.

Essa identificação narrativa, registrada por Alice, aparece seguida por um movimento rememorativo. Observe:

\begin{abstract}
Também me lembrei em determinado trecho da história que um fato muito parecido me ocorreu, eu estava com meus amigos brincando de vôlei e a bola caiu em um terreno e lá fui eu, sabichona, aventureira, pular o muro do terreno para salvar a bola que corria risco de vida, quando eu pulei o muro, cai e rasguei o joelho em um prego e achei uma boneca, estava suja e mal cuidada então peguei ela e a bola, despulei o muro e fui pra casa cuidar dela e ela está comigo até hoje ${ }^{33}$. (informação verbal)
\end{abstract}

O movimento de encontro com as memórias realizado por Alice é bem diverso do movimento realizado por Antígona para quem memórias e identificação apareceram de forma um pouco mais independente: Antígona teve as memórias de seu avô trazidas à tona por um único elemento da trama, o caminhãozinho de bombeiros, enquanto o processo de lembrança de Antígona resultou da observação de todo um enredo semelhante a algo já vivido. Essa fonte tão diversa para o desencadeamento dos processos de lembrança nos conduz, novamente, à já mencionada polissemia da leitura. Observe que leitores diferentes tendem a se fixar em elementos bem diversos da narrativa, atribuindo valores e significações totalmente diferentes àquilo que leem. Tal constatação evidencia a riqueza potencial dos encontros de partilha de experiências de

\footnotetext{
${ }^{32}$ Aluna Alice, Diário de Leitura, Leitura Livre.

${ }^{33}$ Aluna Alice, Diário de Leitura, Leitura Livre.
} 
leitura, de forma que uma narrativa determinada nunca é a mesma a olhos humanos diversos, cada leitor atribui um valor e um significado diferente, seja a um elemento mais pontual, seja a um trecho mais complexo do enredo. Essa diversificação de construções de sentido diante da leitura e a riqueza que se observa quando cada um coloca a sua elaboração foi notada pelos alunos envolvidos na intervenção pedagógica e foi recebida com grande alegria na medida em que eles notavam que, cada uma das elaborações apresentadas pelos colegas era uma elaboração possível de ser empreendida e, portanto, era legitimada pelo grupo.

A seguir, Alice apresenta uma elaboração acerca de sua experiência de leitura:

No decorrer da história quando o narrador descreve o objeto achado pelo Gigante eu realmente cheguei a pensar que se tratava de uma arma, fiquei pensando "como ele poderia achar tal objeto tão magnífico". Achando o Gigante um garoto responsável, pensei que ele daria tal objeto a um adulto, mas ele não fez isso. Quando ele chega em casa depois de sair da escola, pegando o misterioso objeto e aproximando do olho para ver o que tinha dentro do cano com o dedo no gatilho fiquei em total pânico, então, para piorar tudo, o irmão dele chega e assusta ele fazendo o mesmo apertar o gatilho quase que eu gritei em casa. KKKK. Mas fiquei aliviada de que saiu apenas água do reservatório do tão misterioso caminhão de bombeiro de brinquedo que Gigante achara. Depois de tudo, encarei o texto e ri de mim mesma por pensar em algo tão grave ${ }^{34}$. (informação verbal)

Esse trecho de Alice afirma a experiência de leitura como algo dotado de tamanho vigor, cuja vivência seria capaz de proporcionar emoções bastante extremas como o pânico, a gargalhada (representada pelo "KKKK") e o alívio. Novamente nos deparamos com a perejivânia vygotskyana, a intensidade de uma experiência intensamente significativa pela perspectiva emotiva. $\mathrm{O}$ reconhecimento da leitura como uma experiência independente de justificativas funcionalistas ou pedagógicas, o entendimento de que se lê por prazer, para viver uma experiência fruitiva, capaz de despertar emoções intensas é algo muito valioso que está se perdendo. Michèle Petit (2009) afirma que:

Outro dia escutei George Steiner dizer na televisão que, nos Estados Unidos, $80 \%$ das crianças não sabiam o que significava ler em silêncio: ou tinham um walkman no ouvido enquanto liam ou estavam próximas a uma televisão ligada sentindo constantemente seu brilho e seus ruídos. Essas crianças não conheciam essa experiência singular que é ler sozinho, em silêncio. (PETIT, 2009. p. 17. Grifo nosso.)

\footnotetext{
${ }^{34}$ Aluna Alice, Diário de Leitura, Leitura Livre.
} 
Ao mencionar a experiência de leitura como algo intenso, capaz de despertar emoções tais como o pânico e a gargalhada, a professora interrogou Alice acerca de como foi, para ela, vivenciar uma leitura tão intensa, se ela já havia experimentado isso antes, se ela costumava sentir emoções tão fortes sempre quando lia. Ao que Alice respondeu:

Foi difícil pra mim ler esse texto porque a senhora falou pra nós pra nós procurar um cantinho sossegado pra ler daí eu fui tentar encontrar esse sossego, mas não foi fácil não. Meu irmão tava no quarto, daí eu fui pra sala, logo, lá vem meu irmão e liga a televisão, daí eu voltei para o quarto, fechei a porta, talz, e veio minha mãe: "Lava aquela loucinha lá pra mim enquanto eu lavo a frente de casa". Fui lá, lavei a louça, voltei para o quarto daí eu pensei "agora eu vou conseguir ler". Nada. Lá vem minha mãe de novo: "Vai comprar pão na padaria". Tipo, parece que se nós tá quieto lendo, parece que a gente não tá fazendo nada ${ }^{35}$. (informação verbal)

Observe que o depoimento de Alice revela que a experiência da leitura vivenciada por ela confirma a elaboração de Petit (2009) acerca da dificuldade de se reconhecer a leitura sozinho, em silêncio, como uma experiência significativa. Nas palavras da própria aluna "parece que se nós tá quieto lendo, parece que a gente não tá fazendo nada", é por isso que os jovens mencionados por George Steiner na citação de Petit não se contentam apenas com a leitura, eles o fazem com fones de ouvido ou diante da televisão ligada. A experiência de uma leitura intensa exige um ritmo, um espaço e um tempo diferenciados das condições exigidas pelas tarefas cotidianas, principalmente na contemporaneidade, cujos velozes processos de comunicação e produção invadem todas as esferas de experiência humana, de forma que vivenciar uma experiência intensa de leitura exige uma alteração de estados iniciais demasiada dificultosa, contra a qual o ritmo cotidiano estará sempre em constante interferência. Sobre essa alteração de ritmos entre a realidade cotidiana e a leitura intensa, as palavras de Daniel Pennac (1993) são significativas: "O tempo para ler é sempre um tempo roubado. (Tanto como o tempo para escrever, aliás, ou o tempo para amar). Roubado a quê? Digamos, à obrigação de viver”. (PENNAC, 1993. p. 118). Ainda acerca da experimentação de uma leitura tão intensa, ao ser interrogada sobre a capa de seu Diário, que retrata os personagens Alice e o Chapeleiro Maluco da obra Alice nos país das Maravilhas, a aluna respondeu:

\footnotetext{
${ }^{35}$ Aluna Alice em manifestação oral em sala de aula no encontro de Histórias de Leitura, 6 de novembro de 2018 .
} 
Então professora, sabe o que que é (risos), tenho vergonha de falar (risos), não então, é que a senhora disse que na capa a gente tinha que fazer uma imagem que representasse o que a gente tinha sentido mais forte na atividade, daí (risos) ah, então né, daí eu senti, tipo assim, como se eu fosse a Alice do País das Maravilhas, como se eu tivesse caído em um outro mundo através da leitura, e como se eu tivesse mesmo sendo o Gigante, na realidade do conto, em um outro mundo, o País das Maravilhas da leitura ${ }^{36}$. (informação verbal)

Mesmo constatando a laboriosa empreita necessária à experiência de uma leitura significativa, Alice consegue, ao final de seus esforços, descrever uma vivência bastante rica e, mais do que isso, ela consegue registrar a sua experiência em seu Diário e encontra a disposição necessária para falar sobre tal experiência, em sala de aula. Ela traz para a discussão proposta a sua dificuldade e a intensidade de uma experiência vivida diante de alguma insistência e obstinação. Ela pontua muito bem, com suas palavras de estudante de catorze anos, que a leitura implica determinado esforço para que se chegue a certa gratificação na medida em que exige uma suspensão do ritmo cotidiano em troca de uma experiência diante da qual o leitor não será mais o mesmo.

Em termos gerais, pode-se observar que os registros apresentados por Alice, em sua Leitura Livre, ratificam tanto o processo de identificação resultante da leitura como o processo de rememoração, conforme o mencionado por Antígona, no entanto, Antígona inicia um processo de identificação e de lembrança através de um único elemento e Alice o faz por uma perspectiva narrativa, por ter vivido algo semelhante. $\mathrm{O}$ processo de identificação e de rememoração registrados por Alice também evidenciam tanto a possibilidade de legitimação de uma identidade e de toda uma realidade através do registro artístico literário quanto a polissemia da leitura. Por fim, Alice termina seu registro de Leitura Livre pontuando a intensidade da leitura vivenciada por ela a ponto de ter experimentado emoções tão intensas quando o pânico e o riso. Tal observação de Alice é importante por fornecer oportunidade para a reflexão acerca da dificuldade de se conseguir espaço para a vivência de uma leitura que contrarie o ritmo cotidiano contemporâneo, além de evidenciar o quanto a leitura pode ser intensa quando o leitor se propõe a ir à busca do ritmo necessário à experiência de uma leitura significativa.

\footnotetext{
${ }^{36}$ Aluna Alice em manifestação oral em sala de aula no encontro de Histórias de Leitura, 6 de novembro de 2018.
} 
Sobre as Histórias de Leitura

Logo após o encontro de Histórias de Leitura, Alice fez o seguinte registro de suas impressões diante da partilha dos colegas:

\begin{abstract}
No encontro de histórias de leitura, o que mais me chamou a atenção foi... o relato da aluna Antígona, pois tive a capacidade de sentir os mesmos sentimentos que ela, a saudade de ter perdido alguém tão importante é a mesma culpa que eu carrego de não ter sido próxima para aproveitar o momento e a oportunidade de desfrutar de um carinho diferente, com a perda do meu padrinho percebi o quão trouxa fui de não me aproximar dele, não sentir seu abraço, não ouvir seus conselhos e suas histórias da sua infância e o decorrer da juventude dele, percebo hoje em dia o quanto isso me afetou e a culpa que sinto por isso é algo que nunca vou tirar de dentro de mim. Não tenho nenhuma boa lembrança igual a aluna Antígona e isso me abala muito. Mas mesmo depois de tudo eu sinto ele me guardando, me levantando quando eu caio. Até hoje isso dói dentro de mim e não tem nada nem ninguém que faça isso parar e sair de $\operatorname{mim}^{37}$. (informação verbal)
\end{abstract}

Observa-se, no breve relato de Alice, o quanto a partilha da colega foi importante. Como o já mencionado acerca da polissemia da leitura, até então, nada nos registros de Alice, apontavam para a lembrança de seu falecido padrinho, foi com a partilha de Antígona que Alice se colocou, mais do que em situação de identificação, mas em situação de empatia. Ela chega à lembrança de algo doloroso para ela a partir da exposição de uma situação semelhante, vivida pela colega, ela reconhece a dor do outro em si. Esse movimento empático é algo extremamente valioso, sobretudo no ambiente escolar, pois promove o encontro com o outro em nível subjetivo bastante profundo e significativo o que, de alguma forma, parece estreitar os laços afetivos entre os alunos envolvidos. Nas palavras de Dante Gallian, trata-se do já mencionado efeito estabelecimento da humanização através da abertura para si e para o outro, diante do qual nos deteremos um pouco mais agora.

Complementando e aprofundando a lógica do conhecimento do humano e do autoconhecimento que a leitura e discussão de grandes obras da literatura desencadeiam, a dinâmica do Lablei amplifica o processo, agregando a dimensão da alteridade dialógica determinada por uma estrutura grupal, coletiva. Neste contexto, o processo de revelação e descoberta do humano e de si mesmo se fundamenta, essencialmente, na descoberta do outro. Assim, para além dos conteúdos trazidos pela obra literária que se está discutindo, o participante se vê envolvido numa trama de conteúdos, não só conceituais, mas também afetivos e emocionais, que emergem das múltiplas leituras narrativas que se compartilham na confluência das experiências de vida que se encontram. Desta forma, os efeitos do LabLei em seus

\footnotetext{
${ }^{37}$ Aluna Alice, Diário de Leitura, Histórias de Leitura.
} 
participantes comprovam que para além do encontro do humano através da literatura, o encontro consigo mesmo se potencializa e se amplifica através do encontro com o outro no processo de compartilhamento de leituras, de afetos, de conhecimentos, de descobertas. (GALLIAN, 2017. p. $186-187)$

É importante que esse encontro com o outro, norteado pelo reconhecimento e valorização da esfera subjetiva e afetiva, tenham espaço no ambiente escolar, primeiro por reconhecer a importância de tais aspectos na formação de sujeitos mais humanos, alternos (indivíduo dotado de alteridade), empáticos, éticos e de inteligência emocional mais apurada ${ }^{38}$. Segundo por reconhecer a contemporaneidade e, por consequência, a escola como realidades de estremada frieza subjetiva e emocional, diante da qual, caracteres humanos e coletivos são, cada vez mais, negligenciados em nome da formação do "indivíduo autônomo", crítico de seu tempo, que sabe apontar incongruências, mas que não enxerga que tais incongruências resultam de mecanismos maiores. Tal imediatismo crítico conduz o corpo discente rumo a uma formação cada vez mais individualista, diante da qual a coletividade, a convivência entre semelhantes e diferentes, se perde diante da ilusão de uma ineficácia e de uma impossibilidade fatais, alimentando as fontes silenciosas da intolerância, do ódio e da violência.

É imperativa a necessidade de tratar dessas questões subjetivas e emotivas, dada a falta de espaço conferida a tais questões na realidade contemporânea. O próprio Diário de Antígona, analisado anteriormente, já aponta a dificuldade de se encontrar ocasião para se tratar de determinadas questões: “o assunto do 'meu avô', é muito delicado lá em casa, então prefiro nem tocar no assunto. Mas na sala eu consegui me abrir e falar tudo o que tinha vontade" 39 .

No entanto, ao se buscar providenciar espaço para a consideração e a reflexão acerca da subjetividade, é comum aparecer críticas, extremamente contundentes, que alertam para a falta de um profissional com a formação adequada para tanto e os perigos de se tocar em certos assuntos que possam desencadear uma reação mais exaltada e até mesmo violenta e perigosa. Ao se deparar com esse tipo de crítica, Gallian respondeu da seguinte forma:

Por outro lado, alguns pesquisadores já me questionaram sobre os perigos de uma reação emocional mais exacerbada que pode ocorrer nesses encontros. É curioso, entretanto, que em mais de 13 anos de experiências, nos mais

\footnotetext{
${ }^{38}$ Sobre esse assunto, veja DE PAULA, UBI SOLITUDINEM FACIUNT, PACEM APPELLANT: sobre a política, a escola, a crise retórica e a literatura, 2018.

${ }^{39}$ Aluna Antígona, Diário de Leitura, Histórias de Convivência
} 
diversos cenários, nunca nos deparamos com um caso dessa natureza. Muito provavelmente alguma característica própria da metodologia do Laboratório acabe determinando uma força de contenção ou de defesa a tais fenômenos. Tal tese merece ainda ser investigada. (GALLIAN, 2017. p. 137).

Além do mais, em nenhum momento ao longo da intervenção pedagógica, houve insistência alguma para que os alunos se pronunciassem, muito pelo contrário, houve uma série de intervenções da professora para que os alunos fossem um pouco mais breves, para que todos tivessem a oportunidade de falar. A necessidade, por parte dos alunos, de falar e de ser ouvido é incisiva e emergencial, de forma que a atmosfera da intervenção nada tem de uma atividade constrangedora, que exponha o aluno de alguma forma, eles estão sempre muito ansiosos por se colocarem, por sentirem que são ouvidos e, o mais interessante, por ouvir o outro. É como se, no medo de se cometer alguma falta ao se tratar de questões emocionais e subjetivas, incorremos em outra, imensamente mais grave: o fato de não nutrirmos, entre crianças e jovens, o amadurecimento da elaboração emotiva-afetiva, da maturidade subjetiva. É a partir dessa falta que surge um imediatismo e um fatalismo desmedidos, diante do qual qualquer obstáculo se converte em uma barreira intransponível, não há mais nada a se fazer, o que, por sua vez, vai conduzir o jovem ao comportamento destrutivo. A afirmação de que há certo risco no empreendimento de reflexão subjetivo-emotiva é verdadeira e, como tal, deve ser considerada, no entanto, é muito maior o risco da apatia, do abandono de nossas crianças e jovens à frieza de um mundo no qual seus sentimentos e suas elaborações existenciais são negligenciados ou mesmo desconsiderados.

Assim, os registros de Alice evidenciaram o quanto a atividade realizada foi importante por ter proporcionado humanização através da abertura para si e para o outro, pelos processos desencadeados em Alice em sua exposição ao discurso de Antígona. Mais do que isso, os registros de Alice lançaram bases para a reflexão sobre a instituição escolar como ambiente de frieza subjetiva e emocional, onde as esferas de realização humana e coletiva são negligenciadas em nome da formação do "indivíduo autônomo", crítico de seu tempo, mas de um imediatismo crítico ingênuo e fatalista, bases sobre as quais se desenvolvem, silenciosamente, o fatalismo, o individualismo, a intolerância, o ódio e a violência. 
Sobre o Itinerário de Discussão

Em seu Diário de Leitura, no trecho reservado ao Itinerário de Discussão, Alice registrou o seguinte:

\begin{abstract}
Eu achei esse tipo de aula muito produtiva pra mim, porque eu aprendi coisas que não pensava que ia aprender como sentir os sentimentos dos outros em mim mesma, não julgar o personagem principal por palavras de terceiros, já que o Gigante se mostra como um garoto responsável, que sabe se alegrar com poucas coisas, sabe ver o valor grandioso de coisas pequenas, é amoroso e admira o heroísmo de salvar vidas ${ }^{40}$. (informação verbal)
\end{abstract}

Novamente, a questão acerca do que se ensina na escola aparece na reflexão sobre o Diário de Alice. Observe que, ratificando a elaboração analítica acerca de uma escola demasiada conteudista, presa às prescrições curriculares, a aluna afirma ter se surpreendido positivamente ao encontrar, no espaço escolar, uma atividade voltada à questão emotivo-subjetiva. Retomando a reflexão acerca do perigo em lidar com assuntos que possam desencadear uma reação mais exaltada, o registro de Alice é bastante claro ao afirmar o caráter positivo que, a seu ver, a atividade apresentou.

Mais do que afirmar a produtividade de se trabalhar a esfera emotivo-subjetiva, Alice também menciona outro aspecto que, em sua concepção, foi importante no desenvolvimento da atividade. Em suas palavras, Alice observa que "[...] segundo o narrador, o Gigante era um garoto irresponsável, indisciplinado na escola. Mas ao fazermos um aprofundamento no texto vimos que não era totalmente verdade, era apenas ideias que o autor queria colocar na nossa cabeça" ${ }^{41}$. O que Alice observa, sobre o caráter parcial do narrador em relação ao personagem Gigante, aparece em habilidades previstas no Currículo do Estado de São Paulo (2010) tais como "Reconhecer, na leitura de textos ficcionais, elementos que indiquem o comportamento e as características principais das personagens" (2010, p. 49); "Reconhecer, no texto, indícios de intencionalidade do autor" e "Posicionar-se como agente de ações que contribuem para sua formação como leitor, escritor e ator em uma dada realidade" (2010, p. 51). Mesmo presentes no currículo, tais habilidades, raramente, são trabalhadas em sala de aula, dada a dificuldade do trato com o tema e a deficiência, por parte do Estado, no oferecimento de formação para o trabalho com as habilidades determinadas.

\footnotetext{
${ }^{40}$ Aluna Alice, Diário de Leitura, Itinerário de Discussão.

${ }^{41}$ Aluna Alice, Diário de Leitura, Itinerário de Discussão.
} 
Em seu registro sobre o Itinerário de Discussão, Alice trouxe questões como a positiva surpresa experimentada ao se deparar com uma atividade que considerou a esfera emotivo-subjetiva, o que foi ocasião para a retomada da reflexão sobre o perigo em lidar com assuntos que possam desencadear uma reação mais exaltada, e a oportunidade de entrar em contato com um processo de leitura mais profundo, no qual se evidenciou toda uma complexa construção de parcialidade por parte do narrador em relação ao personagem Gigante, uma habilidade que, mesmo sendo exigida no rol das habilidades curriculares, acaba, raramente, sendo trabalhada em sala de aula.

Sobre as Histórias de Convivência

Alice não realizou o registro referente a essa parte da atividade por ter faltado no encontro destinado à partilha das Histórias de Convivência.

- Diário de Leitura $\mathrm{N}^{\circ}$ 3, aluno Narciso (Disponível no anexo B)

Sobre a Leitura Livre

Em relação ao seu processo de Leitura Livre, o aluno Narciso afirmou o que se segue:

No começo do texto, pra mim, ele estava bem engraçado, um anão tentando pular o muro da escola. O texto estava parecendo de comédia. Na parte que o Gigante foi merendar, achei um pouco de sacanagem mas bem engraçado. Acho que nunca vi uma criança ficar tão feliz ao achar um brinquedo, até parece que ganhou um Playstation 4 Pro. Algumas partes é meio exagerado "impor respeito em qualquer moleque da sua idade", sério? Por causa de um brinquedo? Acho que esse garoto deve ter tido uma infância difícil para ele ficar feliz com um único brinquedo. Até parece eu querendo ganhar um Playstation 2, fiquei tão feliz que não queria tirar da caixa, mal consegui dormir ou comer. Algumas partes do texto eu pensei malícia, eu pensei que seria mais chocante, mas só foi uma história de um anão que achou um brinquedo. Texto normal. Nada de mais, bem tediante, só o começo que foi engraçado ${ }^{42}$. (informação verbal. Grifo nosso)

Primeiramente, observa-se que o aluno realiza uma leitura um tanto quanto fechada e contraditória, não há abertura para a construção de hipóteses que vão além daquilo que Narciso concebe através do seu repertório de valores, como o que acontece

\footnotetext{
${ }^{42}$ Aluno Narciso, Diário de Leitura, Histórias de Leitura.
} 
com Antígona em "me lembrei de quando meu irmão disse que preferia um caminhão de bombeiro do que um vídeo game"43 (informação verbal). Muito embora ele defenda que é um exagero um brinquedo impor respeito, mais adiante, ele afirma que ficou sem conseguir comer ou dormir por causa de um brinquedo. Ao não reconhecer a imposição de respeito advinda do caminhão de bombeiros, mas reconhecendo que ele próprio ficou em um estado alterado por um videogame, Narciso estabelece uma contradição justificada somente pelo fato de que, segundo a sua apreciação valorativa em relação aos brinquedos em questão, o Playstation é capaz de produzir uma forte alteração de ânimo, enquanto o caminhãozinho não pode impor respeito. Essa valoração é um tanto quanto parcial, muito embora ele se identifique com a alegria demonstrada por Gigante no momento em que ele ganhou o seu Playstation, ele não concebe o fato de que o caminhãozinho poderia ter produzido a mesma alegria no personagem.

Mais adiante, em seus registros, Narciso revela não ter notado duas ideias importantes presentes no texto. A primeira delas é a construção da confusão entre o caminhãozinho e uma arma. A segunda é o fato de Gigante não ser um portador de nanismo, uma condição genética, mas uma criança que ficou menor do que o esperado por complicações no momento de seu parto. A confusão entre o caminhão e a arma nem ao menos é mencionada e, a questão do nanismo é marcada no seguinte trecho: “[...] foi uma história de um anão que achou um brinquedo" 44 (informação verbal).

Ao final do seu registro, elaborando uma visão geral acerca de sua experiência de leitura, Narciso afirma ter se decepcionado com o texto, esperando algo, pelo seu ponto de vista, "mais chocante" 45 (informação verbal), no entanto, toda a sua experiência de leitura pôde, unicamente, o conduzir à leitura de um "Texto normal. Nada de mais, bem tediante, só o começo que foi engraçado" 46 (informação verbal).

Mesmo observando a questão da limitação na leitura realizada, é importante ressaltar que esse não é o momento para a realização de nenhuma crítica ou correção por parte do professor, entendido que o interesse do aluno em relação à participação na atividade está no fato de que ele detém e pode fazer uso do seu direito de voz, qualquer interferência no sentido de efetivar alguma correção pode interferir negativamente no

\footnotetext{
${ }^{43}$ Aluna Antígona, Diário de Leitura, Leitura Livre.

${ }^{44}$ Aluno Narciso, Diário de Leitura, Histórias de Leitura.

${ }^{45}$ Aluno Narciso, Diário de Leitura, Histórias de Leitura.

${ }^{46}$ Aluno Narciso, Diário de Leitura, Histórias de Leitura.
} 
processo, inibindo o aluno e prejudicando as manifestações dos alunos seguintes. Deve estar bastante evidente, aos alunos, que o momento de exposição é deles ${ }^{47}$.

O registro de Narciso, acerca de sua experiência de Leitura Livre, evidenciou certo fechamento valorativo, Narciso não concebe a importância do caminhãozinho, embora trace o paralelo em relação à sua experiência com o Playstation. Além dessa visão mais reduzida às próprias concepções, em sua leitura, Narciso não percebe que Gigante não é portador de nanismo e não menciona nada acerca do jogo efetuado entre o caminhãozinho de bombeiros e a arma. Narciso termina seu registro afirmando ter vivido uma experiência bem banal, sem maiores emoções. Mesmo observando tais ocorrências no registro de Narciso, é importante mencionar que o momento de Histórias de Leitura é um momento de manifestação dos alunos, não um momento de correção, intervenção e/ou crítica.

\title{
Sobre as Histórias de Leitura
}

A partir do momento em que Narciso participa das Histórias de Leitura, ouvindo o que os seus colegas tiveram a dizer acerca das experiências de leitura vivenciadas, Narciso muda completamente o tom e a orientação do registro apresentado no item Leitura Livre do seu Diário de Leitura. Observe:

\begin{abstract}
Depois de ouvir diversas histórias de leitura, eu percebi que li o texto de forma errada, mesmo um brinquedo tão simples deixou o Gigante feliz, mesmo sendo sem valor, ele via aquele caminhão de bombeiro com admiração. Depois de diversas histórias de leitura, percebi que um brinquedo pode fazer uma criança feliz, por mais simples que seja ${ }^{48}$. (informação verbal. Grifo nosso)
\end{abstract}

Ao ouvir os relatos de Histórias de Leitura dos colegas, Narciso realiza uma revisão de suas afirmações sobre a experiência de Leitura Livre vivenciada por ele e avalia a sua leitura como sendo uma "leitura errada". Essa mudança discursiva evidencia que Narciso, em seu registro de Histórias de Leitura acaba figurando, de

\footnotetext{
${ }^{47}$ Observe que, muito embora o presente estudo coloque uma interferência da professora no momento em que um aluno foi alvo das risadas do grupo (no capítulo Descrição das Etapas de Intervenção Pedagógica Desenvolvidas e Análise dos Resultados), trata-se de dois casos extremamente diferentes. A interferência apontada como indesejada é a interferência que vai contra a exposição das elaborações subjetivas dos alunos. Caso o responsável pela atividade note que algum dos alunos ficou em uma situação desconfortável, a interferência é absolutamente necessária. A ideia é que a atividade se dê em uma atmosfera confortável a todos, uma atmosfera humana, sem inibições ou constrangimentos.

${ }^{48}$ Aluno Narciso, Diário de Leitura, Histórias de Leitura.
} 
forma mais significativa, a elaboração de Lev Semyonovich Vygotsky, já mencionada anteriormente: a perejivânia.

Essa exposição da revisão/reavaliação/ressignificação, elaborada por Narciso, sinaliza algum entendimento no sentido de reconhecer o caminhão como possuidor de um valor além do julgamento estabelecido inicialmente. Aquilo que, primeiramente, se apresentou como uma leitura fechada em torno de uma única medida valorativa para as experiências e os objetos, converte-se, mesmo que de forma inicial, no sentido de sinalizar alguma compreensão acerca do fato de que as experiências e os objetos apresentam referenciais valorativos extremamente diversos, a depender do repertório prévio de experiências ao qual o sujeito fora submetido. Tal indício de mudança, mesmo que apenas no nível do discurso, e em estado inicial, é importante, pois representa a possibilidade de abertura para uma compreensão um pouco mais complexa do fato de que as experiências e as medidas valorativas de Narciso não são as medidas absolutas para a compreensão de todo o rol de experiências que a realidade humana pode vivenciar, o que é fundamental para a edificação de valores democráticos sobre bases sólidas, na medida em que se compreende e se passa a respeitar a diversidade e a pluralidade humana. Narciso passou por uma vivência, no sentido vygotskyano, na medida em que a sua experiência externa provocou um impacto afetivo capaz de conduzi-lo à reflexão e ressignificar o seu discurso anterior.

Observe como a transformação do discurso de Narciso evidencia o fato de que o ensino por meio de narrativas considera processos. Não se pode esperar que a realização de determinada intervenção pedagógica, baseada na leitura de uma narrativa, vá conduzir, invariavelmente, à apreensão de determinado objeto de ensino. Conforme o já observado no subtítulo Narrativa e Humanização, isso vai depender da experiência de vida que aquele leitor teve até se encontrar com a obra em questão. O que o ensino através da narrativa pode suscitar é o processo da narratividade, o processo de errar voltar atrás e reconsiderar determinado ato, assumindo as responsabilidades devidas, aprofundando a consciência em suas próprias concepções, imagens, valores, afetos etc.

A reflexão estabelecida na mudança do discurso de Narciso em torno do fato de que as possibilidades de realização humana, oferecidas pelo mundo, vão muito além da concepção que cada um tem da própria realidade é de importância capital, ainda, para a manutenção da democracia e a adesão ideológica às situações penosas das quais muitos ainda são vítimas, tais como a desigualdade social, a discriminação étnica, machista, xenofóbica, homofóbica, econômica etc. 
Toda essa vastíssima gama de possibilidades de reflexão e de mudança de discurso foi possibilitada através do encontro entre Narciso e a experiência de leitura de seus colegas de sala de aula, não através de uma coerção impositiva por parte da professora, como o apontado anteriormente. Esse encontro entre a manifestação de experiência de leitura de Narciso e a de seus colegas ratifica não apenas a humanização através da abertura para si e para o outro, de Dante Gallian, mas também ilustra o pensamento de Norvan Cyrulnik: “A ação de narrar (uma experiência) permite à pessoa se constituir em sujeito íntimo, e a narração convida a assumir seu lugar no mundo humano compartilhando sua história. O que é intimamente aceitável se associa ao socialmente compartilhável" (CYRULNIK, 2005, p. 98). Ao narrar a sua experiência de leitura para os colegas de sala e ao receber as narrativas destes, Narciso observa que a sua experiência de leitura não alcançou os níveis de representação e significação apresentados pelos outros, o que o faz pensar que a sua narrativa não seja "aceitável", para usar o termo de Cyrulnik. Assim, Narciso atribui ao seu relato a alcunha de "leitura errada" e elabora um novo discurso, um discurso que, a seu ver, estaria em consonância com o discurso de seus colegas, demonstrando ter compreendido o que, anteriormente, não havia notado.

Obviamente, isso não significa que Narciso tenha realmente mudado de atitude em relação à sua narrativa inicial, mas mostra que ele compreendeu uma perspectiva nova acerca da experiência de leitura. Isso se verifica de forma concreta no registro de Narciso pelo fato de que ele continua afirmando que o caminhãozinho é um brinquedo "sem valor". Demonstraria uma adesão um pouco mais sólida uma afirmação como "um brinquedo sem valor para mim”. No entanto, mesmo sem comprovar uma real adesão, a compreensão em questão é extremamente importante, primeiro porque toda a grande mudança tem seu início em uma nova compreensão e, segundo porque, a partir da compreensão de uma multiplicidade de perspectivas acerca de determinado aspecto, Narciso poderá refletir e fazer uma escolha um pouco mais consciente em relação ao rumo que tomará a formação de suas opiniões, ele não ficará abandonado à unilateralidade. Através da reconsideração de seu discurso, Narciso percebeu que ele pode observar situações dadas por perspectivas que vão muito além daquilo que ele tem como determinado e determinante, expandindo, como o já mencionado, horizontes de significação diante de fatalismos redutores.

Assim sendo, observou-se que a aproximação e abertura de Narciso em relação a seus colegas e a compreensão, por parte de Narciso, acerca de determinada distância 
entre as narrativas de experiência de leitura apresentadas, fez com que o discurso dele parecesse "inapropriado". Ao compreender as narrativas dos colegas, ao experimentar a perejivânia diante dessas narrativas e constatar a sua "inapropriação", Narciso alterou o seu discurso, registrando ideias em conformidade às ideias apresentadas por seus colegas. A grande importância presente nessa passagem não é a crença infundada no fato de que ele tenha, real e absolutamente, aderido ao discurso dos outros, a grande importância está no fato de que Narciso compreendeu, não por uma via coercitiva, mas por seu contato com os colegas de sala, uma perspectiva diferente da apresentada por ele inicialmente. A partir dessa compreensão, Narciso está livre para poder escolher entre seguir em frente com a alteração de discurso apresentada ou continuar com a postura inicial. Agora, ele está apto a edificar suas opiniões e escolhas de forma um pouco mais consciente, não sendo vítima de uma concepção unilateral.

Sobre o Itinerário de Discussão

Em relação ao Itinerário de Discussão, Narciso registra o seguinte:

Na primeira vez que li, não percebi que o autor estava querendo introduzir uma ideia na minha cabeça, para eu achar que era uma arma. Pelo julgamento, dava a entender que o garoto iria matar as pessoas com a suposta arma, mas todas as partes ruins foram mencionadas pelo autor, mas lendo com mais atenção, no texto há diversos fatores de que o garoto não iria fazer isso $^{49}$. (informação verbal)

Novamente, aparece uma alteração do discurso inicial, agora, por um novo aspecto: Narciso percebe que não havia, se quer, notado todo o arranjo textual no qual o autor fazia com que o leitor pensasse que o "brinquedo" encontrado por Gigante fosse uma arma. Assim como Narciso se abriu a uma nova possibilidade de concepção valorativa acerca do caminhãozinho, ele agora apresenta uma nova descoberta: o fato de que estava presente no texto algo importante que ele não havia percebido.

Ao constatar a polissemia da palavra "brinquedo" oscilando entre um brinquedo e uma arma, ele acompanha o raciocínio interpretativo apresentado pelos colegas, afirmando que a decisão acerca do significado da palavra "brinquedo" resulta de um julgamento realizado pelo leitor sobre o personagem Gigante. Mais do que observar a polissemia resultante do julgamento, Narciso também observa que esse julgamento não

\footnotetext{
${ }^{49}$ Aluno Narciso, Diário de Leitura, Itinerário de Discussão.
} 
acontece por uma ação livre do leitor, ele é conduzido por uma série de orientações colocadas pelo narrador (quem ele chama de "autor") que, à luz de uma análise um pouco mais detalhada das ações do personagem, acaba se mostrando um tanto quanto parcial. Aquilo que, a princípio, foi descrito como um texto "bem tediante" 50 (informação verbal), através do contato com a experiência do outro, já se mostra como algo mais complexo e surpreendente. Está-se diante do fato de que "não podemos pensar em nós mesmos, senão pelos outros e para os outros, sob a condição desse acordo substancial que, através do coletivo, busca o universal e [...] distingue sonho de realidade, loucura individual da razão comum”. (HALBWACHS, 2008, p. 20). Há, em Narciso, não apenas uma abertura em relação à necessidade de reflexão um pouco mais madura e receptiva acerca de seus valores, mas também em relação aos seus esquemas de leitura, que se limitam a algo mais superficial.

Assim como na sua experiência de Histórias de Leitura, o Itinerário de Discussão de Narciso demonstra continuar a sua experiência de abertura mediada pela experiência dos outros colegas de classe. Mais do que ponderar acerca de uma tendência a considerar o outro pela sua própria valoração, Narciso também desperta para a possibilidade de experimentar uma estratégia de leitura um pouco mais madura e aprofundada.

Sobre as Histórias de Convivência

Na última parte de seu Diário de Leitura, Narciso finaliza seus registros com o seguinte balanço da atividade:

\begin{abstract}
Com essa atividade eu aprendi a ter um pouco mais de empatia. Em relação à sentimento, eu fiquei surpreso por um simples caminhão de bombeiro fazer o garoto tão feliz, sem empatia acabei achando um brinquedo bobo. Aprendi também a ler o texto com mais "profundidade", sem julgar apenas pelo que o narrador fala. ${ }^{51}$ (informação verbal)
\end{abstract}

O balanço feito por Narciso vem finalizar o seu Diário com a afirmação clara de que tanto o processo de abertura em relação à valoração quanto em relação às suas estratégias de leitura foram processos conscientes, ou seja, o próprio aluno pôde refletir e perceber que houve uma mudança considerável entre o seu estado inicial e o momento

\footnotetext{
${ }^{50}$ Aluno Narciso, Diário de Leitura, Histórias de Leitura.

${ }^{51}$ Aluno Narciso, Diário de Leitura, Histórias de Convivência.
} 
após a intervenção. Mais do que refletir e perceber, o aluno consegue colocar em palavras e pontuar as suas aberturas através dos termos "empatia" e "profundidade".

Se o Narciso mitológico se perdeu em um mergulho no próprio ego, o aluno Narciso mergulhou "profundamente" na experiência de leitura do outro e, em um movimento "empático", terminou revestindo-se de maior consciência, liberdade perceptiva, reflexiva e volitiva, ressignificando sua limitação em abertura e liberdade.

Diário de Leitura No 4, aluno Epimeteu (Disponível no anexo B)

\section{Sobre a Leitura Livre}

Antes de iniciar uma análise mais detida sobre o registro de Epimeteu, propriamente, é importante ressaltar que Epimeteu é um aluno que, por muito tempo, não realizou nenhuma das tarefas propostas pela escola, seja uma lição em sala de aula, um trabalho para ser feito em casa ou mesmo um trabalho em grupo. Ele é um dos alunos aos quais Antígona faz referência em seus registros quando diz "[...] vi 'pessoas desinteressadas' fazendo e gostando da atividade" 52 (informação verbal).

Epimeteu se mostra bastante ativo nas aulas de educação física e no intervalo, situações nas quais ele, de alguma forma, se sente o centro das atenções. Como a escrita não é uma esfera de atuação na qual ele se sinta atraente ao olhar do outro, ele se omite. O interessante foi observar que, mesmo com toda a sua dificuldade, ele se propôs à realização da tarefa, manifestando sua elaboração em torno da experiência de leitura vivida. A leitura do conto no perfazer da atividade proporcionou o ânimo e a sensibilização necessários para romper a barreira da dificuldade com a escrita. Como o observado no item Narrativas e Humanização, do presente estudo, na perejivânia, a sensibilização de um leitor diante da obra lida, o impacto afetivo na interação apreciador e objeto artístico, é o que conduz o leitor à reflexão. Se a obra não sensibiliza o seu leitor, ele dificilmente terá o impulso reflexivo sobre o que leu, daí a importância de se considerar o tempo de cada um, para que a leitura amadureça dentro de sua concepção e o leve à reflexão. De acordo com Cunha:

O tempo, nesse caso, é um tempo mais longo, uma vez que a própria natureza do objeto sob mira o requer. Essa atividade, que é comumente chamada de

\footnotetext{
${ }^{52}$ Aluna Antígona, Diário de Leitura, Histórias de Convivência.
} 
apreciar a arte ou fruir o que ela oferece, exige, então, que se constitua outra temporalidade. $\mathrm{O}$ tempo abreviado de perceber um objeto qualquer tal como ocorre continuamente no cotidiano não é suficiente para a compreensão do sentido de um produto de atividade artística. Em outras palavras, o objeto estético determina o tempo. (CUNHA, 2009. p. 34 - 35.)

É necessário que a narrativa proposta provoque um desequilíbrio, um incômodo, através do qual se seguirá em busca de um rearranjo, na tentativa de se estabelecer o equilíbrio, um equilíbrio revisitado, dada a modificação resultante do reajuste, do rearranjo estabelecido. Nunca se é o mesmo após a sensibilização e o aprendizado. É importante observar que essa disposição em busca do reequilíbrio demanda tempo.

Além da questão da sensibilização, o ânimo para a busca de um restabelecimento e o tempo demandado por tal processo, observa-se, ainda, que o fato de Epimeteu ter realizado seus registros no Diário e ter participado da atividade foi algo como um processo de empoderamento que o fez se apropriar da escrita. De acordo com Claude Lévi-Strauss, no capítulo Lição de leitura de Tristes trópicos:

[...] os Nambiquara não sabem escrever; mas tampouco desenham, com exceção de alguns pontilhados e ziguezagues nas suas cuias. Porém, da mesma maneira como agi com os Cadiueu, distribuí folhas de papel e lápis com os quais, de início, nada fizeram; depois, certo dia vi-os muito atarefados em traçar no papel linhas horizontais onduladas. [...] Para a maioria, o esforço parava por aí; mas o chefe do bando enxergava mais longe. Era provável que só ele tivesse compreendido a função da escrita [...]. Ora, mal ele reunira todo o seu pessoal, tirou de um cesto um papel coberto de linhas tortuosas que fingiu ler e nas quais procurava, com uma indecisão afetada, a lista dos objetos que eu deveria dar em troca dos presentes oferecidos [...]. Que esperava ele? Enganar a si mesmo, talvez; mais, porém, surpreender seus companheiros, convencê-los de que tinha participado na escolha das mercadorias, que obtivera a aliança com o branco e que partilhava de seus segredos". (LÉVI-STRAUSS, 2004. p.280. Grifo nosso.)

Do mesmo modo que a realização da escrita para o chefe Nambiquara representou a manutenção de sua posição diante do "seu pessoal", Epimeteu, talvez pela primeira vez, tenha se sentido capaz de produzir um registro escrito e uma participação oral, ao seu ver, dignos do lugar de destaque almejado por ele. Epimeteu tinha uma reflexão desenvolvida atrelada a um sentimento e um aprendizado sobre os quais ele queria se manifestar. Esse desejo de manifestação o moveu além das limitações impostas por sua dificuldade, ele realizou os registros e se pronunciou diante dos colegas nos encontros de partilha de experiência de leitura de forma compenetrada e alegre. Assim como o chefe Nambiquara, Epimeteu surpreende seus companheiros, convencendo-os de que, por mais que ele escreva com dificuldade, ele é perfeitamente capaz de realizar a tarefa 
proposta e mais: ele oferece uma reflexão sobre seu aprendizado que garante a ele o reconhecimento dos outros acerca do fato de que ele acrescenta elementos importantes à reflexão do grupo.

Ao considerar esse mesmo movimento de empoderamento através da realização da narrativa falada e/ou escrita, Fabiana Carelli defende a premissa de que é preciso estudar:

[...] as diferentes auras de poder que circundam e/ou não circundam oralidade e escrita. No limite, o perigo de não perceber esses fenômenos está na constituição de uma fala poderosa e ininterrupta que cala definitivamente aqueles que se acreditam (ou são creditados como) incapazes dela. Nesse caso, não ouvir o doente na especificidade de suas narrativas pode, sim, levar à morte - "desenlace" que, como menciona Foucault na epígrafe deste texto, cerra para sempre a boca de quem conta. Um silêncio próprio dos "inocentes" (CARELLI, 2013. p. 679)

Carelli se refere, especificamente, às narrativas em ambiente hospitalar, entre médico e paciente, porém, é possível considerar essa mesma relação de poder no ambiente escolar, entre professor e aluno. O perigo de se desconsiderar a importância de manifestação, de realização de voz de um aluno, pode, por um lado, conduzir esse aluno em um processo de revolta (bastante oportuno, diga-se de passagem) que o leva a sustentar uma postura inadequada, exprimindo, mesmo que de forma inconsciente, a sua insatisfação em relação à instituição escolar como um todo, uma instituição que não o considera e, portanto, não é digna de o ensinar. Por outro lado, e de forma cada vez mais frequente, alunos deixam essa revolta manifesta de lado para vivenciarem um sentimento silencioso e intenso de nulidade, uma morte simbólica que, cada vez mais, atraem crianças em idade escolar para atos extremos como a violência explícita contra si, no caso das automutilações e do suicídio, e contra o outro, no caso dos atentados. A desconsideração do exercício de voz de um aluno pode não conduzir à imediata morte física, mas a uma morte simbólica, à morte da vontade, à nulidade do sujeito que, por sua vez, pode culminar na morte física.

Além desse empoderamento, Epimeteu manifesta em seus registros uma energia bastante eufórica, como se ele tivesse descoberto que tem muito a dizer. É como se, ao contrário do Epimeteu mitológico, o Epimeteu escolar tivesse se deparado com a caixa de Pandora aberta e, de dentro desta, saíssem apenas coisas impressionantemente importantes e belas, diante das quais Epimeteu se vê surpreso e confuso. Essa ansiedade, aliada à sua dificuldade em escrita, produzem um registro um tanto quanto 
"desordenado", no entanto, não se trata de uma desordem gratuita, trata-se da manifestação de uma grande energia ansiosa e eufórica. Observe o trecho a seguir:

\begin{abstract}
Nossa eu no começo eu achei que ia entender mas eu não entendi muito mais no final eu fiquei muito surpreso porque o menino tava muito ansioso para brincar com o brinquedo novo eu achei que o brinquedo do menino era uma arma mais eu fiquei muito emocionado quando eu li a parte que o menino tava com o brinquedo e o dedo no gatilho eu achei que era uma arma mais era uma mangueira do carro de bombeiro daí essa hora eu fiquei muito confuso e eu não entendi o começo mais eu vou falar o que eu senti no começo eu senti uma curiosidade mais quando eu li essa frase (quando soube que ia passar a estudar de manhã na escola) daí nessa frase eu fiquei muito contente porque eu também fico contente de estudar de manhã na escola e eu fiquei lembrando quando eu era mais menor eu tinha achado um brinquedo e eu gostava tanto do meu brinquedo que eu levei ele pra escola e eu não tava prestando atenção na aula daí o professor viu e pegou nessa hora eu chorei muito depois eu fui entender o lado ruim e o bom o bom é prestar atenção na aula e no intervalo eu brincar com o meu brinquedo novo e o meu lado ruim é não ter dado atenção pro professor e ter se entertido com o brinquedo e eu fiquei confuso quando eu li no começo e eu não consegui entender quando eu li uma vez por isso eu li mais uma vez foi aí que eu entendi e eu ia conseguir fazer mais um pouco e sempre que eu achar um brinquedo eu vou lembrar o que o texto tava falando de um menino que tinha uma brinquedo e que o seu apelido era Gigante porque seus amigos faziam bulem com ele..$^{53}$ (informação verbal).
\end{abstract}

A energia e a euforia que pulsam no registro de Epimeteu são tão notáveis que a primeira palavra do registro é a interjeição "Nossa".

Após essa primeira manifestação energética, Epimeteu segue descrevendo suas impressões de leitura pelo início da experiência. Ao contrário de Narciso, que mantém uma leitura bastante limitada, dado o seu fechamento valorativo, Epimeteu admite que não entendeu. Essa dificuldade de leitura manifesta por Epimeteu não representou a ele um obstáculo para a conclusão da leitura, ele segue com seus esforços até o final e, no final, ele demonstra ter compreendido mais do que Narciso, ao ter notado o arranjo léxico-semântico do autor para produzir a expectativa de que o "brinquedo" encontrado por Gigante era uma arma.

Além de ter compreendido o jogo entre "brinquedo" e "arma", Epimeteu demonstra, assim como Alice, ter vivenciado uma experiência bastante intensa de leitura, expressa pelas palavras "surpreso", "emocionado", "confuso", "curiosidade" e "contente".

Após elucidar a intensidade de sua experiência de leitura, Epimeteu volta ao começo de sua experiência, afirmando que vai dizer o que sentiu no começo, no entanto

\footnotetext{
${ }^{53}$ Aluno Epimeteu, Diário de Leitura, Leitura Livre.
} 
o relato dele não segue no sentido de manifestar uma emoção ou um sentimento, mas uma identificação e uma lembrança. Quanto à identificação com o fato de que Gigante iria estudar pela manhã, ele afirma apenas se sentir contente e segue com o relato da lembrança, na qual ele também achou um brinquedo. Após o relato da lembrança, Epimeteu realiza uma avaliação, retirando dessa avaliação um aprendizado: ter levado o brinquedo para a escola teve um lado bom e um lado ruim.

Depois dessa elaboração reflexiva e do seu aprendizado, Epimeteu revela ainda não ter entendido o início do texto e que, portanto, voltou ao começo, realizando mais uma leitura. Com a segunda leitura, Epimeteu afirma ter entendido, porém, ele não relata qual foi a sua dificuldade, apenas diz que vai se lembrar do texto e do personagem que achou um brinquedo e que sofria bullying.

Muito embora se observe certa ordem cronológica no registro da experiência de leitura, essa ordem não se faz contínua através das escolhas feitas no momento da escrita. Há algumas considerações importantes a serem feitas em relação ao uso inapropriado de certas palavras, à organização do texto e à ideia do bullying que, embora mencionada ao final, não foi trabalhada ao longo do texto. No entanto, este não é o momento para correções, qualquer interferência coercitiva poderia ir contra importantes construções às quais Epimeteu deu início com a atividade como: o processo de empoderamento da escrita, a abertura para a experiência de leitura e a insistência no desejo de compreender o texto.

Sobre as Histórias de Leitura

Em seu Diário, Epimeteu faz o seguinte registro, em relação à sua experiência nas Histórias de Leitura:

Na história de leitura eu fiquei triste porque o menino sofria bulem por que ele era o menor da sua turma por isso, eu fiquei muito triste e eu achei que o brinquedo do menino era uma arma e eu também achei que ele ia se matar porque ele sofria bulem, e também porque no texto fala que o menino tava com o dedo no gatilho. ${ }^{54}$ (informação verbal)

No registro sobre as Histórias de Leitura, Epimeteu restringe-se a realização de algumas notas referentes à sua própria participação oral. Epimeteu foi o primeiro que colocou em consideração a questão do bullying. Muito embora, o aluno não tenha

\footnotetext{
${ }^{54}$ Aluno Epimeteu, Diário de Leitura, Histórias de Leitura.
} 
trabalhado a questão do bullying no seu registro de Leitura Livre, muito embora ele houvesse realizado apenas uma breve menção ao final de sua elaboração textual, ele retoma a questão pela perspectiva narrativo-afetiva, em sua participação oral, no encontro de Histórias de Leitura. Epimeteu compartilha uma vivência sua, na qual ele é o autor da ação agressiva do bullying.

Ao unir a sua vivência com a perspectiva apresentada no conto, Epimeteu compreende seu erro e arrepende-se, manifestando compreensão, empatia e compaixão em relação ao personagem Gigante. Mais do que experimentar essa via de aprendizado, ao compartilhar o seu aprendizado com os colegas da sala por uma perspectiva narrativa, Epimeteu proporciona a experiência afetiva impactante, força motriz da reflexão e ressignificação, a seus colegas, proliferando as possibilidades de ressignificação de cada um dos envolvidos na atividade.

Como o visto, Epimeteu descreve a ocasião e a intensidade de seu arrependimento de maneira bastante comovente, porém, quando ele retorna para a casa e vai fazer os registros referentes à aula de Histórias de Leitura, ele não consegue transferir para o papel a riqueza de sua colocação oral. $\mathrm{Na}$ aula seguinte, a professora, ciente da dificuldade de Epimeteu com a escrita, pediu para ver o registro dele acerca das Histórias de Leitura. Ao ver o registro, a professora o questionou, afirmando que ele havia contribuído oralmente com as Histórias de Leitura de forma brilhante e que não havia escrito muito sobre a sua participação. Diante dessa observação da professora, Epimeteu responde:

Então, eu até lembrei que eu tinha falado bastante coisa, mas não sei... é difícil, tipo, às vezes, eu sei que eu tenho uns bagulho da hora pra falar, eu sinto umas coisas assim tipo uma revolta, não sei, mas escrever, por no papel, é difícil, não é igual falar. Quando eu penso, tá, eu penso, daí eu entendo, daí eu falo, beleza, às vezes eu sinto que eu consigo falar aquilo que eu queria, agora escrever... porque falar é uma coisa, escrever é outra. Eu não sei se dá pra entender o que eu tô falando agora. Aí, ta vendo? ${ }^{55}$ (informação verbal)

O relato de Epimeteu acerca de sua dificuldade é importante por evidenciar a percepção dicotômica apresentada por ele. Ele pontua bem a questão: se escrita e fala não são a mesma coisa, como transitar entre elas. É provável que o entendimento dicotômico dele resulte de uma visão na qual a variedade formal da língua, a norma culta, represente "a língua correta", a escrita, e as variedades não padrão, "a língua

\footnotetext{
${ }^{55}$ Aluno Epimeteu em resposta à observação da professora na aula de Itinerário de Discussão, 8 de novembro de 2018.
} 
incorreta", a fala. A concepção dicotômica da língua é bastante problemática no ambiente escolar, uma vez que essa concepção acaba por inibir o aluno que ainda não domina uma variedade um pouco mais próxima da variedade culta. É importante, em primeiro lugar, que o aluno se apodere da escrita utilizando a sua variedade e que, aos poucos, ele vá introduzindo elementos de uma elaboração um pouco mais culta, tendo como ferramenta de auxílio para essa aquisição a leitura. Eis aí a importância da atitude da professora ao ter liberado o uso das mais variadas linguagens na elaboração dos Diários, permitindo não apenas o uso de variedades não padrão, mas também modalidades de expressão distintas. Mesmo com essa liberdade, Epimeteu sente dificuldades, distanciando as modalidades de uso escrito e falado. Tentando sanar esse percalço revelado por Epimeteu, observa-se a importância da transição do ensino de língua entre os mais variados gêneros, para que se compreenda que fala e escrita não se apresentam em oposição, mas em um contínuo, indo desde realizações mais informais até as mais formais, seja na modalidade escrita, seja na modalidade falada. Epimeteu encontra-se em um estágio de empoderamento, no qual inicia por se perceber capaz de produzir um registro escrito. É importante que esse estágio de empoderamento, primeiramente, seja respeitado em seu tempo de maturação, depois, que seja bem nutrido por uma atividade leitora rica e apropriada, que não seja, apenas, um estágio restrito à coerção.

Além de revelar a dificuldade de trânsito entre o falado e o escrito, Epimeteu diz ter percebido o jogo edificado entre o "brinquedo" e a "arma", mas, o mais interessante está no fato de que Epimeteu não acredita que Gigante seria capaz de realizar nenhum mal contra os colegas que praticam bullying contra ele, suas considerações giram em torno da possibilidade de Gigante cometer suicídio. Epimeteu é o primeiro a considerar que o alvo da violência não era, necessariamente, o outro, mas o próprio protagonista da história. Novamente, Epimeteu traz uma contribuição reflexiva inédita diante do grupo, que foi recebida com grande seriedade pelos colegas e fertilizou as discussões.

Mesmo com toda a sua dificuldade, Epimeteu é um aluno sensível, reflexivo e receptivo à experiência de leitura que o texto oferece. É triste observar que um aluno capaz de trazer, para o seu grupo, considerações tão importantes tenha se calado durante tanto tempo, diante de atividades escolares prescritivas arbitrárias, sem um fundo reflexivo mais denso, capaz de cativá-lo à participação sincera e intensa. Um ponto muito forte da atividade, que fica evidente em Epimeteu, mas que também apareceu de forma intensa e frequente em outros alunos, ao longo de toda a intervenção, foi a 
satisfação diante do convite à atividade humana por excelência: a reflexão acerca de temas um pouco mais densos e abstratos. Observa-se assim que a capacidade de pensar, por mais que, de acordo com Michèle Petit (2009), mostre-se cada vez mais rara, é uma das vias mais importantes, se não a maior, para o encontro do homem consigo mesmo em sua condição, para a travessia dessa jornada nomeada como humanização.

\title{
Sobre o Itinerário de Discussão
}

Em seu Diário, o aluno Epimeteu, realizou o seguinte registro acerca de sua experiência no encontro destinado à realização do Itinerário de Discussão:

\begin{abstract}
Não devemos ter um prejulgamento e também não olhar pelo lado ruim das pessoas e nem pelas suas diferenças e eu senti com o menino a felicidade de ter um brinquedo novo e também me doi ver alguém sofrendo bulem ou falar em bulem eu já fiz uma vez com um dos meu melhores amigos eu falei uma coisa muito desagradável e depois disso ele nunca mais falou comigo e eu me arrependi muito e nunca mais vou fazer bulem com ninguém. ${ }^{56}$ (informação verbal)
\end{abstract}

Observe que Epimeteu inicia seu registro colocando a questão do prejulgamento, observando que ele taxou Gigante como um menino de conduta duvidável, no entanto, ao acompanhar o raciocínio da sala, pontuando as ações de Gigante ao longo da narrativa, o julgamento colocado não se sustenta. Indo um pouco além, Epimeteu afirma que não se deve "olhar pelo lado ruim das pessoas e nem pelas suas diferenças" (Aluno Epimeteu, Diário de Leitura, Itinerário de Discussão), buscando registrar uma das afirmações que apareceu ao longo do Itinerário: a relatividade e a arbitrariedade presente nos julgamentos, sobretudo quando o ser julgado é de classe social menos favorecida economicamente. Muito além da realidade socioeconômica, todo o ser vivente é dotado de qualidades e defeitos, certos grupos podem se identificar como sendo um pouco mais parecidos, mas, na totalidade, é da essência humana a diversidade e o erro, e talvez esteja justamente aí a maior riqueza humana: a capacidade de aprender com os erros e a vastidão da pluralidade entre grupos e seres, povos e culturas, tradições e civilizações, bases fundamentais para o desenvolvimento de valores democráticos de respeito ao outro e convivência pacífica. É esse aspecto da condição humana que Epimeteu, com suas palavras, busca expressar.

\footnotetext{
${ }^{56}$ Aluno Epimeteu, Diário de Leitura, Itinerário de Discussão.
} 
Epimeteu segue com a descrição de suas emoções despertadas através de um movimento de empatia: "[...] eu senti com o menino a felicidade de ter um brinquedo novo e também me doi ver alguém sofrendo bulem ou falar em bulem" 57 (informação verbal). Logo após essa elaboração, o aluno passa a narrar, finalmente de forma escrita, uma recordação sua, na qual ele afirma ter perdido um amigo muito querido por ter dito algo desagradável. Na realidade, esse relato ocorreu na participação oral de Epimeteu no momento das Histórias de Leitura, como o mencionado anteriormente, no entanto, ele não o registra na parte do Diário destinada às Histórias de Leitura, ele o faz posteriormente o que se deve, provavelmente, ao questionamento da professora acerca do fato. Tal ocorrência mostra a necessidade de um tempo maior que o aluno necessitou para a elaboração escrita. Por mais que ele tenha participado de forma oral, o registro escrito precisou de uma reflexão maior, que se concretizou em um maior espaço de tempo. Se o objetivo da atividade é a reflexão em torno da humanização, é importante notar que, para alguns alunos, o tempo destinado para a conclusão da atividade é um pouco mais extenso.

Em termos gerais, observa-se que o registro de Epimeteu acerca de sua participação no Itinerário de Discussão pontuou as questões do prejulgamento em relação aos erros e às diferenças, a capacidade de sentir no outro a felicidade de se ganhar um brinquedo novo, o sofrimento diante do bullying e, finalmente, o alerta sobre a necessidade maior que alguns alunos podem apresentar em relação ao tempo colocado para a elaboração dos registros escritos no Diário.

Sobre as Histórias de Convivência

Finalizando seu Diário de Leitura, Epimeteu realiza a seguinte avaliação:

Eu gostei de ler muito esse texto e eu aprendi que não deve fazer bulem com os outros e eu fiquei arrependido com tudo isso e eu aprendi a respeitar os outros na saúde ou na doença na riqueza ou na pobreza e eu achei esse texto muito massa e quando eu tiver um filho vo ensinar ele a respeitar os outros. ${ }^{58}$ (informação verbal)

Epimeteu afirma ter gostado da experiência de leitura. Ele retoma as questões do bullying e do respeito, mencionando, mais uma vez, o seu arrependimento. Na tentativa

\footnotetext{
${ }^{57}$ Aluno Epimeteu, Diário de Leitura, Itinerário de Discussão.

${ }^{58}$ Aluno Epimeteu, Diário de Leitura, Histórias de Convivência.
} 
de expressar a intensidade de sua experiência, inconscientemente, Epimeteu faz uma citação retirada dos votos matrimoniais, no entanto, o seu voto não se dirige a uma pessoa específica, mas aos "outros", todos os seus semelhantes, em suas afinidades e diferenças que, por sua condição humana, são dignos de respeito. Curiosamente, logo após citar os votos matrimoniais, ele menciona a possibilidade e/ou o seu desejo de ter um filho, através do qual Epimeteu perpetuará a mensagem do respeito.

Em uma avaliação bastante positiva da atividade, Epimeteu encerra seus registros, retomando o que de mais significativo fica para ele: o seu desejo de perpetuar a ideia do respeito ao próximo na continuação de sua descendência, através da geração e da educação de um filho. 


\section{Conclusão}

Primeiramente, retoma-se a pergunta inicial colocada para o presente estudo: como utilizar a narrativa para a ampliação dos horizontes interpretativo, criativo e fruitivo, alavancando as possibilidades de formação emocional, social e humana no ambiente escolar?

A análise da produção escrita dos alunos ao longo da intervenção pedagógica proposta evidenciou a possibilidade de se tratar de elementos referentes à vivência de um processo de humanização, através da leitura do conto pela metodologia LabLei adaptada à realidade escolar, nos seguintes termos:

Antígona foi ao encontro de suas lembranças, na medida em que sua reflexão, nomeação e ressignificação foram contra o esvaziamento da experiência. Sua identificação com o personagem a colocou em posição de enxergar-se através do outro e entender-se digna de representação artística literária. Ao expor a culpa que carrega por não ter dado espaço de convivência a seu "avô do coração" e, ao contrário da Antígona mitológica, não lhe ter acompanhado até a morte, sentiu a energia do acolhimento de seus colegas: a saudade se converteu em alegria ao perceber refletido em seus colegas a compreensão mágica da empatia.

Assim como no caso de Antígona, a identificação e rememoração registradas por Alice também evidenciaram tanto a possibilidade de legitimação de uma identidade através do registro artístico literário quanto a polissemia da leitura. Mas, em Alice, há algo mais: a intensidade da experiência de leitura vivenciada por ela foi tamanha, que ela pôde chegar ao ponto de ter vivido emoções tão intensas quando o pânico e o riso, o que trouxe para a reflexão a consideração da dificuldade de se conseguir espaço para a vivência de uma leitura que contrarie o ritmo cotidiano contemporâneo. Alice, em sua viagem pelo País das Maravilhas, vivenciou toda a intensidade de uma experiência de leitura fruitiva, capaz não apenas de fazê-la sentir emoções bastante fortes, mas também de proporcioná-la o aprendizado através da imersão em novas experiências e do transporte para outras realidades.

Narciso, em um movimento libertador, evidenciou a beleza e a intensidade da abertura valorativa, a recepção e compreensão de novas possibilidades de experiência humana e do processo de leitura através da perejivânia vygotskyana, rompendo com a visão limitada que o prendia aos próprios valores, diante do próprio reflexo, através das amarras da unilateralidade. 
Finalmente, Epimeteu trouxe para a composição a importância do tempo necessário à reflexão, a afirmação maior de que, em seu próprio momento, cada um pode trazer à tona contribuições inéditas e fundamentais, basta que se observe, honestamente, suas dificuldades e empodere-se de suas possibilidades de voz diante de todas as humanidades que fluem da Caixa de Pandora.

Com essa breve elucidação resultante da análise dos Diários de Leitura colhidos, observa-se que é possível promover, no ambiente escolar, uma oportunidade de ressignificação através da experiência da leitura, ou seja, de percepção significativa da vida vivida através da fruição literária, na contramão da exacerbada dinâmica de consumo, do ritmo acelerado e do vazio simbólico tão frequentemente observados na contemporaneidade. É possível proporcionar não apenas ao aluno, mas a todos os envolvidos no processo, principalmente ao professor, uma expansão dos horizontes reflexivos através da leitura por uma perspectiva artística-subjetiva partilhada, na qual inferências, avaliações, discussões, ampliação de repertório, reflexões e fruição - vias invariáveis de um sólido processo de humanização - são exploradas, vividas e compreendidas de modo significativo. O texto, neste sentido, torna-se um objeto literário singular, pois fica pleno em sua estrutura composicional plurissignificativa. A metodologia LabLei, sem dúvida, favorece o estabelecimento de um trabalho pautado sobre os elementos humanizadores observados, contribuindo não apenas para a concretização de um processo de humanização, mas, sobretudo, para a formação de um leitor mais sensível à riqueza de significação e à profundidade das possibilidades de verticalização do texto como objeto artístico. O objetivo inicialmente proposto como o desejo de alargar os horizontes humanísticos dos alunos envolvidos através da realização de uma intervenção pedagógica que, além de um mero exercício intelectual, promova a reflexão pelo contato com o texto não como objeto escolarizado, mas como objeto artístico, em torno de questões humanas em suas dimensões afetivas, intelectivas e volitivas, foi atingido.

Além da revisão do objetivo inicialmente proposto, observa-se também que não apenas os alunos que tiveram suas produções analisadas no presente estudo, mas a totalidade dos alunos envolvidos, avaliaram a intervenção como sendo bastante positiva tanto em termos de aprendizado como em termos de prazer simbólico e estético, na ocasião do contato com o registro literário artístico.

Mais do que o prazer simbólico-estético, a unanimidade dos alunos concordou com a afirmação de que há certo prazer em poder expor as suas reflexões e ouvir as 
reflexões do outro. A dinâmica da partilha foi definida como uma ocasião muito prazerosa, diante da qual muitos alunos ficaram ansiosos por poder manifestar suas elaborações reflexivas, por ouvir a elaboração reflexiva do outro e por poder receber uma nova perspectiva de leitura do conto, uma perspectiva ainda não explorada.

Se há prazer, satisfação e alegria em uma experiência de leitura sozinho, no desafio de construir uma significação resultante do contato com a obra a partir de um repertório de experiências prévias, esse prazer é, sem dúvida, intensificado com a partilha, com o encontro, com a construção simbólica do outro, em outras palavras, a experimentação estética se converte em algo muito mais intenso no encontro com o outro. O ser humano é, por definição, um ser sociável e nenhuma inovação tecnológica poderá substituir o calor da interação em presença, do aprender junto, do olhar correspondido, do sorriso compartilhado, do abraço apertado, da experiência narrativa da troca humana em sua simplicidade e seu calor. 


\section{Considerações Finais}

A desumanização assim como o vazio de significação e a paulatina perda da capacidade de narrar, de figurar um acontecimento em forma narrativa, todos estes, observados de forma cada vez mais incisiva na contemporaneidade, foram o norte que orientou o percurso reflexivo empreendido no presente estudo.

O exame das produções escritas dos alunos revela não apenas a efetiva possibilidade de tratamento de elementos relativos à humanização no ambiente escolar, mas também alerta para a urgente necessidade que os alunos têm em relação ao trato da questão. O estudo em torno de vias para um efetivo movimento de humanização escolar é demasiado imperativo e emergencial, na medida em que o cerne de nossa constituição enquanto seres humanos, a capacidade humana primeira de nomear, significar ou ainda simbolizar está sendo negligenciada, retirada de nós e deixando, em seu lugar, o vazio da insignificância, onde nada é importante, nada é relevante, nada é representativo, tudo se perde nas profundezas abissais de um mortal torpor blasé.

Mesmo, em um primeiro momento, embotados por tal onda tediosa, os alunos envolvidos na intervenção demonstraram grande entusiasmo na retomada de suas capacidades significativas tanto em termos de leitura, partilha, expressão e escuta, quanto em temos de produção escrita, nos Diários de Leitura, recuperando assim seus aspectos humanos fundamentais.

É importante observar que toda essa recuperação de aspectos humanos passa, invariavelmente, por um processo de evolução em relação à postura e à atitude dos alunos diante da leitura. Esta, de um objeto estático, passou a ser considerada, em sua verticalidade, como uma organização viva, rica em manifestações significativas, capaz de proporcionar, àquele que com ela trava contato, um universo de sensações, experimentações, reflexões, lembranças etc., tudo sempre colocado pelos próprios alunos envolvidos, de forma objetiva nas vivências oferecidas pela intervenção proposta.

Em relação às vivências, observa-se que o trato com elementos humanizadores acaba por proporcionar um encontro bastante significativo, forte e denso no sentido não apenas de perceber a si como um ser humano rico em experiências representativas do ponto de vista subjetivo pessoal, mas também, e, sobretudo, em reconhecer tal grandiosidade no outro, no colega que traz para a partilha aquilo que ele observou de mais marcante em seu processo reflexivo desencadeado pela leitura. A interação entre 
os alunos e a partilha são, sem dúvida, oportunidades únicas de expansão do universo de considerações e reflexões, contribuindo de forma singular para o enriquecimento e a pluridimensionalidade da intervenção realizada. Tudo isso sem mencionar a importância da descoberta de sentido suprimido de sua relevância através da ressignificação e a fascinante faceta anímica da narrativa sempre decorando, com traços artísticos mágicos, as vias de encontro entre aluno e leitura. Tanto a ressignificação quanto o aspecto anímico da narrativa foram conceitos cunhados no presente estudo, resultante da observação da interação subjetivo-emotiva dos alunos com o conto lido e entre si.

Até mesmo a professora, inserida na intervenção como mediadora de todo o processo, demonstra ter experimentado considerável aprimoramento e amadurecimento de sua capacidade de escuta, tanto em termos pedagógicos quanto em termos emotivos, subjetivos e humanos. A experiência de humanização contagia todos os seus implicados em um abraço caloroso e irresistível.

Além da importância de se manter sempre o foco sobre as implicações do trato com a humanização, registra-se a importância do estudo acerca da observação sobre uma possível "concorrência" e/ou da instalação e desenvolvimento de alguma "substituição" entre processos especulativos mais estáticos e o pensamento com base na narratividade. Faz-se necessária também uma elaboração mais aprofundada acerca do humano, da humanização e da desumanização, sobretudo, no apontamento de uma relação mais íntima entre os termos através das possibilidades oferecidas por uma visão semiótica, passando pelo aprimoramento humano com base em um refino das formas imaginárias. Finalmente, seria importante a consideração acerca do emprego de variadas linguagens no processo de humanização de todos os alunos presentes na sala: os alunos com dificuldade de escrita, os que se veem em situação de inclusão etc. além de uma reflexão em torno do fato de ser justamente a saúde a primeira instância social que, de forma prática, vai à busca da humanização.

Em termos gerais, a necessidade de estudos em torno da humanização tem, não apenas uma importância subjetiva pela possibilidade de aprender a observar a própria existência de forma mais significativa e, portanto, mais intensa e plena. Os estudos sobre a humanização apresentam um caráter social e um caráter político intrínsecos por orientar um processo reflexivo em torno de "quem se é" para, a partir daí, receber de forma democrática e pacífica o outro tanto em suas semelhanças como em suas diferenças. A humanização é um eixo de reflexão importante para a manutenção e a 
solidificação da paz entre seres semelhantes em suas diferenças e diferentes em suas semelhanças, entre seres, em essência, humanos. 


\section{Referências}

ADORNO, T. W. Notas de Literatura I. São Paulo: Editora 34, 2003.

AGAMBEN, G. Infância e história: destruição da experiência e origem da história. Trad. Henrique Burigo. Belo Horizonte: Editora UFMG, 2005.

AGAMBEN, G. O que é o contemporâneo? e outros ensaios. Trad. Vinícius Nicastro Honesko. Chapecó: Argos, Editora da UNOCHAPECÓ, 2009.

BRASIL. Base Nacional Comum Curricular. Brasília: MEC, 2017. Disponível em: http://basenacionalcomum.mec.gov.br/images/BNC C_20dez_site.pdf. Acesso em: 22 de dezembro de 2018.

BAKHTIN, M. Os gêneros do discurso. In: BAKHTIN, M. Estética da criação verbal. São. Paulo: Martins Fontes, 2003. p. 261-306.

BENJAMIN, W. O narrador: considerações sobre a obra de Nikolai Leskov. In: BENJAMIN, W. Obras escolhidas: magia e técnica, arte e política. São Paulo: Editora Brasiliense, 1994. p. 197-221.

BOSI, E. Memória e sociedade: lembrança de velhos. São Paulo: Companhia das Letras, 1994.

BRASIL. Lei de Diretrizes e Bases da Educação Nacional. Lei número 9394, 20 de dezembro de $1996 . \quad$ Disponível em: https://www2.senado.leg.br/bdsf/bitstream/handle/id/70320/65.pdf. Acesso em: 30 dez. 2019.

BRASIL. Base Nacional Comum Curricular (BNCC). Consulta Pública. Brasília, MEC/CONSED/UNDIME, 2015. Disponível em: http://basenacionalcomum.mec.gov.br/images/BNCC_EI_EF_110518_versaofinal_site. pdf Acesso em: 02 jul. 2020.

CANDIDO, A. O direito a literatura. In: Vários escritos. São Paulo: Duas cidades, 1995.

CANDIDO, Antonio. Literatura e Sociedade. 11 ed. - Rio de Janeiro: Ouro sobre Azul, 2010.

CARELLI, F. B. POMPILIO, C. E. O silêncio dos inocentes: por um estudo narrativo da prática médica. Interface: Comunicação, saúde e educação, Botucatu, v. 17, n. 46, p.677 - 681, jul./set. $2013 . \quad$ Disponível em: http://www.scielo.br/scielo.php?script=sci_arttext\&pid= S141432832013000300014\&lng=pt\&tlng=pt, consultado no dia 20 de setembro de 2019. Acesso em: 30 dez. 2019.

CARELLI, F. B. Eu sou um outro: narrativa literária como forma de conhecimento. Via Atlântica, n. 29, p. $17 \quad$ - 49, jun. 2016. Disponível em: https://www.revistas.usp.br/viaatlantica/article/view/119439. Acesso em: 30 dez. 2019. 
CIRÍACO, Rodrigo. Um novo brinquedo. In: ANACAONA, Ana (org.). Eu sou favela. São Paulo: Nós, 2015.

CUNHA, M. Z. Na tessitura dos signos contemporâneos. São Paulo: Editora Humanitas; Paulinas, 2009.

CUNHA, M. Z. Signos e suportes contemporâneos: notas sobre a literatura infantil e juvenil. In: DEBUS; E. BAZZO, J. BORTOLOTTO, N. (org.) Literatura Infantil e Juvenil pelas frestas do contemporâneo. Santa Catarina: Copiart, 2017, p 191.

CYRULNIK, B. O murmúrio dos fantasmas, São Paulo: Martins Fontes, 2005.

DELAMOTTE-LEGRAND, $\mathrm{O}$ que as narrativas infantis nos ensinam sobre a narrativa e o restante. In: FRANÇOIS F. Crianças e narrativas: maneiras de sentir, maneiras de dizer... Trad. Ana Lúcia Tinoco Cabral e Lélia Erbolato Melo. São Paulo: Humanitas, 2009. P. $11-44$.

FERREIRA, A. B. H. Miniaurélio: o minidicionário da língua portuguesa. $6^{\mathrm{a}}$ edição. Curitiba: Positivo, 2004.

FIORIN, J. L. Modos de organização do discurso: a narração, a descrição e a dissertação. In HUBNER et allii. Diário de classe 3. Língua Portuguesa. F.D.E. Secretaria da Educação do Estado de SP. S Paulo, 1994. p. 61 - 70.

GALliAN, D. M. A literatura como remédio: os clássicos e a saúde da alma. São Paulo: Martin Claret, 2017.

GAlliAN, D. M. PONDÉ, L. F. RUIZ, R. Humanização, Humanismos e Humanidades: problematizando conceitos e práticas no contexto da saúde no Brasil. Revista Internacional de Humanidades Médicas, v. 1, n. 1, 2012. Disponível em: https://journals.epistemopolis.org/hmedicas/article/view/1293/847 Acesso em: 30 dez. 2019.

GEERTZ, C. Obras e Vidas: o antropólogo como autor. Rio de Janeiro: Editora UFRJ, 2005 .

GULLAR, F. Na vertigem do dia. Rio de Janeiro: José Olympio, 2004.

HALBWACHS, M. A Memória Coletiva. São Paulo: Editora Centauro, 2008.

HOLLANDA, H. B. Literatura Marginal. Disponível em http://www.heloisabuarquedehollanda.com.br/ Acesso em: 11 ago. 2018.

HUMANIZA SUS - Política Nacional de Humanização PNH. Disponível em http://redehumanizasus.net/politica-nacional-de-humanizacao/ Acesso em: 07 ago. 2018.

JAEGER,W. O lugar dos gregos na história da educação. In: JAEGER,W. Paideia: a formação do homem grego. São Paulo: Martins Fontes, 1995. p. 03 - 20. 
JAEGER,W. Nobreza e Arete. In: JAEGER,W. Paideia: a formação do homem grego. São Paulo: Martins Fontes, 1995. p. 23 - 36.

JAEGER,W. Cultura e educação da nobreza homérica. In: JAEGER,W. Paideia: a formação do homem grego. São Paulo: Martins Fontes, 1995. p. 37 - 60.

JAEGER,W. Homero como educador. In: JAEGER,W. Paideia: a formação do homem grego. São Paulo: Martins Fontes, 1995. p. $61-84$.

JAEGER,W. Hesíodo e a vida no campo. In: JAEGER,W. Paideia: a formação do homem grego. São Paulo: Martins Fontes, 1995. p. 85 - 105.

LÉVI-STRAUSS, C. Tristes trópicos. Trad. Rosa Freire de Aguiar. São Paulo: Companhia das Letras, 2004.

LUKÁCS, G. A teoria do romance: um ensaio histórico-filosófico sobre as formas da grande épica. Trad. José Marcos Mariani de Macedo. São Paulo: Editora 34, 2000.

MAFFESOLI, M. Notas sobre a pós-modernidade: o lugar faz o elo. Rio de Janeiro: Atlântica Editora, 2004.

MAGALHÃES, A. A Bíblia como obra literária In: XI CONGRESSO INTERNACIONAL DA ABRALIC TESSITURAS INTERAÇÕES CONVERGÊNCIAS, 2008, São Paulo. Anais on-line. São Paulo: USP, 2008. Disponível em: http://www.abralic.org.br/eventos/cong2008/AnaisOnline/simposios/pdf /054/ANTONIO_MAGALHAES.pdf Acesso em 30 dez. 2019.

MEC - Diretrizes Curriculares dos Cursos de Graduação em Medicina. Parecer CNE/CES n ${ }^{\circ}$ 116/2014, aprovado em 3 de abril de 2014. Disponível em: http://portal.mec.gov.br/observatorio-da-educacao/323-secretarias-112877938/orgaosvinculados-82187207/12991-diretrizes-curriculares-cursos-de-graduacao. Acesso em 07 ago. 2018.

ORLANDI, E. P. A polissemia da noção de leitura. In: ORLANDI, E. P. Discurso e leitura. São Paulo, Editora Cortez, 2008.

PENNAC, D. Como um Romance. Rio de Janeiro: Rocco, 1993.

PETIT, M. A arte de ler ou como resistir à adversidade. Trad. Arthur Bueno e Camila Boldrini. São Paulo: Editora 34, 2010.

PETIT, M. Leitura de obras literárias e construção de si mesmo. In: PETIT, M. Leituras: do espaço íntimo ao espaço público. Trad. Celina Olga de Souza. São Paulo: Editora 34, 2013.

PETIT, M. Os jovens e a leitura. Trad. Celina Olga de Souza. São Paulo: Editora 34, 2009. 
PRANDO, F. C. Narrativa e resiliência: a invenção de si. Um estudo das narrativas produzidas a partir do jogo Enredo. 2019. 188 f. Dissertação (Mestrado em Estudos Comparados de Literaturas de Língua Portuguesa) - Faculdade de Filosofia, Letras e Ciências Humanas, Universidade de São Paulo, São Paulo, 2019.

RIOS, I. C. Caminhos da humanização na saúde: prática e reflexão. São Paulo: Aurea Editora. 2009.

ROUXEL, A. Práticas de leitura: quais rumos para favorecer a expressão do sujeito leitor? Trad. Neide Luzia de Rezende e Gabriela Rodella de Oliveira. Publicado em Cadernos de Pesquisa v. 42 n. 145 p. 272 - 283 jan./abr., 2012. Disponível em: http://www.scielo.br/pdf/cp/v42n145/15.pdf. Acesso em: 30 dez. 2019.

SANT’ANNA, M. A. D. O gênero da parábola. São Paulo: Ed. UNESP, 2010.

SÃO PAULO (Estado) Secretaria da Educação. Currículo do Estado de São Paulo: Linguagens, códigos e suas tecnologias - São Paulo: SEE, 2010.

SÃO PAULO. Secretaria da Educação. Currículo do Estado de São Paulo: Ciências Humanas e suas tecnologias. Disponível em: https://www.educacao.sp.gov.br/a2sitebox/arquivos/documentos/781.pdf. Acesso em 27 de nov. de 2019.

TOASSA, G. SOUZA, M. P. R. As vivências: questão de tradução, sentidos e fontes epistemológicas no legado de Vygotsky. Psicologia USP São Paulo, v. 21, n. 4, 2010. Disponível em: http://www.scielo.br/scielo.php?script=sci_arttext\&pid=S010365642010000400007. Acesso em: 30 dez. 2019.

TODOROV, T. Literatura em perigo. Trad. Caio Meira. São Paulo: Difel, 2009.

VYGOTSKY, L. S. A tragédia de Hamlet, Príncipe da Dinamarca. São Paulo: Martins Fontes, 1999.

VYGOTSKY, L. S. A questão do meio na pedologia. Trad. Márcia Pileggi Vinha. Psicologia USP São Paulo, v. 21, n.4, 2010. Disponível em: https://www.researchgate.net/publication/262518049_Quarta_aula_a_questao_do_meio _na_pedologia_Lev_Semionovich_Vigotski/link/03aa8b7c0cf2d6dfe89f6e15/download Acesso em: 02 jul. 2020.

WELLHAUSEN, J. Prolegomena to the History of Israel. Disponível em: http://www.gutenberg.org/cache/epub/4732/pg4732-images.html. Acesso em: $30 \mathrm{dez}$. 2019. 


\section{Anexos}

\section{Anexo A - Conto utilizado na intervenção}

\section{Um Novo Brinquedo}

\section{Rodrigo Ciríaco}

Gigante tem 11 anos, está no sexto ano do ensino fundamental. Quando soube que ia passar a estudar de manhã na sua escola, ficou preocupado. Afinal, apesar de estudar com o gêmeo, Gigante é bem diferente do irmão. Foi o segundo a nascer. E devido a algumas complicações no parto, ficou com um problema no seu desenvolvimento. Tem a estatura de um anão de jardim, ou um pouco menor, o que é motivo de zoeira, chacotas e muitas tretas na escola. Tretas porque ele não leva desaforo pra casa e, você sabe, os "grande" gostam de zoar com os pequenos. Na lei da selva é assim. E agora ia dividir território com a galera do Ensino Médio, uns caras bem maiores, folgados, alguns com maldade. Mas Gigante não se intimida, ele pensa: "tamanho não é documento."

Hoje ele estava feliz. Conseguiu enrolar a mãe antes dela sair para o trabalho e ficar "só" mais cinco minutinhos na cama. O irmão foi mais cedo, naquele junho de vento gelado e frio cortante. Ele ficou, atrasando o soneca do despertador do celular uma, duas, três vezes. O quanto pôde. Até que o telefone tocou.

- Hum?

- Eu não acredito que você ainda não levantou, Brayan.

- Hã?

- Brayan, levanta já dessa cama e vai pra escola.

Quando a mãe desligou o telefone brava, Gigante deu um pulo da cama que o chão quase tremeu. Olhou o relógio: eram cinco pra sete da matina, realmente estava atrasado. E não podia. Não podia atrasar, não tinha mais como faltar, a escola ia cortar o Bolsa Família, eles iam perder o leite, sua mãe iria endoidar. Levantou, colocou a primeira calça que achou, a camiseta amassada do dia anterior que estava sobre a cadeira, pegou o agasalho de moletom e o material sem conferir e saiu batendo porta, portão. Foi correndo, mochila nas costas. Quando já estava perto, pra encurtar caminho e não contornar o quarteirão, ajeitou o caixote de feira que estava encostado ao muro da 
escola, subiu. Não alcançava. Pulou, pulou, as unhas raspando sobre o muro. Um senhor que estava indo trabalhar olhou a cena, achou curioso.

- Quer ajuda, meu filho?

Gigante fez que sim com a cabeça. O senhor apoiou as costas sobre a parede, com as mãos entrelaçadas fez o calço, ele colocou o pé e num impulso subiu raspando a barriga, se apoiando. O outro lado parecia uma imensidão, o muro por dentro - e de cima - dando a impressão de ser mais alto do que de fora. $O$ chão lá embaixo, loooooonge. E meio verde, amarelando, de um mato seco. Gigante respirou fundo, contou até três, fechou os olhos e pulou, meio desajeitado e caindo.

- Au!

Uma coisa espetou bem na sua bunda, que ficou dolorida. Curioso como sempre, vasculhou, vasculhou embaixo daquele mato e: achou. Quando ele viu, não acreditou. Seus olhos faiscaram. Um brinquedo. Novo. Quer dizer, usado. Uma parte enferrujada, outra descascando. Um caninho longo, prateado. E um gatilho.

- Ah, muleque!

Gigante sorriu.

Olhou para os lados, não havia ninguém ali próximo. Muquiou o brinquedo dentro da mochila, debaixo dos cadernos, bem protegido e foi correndo pro portão da entrada das salas. Já eram quase sete e dez, a tia tava fechando. "Pérai, pérai, tia." Gigante entrou.

Na sala, chegou já suado. A roupa amarrotada, mas o rosto cheio de empolgação. Quando sentou, sacou logo caderno, caneta e lápis, ajeitou tudo em cima da carteira e colocou a mochila em cima do seu colo e ficou esperando a professora entrar. Os colegas na porta da sala chamando por ele:

- Ô DiMenor, chega aí pra vê o jogo novo que eu baixei.

- Vô nada.

- Chega aí, Mano. Da hora a parada.

- Vô não - insistiu. Os colegas estranharam, Gigante sempre curtia os corredores, era um dos últimos a entrar, depois de quase a professora e os inspetores o arrastarem. Mas lá estava ele, firme em seu lugar na sala.

- Aê, Gigante, tô te estranhando, hein. Que vontade de estudar - os colegas ainda zoaram.

E partiram. Ele fingiu que nem escutou. E ficou lá, fingindo que lia o texto que a professora passou, fingindo que tentava responder os exercícios, fingindo que prestava 
atenção nas três aulas que se seguiam mas o pensamento tava longe. Na verdade, bem próximo. Sobre o seu colo. Só pensava em como e quando ia usar o seu novo brinquedo.

No intervalo, como sempre - porque não teve jeito, a fome cantou mais alto - saiu correndo da sala e já foi pra fila da merenda. Mas não descuidou da mochila. Os moleques do segundo ano do Ensino Médio que adoravam sacanear os "merendeiros" depois de comprar seus lanches e refrigerantes na cantina passaram pela fila. Viram Gigante com a mochila nas costas. Riram do mochileiro na fila da merenda. Chamaram outros, juntou uma banquinha e um deles foi por trás, abaixou, passou os braços em torno de Gigante e o levantou. Ele batendo as pernas no ar, pedindo "para, para". Os rapazes deram uns dois giros com ele e soltaram. "E aí, Gigante. Vai acampar?”. Tiraram um sarro. Gigante ficou bem bravo com a provocação, bufando. Mas nem respondeu. Pensou no seu novo brinquedo na mochila e, no seu íntimo, sorriu.

Pouco antes do sinal da saída, começou a fingir que estava passando mal. Enjoado, com dor de cabeça. O professor de História olhou com suspeita para aquelas dores. Mas como não era médico e já tinha escutado que o garoto estava irreconhecivelmente comportado naquele dia nem se preocupou em deixa-lo sair um pouco mais cedo da sala e aguardar o sinal da turma no pátio. Gigante quase nem se aguentou de alegria assim que passou da porta da sala. Correu, encostou em um canto perto da saída, abriu a mochila. Sim, não era sonho. O brinquedo estava ali. Reluzente. Parecia até que brilhava. De impor respeito em qualquer moleque da sua idade, da sua quebrada. Ele se sentiu feliz como há tempos não ficava. Aquilo não era como catar uma pipa na rua, baixar um novo aplicativo. Aquilo era... Nossa, não tinha nem coragem de pensar alto. Vai que alguém ouve. Aquilo era chapado. Sinistro.

Quando o portão se abriu foi o primeiro a ganha a rua. Nem esperou o irmão, foi correndo pra casa. A mãe e o padrasto trabalhando, seu irmão lerdo como só ele era, voltando com a galera, tocando campainha das casas, bagunçando, ia demorar. Ele teria um tempo sozinho pra sacar finalmente o brinquedo da mochila e analisar com detalhes cada parte da sua nova aquisição. Chegou, tirou o tênis e o agasalho, deixou pelo caminho da cozinha, mochila debaixo do braço, foi para o quarto. Entre a cama de solteiro que dividia com o irmão e a cama de sua mãe, ele sentou. Respirou fundo. Apesar da ansiedade, queria curtir cada momento. Abriu o zíper com cuidado. Tirou caderno, livro, estojo. Ele apareceu: brilhante aos seus olhos. Gigante enfiou o braço, sacou com cuidado o motivo de sua euforia. Ficou olhando, admirado. Nunca tinha visto um daquele tão de perto. "Será que mostro pro Ju? Não, ele vive falando dessa 
parada, vai querer tomar de mim. Ou vai falar pra mãe que eu peguei de alguém. Apesar de que a mãe não ia acreditar. Uma pelo meu tamanho. Outra, que ninguém perde um brinquedo desse e deixa quieto. Eu vou mostrar nada não. Vou deixar muquiado, escondido. Meu segredo".

Gigante alisava o brinquedo. Observava o desenho, as formas as cores. Além do gatilho, o que mais lhe chamava a atenção era o cano longo, comprido, que havia sobre a parada. Prateado, lustroso. Tinha um descascado aqui e ali, mas sim: era novo. Apontou o cano na direção do seu rosto. Apertou o olho esquerdo e foi aproximando o direito dentro do buraco. Estava escuro. Cheirou. "Será que ainda tem alguma coisa aí?", pensou. Passou o dedo, olhou de novo. Nem percebeu que o seu polegar estava parado, dedo apoiado sobre o gatilho do objeto. Notou menos ainda a chegada do irmão que estranhando o comportamento do "mais novo" durante toda a manhã, chegou de fininho, nas pontas dos pés na porta do quarto. Abriu a porta com tudo e gritou:

- Quê que cê tá escondendo hein ô, muleque!

Gigante se assustou, apertou o pequeno gatilho com força, que disparou:

- Sguiiiiiiiiiiiiiiiiiiiiiiiiiiish!

Ainda havia água no reservatório do caminhão de bombeiro. Gigante ficou com a cara toda molhada. $\mathrm{O}$ irmão quase se mijou de tanto rir do susto que o irmão levou e da cena. Só parou quando viu o quanto da hora era o brinquedo. Tinha sirene, buzina e até uma escada Magirus, igualzinho ao caminhão de verdade que eles viram quando eram bem pequenos e, na sintonia que só os gêmeos possuem ficaram ambos hipnotizados com o caminhão e sua potência, o barulho que fazia ao trafegar e a sua saga: salvar pessoas. Aquele brinquedo era tão vivo, tão fresco em suas memórias. Carecia de dono e atenção, principalmente pelos detalhes de cores, luzes e faróis, além, é claro, do caninho longo, prateado e moldável, que servia como mangueira retrátil.

De alma lavada, Gigante nem brigou com o irmão pelo susto. Colocou o brinquedo em baixo do braço e foi pra rua brincar. Estava feliz. O caminhão estava funcionando. Era quase novo.

(CIRÍACO, Rodrigo. Um novo brinquedo. In: ANACAONA, Ana (org.). Eu sou favela. São Paulo: Nós, 2015) 


\section{Anexo B - Diários de Leitura selecionados para análise}

Os Diários de Leitura estão aqui dispostos da seguinte maneira: primeiro haverá digitalização do Diário em sua forma original, como produzido pelo aluno, em seguida, haverá a digitação dos textos produzidos pelos alunos. Na digitação, há algumas pequenas modificações visando estabelecer um sentido mais claro daquilo que o aluno queria dizer, tais modificações são, em sua grande maioria, inserção de elementos de pontuação. Quando a modificação se tratar da inserção de palavras omitidas, tais inserções virão em itálico. Os nomes de alunos mencionados nos Diários também foram retirados, visando preservar a identidade de cada um dos participantes. 
Diário de Leitura $\mathrm{N}^{\circ} 1$, aluna Antígona

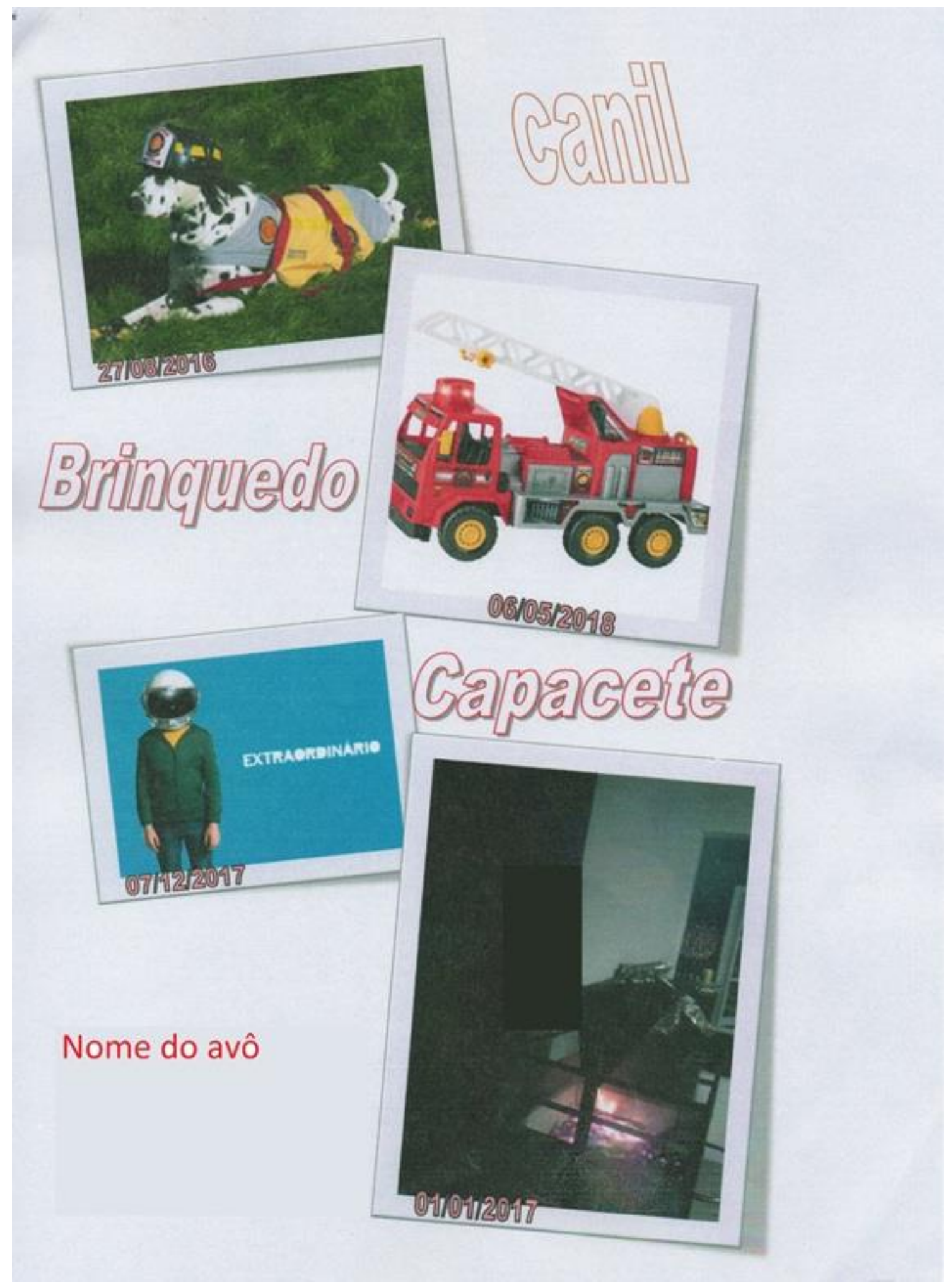


Qvonde lu comerai a ler, me lembrie do fil. me extonordimário, poer lle fer mascido com difi. culdodes de desemolumenta assim como Cuglle, a persangem da pilme, entäa lu umogines a "gigonte" cama a luglle.

Ac meic de teocto me sunta muito

complusa, porque en ainda nöo tinka sentido moda de especial l até entöa nó timba un conventrode a lastaste para entender a moGira de tonta alegria, mas entóce un li lussa parte de narte ande digia que le fovia in. comtrode a lerinquada, e enterndi a parque de tonta eufaria pais me lembir que fombeín sour assion saempre que encontere, 80 somhe, compre etc... alguma caisa, a onsiedode tama conta de mim, e a vantode de contar parar tados.

Ne pimal de teocta, já ustova curiaras para saber que lrimquede era aquele para a mimina Picar téa alegre. Quonde en descalori a que era. er. Piqui tipo mona vace picaw debse jeito par um cominkö de lamlecirce?" mas denpois de um tempa ler me lembir de duas caisass, primue ras era um lerinquede e soenda urm lrimqueda é usprial e legal de qualquer farmas, e a sigum188 da é que ine lembrei de quando mer

(2.) irmoü disse que preperia um cominfoo 21) De lombeira da que um videa gome

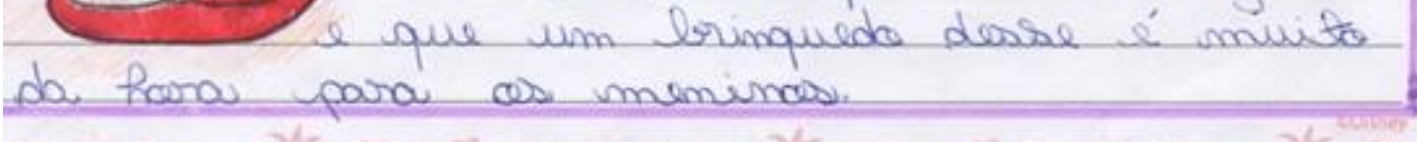
(i) i. Af 


\section{$800 \%$}

Cosse negácice de lomberros une pleg lembrar tamleím da "vmew ova", uño era de songue mas ura de curocpar a carormTa mana que saudade, me lombrei dele porque teve umas vig que lle lenow eur e mew prima na ligar ande as brombeiros ficom treinom ... e poi mui to louca essal dia, lá é marorilfosa, lle me disbe que me levaria lá de unove para combeor a ismil parquê quonda a gente fai mäa dew para ver, e... en plu mas impeligmente nōo com le, le se pai ontes desbe relle ocan. Ever

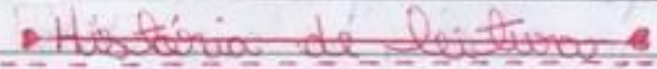

No uncontoro de Ristária de leitura, a que mais

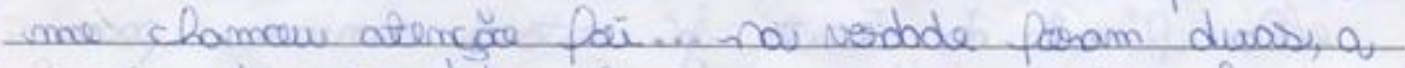
parte da sowudode, clara, ver que nuvis calegas de classe sientiram a sientiminto iqual as muw no care a saudode, e fambém do parte do Ferdóa que i aloge muite umportante, perceler também que dewemos praticar a arte derseper= docar as persaas.

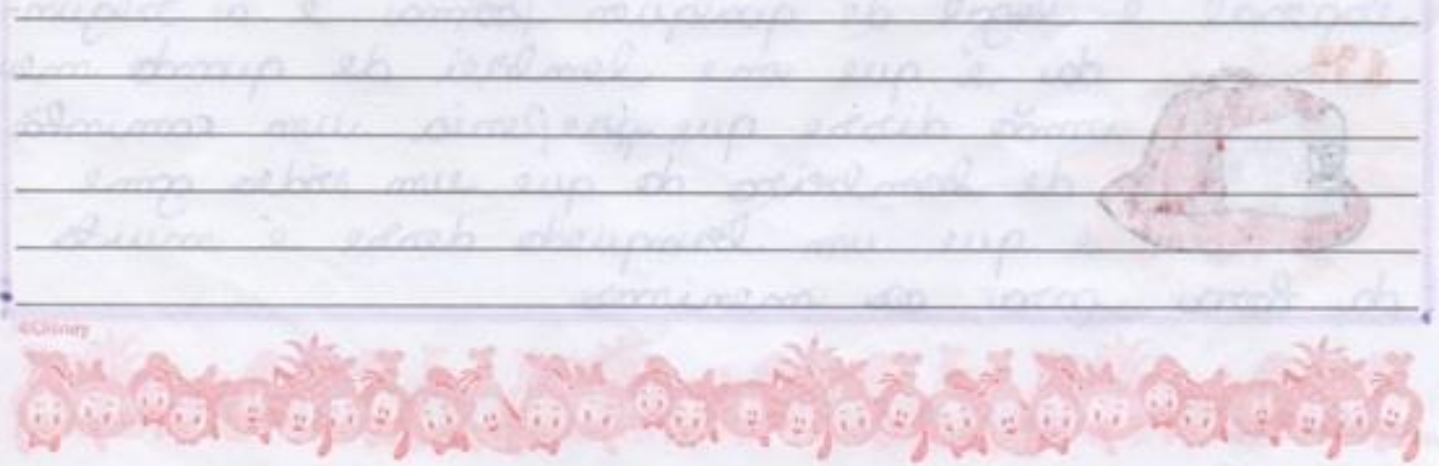




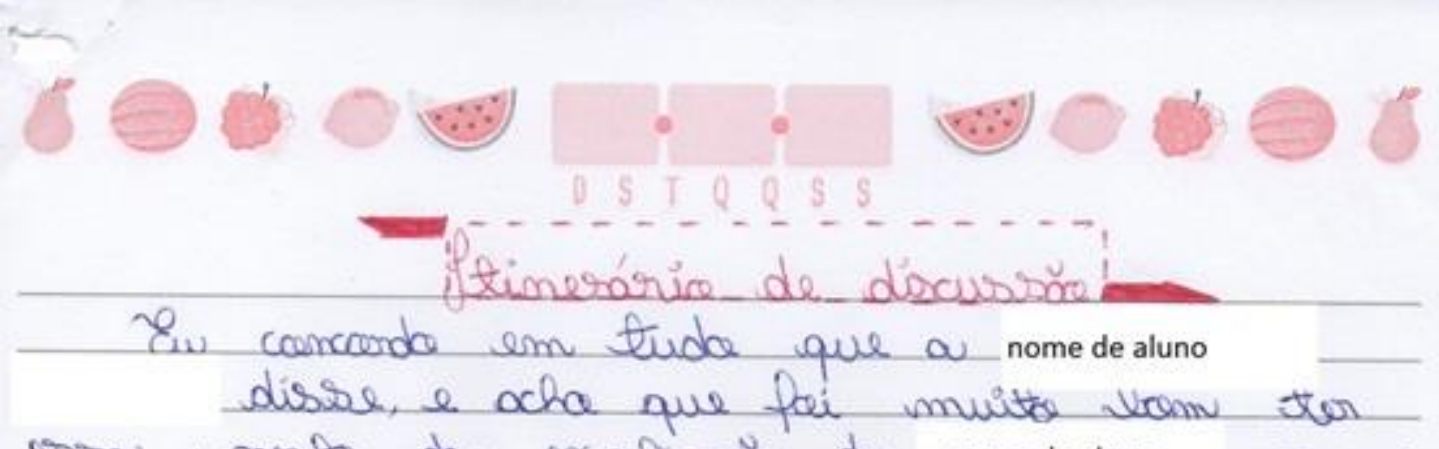

ususa uporte da explicorga da nomedealuno porque com uside lu combegui enocergar a tecta cam mais clarega, caisas que antes möe finta percelbida, conna par eocempla fuloger a gigonte de Porma erroda pelas palavas da marrodor a náa pelas atifudes do perbonogem. Cicha que muitos que lerom a terta teve wim juloganento ruim salere a giognde, par lle "mäa saer um form alune" e pelas referincias que a autor pas pra as leitoros orrditarem que a comisnhöo de fiombeiras seja uma arma, por exemplo na hora que estóce carocterisonde a lrimqueda. Fala de ga. filfo, de come l fambém a verlese sacar. mas quase ninguém viw a comportamente

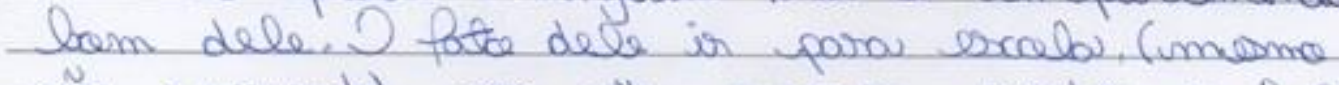

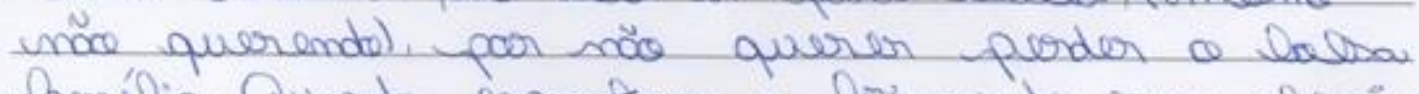

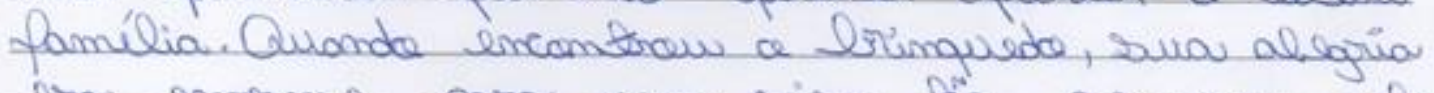
era encerme parar una coisa fía plquema, plo lotinguede lem lisar a heraísmo.

Cicke que a derriva parte do diaria fai una das unelfoeres, porque mesume lew e uner us caleopss lenda a teotto, só com as palowias da

nomede aluno que lu comblgui ver as caisass nutidas, causas que até entor lus nö timpa percebide. Nöe timpa pencelide em comce a idea lagia está, presenste na mimpa vidas. 


\section{0

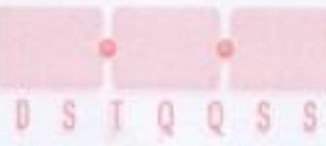 \\ * Ltistánia de convivencia $\rightarrow$}

Eu gostei muite da atividode pela fato de lu conseguir falar com meus calegas, coisas que noo comsiog com meus país, comos par exempla a assunta do "mew avi", é muito delicode lá em casa, entöo prefía nem tocar no arsurnte. mas unas sala lu consegui me alrir e falar tudo a que tinfa nantode. Fir muito loa essa experibincia, oha que as prafosuseres deviam sim passar isso para as alunas Porque vi "pesscas desinter essodas" lagende e gestanda da atividode. In too ocha que fai umuita nóa rá para nás, mas, para a prapesroora famlém. 


\section{Leitura Livre}

Quando eu comecei a ler, me lembrei do filme "Extraordinário", por ele ter nascido com dificuldades de desenvolvimento assim como Auggie, o personagem do filme, então eu imaginei o gigante como o Auggie.

No meio do texto me senti muito confusa porque eu ainda não tinha sentido nada de especial e, até então, não tinha me concentrado o bastante para entender o motivo de tanta alegria, mas então eu li essa parte de novo onde dizia que ele havia encontrado o brinquedo, e entendi o porque de tanta euforia, pois me lembrei que também sou assim, sempre que encontro, ganho, compro etc. alguma coisa, a ansiedade toma conta de mim e a vontade de contar para todos.

No final do texto já estava curiosa para saber que brinquedo era aquele para o menino ficar tão alegre. Quando eu descobri o que era, eu fiquei "mano, você ficou desse jeito por um caminhão de bombeiro?", mas depois de algum tempo eu me lembrei de duas coisas, primeira: era um brinquedo e sendo um brinquedo é especial e legal de qualquer forma, e a segunda é que me lembrei de quando meu irmão disse que preferia um caminhão de bombeiro do que um vídeo game e que um brinquedo desse é muito da hora para os meninos.

Esse negócio de bombeiro me fez lembrar também do "meu avô", não era de sangue, mas era de coração e, caramba mano, que saudade, me lembrei dele porque teve uma vez que ele levou eu e meu primo no lugar onde os bombeiros ficam, treinam... e foi muito louco esse dia, lá é maravilhoso, ele me disse que me levaria lá de novo para conhecer o canil porque quando a gente foi não deu pra ver, e... eu fui mas infelizmente não com ele, ele se foi antes desse rolê acontecer.

\section{Histórias de Leitura}

No encontro de história de leitura, o que mais me chamou a atenção foi ... na verdade duas coisas, a parte da saudade, claro, ver que meus colegas de classe sentiram o mesmo sentimento igual o meu no caso a saudade, e também a parte do perdão, que é algo muito importante, percebi também que devemos praticar a arte de perdoar as pessoas. 
Itinerário de Discussão

Eu concordo em tudo que a (nome de aluno) disse, e acho que foi muito bom ter essa parte da explicação da (nome de aluno) porque com isso eu consegui enxergar o texto com mais clareza, coisas que antes não tinha percebido, como, por exemplo, julgar o Gigante de forma errada pelas palavras do narrador e não pelas atitudes do personagem. Acho que muitos que leram o texto teve um julgamento ruim sobre o gigante por ele "não ser um bom aluno" e pelas referências que o autor faz para os leitores acreditarem que o caminhão de bombeiro seja uma arma, por exemplo, na hora que estão caracterizando o brinquedo, fala de gatilho, do cano e também o verbo sacar.

Mas quase ninguém viu o comportamento bom dele. $\mathrm{O}$ fato dele ir para a escola, (mesmo não querendo), por não querer perder o bolsa família. Quando encontrou o brinquedo, sua alegria era enorme para uma coisa tão pequena, pelo brinquedo lembrar o heroísmo.

Acho que a terceira parte do diário foi uma das melhores, porque mesmo eu e meus colegas lendo o texto, só com a palavra da (nome de aluno) que eu consegui ver as coisas nítidas que até então eu não tinha percebido. Não tinha percebido em como a ideologia está presente na minha vida.

Histórias de Convivência

Eu gostei muito da atividade pelo fato de eu conseguir falar com meus colegas coisas que não consigo com meus pais, como por exemplo o assunto do "meu avô", é muito delicado lá em casa, então prefiro nem tocar no assunto. Mas na sala eu consegui me abrir e falar tudo o que tinha vontade.

Foi muito boa essa experiência, acho que os professores deviam sim passar isso para os alunos. Porque vi "pessoas desinteressadas" fazendo e gostando da atividade. Então acho que foi muito bom não só para nós, mas, para a professora também. 
Diário de Leitura $\mathbf{N}^{\circ} 2$, aluna Alice

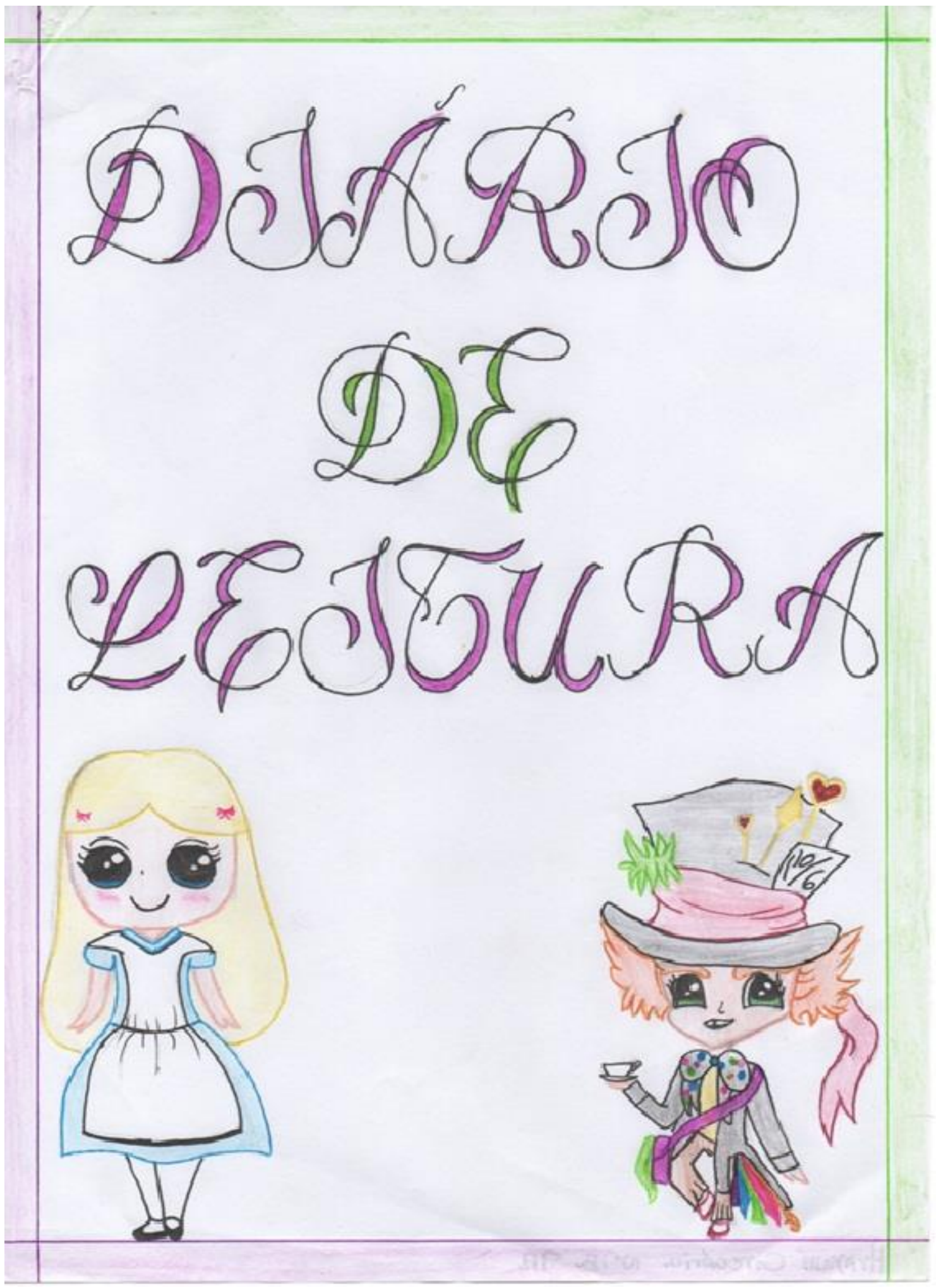




\section{- UM NOVO Brinquedo}

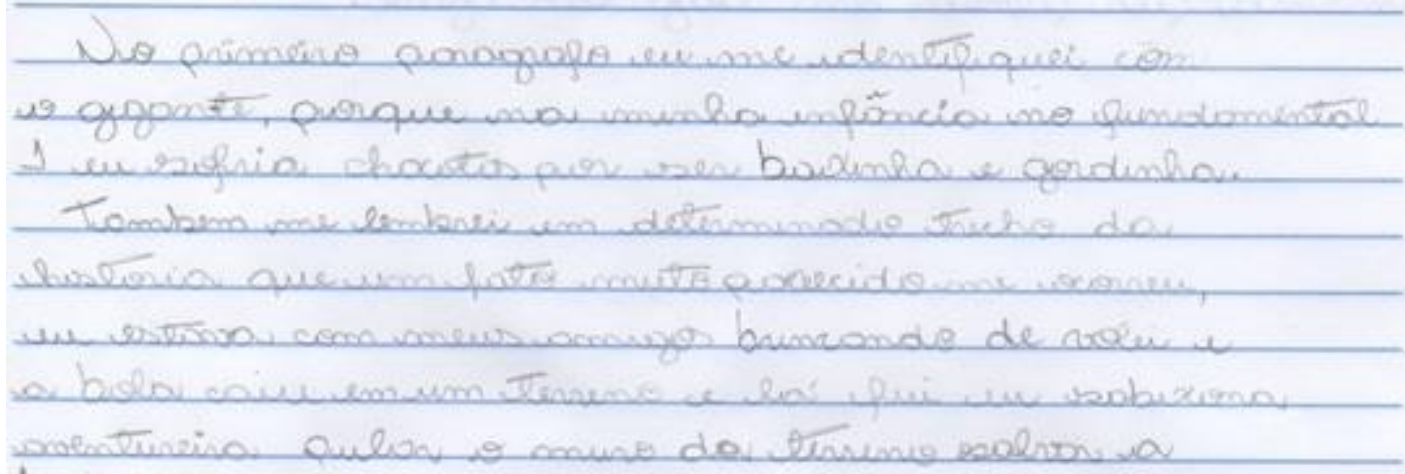

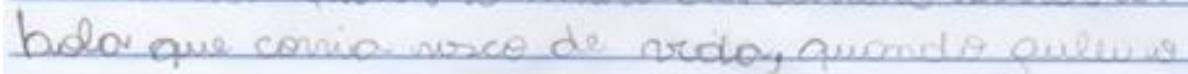

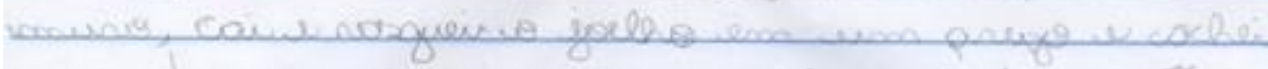

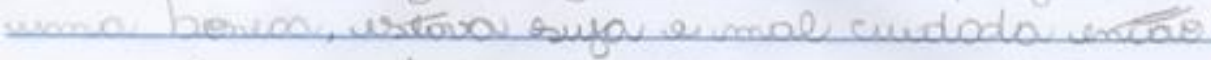

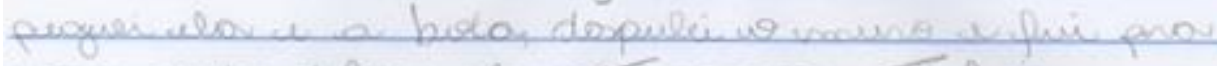

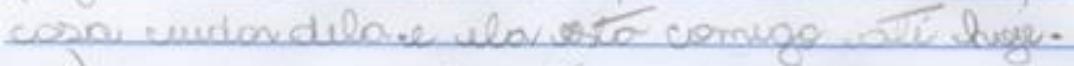

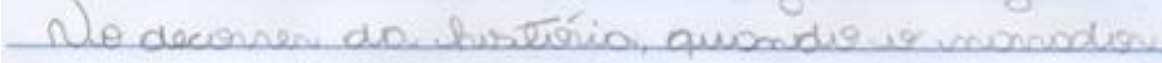

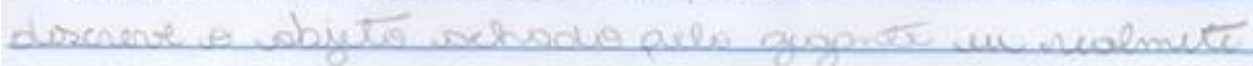

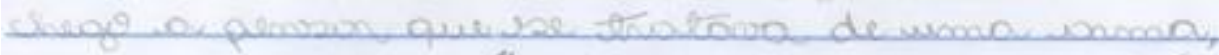

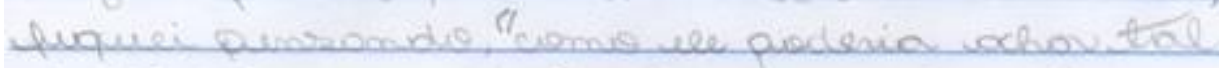

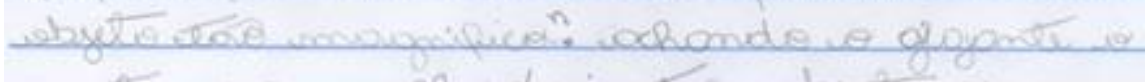

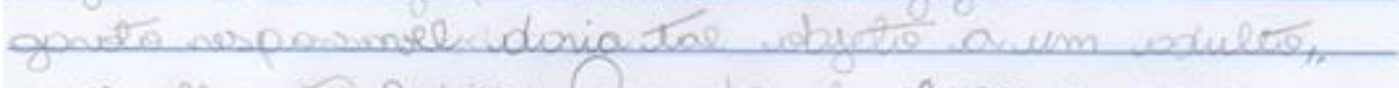

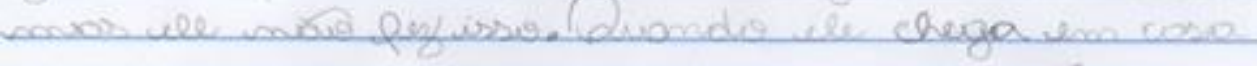
depuis de rasicu da oxola aepondo or mosterinsso

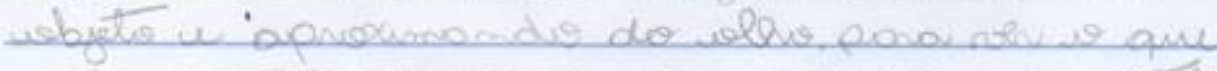

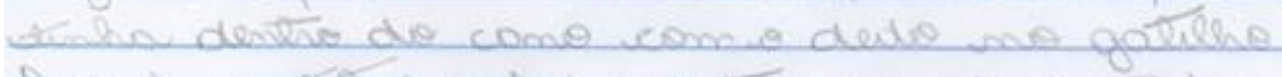

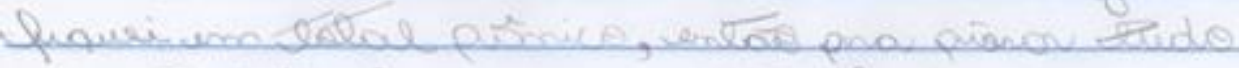

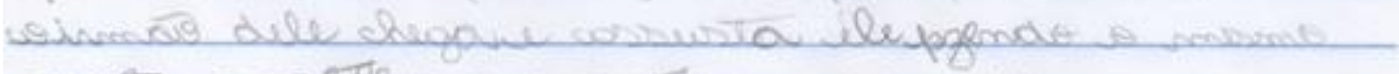

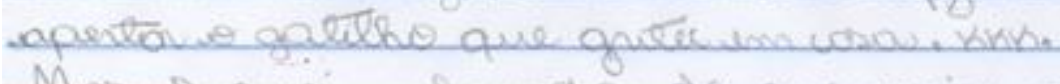

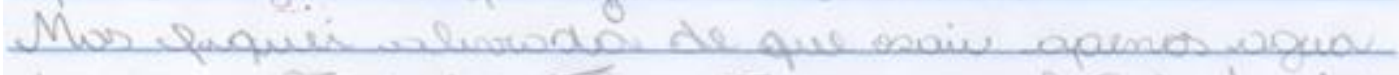

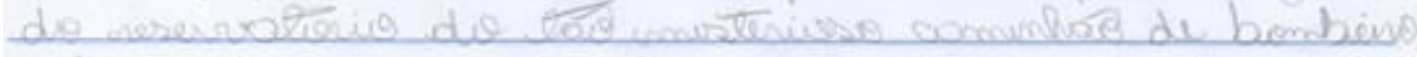

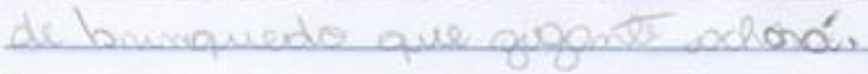




$$
\text { data (1) (1) (1) (5) (1) (7) }
$$

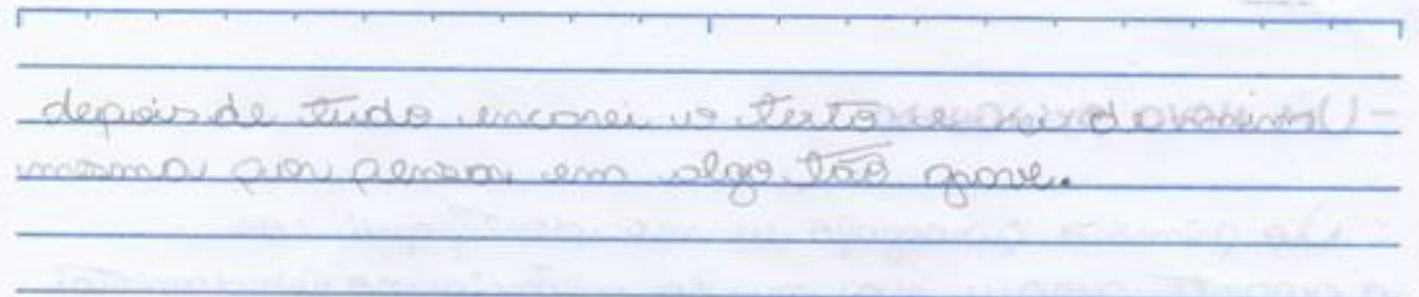




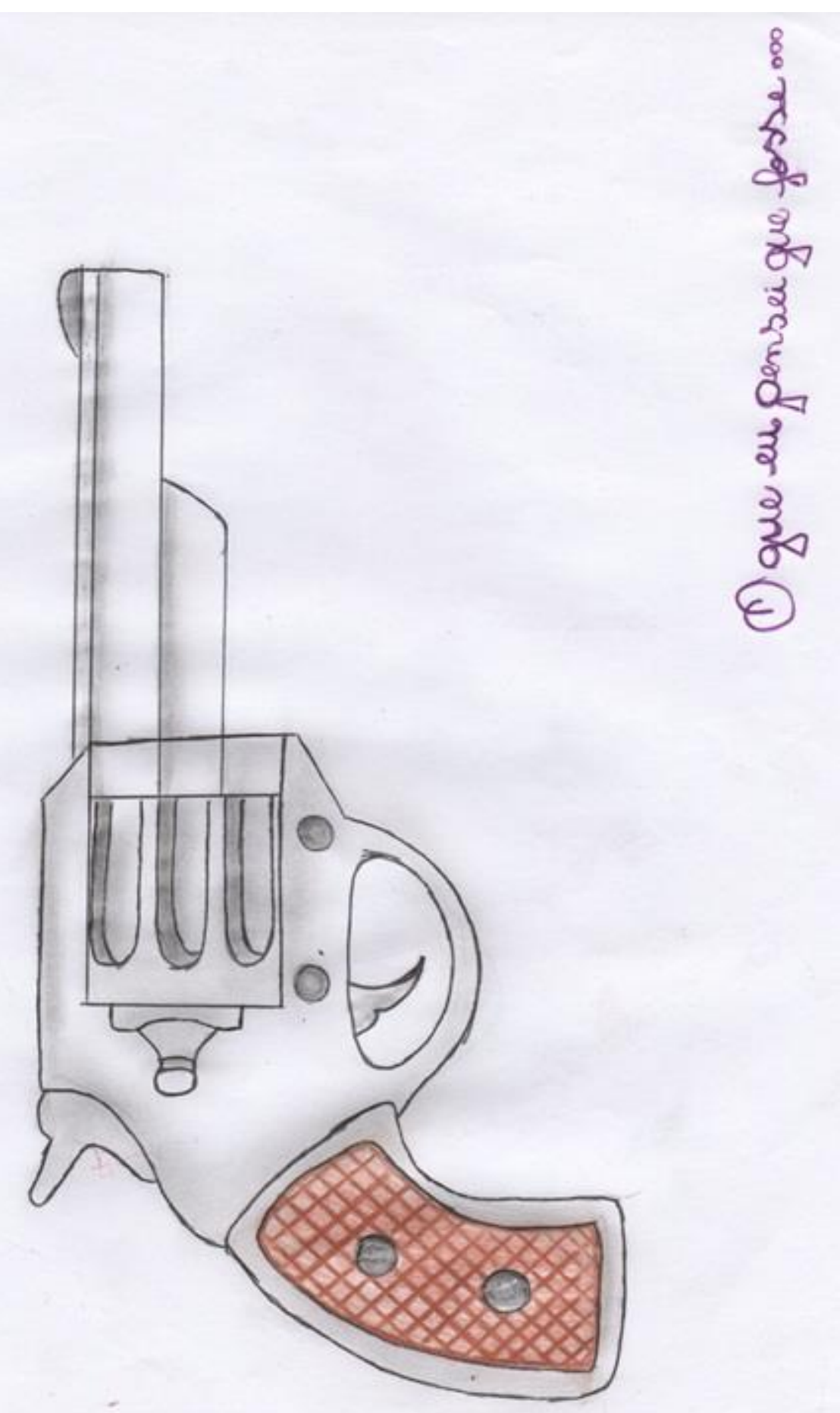




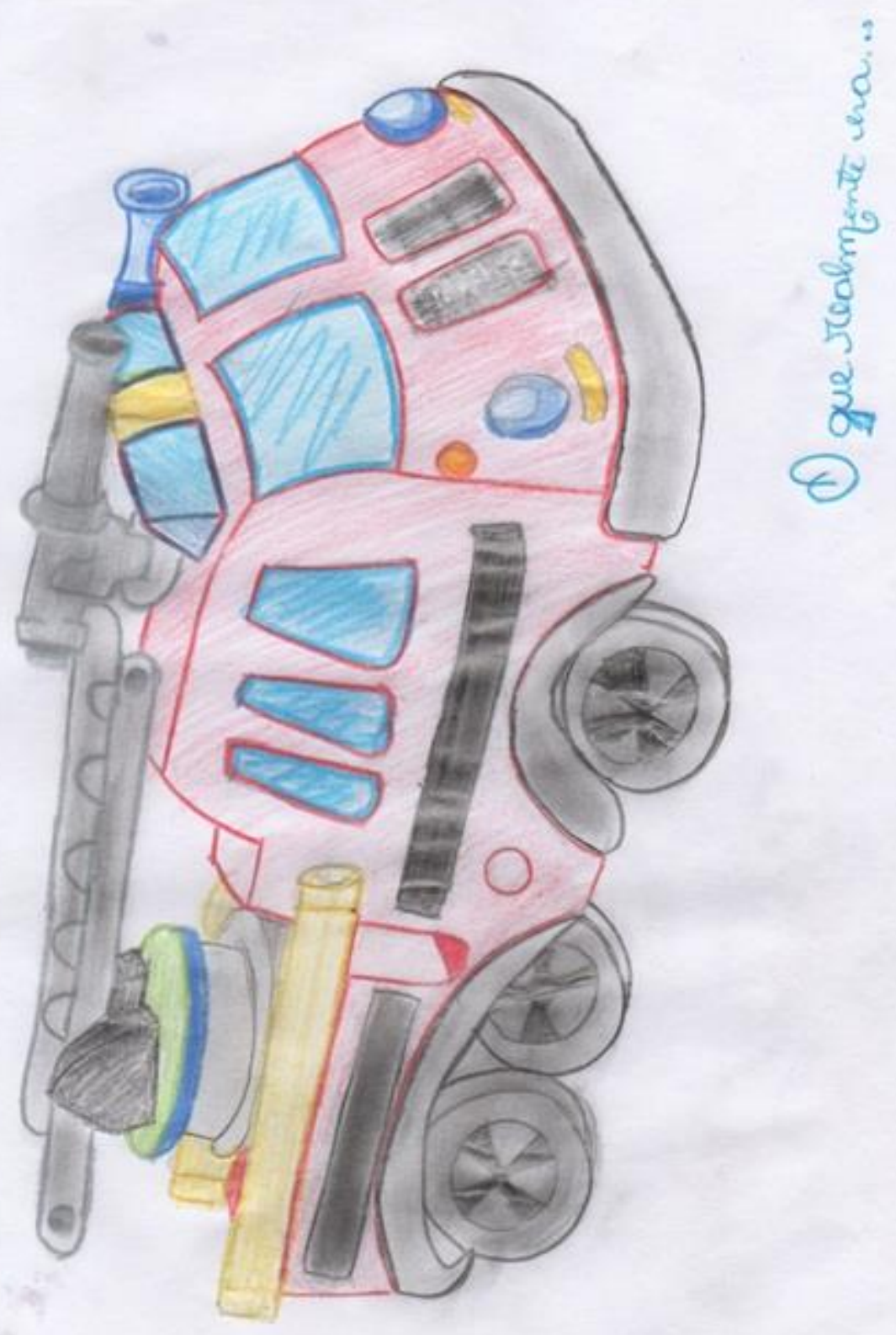




\section{Historias de Leitura.}

No encientro de lustrones de lecteria, eque

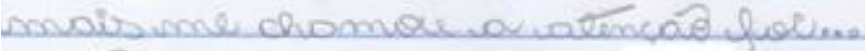

$$
\text { ineatio doa aluna D }
$$

Tirve a copocidode de spentifin usmusmos.

sentenertes que ela, a saudade de ter

pendido alguem thod impartante is un

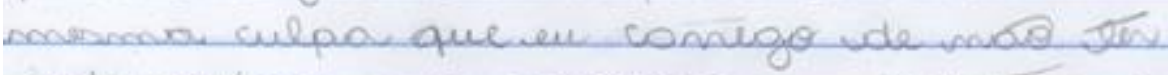

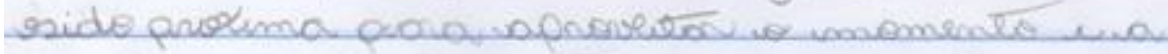

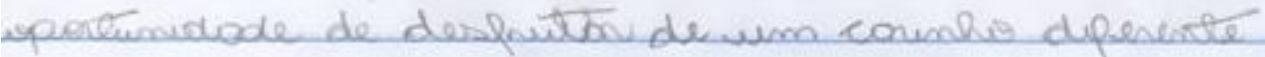

com a perdos do meu qudrimbo peacebe o

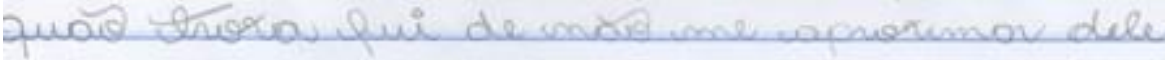

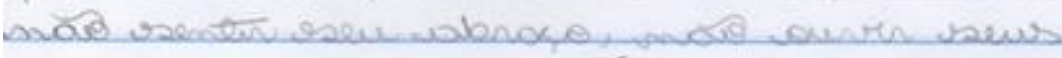

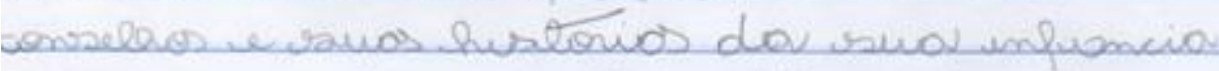
e e decionur do jurentude deley pecebo hoye in dig is quontes usse nane nplets e a alpa

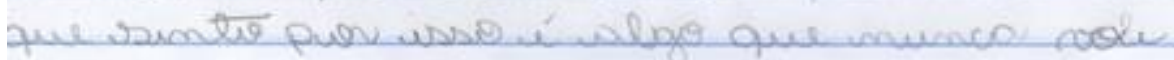
Tenon de dentro de wonim -

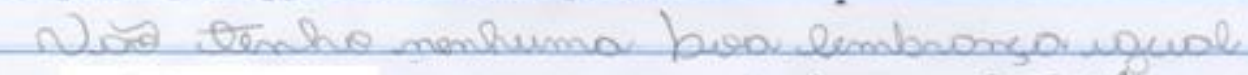

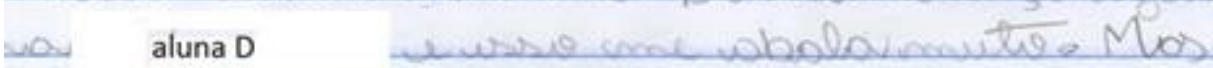
mermens depois de thide we suntes elu no

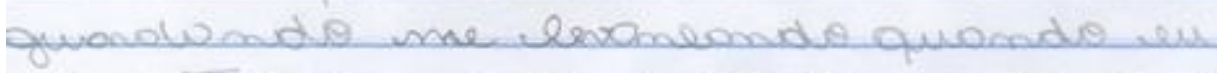

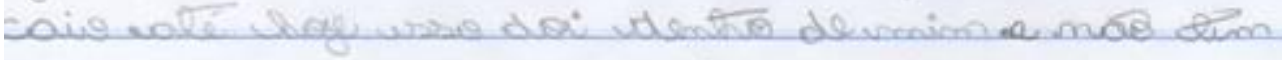

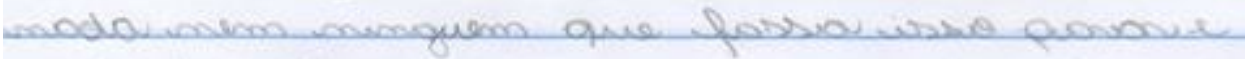
suin de mim. 


\section{- Itinerario de (1)iscucão}

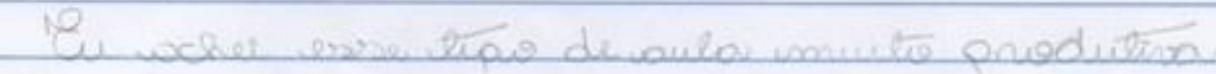

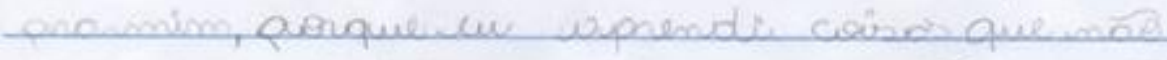

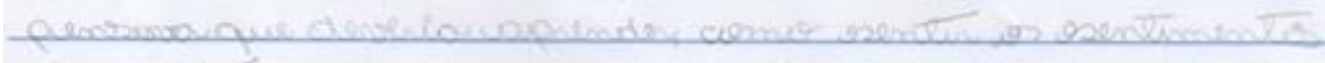

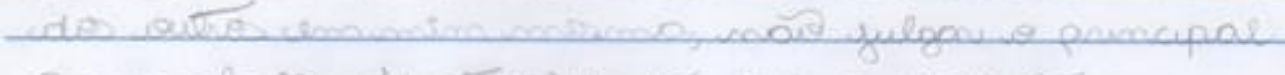

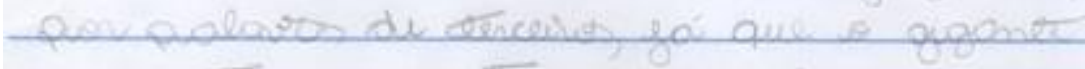

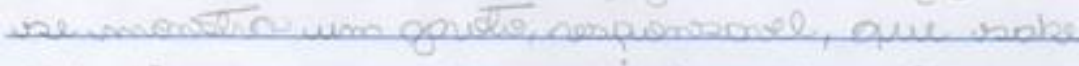

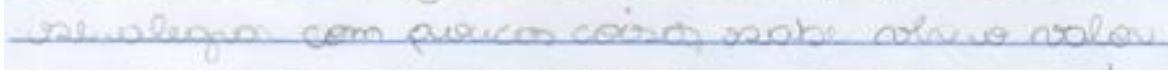

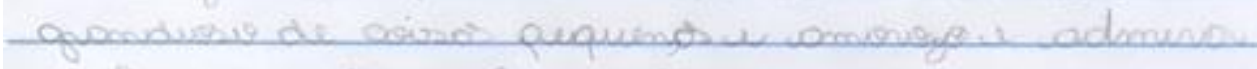

u Shencismo de atalion veíced.

If segumdis is unanodon ut gigonte uno

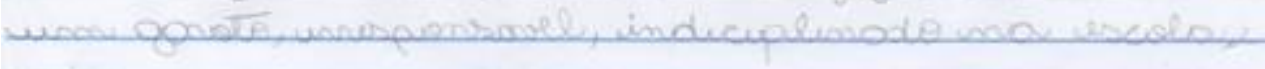

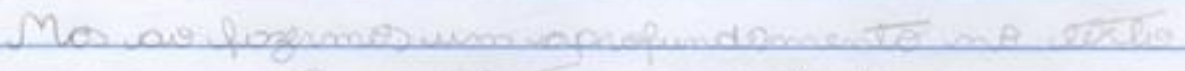

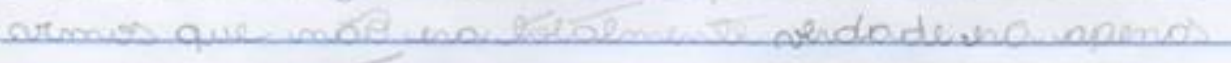

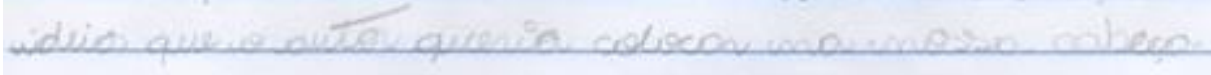




\section{Leitura Livre}

No primeiro parágrafo eu me identifiquei com o Gigante, porque na minha infância, no fundamental I, eu sofria chacotas por ser baixinha e gordinha.

Também me lembrei em determinado trecho da história que um fato muito parecido me ocorreu, eu estava com meus amigos brincando de vôlei e a bola caiu em um terreno e lá fui eu, sabichona, aventureira, pular o muro do terreno para salvar a bola que corria risco de vida, quando eu pulei o muro, cai e rasguei o joelho em um prego e achei uma boneca, estava suja e mal cuidada então peguei ela e a bola, despulei o muro e fui pra casa cuidar dela e ela está comigo até hoje.

No decorrer da história quando o narrador descreve o objeto achado pelo Gigante eu realmente cheguei a pensar que se tratava de uma arma, fiquei pensando "como ele poderia achar tal objeto tão magnífico". Achando o Gigante um garoto responsável, pensei que ele daria tal objeto a um adulto, mas ele não fez isso. Quando ele chega em casa depois de sair da escola, pegando o misterioso objeto e aproximando do olho para ver o que tinha dentro do cano com o dedo no gatilho fiquei em total pânico, então, para piorar tudo, o irmão dele chega e assusta ele fazendo o mesmo apertar o gatilho quase que eu gritei em casa. KKKK. Mas fiquei aliviada de que saiu apenas água do reservatório do tão misterioso caminhão de bombeiro de brinquedo que Gigante achara.

Depois de tudo, encarei o texto e ri de mim mesma por pensar em algo tão grave.

\section{Histórias de Leitura}

No encontro de histórias de leitura, o que mais me chamou a atenção foi... o relato da aluna "D", pois tive a capacidade de sentir os mesmos sentimentos que ela, a saudade de ter perdido alguém tão importante e a mesma culpa que eu carrego de não ter sido próxima para aproveitar o momento e a oportunidade de desfrutar de um carinho diferente, com a perda do meu padrinho percebi o quão trouxa fui de não me aproximar dele, não sentir seu abraço, não ouvir seus conselhos e suas histórias da sua infância e o decorrer da juventude dele, percebo hoje em dia o quanto isso me afetou e a culpa que sinto por isso é algo que nunca vou tirar de dentro de mim.

Não tenho nenhuma boa lembrança igual a aluna "D" e isso me abala muito. Mas mesmo depois de tudo eu sinto ele me guardando, me levantando quando eu caio. Até 
hoje isso dói dentro de mim e não tem nada nem ninguém que faça isso parar e sair de $\operatorname{mim}$.

Itinerário de Discussão

Eu achei esse tipo de aula muito produtiva pra mim, porque eu aprendi coisas que não pensava que ia aprender como sentir os sentimentos dos outros em mim mesma, não julgar o personagem principal por palavras de terceiros, já que o Gigante se mostra como um garoto responsável, que sabe se alegrar com poucas coisas, sabe ver o valor grandioso de coisas pequenas, é amoroso e admira o heroísmo de salvar vidas.

E segundo o narrador o Gigante era um garoto irresponsável, indisciplinado na escola.

Mas ao fazermos um aprofundamento no texto vimos que não era totalmente verdade, era apenas ideias que o autor queria colocar na nossa cabeça.

Histórias de Convivência

(A aluna não fez por ter faltado na aula de Histórias de Convivência) 
Diário de Leitura $\mathbf{N}^{\circ}$ 3, aluno Narciso

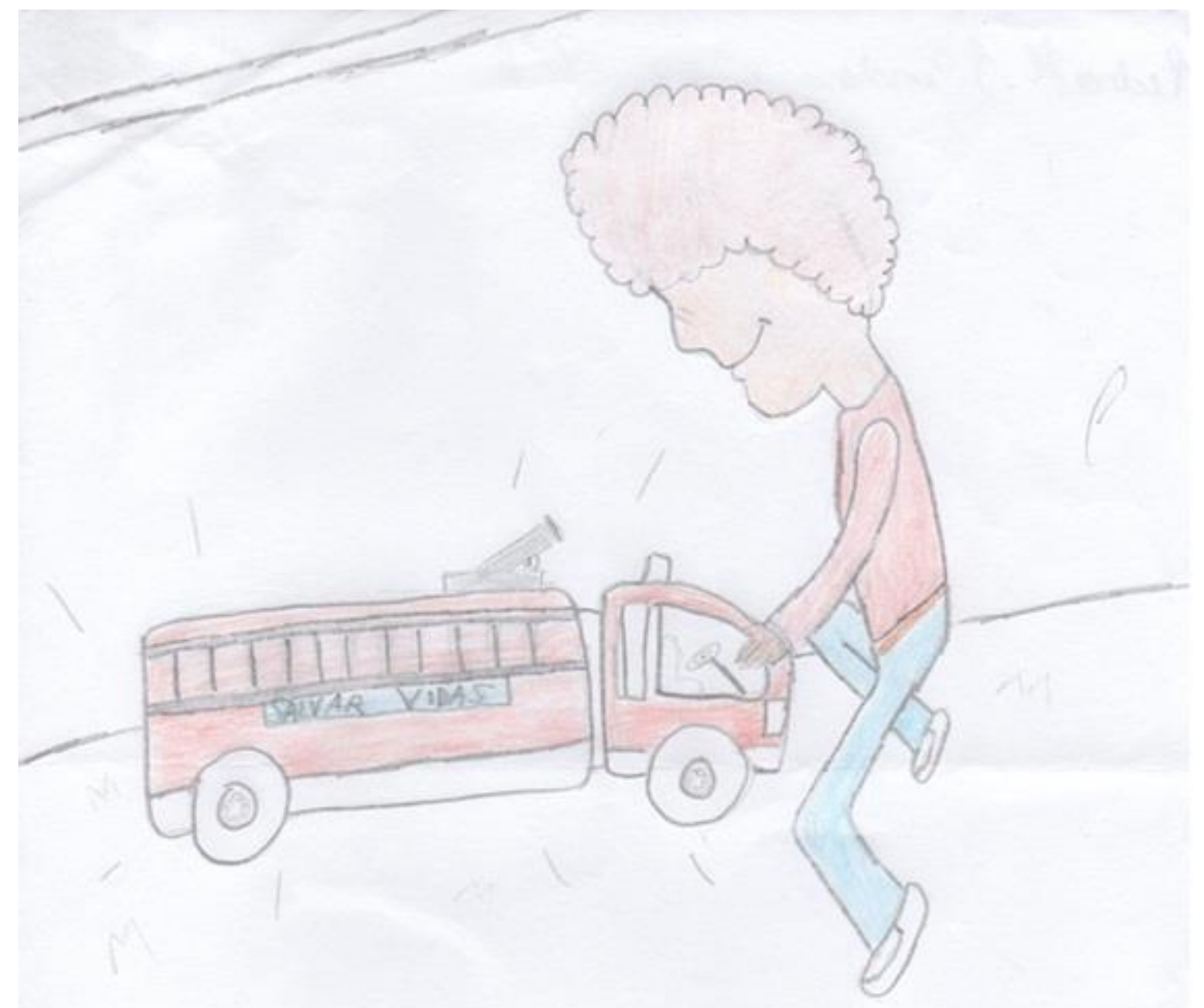

Trabalho de português 
175

Pome.

n

No comego dee texto pra min ele estavo bern engracado, un anao tentanda pular 6 invire "da escola. I texto estavo parecendo de comédic. Na perte que el Gigente feti merandars achei un fauca de sacanagen mas bern engeasads. Cucho que nunga ì una crianca fican taó felij os evchar un brinquedo, ate farea que gankas in

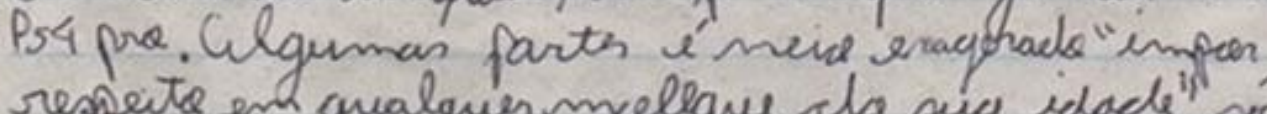
sespeita en qualquer mellque cla sua idade", sérise? peer sauso ell un biinquedo?

Gcha que esse qurato deve ter ticto unna infámeno difieie parce ele fuar feliz com un unvico bringuedo.

We farice en quando ganhei un $P_{52}$, piqua tèro felly que mä́ quehis tivan da caixa, mar conseguis domir, cen comen. Glgumes forter de terto en fensei imalício, en suchei gre seria mais checant, men só fer uno disteriona de en ancivo que cuboer un brincqueda. Testre noernal nado de main, bem tediante, só ce cornego que fer engraçado.

Hesterien de lectura

Sepeis de ounin dwernen historion de laituran en percebi que li ce tes to de forma errada, ms. une um brinquedo tío simpla deixcor a gigante felin, menno sendo sem valos, ele vie cropule 
176

caminhá de bombiracom ackmineróco. Lepeen de divernen histivies de lestura, percelt que und binquedo pede feng uno crience fele,

for semple que sejo.

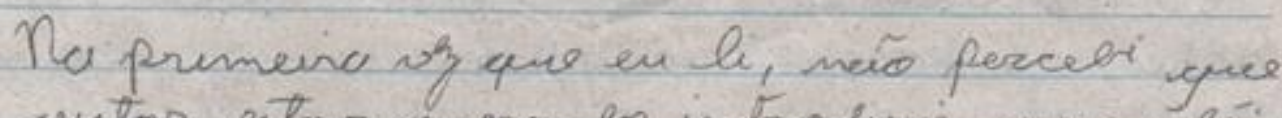
a curter estaro querendo introduzsi una waléis

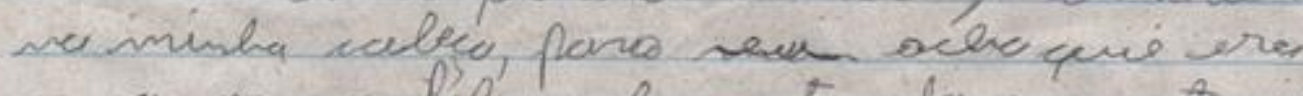
una cermo. Celes julopamento davo entendes que of eurceto iria micitar as flesseen com a

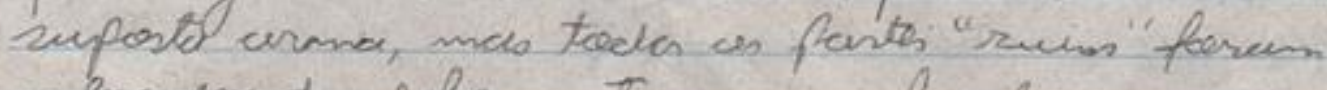
menciarides pelo cuitar, mes lencles con mas atencro, he tercte a clivernes fiteers dew es gereto nos irio fings ins.

Hesteric de combivencia

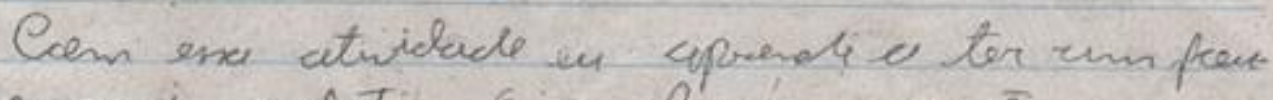
wa main enfatice. Em relerque $\mu$ senteinanto,

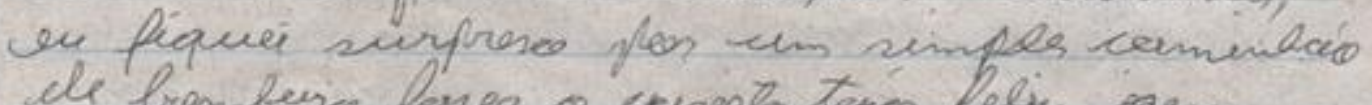
de brenbera forer a cureeto terco feliz, esern empetir cucabl exchardes un brinquicke belve. uprencli tamberm a len 4 teato moes "propunde. mente, sem Gulgan. uplemen feloque o nurvocken fela. 


\section{Leitura Livre}

No começo do texto, pra mim, ele estava bem engraçado, um anão tentando pular o muro da escola. O texto estava parecendo de comédia. Na parte que o Gigante foi merendar, achei um pouco de sacanagem mas bem engraçado. Acho que nunca vi uma criança ficar tão feliz ao achar um brinquedo, até parece que ganhou um Playstation 4 Pro. Algumas partes é meio exagerado "impor respeito em qualquer moleque da sua idade", sério? Por causa de um brinquedo?

Acho que esse garoto deve ter tido uma infância difícil para ele ficar feliz com um único brinquedo.

Até parece eu querendo ganhar um Playstation 2, fiquei tão feliz que não queria tirar da caixa, mal consegui dormir ou comer.

Algumas partes do texto eu pensei malícia, eu pensei que seria mais chocante, mas só foi uma história de um anão que achou um brinquedo. Texto normal. Nada de mais, bem tediante, só o começo que foi engraçado.

História de Leitura

Depois de ouvir diversas histórias de leitura, eu percebi que li o texto de forma errada, mesmo um brinquedo tão simples deixou o Gigante feliz, mesmo sendo sem valor, ele via aquele caminhão de bombeiro com admiração.

Depois de diversas histórias de leitura, percebi que um brinquedo pode fazer uma criança feliz, por mais simples que seja.

Itinerário de Discussão

Na primeira vez que li, não percebi que o autor estava querendo introduzir uma ideia na minha cabeça, para eu achar que era uma arma. Pelo julgamento, dava a entender que o garoto iria matar as pessoas com a suposta arma, mas todas as partes ruins foram mencionadas pelo autor, mas lendo com mais atenção, no texto há diversos fatores de que o garoto não iria fazer isso. 
Histórias de Convivência

Com essa atividade eu aprendi a ter um pouco mais de empatia. Em relação à sentimento, eu fiquei surpreso por um simples caminhão de bombeiro fazer o garoto tão feliz, sem empatia acabei achando um brinquedo bobo.

Aprendi também a ler o texto com mais "profundidade", sem julgar apenas pelo que o narrador fala. 
Diário de Leitura $\mathrm{N}^{\circ} 4$, aluno Epimeteu
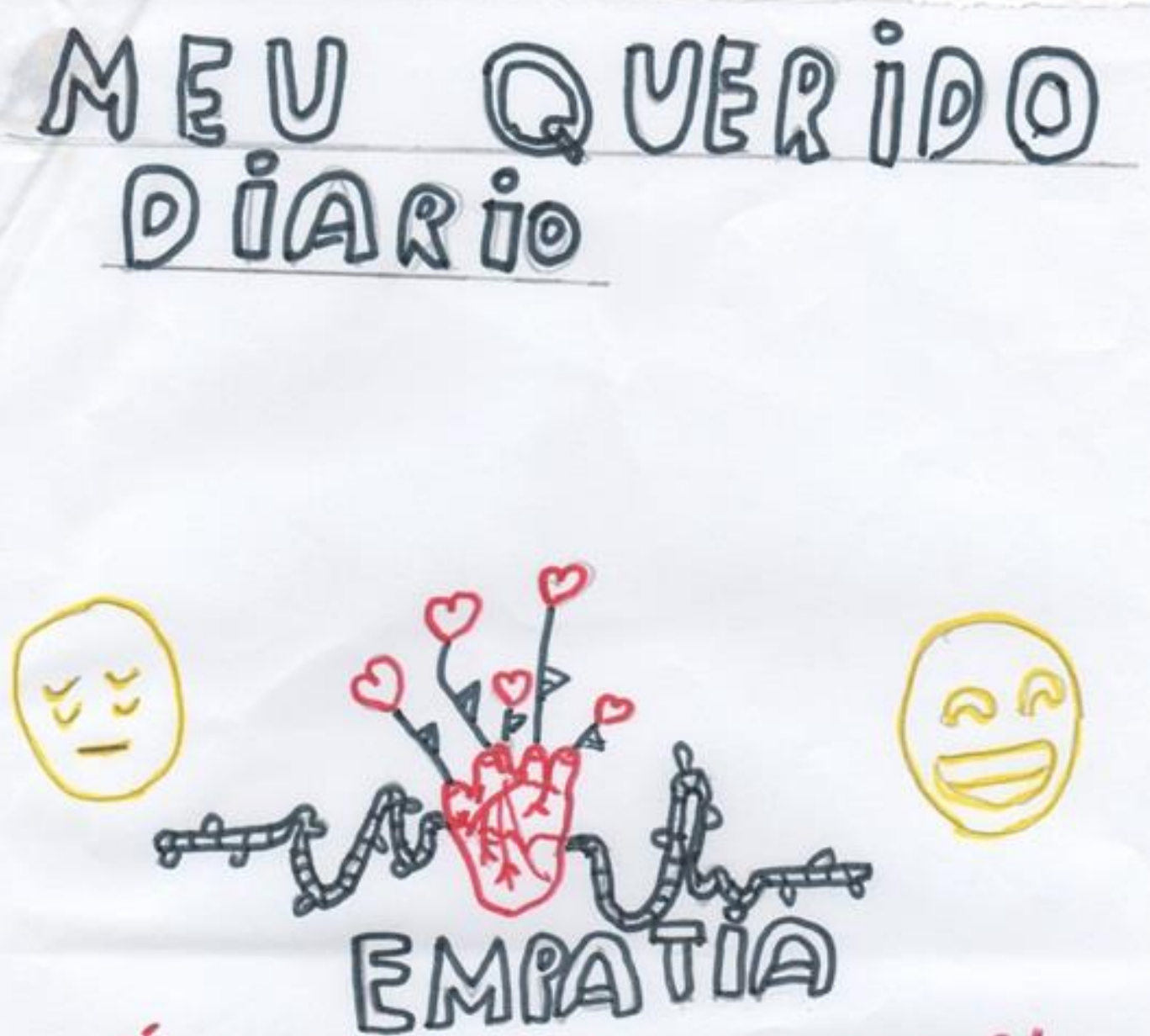

Equande nuấ deiva de nen Egsita derfoca a sen mabig i nent aquibs qual o neu procino sutá sentimot.

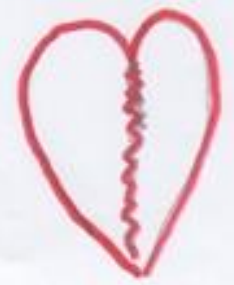




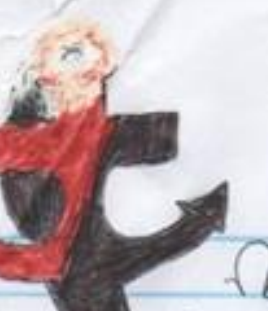

Dona lu fo Coneco lu achei que ia Ostender

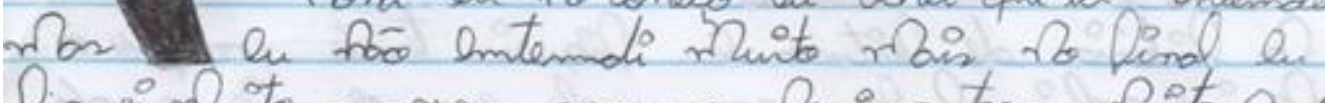
Diquei rninto surpresa porque o rlenine tra rlist amcis. o para lerimcar Com a Orimquedo doro lu ochei que -

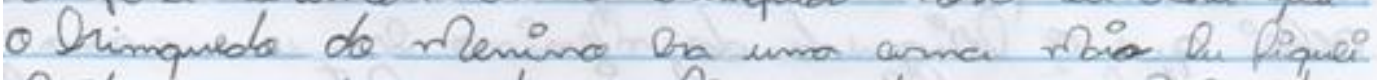
ruite encocionade quande ln li a parte que a vilenino tra. Com a brimquedo \& O dedo no gatilio hu ad i i que en tha ama rbin era una monqulina da corra de lom 8

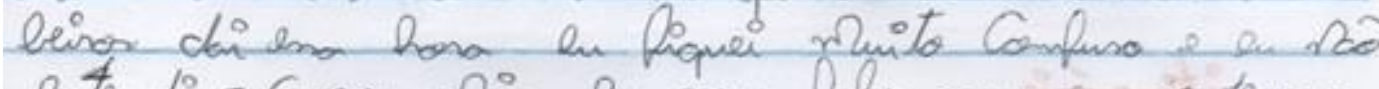
entendi a coseca rbin lu ram bolar oque en sienti no. Conecg, lu remti una Curiasidade rbins quande ln li ena frare, Cquande nouble oque ia parar a estudas de ma-

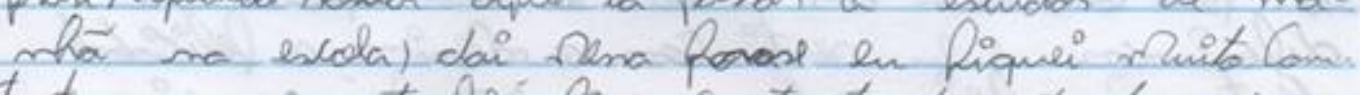
tente provou en tamben lica contemte de estudos de is, manka va escola e en fiquei lembramdo quande en era mais wemor lu timba achode lringue e en gostara tanto do Nen bringuede que en brui ela pora escala le ln $\sqrt{b 0}$ tana prentando a atenna una aula dai o profenor. rim l pegou vena hora en Gborri rluite depois lu bai entender o boto ruin \& a berm ol low erprestr a atenzo ma alla e no intervola lu boto rumie ño ter dado atemoo pro profener eter se entertida Com o Orinquedo e en fiquilion

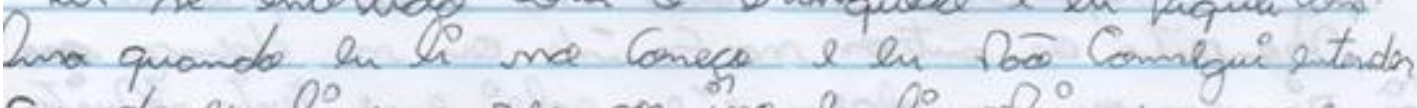
quando en li una rez por ino ln li mbir uno vey Pai ac que en entemcli e ln is Comeguir foger mikin. un pouco e sempre que en ador um erinquido bu

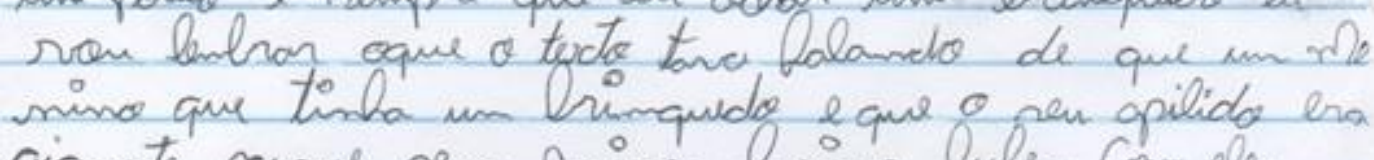
gigante porque sems amigos forziana lulem con ele. 


\section{(1)}

Distoria de Citura

Ib listória de leitura en Riquei triste porque o. demino sothia bulem porque ele era o whenon de sua turana por ino, en Diquei Nuito triste l lu ochei que a Eriquedo do nlenino lra una arma sefria tulen e toneren porque no texco bola que - rlemina tara Com a dedo no gatilia.

\section{itimeróros}

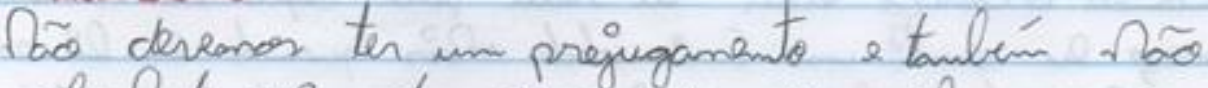

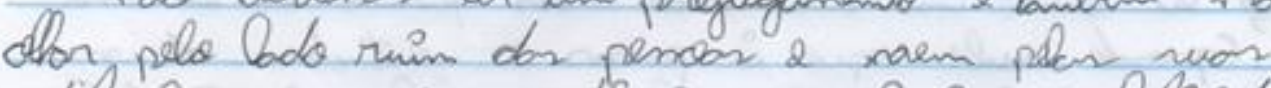
difezerregr of lu nenti con o menimo, a plicidode de ter um brinquede unoro e tandén me doi rer alguén sofremdo bulem au falos en buben en jó fir una rey com un dor weu melhore anigon en fali una Coina ruito desogrodariel l depois dino be Runca rbir folou Conigo e lu me anependi Nuito e, Runca dais en rou hager bulem con Ninguéno

$$
\text { Qistoria de Comriruencia }
$$

En gostei de les runito ene terto e en aprench

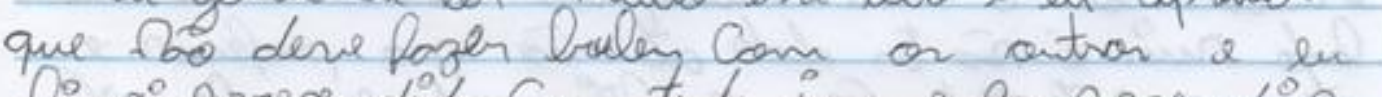
Riquei arrependido Con terdo ino e ln aprendia orepiter as atror ma riqueea on ma polresa e'en achei esal texto inivito nana e àuando en tiver un filbo ro eminar ell a respitan or outror. 


\section{Leitura Livre}

Nossa eu no começo eu achei que ia entender mas eu não entendi muito mais no final eu fiquei muito surpreso porque o menino tava muito ansioso para brincar com o brinquedo novo eu achei que o brinquedo do menino era uma arma mais eu fiquei muito emocionado quando eu li a parte que o menino tava com o brinquedo e o dedo no gatilho eu achei que era uma arma mais era uma mangueira do carro de bombeiro daí essa hora eu fiquei muito confuso e eu não entendi o começo mais eu vou falar o que eu senti no começo eu senti uma curiosidade mais quando eu li essa frase (quando soube que ia passar a estudar de manhã na escola) daí nessa frase eu fiquei muito contente porque eu também fico contente de estudar de manhã na escola e eu fiquei lembrando quando eu era mais menor eu tinha achado um brinquedo e eu gostava tanto do meu brinquedo que eu levei ele pra escola e eu não tava prestando atenção na aula daí o professor viu e pegou nessa hora eu chorei muito depois eu fui entender o lado ruim e o bom o bom é prestar atenção na aula e no intervalo eu brincar com o meu brinquedo novo e o meu lado ruim é não ter dado atenção pro professor e ter se entertido com o brinquedo e eu fiquei confuso quando eu li no começo e eu não consegui entender quando eu li uma vez por isso eu li mais uma vez foi aí que eu entendi e eu ia conseguir fazer mais um pouco e sempre que eu achar um brinquedo eu vou lembrar o que o texto tava falando de um menino que tinha uma brinquedo e que o seu apelido era Gigante porque seus amigos faziam bulem com ele.

\section{Histórias de Leitura}

$\mathrm{Na}$ história de leitura eu fiquei triste porque o menino sofria bulem por que ele era o menor da sua turma por isso, eu fiquei muito triste e eu achei que o brinquedo do menino era uma arma e eu também achei que ele ia se matar porque ele sofria bulem, e também porque no texto fala que o menino tava com o dedo no gatilho.

\section{Itinerário de Discussão}

Não devemos ter um prejulgamento e também não olhar pelo lado ruim das pessoas e nem pelas suas diferenças e eu senti com o menino a felicidade de ter um brinquedo novo e também me doi ver alguém sofrendo bulem ou falar em bulem eu já 
fiz uma vez com um dos meu melhores amigos eu falei uma coisa muito desagradável e depois disso ele nunca mais falou comigo e eu me arrependi muito e nunca mais vou fazer bulem com ninguém.

Histórias de Convivência

Eu gostei de ler muito esse texto e eu aprendi que não deve fazer bulem com os outros e eu fiquei arrependido com tudo isso e eu aprendi a respeitar os outros na saúde ou na doença na riqueza ou na pobreza e eu achei esse texto muito massa e quando eu tiver um filho vo ensinar ele a respeitar os outros. 